\title{
Ground-Water Resources of Kings and Queens Counties, Long Island, New York
}

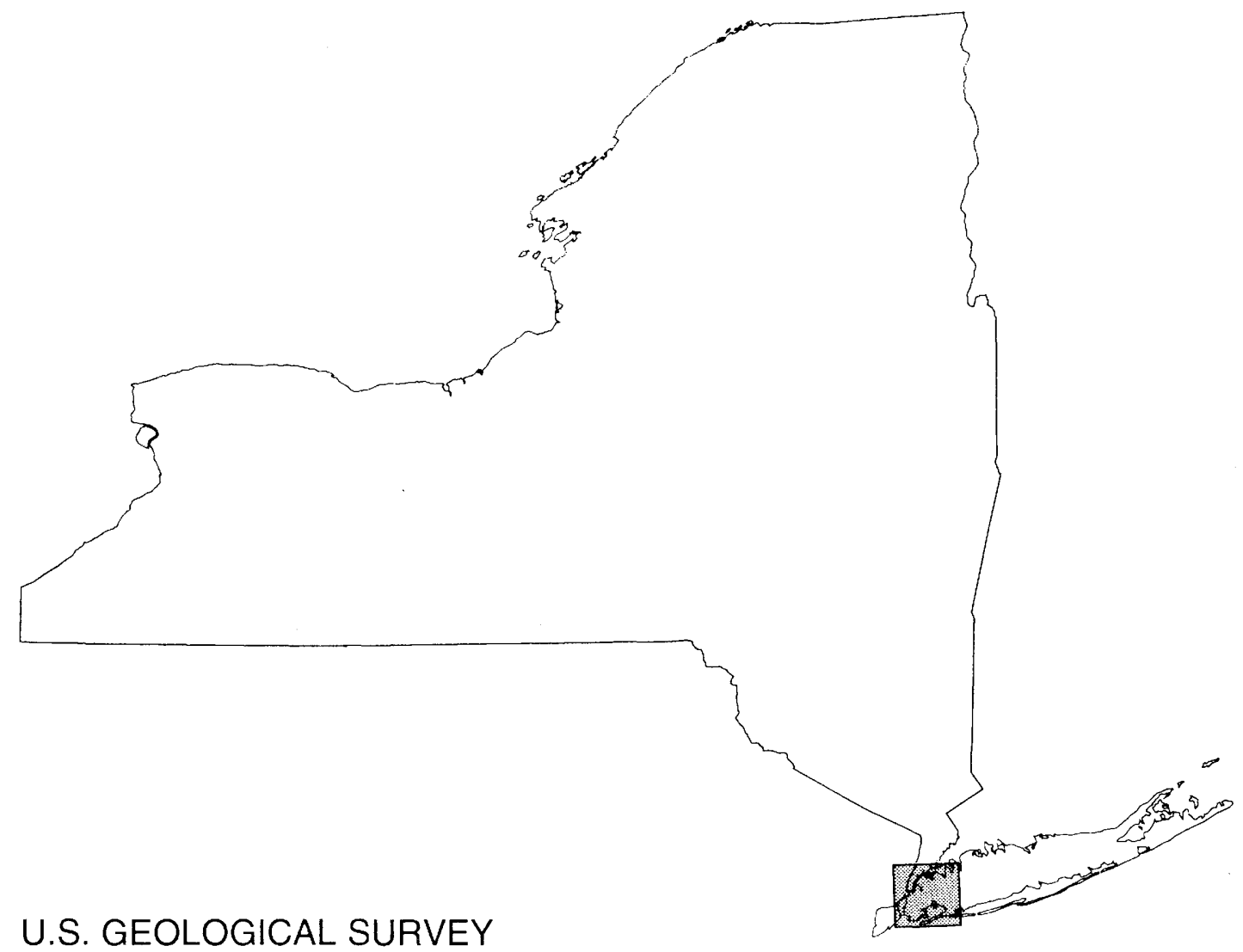

Open-File Report 92-76

Prepared in cooperation with

NEW YORK CITY DEPARTMENT' OF

ENVIRONMENTAL PROTECTION

and

NEW YORK STATE DEPARTMENT OF

ENVIRONMENTAL CONSERVATION

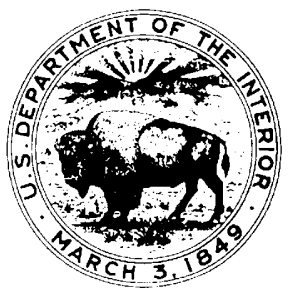





\section{GROUND-WATER RESOURCES OF KINGS AND QUEENS COUNTIES, LONG ISLAND, NEW YORK}

By Herbert T. Buxton and Peter K. Shernoff

\section{U.S. GEOLOGICAL SURVEY}

Open-File Report $92-76$

Prepared in cooperation with

NEW YORK CITY DEPARTMENT OF ENVIRONMENTAL PROTECTION and NEW YORK STATE DEPARTMENT OF ENVIRONMENTAL CONSERVATION

Albany, New York 


\section{DEPARTMENT OF THE INTERIOR}

BRUCE BABBIT, Secretary

U.S. GEOLOGICAL SURVEY

Gordon P. Eaton, Director

For additional information write to:

U.S. Geological Survey 2045 Route 112

Coram, N.Y. 11727
Copies of this report may be purchased from:

U.S. Geological Survey Earth Science Information Center P.O. Box 25286 Denver, CO 80225 


\section{CONTENTS}

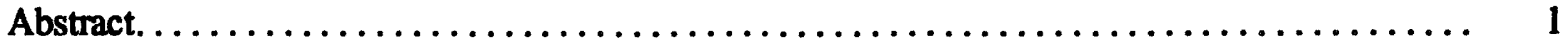

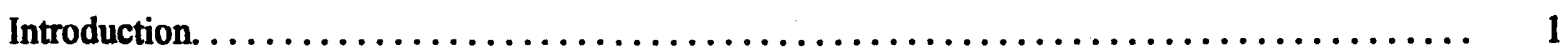

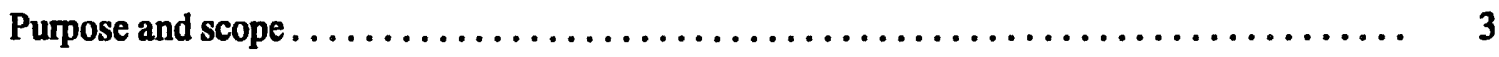

Acknowledgments.......................................... 3

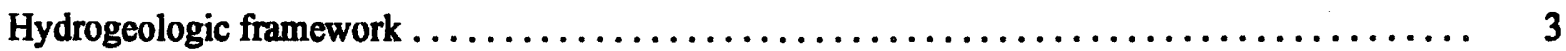

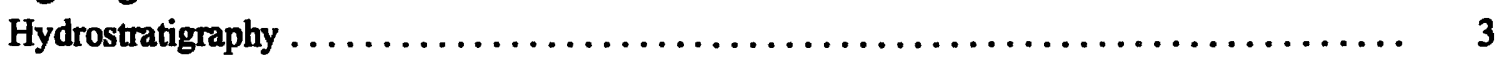

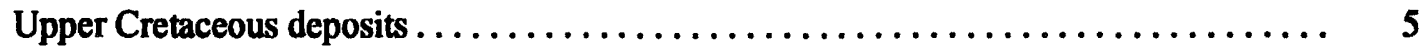

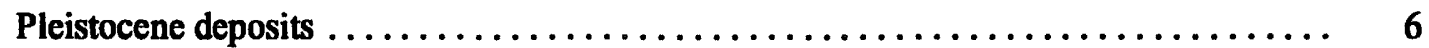

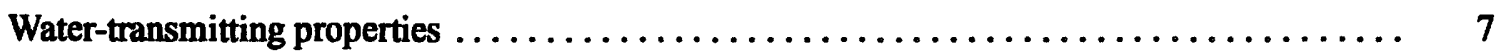

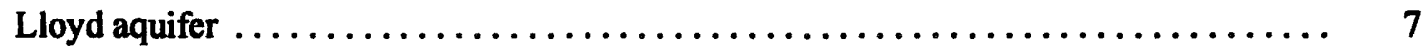

Jameco-Magothy aquifer............................. 7

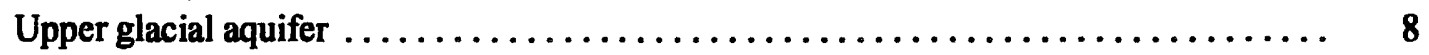

Predevelopment hydrologic conditions $\ldots \ldots \ldots \ldots \ldots \ldots \ldots \ldots \ldots \ldots \ldots \ldots \ldots \ldots \ldots \ldots, \quad 8$

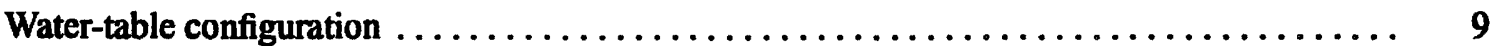

Water budget. .............................................. 11

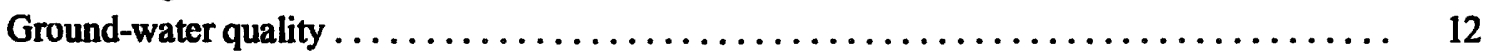

Effects of urbanization on the hydrologic system $\ldots \ldots \ldots \ldots \ldots \ldots \ldots \ldots \ldots \ldots \ldots \ldots \ldots$

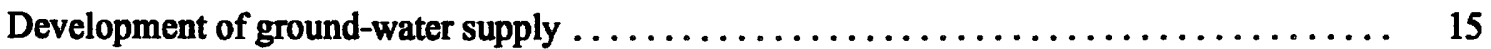

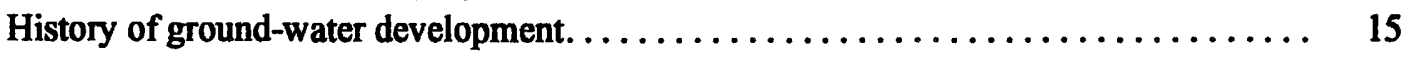

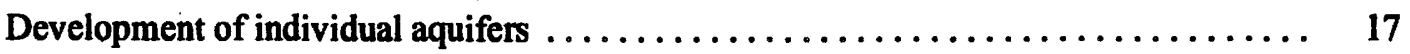

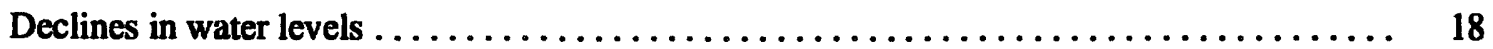

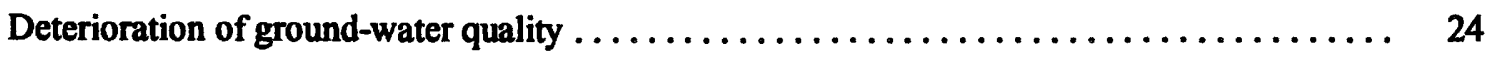

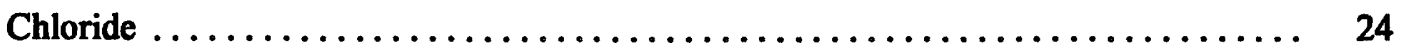

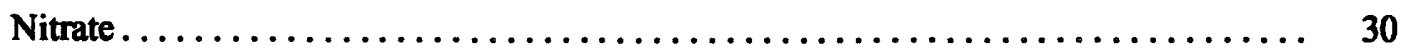

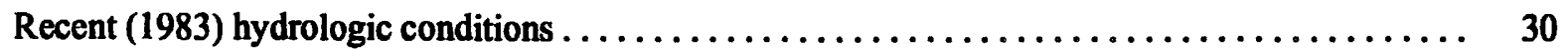

Water-table and potentiometric-surface altitudes. . . . . . . . . . . . 30

Water-table configuration. ................................ 31

Potentiometric surface of the Jameco-Magothy aquifer $\ldots \ldots \ldots \ldots \ldots \ldots \ldots \ldots . . \ldots \ldots$

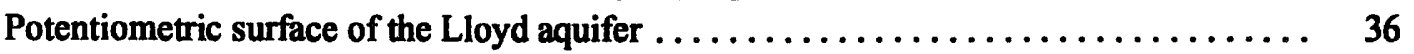

Distribution of hydraulic head along selected vertical sections $\ldots \ldots \ldots \ldots \ldots \ldots \ldots . \ldots \ldots$

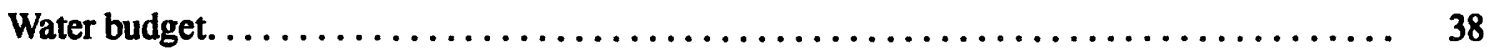

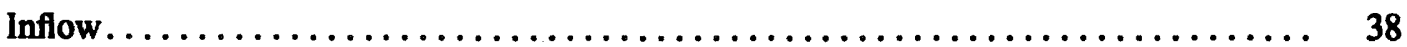

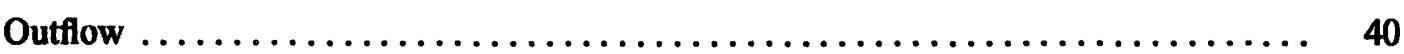

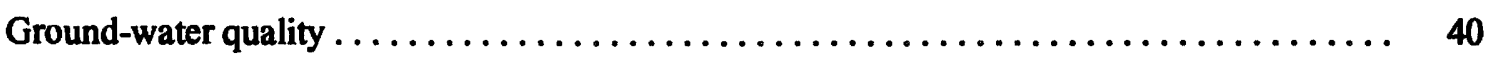

Extent of human-induced contamination. ....................... 41

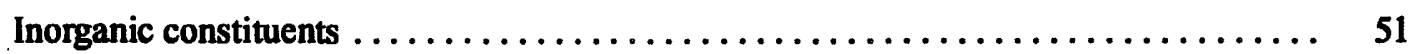

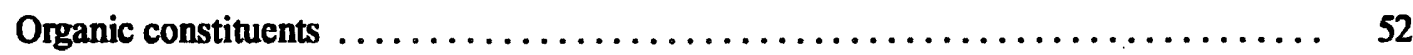

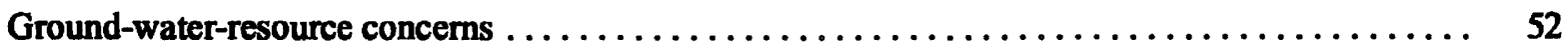

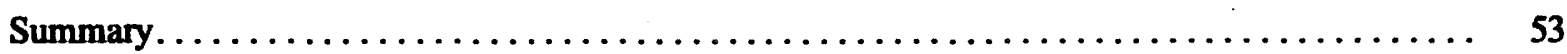

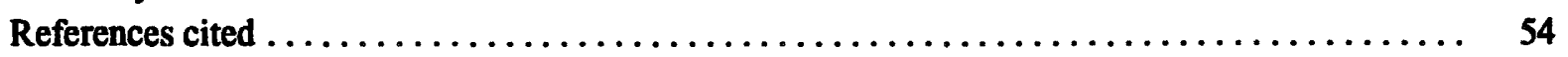




\section{FIGURES}

1. Map showing location of study area (Kings, Queens, and westem Nassau Counties) ...

2. Hydrologic section showing estimated flow patterns along section B-B' under predevelopment conditions $\ldots \ldots \ldots \ldots \ldots \ldots \ldots \ldots \ldots \ldots \ldots \ldots \ldots \ldots \ldots \ldots \ldots, \quad 9$

3. Map showing water-table configuration in $1903 \ldots \ldots \ldots \ldots \ldots \ldots \ldots \ldots \ldots \ldots$

4. Graphs showing annual average pumpage for industrial and public supply in Kings

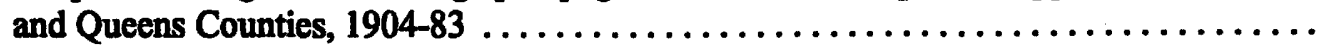

5. Graphs showing annual average public-supply pumpage from individual aquifers in Kings and Queens Counties, 1904-83.............................

6. Maps showing water-table configuration in:

A. 1936. B. 1943. C. 1951 . D. 1961 . E. 1974

7. Graphs showing average chloride concentration and total pumpage from eight driven wells at the Shetucket pumping station, $1897-1905 . \ldots \ldots \ldots \ldots \ldots \ldots \ldots \ldots$

8. Graphs showing chloride concentration in water from selected wells in Kings and Queens Counties: A. Wells screened in the upper glacial aquifer. B. Wells screened in the Jameco aquifer

9-11. Maps showing:

9. Chloride concentration in the upper glacial aquifer in :

A. 1947. B. 1961 . C. 1970 .

10. Upper surface altitude of deposits with low permeability at base of water-table aquifer in northern Kings and Queens Counties......................

11. Distribution of hydraulic head in southern Queens and southwestern Nassau County,

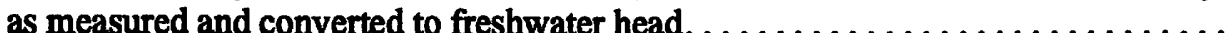

12-14. Maps showing (A) chloride, and (B) nitrate concentrations in 1983 in:

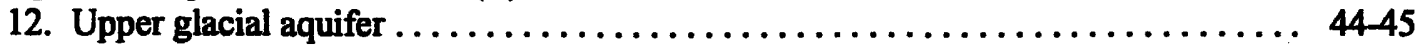

13. Jameco-Magothy aquifer $\ldots \ldots \ldots \ldots \ldots \ldots \ldots \ldots \ldots \ldots \ldots \ldots \ldots \ldots \ldots \ldots \ldots$ 46-47

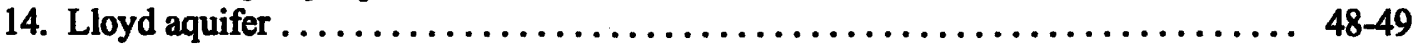

15. Hydrogeologic sections showing nitrate and chloride concentrations $\ldots \ldots \ldots \ldots \ldots \ldots$ 50-51

\section{TABLES}

1. Western Long Island stratigraphic column with geologic and hydrogeologic interpretation. .... 4

2. Predevelopment ground-water budget $\ldots \ldots \ldots \ldots \ldots \ldots \ldots \ldots \ldots \ldots \ldots \ldots \ldots \ldots \ldots$

3. Chemical composition of Long Island ground water and precipitation under predevelopment

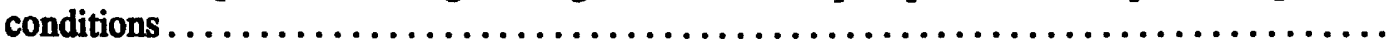

4. Number of observation wells in which water levels were measured from January through April 1983. 


\section{TABLES (continued)}

5. Equivalent freshwater heads at wells affected by saline water in the Jameco-Magothy aquifer.

6. Water budgets for predevelopment and recent (1983) conditions

7. Wells and test borings that occupy a multiple-well site

8. Observation wells whose records were used to produce maps of water-table and potentiometric-surface altitudes.

9. Hydrogeologic units penetrated by wells and test holes in Kings, Queens, Nassau, Bronx, New York, and Richmond Counties ...

10. Selected chemical analyses of water samples from observation wells in Kings, Queens, and eastern Nassau Counties. . . . . . . . . . . . . . . . . . . . . . . . . . . . .

11. Selected chemical analyses of water samples from public-supply wells in Kings, Queens,

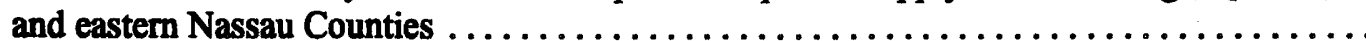

\section{PLATES}

(in pocket)

1. Map showing locations of wells used to determine altitude of tops of geologic units

2. Selected hydrogeologic sections

3. Maps showing upper surface altitude of :
A. Crystalline bedrock.
B. Lloyd Sand Member of the Raritan Formation
C. Clay member of the Raritan Formation
D. Magothy Formation and Matawan Group
E. Jameco Gravel
F. Gardiners Clay

4. Map showing the 1983 water-table configuration

5-6. Maps showing the 1983 potentiometric-surface altitude in:

5. Jameco-Magothy aquifer

6. Lloyd aquifer

7. Hydrologic sections showing distribution of hydraulic head in 1983

8. Map showing locations of wells sampled in 1983 
CONVERSION FACTORS AND VERTICAL DATUM

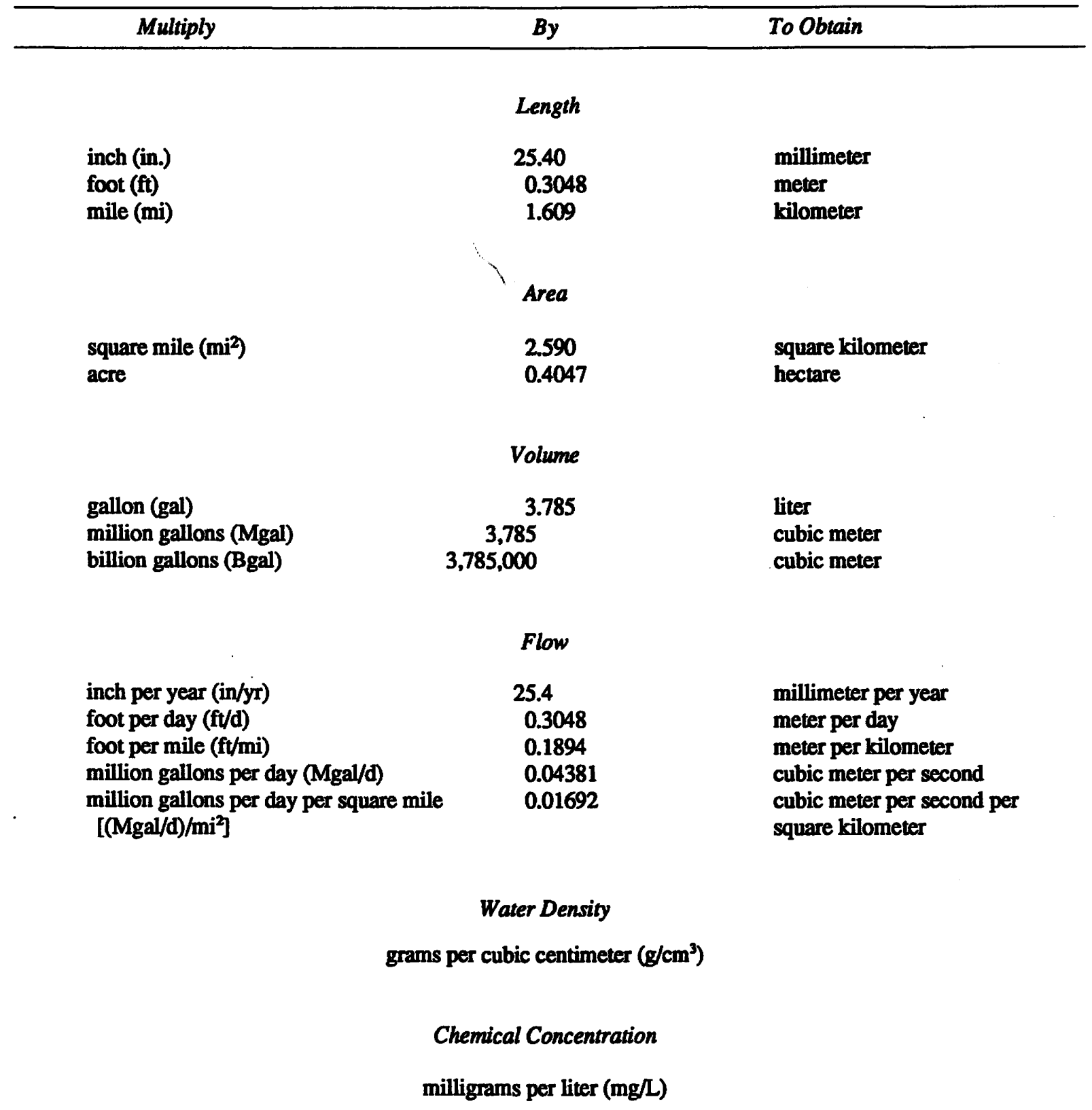

Sea level: In this report "sea level" refers to the National Geodetic Vertical Datum of 1929 (NGVD of 1929) -a geodetic datum derived from a general adjustment of the firstorder level nets of both the United States and Canada, formerly called Sea level datum of 1929. 


\title{
GROUND-WATER RESOURCES OF KINGS AND QUEENS COUNTIES, LONG ISLAND, NEW YORK
}

\author{
by Herbert T. Buxton and Peter K. Shernoff
}

\begin{abstract}
The aquifers beneath Kings and Queens Counties supplied an average of more than $120 \mathrm{Mgal} / \mathrm{d}$ (million gallons per day) for industrial and public water supply during 1904-47, but this pumping caused saltwater intrusion and a deterioration of water quality that led to the cessation of pumping for public supply in Kings County in 1947 and in western Queens County in 1974. Since the cessation of pumping in Kings and western Queens Counties, ground-water levels have recovered steadily, and the saltwater has partly dispersed and become diluted. In eastern Queens County, where pumpage for public supply averages $60 \mathrm{Mgal} / \mathrm{d}$, all three major aquifers contain a large cone of depression. The saltwater-freshwater interface in the Jameco-Magothy aquifer already extends inland in southeastern Queens County and is moving toward this cone of depression. The pumping centers' proximity to the north shore also warrants monitoring for saltwater intrusion in the Flushing Bay area.

Urbanization and development on western Long Island since before the turn of this century have caused significant changes in the ground-water budget (total inflow and outflow) and patterns of movement. Some of the major causes are: (1) intensive pumping for industrial and public supply; (2) paving of large land-surface areas; (3) installation of a vast network of combined (storm and sanitary) sewers; (4) leakage from a water-supply-line network that carries more than $750 \mathrm{Mgal} / \mathrm{d}$; and (5) burial of stream channels and extensive wetland areas near the shore.

Elevated nitrate and chloride concentrations throughout the upper glacial (water-table) aquifer indicate widespread contamination from land surface. Localized contamination in the underlying Jameco-Magothy aquifer is attributed to downward migration in areas of hydraulic connection between aquifers where the Gardiners Clay is absent. A channel eroded through the Raritan confining unit provides a pathway for migration of surface contaminants to the Lloyd aquifer sooner than anticipated. Although ground water in the Lloyd aquifer is still pristine, present pumping rates and potentiometric levels in the Lloyd indicate that this aquifer is much more sensitive to withdrawals than the other aquifers are and contains an extremely limited water supply.
\end{abstract}

\section{INTRODUCTION}

Kings and Queens Counties (the boroughs of Brooklyn and Queens in New York City) are at the western end of Long Island (fig. 1). This area has been extensively urbanized for more than 100 years. In 1980, the population of Kings County was 2.2 million, and the population of Queens was 1.89 million. The Long Island ground-water system, including the part beneath Kings and Queens Counties, is the sole source of water supply for the 2.6 million inhabitants of Nassau and Suffolk Counties to the east.

Ground water has been a source of public supply for western Long Island since the mid-19th century. Rapid increases in population since the turn of this century, and the attendant increases in pumping for public supply and industry, have resulted in severe water-level declines and intrusion of saline water from the surrounding bays. As a result, pumping for public supply in Kings County was stopped in 1947 and in western Queens County in 1974. (These areas now obtain water from mainland surface-water reservoirs.) As the early pumping centers in Kings and westem Queens County were abandoned, new ones were established farther east in areas more distant from the shore, where water-table altitudes are higher.

Since the cessation of pumping, water levels in Kings and western Queens Counties have 
recovered continually. Even in areas where the water table had been drawn down to as much as $35 \mathrm{ft}$ below sea level, it is now above sea level. In many of these areas, subways and deep basements that were constructed in the early 20 th century, when water levels were depressed, are now being flooded as the water table recovers and need to be dewatered continually. By 1983, eastem Queens County was withdrawing almost $60 \mathrm{Mgal} / \mathrm{d}$ for public supply, enough to cause concern that salt- water intrusion may resume.

In 1981-86, the U.S. Geological Survey (USGS) conducted an investigation of the western part of the Long Island ground-water system in cooperation with the New York State Department of Environmental Conservation and the New York City Department of Environmental Protection. The area included all of Kings (about $76 \mathrm{mi}^{2}$ ) and Queens (about $113 \mathrm{mi}^{2}$ ) Counties and about $50 \mathrm{mi}^{2}$ in westernmost Nassau County (fig. 1).

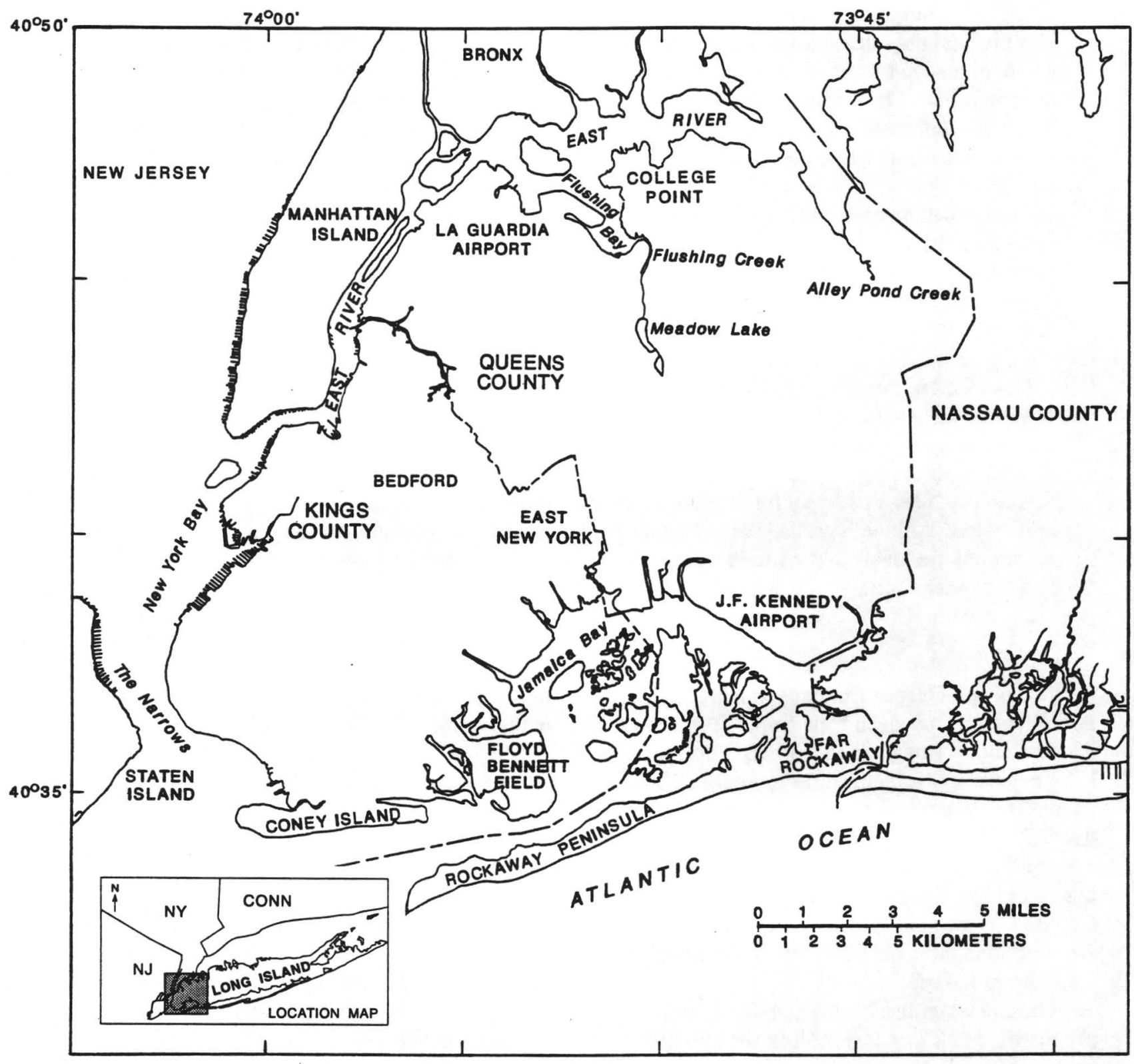

Figure 1. Location of Kings, Queens, and western Nassau County study area, Long Island, N.Y. 


\section{Purpose and Scope}

This report describes the structure and operation of the western part of the Long Island groundwater system. It describes the hydrologic effects associated with human development in this highly urbanized environment from 1900 to the early 1980's. The ground-water quantity and quality of recent (early 1980's) conditions is characterized and a discussion of ground-water resource concerns is offered. Specifically, it:

1. delineates the hydrogeologic framework of the western part of the Long Island groundwater system and defines its water-bearing characteristics,

2. describes ground-water flow patterns, the ground-water-system budget, and ground-water quality under predevelopment conditions,

3. summarizes the development of the groundwater system and the effects of urbanization by presenting historical pumpage data and other urbanizing factors, and presenting the subsequent response of the ground-water system, and

4. presents the recent patterns and distribution of ground-water flow, and concentrations of selected chemical constituents that indicate the extent of human-derived contamination and saltwater intrusion throughout the ground-water system.

\section{Acknowledgments}

The authors thank the New York State Department of Environmental Conservation and the New York City Department of Environmental Protection for support and cooperation. Special thanks are given to Jerry Iwan and the staff of the Bureau of Water Supply Laboratory of the New York City Department of Environmental Protection for cooperation in handling and chemical analysis of water samples.

\section{HYDROGEOLOGIC FRAMEWORK}

The ground-water system that underlies westem Long Island consists of a series of unconsolidated deposits of clay, sand, and gravel of Late Cretaceous and Pleistocene age that are underlain by Precambrian(?) bedrock. The stratigraphic relations of the geologic units are summarized in table 1 ; the geometry of these units is depicted in vertical sections on plate 2 and in hydrogeologic maps on plate 3. The water-transmitting properties of the corresponding hydrogeologic units are described also.

\section{Hydrostratigraphy}

Bedrock was eroded to a peneplain before deposition the overlying Cretaceous sediments; its surface shows signs of later erosion by Pleistocene glaciation in the northwest (pl. 3A; see also sections A-A' and B-B' on pl. 2). Bedrock crops out in northwestern Queens County near the East River and slopes southeastward at about 80

$\mathrm{ft} / \mathrm{mi}$. Consequently, the overlying unconsolidated formations form a wedge-shaped mass that attains a maximum thickness of more than $1,100 \mathrm{ft}$ in the southeastern comer of Queens County. The maximum thickness in Kings County is about $900 \mathrm{ft}$, in southeastern Kings.

Overlying bedrock is the Raritan Formation of Late Cretaceous age, which consists of the Lloyd Sand Member and an upper, unnamed clay member. Overlying the Raritan Formation are the Magothy Formation and Matawan Group, undifferentiated, also of Late Cretaceous age; the Jameco Gravel and the Gardiners Clay, both of Pleistocene age; upper Pleistocene deposits of Wisconsin age; and a generally thin soil mantle of Holocene age (table 1 and pl. 2). Holocene beach deposits form most of the Rockaway Peninsula and Coney Island in the south, and Holocene salt-marsh deposits underlie and fringe the south-shore bay areas. Artificial filling has buried some marsh deposits in low and swampy shore areas. Because Holocene deposits occur only in relatively small areas of Kings and Queens and are not significant water bearers, they are not included in the geologic descriptions that follow. 
Table 1. Western Long Island stratigraphic column with geologic and hydrogeologic interpretation

\begin{tabular}{|c|c|c|c|c|c|c|}
\hline System & Series & \multicolumn{2}{|c|}{ Geologic Unit } & $\begin{array}{c}\text { Hydrogeologic } \\
\text { unit }\end{array}$ & $\begin{array}{c}\text { Range of } \\
\text { thickness, } \\
\text { in feet }\end{array}$ & $\begin{array}{l}\text { Range of } \\
\text { altitude of upper } \\
\text { surface, in feet } \\
\text { above sea level }\end{array}$ \\
\hline \multirow{4}{*}{ 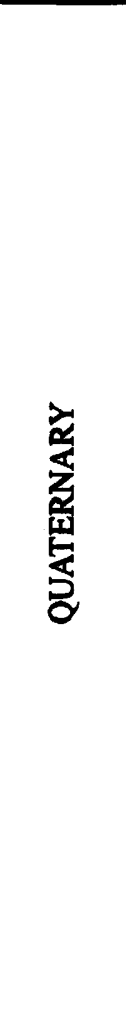 } & Holocene & \multicolumn{2}{|c|}{$\begin{array}{l}\text { Shore, beach salt-marsh } \\
\text { deposits, and alluvium }\end{array}$} & & & \\
\hline & \multirow{3}{*}{ 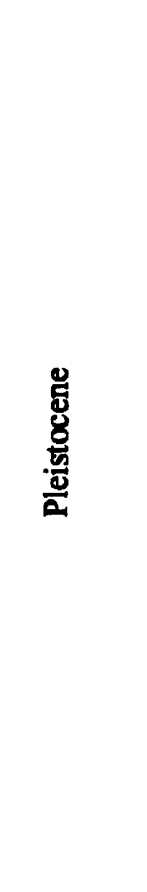 } & 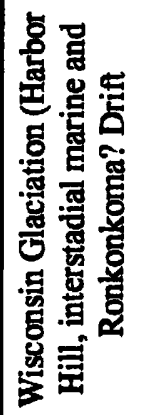 & $\begin{array}{c}\text { Till (ground and } \\
\text { terminal moraine) } \\
\text { Outwash } \\
\text { "20-foot" clay } \\
\text { (marine) }\end{array}$ & $\begin{array}{l}\text { Upper Glacial } \\
\text { aquifer }\end{array}$ & 0 to 300 & Land surface \\
\hline & & 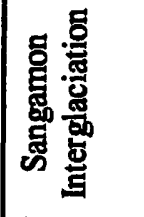 & $\begin{array}{l}\text { Gardiners Clay } \\
\text { (marine) }\end{array}$ & Gardiners Clay & 0 to 150 & -40 to -200 \\
\hline & & 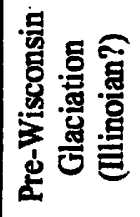 & Jameco Gravel & Jameco aquifer ${ }^{1}$ & 0 to 200 & -90 to -240 \\
\hline \multirow{3}{*}{ 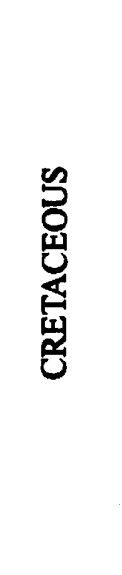 } & \multirow{3}{*}{ 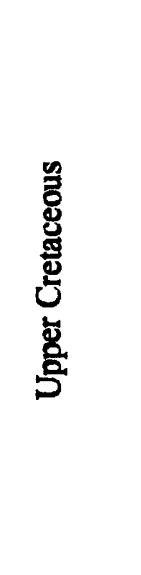 } & \multicolumn{2}{|c|}{$\begin{array}{l}\text { Magothy } \\
\text { Matawan Group } \\
\text { undifferentiated }\end{array}$} & $\begin{array}{l}\text { Magothy } \\
\text { aquifer }{ }^{1}\end{array}$ & 0 to 500 & 40 to -400 \\
\hline & & \multirow{2}{*}{ 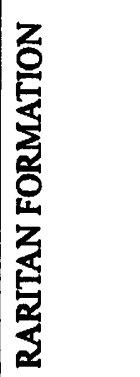 } & Clay member & $\begin{array}{c}\text { Raritan } \\
\text { confining unit }\end{array}$ & 0 to 200 & 30 to -650 \\
\hline & & & $\begin{array}{l}\text { Lloyd sand } \\
\text { member }\end{array}$ & Lloyd aquifer & 0 to 300 & -90 to -825 \\
\hline \multicolumn{2}{|c|}{ Precambrian } & \multicolumn{2}{|c|}{ Crystalline bedrock } & Bedrock & - & 15 to -1100 \\
\hline
\end{tabular}

${ }^{1}$ The Magothy and Jameco aquifers are often considered as one hydrologic unit with differing hydraulic properties. (See discussion in text.) 
Erosion of the Cretaceous strata from Late Cretaceous through Pleistocene time has created a complex buried topography, as is seen in sections on plate 2. The data from which the hydrogeologic correlations were formulated consisted mainly of drillers' geologic logs, geophysical data, descriptive logs prepared by the USGS during inspection of cores of well-bore samples, and selected bridge and tunnel-boring data. These data are interpreted in relation to the area's erosional and depositional history. The altitude of each hydrogeologic unit's upper surface at each well is listed in table 9 (at end of report); locations of wells are shown on plate 1 . The numbers of all wells at multiple-well sites are given in table 7 (at end of report) to facilitate location of wells.

\section{Upper Cretaceous Deposits}

Lloyd Sand Member of the Raritan Formation.-The Lloyd Sand Member, the oldest Cretaceous deposit in the area, lies unconformably on bedrock. Its surface and extent were shaped by post-Cretaceous erosion. It is absent in northwestern Kings and Queens Counties (pl. 3B) and in a tributary buried-valley-system that trends southward from Flushing Bay to central Queens County (section E-E', pl. 2).

The Lloyd Sand Member consists mainly of deltaic deposits of fine to coarse quartzose sand interbedded with sand and small- to large-pebble quartzose gravel. Interbeds of silt and clay and silty and clayey sand are common throughout the unit (Soren, 1978). The member is overlain by the clay member of the Raritan Formation. The northern extent of the Lloyd Sand Member and the clay member are largely coincident where eroded in the buried-valley system in northern Queens (pl. 2), but the clay member extends well north of the underlying Lloyd Sand Member in western Queens and Kings Counties.

The Lloyd Sand Member ranges in thickness from zero at its northern edge to about $200 \mathrm{ft}$ in southeastern Kings County and $300 \mathrm{ft}$ in southeastern Queens County. The unit's surface is as high as $90 \mathrm{ft}$ below sea level in northern Queens and more than $800 \mathrm{ft}$ below sea level in southeastem Queens.

Clay Member of the Raritan Formation.This unit is absent along the northwest shore of Kings and Queens Counties (pl. 3C) and is croded in central Queens in the same buried-valley system as the Lloyd Sand Member, but the clay member has been more extensively eroded, especially to the south. The clay member consists mainly of deltaic clay and silty clay beds and some interbedded sand (Soren, 1978). It increases in thickness from a pinchout at its northern limit to about $250 \mathrm{ft}$ in southeastern Kings County and about $200 \mathrm{ft}$ in southeastern Queens County. Its upper surface is less than $50 \mathrm{ft}$ below sea level in Kings County and a few feet above sea level in parts of northern Queens. It is more than $400 \mathrm{ft}$ below sea level in southern Kings and $600 \mathrm{ft}$ below sea level in southeastern Queens.

The clay member overlies the Lloyd Sand Member with apparent conformity and, where the Lloyd Sand Member is absent, it lies unconformably on bedrock. It was disconformably overlain by Upper Cretaceous deposits, but during a complex geologic history after the Late Cretaceous Epoch, it became overlain from south to north by the Magothy Formation and Matawan Group, undifferentiated, the Jameco Gravel, the Gardiners Clay, and upper Pleistocene deposits, respectively (pl. 2).

Magothy Formation and Matawan Group.-The Magothy Formation and Matawan Group, undifferentiated, contains the remaining Cretaceous deposits in this area. This uppermost Cretaceous unit was severely eroded from the Late Cretaceous to the time of deposition of the Jameco Gravel (pl. 3D). The erosion is most severe in what was probably a complex channel network from an ancestral diversion of the Hudson River (Soren, 1978, p. 12-15). The Cretaceous unit in Kings and Queens Counties has a buried erosional surface with two prominent north-south trending channels, one through central Queens and one generally parallel to the Kings-Queens County line. These channels are eroded through the unit to near the south shore, where they apparently join and continue south as a single channel. Where the unit has been completely removed, dissection is evident in the underlying clay member and Lloyd Sand Member of the Raritan Formation (pl. 3B and 3C) and even in the bedrock in a small area of north-central Queens (pl. 3A).

The deposits of the Magothy Formation and Matawan Group, like the earlier Cretaceous deposits, are of continental origin and are mostly deltaic quartzose very fine to coarse sand and 
silty sand with lesser amounts of interbedded clay and silt. The unit commonly has a coarse quartzose sand and in many places a basal gravel zone 25 to $50 \mathrm{ft}$ thick.

The unit ranges in thickness from zero at its northern limits to more than $200 \mathrm{ft}$ in southern Kings and $500 \mathrm{ft}$ in southeastem Queens. It is thinner in the buried valleys. The altitude of the Magothy-Matawan surface ranges from a few feet above sea level in northeast Queens to more than $400 \mathrm{ft}$ below sea level in the buried valley to the south.

\section{Pleistocene Deposits}

Jameco Gravel.-The Jameco Gravel is the oldest Pleistocene deposit in the area (pl. 3E). It is considered to be a channel filling associated with an ancestral pre-Sangamon (Illinoian?) diversion of the Hudson River (Soren, 1978, p. 8). This episode of fluvial erosion probably was largely responsible for the irregular configuration of the Late Cretaceous land surface. The Jameco Gravel is present in most of Kings County and southern Queens County. It is thickest in the deep channels eroded into the underlying Magothy-Matawan unit and is thinnest over the higher areas. For example, a small area in southeastern Queens at Far Rockaway in which the Jameco Gravel has not been found coincides with a high point on the surface of the underlying formation (pl. 3D and section D-D' on pl. 2). Thickness of the Jameco Gravel ranges from a feather edge at its northern limit to more than $200 \mathrm{ft}$ in the main buried valley in the center of Jamaica Bay.

Jameco deposits consist mainly of a heterogeneous suite of igneous, metamorphic, and sedimentary rocks and are typically dark brown. The deposits grade from coarse sand and gravel with many cobbles and some boulders in the northern part of Kings County to finer grains southward. The presence of diabase fragments indicates transport by meltwater from a glacial terminus northwest of New York City. Soren (1978, p. 12-13) suggests that the Hudson River was diverted from its channel on the west of Manhattan Island to Queens County via the Harlem River channel and that distributary streams carried diabase fragments from there into Kings and Queens Counties.

The upper surface altitude of the Jameco Gravel is generally highest along the unit's northern edge- as little as $90 \mathrm{ft}$ below sea level in westem Kings County and $80 \mathrm{ft}$ below sea level in eastern Queens County. It is generally lower to the south and over the deep erosional channels in the Late Cretaceous surface, where it is more than $\mathbf{2 0 0}$ $\mathrm{ft}$ below sea level. The upper surface of the Jameco Gravel was probably modified by subsequent stream erosion and glaciation.

Gardiners Clay.-The Gardiners Clay underlies most of Kings County and southern Queens County (pl. 3F). It unconformably overlies the Jameco Gravel and generally overlaps it along most of its extent. It consists mainly of greenishgray clay and silt and some interbedded sand and was probably deposited in lagoonal and marine environments during an interglacial (Sangamon) interval (Soren, 1978, p. 10). The typical blue or green color of these beds is due to glauconite, chlorite, and weathered biotite. The Gardiners Clay was described as "blue clay" in many early 20 thcentury drillers' logs. Fossil shells, foraminifera, and disseminated lignite are widespread in the formation. The Gardiners Clay ranges in thickness from a feather edge at its northern limit to more than $100 \mathrm{ft}$ in areas of previous erosion. The surface of the Gardiners Clay is predominantly flat but is affected locally by glacial erosion along its northern extent and by compaction in areas of greatest thickness. The upper surface ranges from less than $50 \mathrm{ft}$ below sea level in the north to more than $150 \mathrm{ft}$ below sea level in southern Kings County. It has not been found higher than $\mathbf{4 0} \mathrm{ft}$ below sea level anywhere on Long Island, probably because its deposition was controlled by a relatively constant sea level. The Gardiners Clay is probably absent in two localized areas in the southern part of the area where underlying deposits (Magothy Formation and Matawan Group and Jameco Gravel) are at a higher altitude than the projected surface of the Gardiners Clay (pl. 3F). One area is near Floyd Bennet field in southem Kings (section B-B', pl. 2); the other is in Far Rockaway.

Upper Pleistocene Deposits.-These deposits are of Wisconsin age and of glacial origin. They unconformably overlie all underlying units and are found at land surface in nearly all of Kings and Queens Counties. The surficial geology of this area was mapped by Fuller (1914). The glacial deposits include: (1) terminal moraine deposits emplaced by an ice front of Harbor Hill age 
(location shown in fig. 3, p. 10); (2) groundmoraine deposits north of the terminal moraine; and (3) glacial outwash deposits south of the terminal moraine. The upper Pleistocene deposits range in thickness from zero in small areas of northwestern Queens, where bedrock crops out, to as much as $300 \mathrm{ft}$ in the terminal moraine and near the buried valleys.

The terminal moraine is an unsorted and unstratified mixture of clay, sand, gravel, and boulders that were accumulated at the front of a continental glacier. The ground moraine is similar to the terminal-moraine deposits but was deposited at the base of the ice sheet during periods of melting. Meltwater from the ice front flowed southward and carried sand and gravel in broad, coalescing sheets to form an outwash plain that extends from the terminal moraine south to the coast.

Pre-Harbor Hill deposits are present at depth in the sequence of upper Pleistocene deposits (table 1). The " 20 -foot" clay in eastern Queens and Nassau Counties is a marine clay deposited during the Ronkonkoma-Harbor Hill interstade (Soren, 1978, p. 11). This unit locally separates the Harbor Hill Drift from the underlying Ronkonkoma Drift and earlier deposits.

\section{Water-Transmitting Properties}

The six major geologic units described in the preceding section generally correspond to hydrologic units with specific water-bearing characteristics. These hydrologic units and their corresponding geologic names (table 1) are, in ascending order, the Lloyd aquifer (Lloyd Sand Member of the Raritan Formation), the Raritan confining unit (the clay member of the Raritan Formation), the Magothy aquifer (Magothy Formation and Matawan Group, undifferentiated), the Jameco aquifer (Jameco Gravel), the Gardiners Clay (Gardiners Clay), and the upper glacial aquifer (upper Pleistocene deposits).

The aquifers are arcally extensive unconsolidated formations that yield significant quantities of water to wells. The most permeable units are the beds of predominantly sand or sand and gravel. The two clayey formations (the Gardiners Clay and Raritan confining unit) are significant confining units and have been estimated to have a vertical hydraulic conductivity of $0.001 \mathrm{ft} / \mathrm{d}$ (Franke and Cohen, 1972), several orders of magnitude lower than that of the aquifers. Where present, they separate the groundwater reservoir into three major aquifer units- the Lloyd, the Jameco-Magothy, and the upper glacial aquifers (pl. 2). The Gardiners Clay restricts vertical flow between the upper glacial and JamecoMagothy aquifers, and the Raritan confining unit restricts vertical flow between the Jameco-Magothy and Lloyd aquifers. Where these confining units are absent, ground-water flow between aquifer units is uninhibited. The extent of the confining units is critical in defining the distribution of hydraulic head and ground-water flow patterns.

The bedrock underlying the unconsolidated deposits has a low hydraulic conductivity and does not yield more than a few gallons per minute to wells. The quantity of water that can flow across this boundary is insignificant compared with the quantities that flow in the overlying unconsolidated units. Therefore, the bedrock surface is considered to be the bottom boundary of the ground-water fiow system.

\section{Lloyd Aquifer}

The Lloyd aquifer has moderate horizontal hydraulic conductivity, which McClymonds and Franke (1972) estimated to range from 50 to 70 $\mathrm{ft} / \mathrm{d}$, although individual sandy and gravelly beds within the aquifer could have much higher values. High-capacity wells that tap the Lloyd aquifer generally have been pumped at rates less than 1,000 $\mathrm{gal} / \mathrm{min}$, but pumpage as high as $1,600 \mathrm{gal} / \mathrm{min}$ from a single well has been reported (Soren, 1971, p. 11). Specific capacities of wells screened in the Lloyd aquifer, in gallons per minute pumped per foot of drawdown in the well, ( $\mathrm{gal} / \mathrm{min}) / \mathrm{ft}$, range from 4 to about $40(\mathrm{gal} / \mathrm{min}) / \mathrm{ft}$ (Soren, 1971, p. 11). The Lloyd aquifer is confined between the bedrock and the Raritan confining unit but is in good hydraulic connection with the overlying aquifers where the confining unit has been eroded (pl. 3B).

\section{Jameco-Magothy Aquifer}

Although the Magothy and Jameco deposits differ in origin, lithologic character, and watertransmitting properties, they are considered as one aquifer unit in this report and are referred to as the Jameco-Magothy aquifer. The Jameco Gravel was deposited in deep channels incised in the Magothy aquifer and provides good hydraulic connection 
between these units as shown in plate 2 (sections A-A', B-B', D-D', and E-E'). In addition, these deposits are hydraulically separated from the underlying Lloyd aquifer by the Raritan confining unit and from the overlying upper glacial aquifer by the Gardiners Clay. The lateral hydraulic continuity between the Jameco and Magothy aquifers enables both to act as a single aquifer in which the Jameco is merely a zone of higher hydraulic conductivity.

The hydraulic conductivity of the Magothy aquifer has been estimated to range from 60 to $90 \mathrm{ft} / \mathrm{d}$ (McClymonds and Franke, 1972), but, as in the Lloyd aquifer, individual sandy and gravelly beds could have values several times higher. No pumping of the Magothy aquifer in Kings County is known, but wells that tap the Magothy in Queens County have yielded as much as $1,500 \mathrm{gal} / \mathrm{min}$. The specific capacities of wells tested have ranged from 15 to $30(\mathrm{gal} / \mathrm{min}) / \mathrm{ft}$ in fine sand to 50 (gal/min)/ft in coarser material (Soren, 1971, p. 10).

Soren (1971, p. 9) estimated the horizontal hydraulic conductivity of the Jameco aquifer to be at least $270 \mathrm{ft} / \mathrm{d}$. Wells tapping the Jameco have yielded $1,600 \mathrm{gal} / \mathrm{min}$, and specific capacities of wells in the Jameco as high as $180(\mathrm{gal} / \mathrm{min}) / \mathrm{ft}$ have been reported (Soren, 1971, p. 9). Although the Jameco aquifer is considerably thinner than the Magothy, their transmissivities are comparable.

The Jameco-Magothy aquifer system is confined in southern Queens and in Kings County wherever it lies between the Gardiners Clay and the Raritan confining unit (pls. 2 and 3F). In north- em Queens, however, the Magothy attains altitudes above sea level and is in good hydraulic connection with the water-table aquifer. Lenses and beds of clay and silty clay whose overlapping arrangement produces an anisotropy of perhaps as high as 100:1 tend to cause a confining effect with depth.

\section{Upper Glacial Aquifer}

The upper glacial aquifer consists of saturated glacial drift. Sand and gravel beds deposited as outwash south of the terminal moraine are highly permeable and are capable of yielding large quantities of water. Horizontal hydraulic conductivity of glacial outwash has been estimated to be $270 \mathrm{ft} / \mathrm{d}$ (Franke and Cohen, 1972); horizontal hydraulic conductivity of moraine deposits on the north shore, which include considerable clay and silt and are poorly sorted, is probably less than half that value. Public-supply and other high-capacity wells that tap outwash deposits have commonly yielded as much as $1,500 \mathrm{gal} / \mathrm{min}$ and have specific capacities ranging from 50 to $60(\mathrm{gal} / \mathrm{min}) / \mathrm{ft}$ (Soren, 1971, p. 8). Scattered coarse sand and gravel lenses within the morainal deposits have the potential for yielding significant amounts of water, but their locations can not be predicted.

Water in the upper glacial aquifer is under water-table (unconfined) conditions but probably is confined locally between beds of clay and silt within the morainal deposits. Such clayey and silty beds, where near the water table, impede groundwater recharge and thus locally cause unusually high water levels and temporary ponding that is often confused with perched conditions.

\section{PREDEVELOPMENT HYDROLOGIC CONDITIONS}

The only natural source of freshwater recharge to the Long Island ground-water system is precipitation, which replenishes the large volume of fresh water stored in the unconsolidated deposits. The ground-water system is bounded on top by the water table, on the bottom by bedrock, and on the sides by saline ground water or surface-water bodies (fig. 2). The ground water is in continuous motion from the water table to its point of discharge. The path of flow is three dimensional and is affected by the geometry and hydraulic characteristics of the aquifers and confining units, and by the proximity and nature of discharge boundaries.

Much of the water that enters the ground-water system remains in the upper glacial aquifer, where it moves laterally and discharges to streams or the surrounding saltwater bodies (fig. 2). groundwater seepage to streams results in shallow ground-water circulation patterns or flow subsystems (Franke and Cohen, 1972). (These shallow flow systems are not shown in fig. 2.)

The rest of the water that enters the system flows downward to the Jameco-Magothy aquifer (fig. 2), and some flows still deeper to the Lloyd 
aquifer. This downward movement of water is greater in areas of continuity between aquifer units than in areas of confining units, where it moves much more slowly and is refracted to near vertical through the confining units. All ground water eventually moves seaward. Near the shore, downward gradients reverse, and water moves upward into shallower aquifers. The seaward extent of fresh ground water in the confined aquifers is the interface between fresh and saline ground water. Water generally flows upward along this interface. Saline water has a greater density than freshwater; at large scales, the two fluids behave largely as though immiscible. Although a zone of diffusion forms at the interface, mixing is minimal under nonpumping conditions, and flow across the interface is virtually nil. Water from the confined aquifers flows upward through the Raritan confining unit or Gardiners Clay and mixes with overlying saline ground water and thus is lost from the freshwater system.

\section{Water-Table Configuration}

The configuration of the water table indicates the horizontal pattern of ground-water movement and the amount of freshwater stored in the groundwater reservoir. The first map of the water-table configuration on Long Island, made in 1903 (fig. 3 ), provides the best available estimate of the predevelopment water-table configuration, although urbanization and development of the ground-water system even then had begun to affect water levels.

The water table in 1903 had a steep gradient westward into Queens County (fig. 3), which indicates that a significant quantity of ground water entered Queens County from the east and helped maintain water levels in both Kings and Queens Counties. The water table reached an altitude of over $50 \mathrm{ft}$ at the Queens-Nassau County line (fig. 3) and, in central Nassau County, attained a maximum altitude of over $90 \mathrm{ft}$ (Veatch and others, 1906).

Long Island's major ground-water divide trends east-west through northern Queens County, then gradually southward through Kings County (fig. 3). The asymmetry of the water table from north to south, with steep northward gradients and flatter southward gradients (fig. 3), has three causes: (1) the thickening of the aquifers southward, (2) higher hydraulic conductivity in the outwash plain south of the divide than in moraine deposits north of it, and (3) more ground-water seepage to south-shore streams than to north-shore streams. These characteristics also are observed in the present water-table configuration.

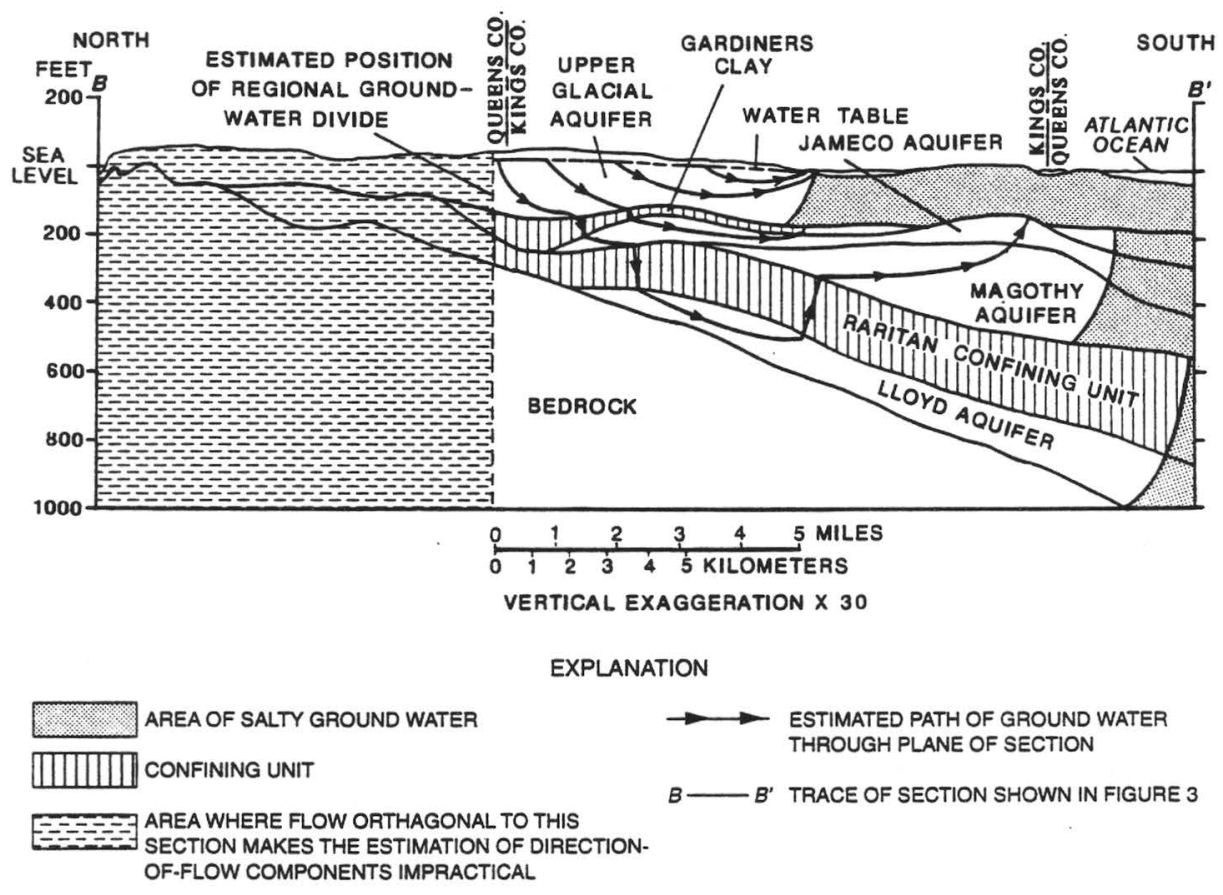

Figure 2. Estimated flow patterns along Section B-B' under predevelopment conditions. (Location is shown in fig. 3.) 


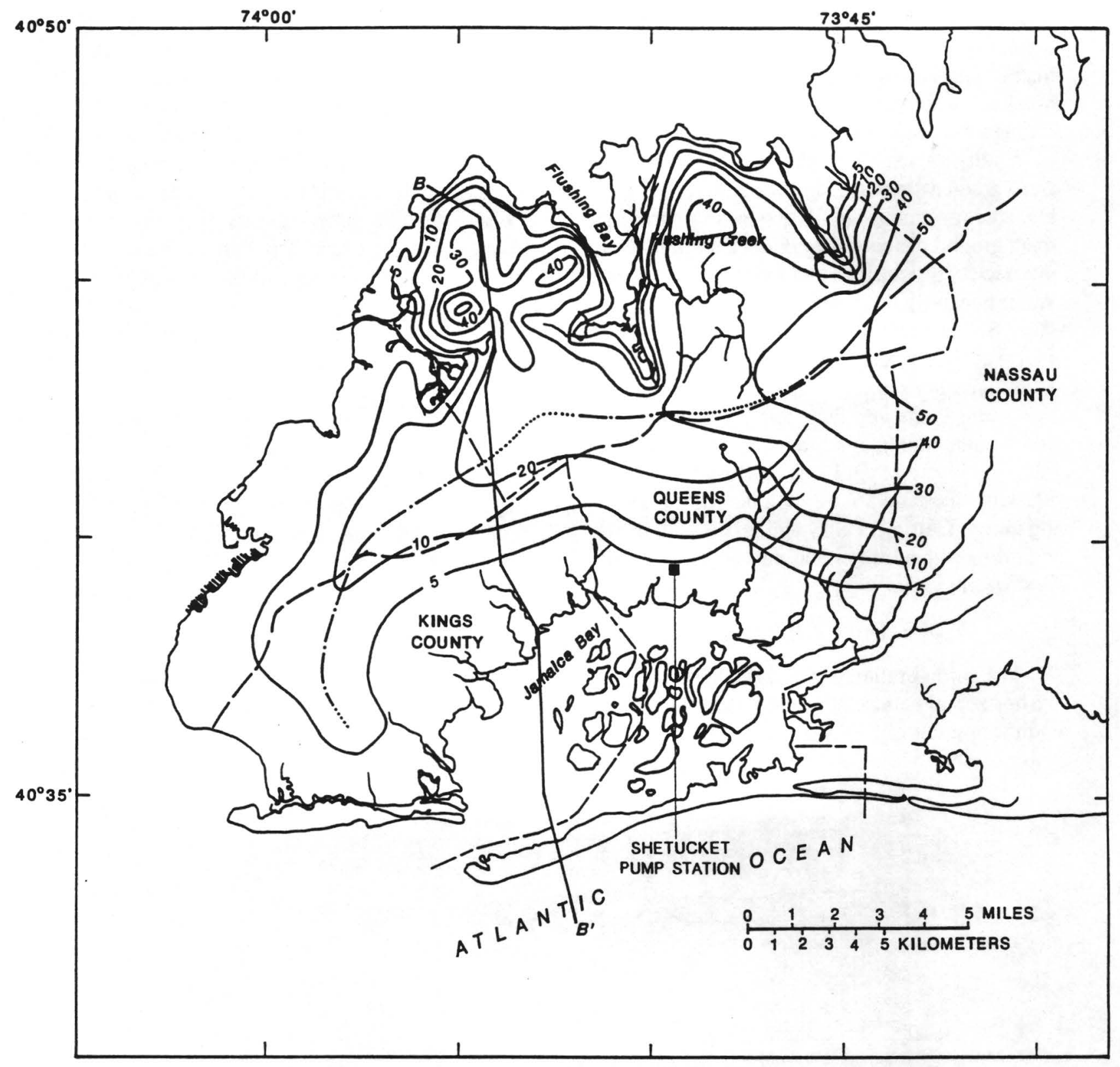

EXPLANATION

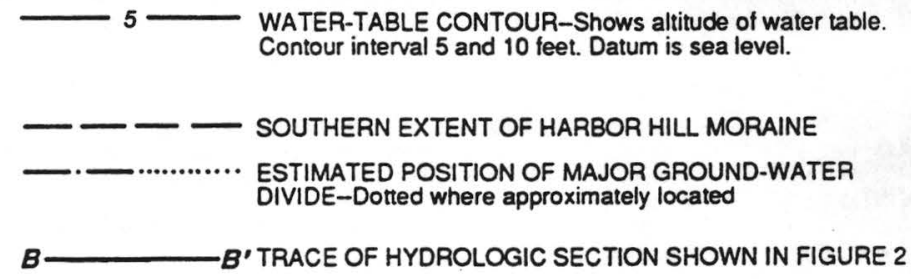

Figure 3. Water table in 1903. Section $B-B^{\prime}$ is depicted in figure 2. (Modified from Veatch and others, 1906.) 
The ground-water levels of 1903 indicate steep ground-water gradients toward several stream channels in Kings and Queens Counties. Flow in these channels, which are relict from the glacial period, was sustained primarily by ground-water seepage. The presence of many stream channels and swampy areas in southern Kings and Queens Counties suggests that a significant quantity of ground water discharged to surface-water bodies in this area.

Areas of anomalously high water levels are evident on the north shore of Queens County (fig. 3). These are caused by the high altitude of the bedrock surface (pl. 2A) in this area and by zones of low hydraulic conductivity in the moraine deposits, which restrict ground-water discharge to Long Island Sound. Similarly high water levels are associated with moraine deposits farther east on Long Island.

\section{Water Budget}

Before development, the Long Island ground-water system was in a state of dynamic equilibrium. Although the system fluctuates in response to natural variations in precipitation, an average predevelopment hydrologic condition can be estimated. Under predevelopment conditions, water entered the part of the Long Island ground-water system that underlies Kings and Queens Counties as recharge from precipitation and, to a lesser degree, as ground-water inflow from Nassau County. Water discharged by seepage to streams and to the surrounding saline ground-water and surface-water bodies. The quantities of these inflows and outflows under predevelopment (equilibrium) conditions are presented in table 2 . The estimates given in table 2 were obtained through evaluation of hydrologic records in conjunction with results of flow-model analysis of the entire Long Island ground-water system. This model is being developed in a concurrent study by the U.S. Geological Survey $(H$. T. Buxton and D. A. Smolensky, U.S. Geological Survey, written commun., 1988), and much of the hydrogeologic information presented here was used in model construction.

Hydrologic data from central and eastern Long Island indicate that, under predevelopment conditions, about 50 percent of the annual precipitation infiltrated to the water table and recharged the ground-water system (Franke and McClymonds, 1972); the remainder was lost through evapotranspiration and direct (overland) runoff. Precipitation on Long Island ranges from 42 to 47 inches per year and averages 44 inches (Miller and Frederick, 1972). About 21 inches is estimated to have been lost through evapotranspiration, and only 1 inch lost as direct runoff.

About $396 \mathrm{Mgal} / \mathrm{d}$ of precipitation fell on the 189- $\mathrm{mi}^{2}$ area of Kings and Queens Counties during predevelopment conditions. Of this total, $209 \mathrm{Mgal} / \mathrm{d}$ is estimated to have become recharge (table 2); this equals an average recharge rate of $1.1(\mathrm{Mgal} / \mathrm{d}) / \mathrm{mi}^{2}$ (82 $\mathrm{Mgal} / \mathrm{d}$ over the $76 \mathrm{mi}^{2}$ of Kings County and $127 \mathrm{Mgal} / \mathrm{d}$ over the $113 \mathrm{mi}^{2}$ of Queens County). The remaining inflow to western Long Island (from Nassau County) is estimated to have been $6 \mathrm{Mgal} / \mathrm{d}$. Therefore, the total inflow to the ground-water reservoir beneath Kings and Queens Counties under predevelopment conditions was $215 \mathrm{Mgal} / \mathrm{d}$.

An equal rate of ground-water discharge to streams (base flow) and to saline ground-water bodies (subsea discharge) balances this inflow. Before 1900, about 15 streams flowed in Kings and Queens Counties, the base flow of which is estimated to have been between 90 and 95 percent of their total flow. An examination of streamflow measurements made around the turn of the century (Veatch, 1906; Burr, Hering, and Freeman, 1904; and Spear, 1912), indicated that about $62 \mathrm{Mgal} / \mathrm{d}$ discharged from the ground-water system to streams as base flow-almost 30 percent of the water budget of the area. Thus, the remaining $153 \mathrm{Mgal} / \mathrm{d}$ discharged as subsea discharge, as explained in the previous section and shown in figure 2.

Table 2. Predevelopment ground-water budget

[Values are in million gallons per day.]

$\begin{aligned} & \text { Inflow } \\ & \text { Recharge from precipitation } \ldots \ldots \ldots \ldots \ldots \ldots\end{aligned}$
Ground-water inflow from Nassau County $\ldots$
Total $\ldots \ldots \ldots \ldots \ldots \ldots \ldots \ldots \ldots \ldots \ldots \ldots \ldots \ldots \ldots \ldots$




\section{Ground-Water Quality}

Little if any information on ground-water quality in western Long Island under predevelopment conditions is available. The chemical composition of water samples taken from wells in eastern Long Island during 1932-65 is summarized in table 3. The eastern part of the island generally is similar to Kings and Queens geologically and climatically but was not urbanized until much later. These data, therefore, are the most reliable indication of predevelopment ground-water quality in the western part of Long Island.

The Jameco Gravel, which underlies only western Long Island, could affect the ground-water quality there, however, because it contains abundant ferromagnesium minerals, but no data are available to indicate its effect on water quality under predevelopment conditions. Elsewhere the aquifers consist primarily of quartz and, except for the dissolution of silica, are relatively unreactive. Much of the dissolved-solids content of Long Island's ground water under predevelopment conditions was derived from constituents dissolved in precipitation (table 3). Pearson and Fisher (1971) suggest a method of estimating chemical concentrations in water that recharges the ground-water system-the concentration in precipitation is multiplied by a specific factor to account for the effects of evapotranspiration. Given that about half of the precipitation on Long Island is lost through evapotranspiration (Franke and McClymonds, 1972, p. 19), a factor of 2 would be used. This method can be used throughout the following discussion to indicate what proportion of a conservative constituent was introduced in recharge water.

As water passes through the soil zone and moves through the aquifer, it undergoes reactions that modify its chemical character. The following paragraphs briefly describe the major inorganic constituents of Long Island's ground water.

Nitrate-Nitrate is the only major constituent found in lower concentrations in ground water than in precipitation (table 3). Nitrogen in the form of nitrate is an essential nutrient for most plants. When water from precipitation enters the soil zone, it is absorbed by roots and converted to organic nitrogen (nucleic acids and proteins). As a result, ground water contains less nitrogen than does precipitation (table 3). Kimmel (1972, p. D200) surveyed the available data on nitrate in ground water on eastern Long Island and concluded that the nitrate concentration of water in the upper glacial aquifer under predevelopment conditions was $0.2 \mathrm{mg} / \mathrm{L}$. The nitrate analyses shown in table 3 suggest that the predevelopment levels of nitrate could have been even lower.

Silica.-Silica $\left(\mathrm{SiO}_{2}\right)$ is the most abundant dissolved constituent of ground water under predevelopment conditions. Little if any silica enters the ground with recharge from precipitation (Hem, 1970, p. 48-50). Silica is taken into solution during the chemical decomposition of silicate minerals, such as quartz, feldspars, and amphiboles. Silica concentrations are about equal to the solubility of quartz (6 mg/L at $25 \mathrm{C}$ ), the most common mineral in Long Island aquifers. Silica concentrations listed in table 3 range from 5.9 to $10 \mathrm{mg} / \mathrm{L}$. The silica in pristine ground water makes up 20 to 33 percent (by weight) of the total dissolved-solids content.

Iron.-Iron concentrations of pristine ground water range from 0.01 to $3.2 \mathrm{mg} / \mathrm{L}$. Only 4 of 22 analyses given in table 3 show iron concentrations above $0.75 \mathrm{mg} / \mathrm{L}$, and all samples were from the Magothy and Lloyd aquifers. The dissolution of iron-bearing minerals, such as pyrite $\left(\mathrm{FeS}_{2}\right)$ and ferromagnesium silicates, is the most likely source of iron. Iron occurs in the upper glacial aquifer where dissolved oxygen is present. Under these oxidizing conditions, the iron-bearing minerals are generally stable because the iron is already in the ferric $\left(\mathrm{Fe}^{+3}\right)$ oxidation state (Vecchioli and others, 1974). In the deeper aquifers, where dissolved oxygen is lacking, reducing conditions cause the iron-bearing minerals to decompose, releasing ferrous iron $\left(\mathrm{Fe}^{+2}\right)$ into the ground water. Iron in ground water generally is in the ferrous state (Hem, 1970). Ground water in westem Long Island could be affected by contact with the iron-bearing Jameco Gravel.

Sulfate-Concentrations of sulfate in the upper glacial aquifer range from 2.6 to $12 \mathrm{mg} / \mathrm{L}$; those in five of six analyses were $8 \mathrm{mg} / \mathrm{L}$ or less. In shallow ground water, where dissolved oxygen is high, additional sulfate can be introduced by oxidation of pyrite and marcasite deposits. Sulfate concentrations in precipitation are about $4 \mathrm{mg} / \mathrm{L}$ 
(table 3) and, when concentrated by evapotranspiration, can account for most sulfate in solution.

As ground water moves downward along natural flow paths and enters a reducing environment, bacteria and organic matter can decrease sulfate concentrations through reactions that produce hydrogen sulfide and bicarbonate (Hem, 1970, p. 170). Sulfate concentrations in both the Magothy and Lloyd aquifers vary locally (table 3), ranging from 1.0 to $20 \mathrm{mg} / \mathrm{L}$ in the Magothy aquifer and from 0.8 to $20 \mathrm{mg} / \mathrm{L}$ in the Lloyd aquifer. These variations can be attributed to local variation in abundance of (1) bacteria, and (2) an organic food supply required for sulfate reduction. Several analyses show high bicarbonate concentrations in association with low sulfate concentration; this may indicate sulfate reduction. These variations also could result from local differences in the availability of pyrite as a source, or from the presence of water that entered the groundwater system before the mid-19th century, when sulfate concentrations in precipitation were lower than $4 \mathrm{mg} / \mathrm{L}$. Average sulfate concentrations appear to be higher in the Lloyd than in the Magothy, but this cannot be explained.

Hardness.-Water hardness is due to the presence of calcium and magnesium ions. Calcium and magnesium are present in several of the silicate minerals, such as feldspar (plagioclase), amphiboles, and pyroxenes, which are prevalent throughout the upper glacial aquifer (DeLaguna, 1964). The dissolution of these minerals is the most likely source of hardness in the ground water. The data in table 3 indicate that the hardness of ground water is extremely low, ranging from 1.5 to $21.9 \mathrm{mg} / \mathrm{L}$ as $\mathrm{CaCO}_{3}$. Natural hardness on westem Long Island could be higher than farther east because the Jameco aquifer contains abundant ferromagnesium minerals. Soren (1971) states that uncontaminated ground water in Queens contains less than $60 \mathrm{mg} / \mathrm{L}$ of hardness.

Sodium.-Sodium in ground water is derived from two sources-airborne salt from the sea, and aquifer materials. Salt spray from the ocean is blown landward, then carried to the water table with infiltrating precipitation. The sodium concentration of precipitation is about $1.5 \mathrm{mg} / \mathrm{L}$, which then increases through evaporation before it reaches the ground-water system. The rest of the sodium in the ground water is derived from the dissolution of minerals such as sodic feldspars in the soil zone and aquifer. DeLaguna (1964) concludes that the sodium in natural ground water on Long Island is probably derived in about equal amounts from sea salt in precipitation and the dissolution of minerals.

Chloride.-The source of practically all chloride in Long Island's ground water under predevelopment conditions was salt spray picked up by the wind and introduced into the groundwater system through infiltration of precipitation (Franke and McClymonds, 1972).

Jackson (1905, p. 29-31) estimates that the predevelopment concentrations of chloride in water on Long Island ranged from 3 to $8 \mathrm{mg} / \mathrm{L}$. This agrees with concentrations shown in table 3 for the eastem part of Long Island. Lusczynski and Swarzenski (1966, p. 19) assumed that, before development, ground water on Long Island contained less than $10 \mathrm{mg} / \mathrm{L}$ chloride. Chloride contamination was evident by the tum of this century in Kings and Queens Counties, where contamination from land surface began long before 1900. During 1898-1902, average chloride concentrations in the base flow of four streams in Queens County ranged from 8.8 to $12.4 \mathrm{mg} / \mathrm{L}$, whereas those in 12 streams in Nassau County ranged from 5.3 to $6.7 \mathrm{mg} / \mathrm{L}$ (Burr, Hering, and Freeman, 1904, p. 406-423). (Base-flow samples represent ground water that originated over large areas of the land surface and thus are reliable indicators of groundwater quality.)

Dissolved Solids. - The dissolved-solids concentration of water in all aquifers on Long Island is generally low compared to that in most other places and ranges from 15 to $53 \mathrm{mg} / \mathrm{L}$ (table 3 ). This is due to the lack of soluble minerals in the aquifer materials (Cohen and others, 1968). The highest dissolved-solids concentrations are in the Lloyd aquifer, probably because this water has traveled longer and farther through the groundwater system than water in the other aquifers and has had a greater contact time in which to react with the aquifer material. 
Table 3.- Chemical composition of Long Island ground water and precipitation under predevelopment conditions.

[Data from U.S. Geological survey records. mg/L, milligrams per liter; -, no analysis available; ND, not detected; methods of analysis and detection limits vary:

\begin{tabular}{|c|c|c|c|c|c|c|c|c|c|c|c|c|c|c|}
\hline $\begin{array}{c}\text { Source of } \\
\text { sample }\end{array}$ & $\begin{array}{l}\text { Date of } \\
\text { sample } \\
\text { colloction }\end{array}$ & $\begin{array}{l}\text { Sllica, } \\
\text { dis- } \\
\text { solved } \\
\left(\mathrm{mg}^{\prime} \mathrm{L}\right. \\
\text { as } \\
\left.\mathrm{siO}_{2}\right)\end{array}$ & $\begin{array}{c}\text { Iron } \\
\text { (mg/L } \\
\text { as Fe) }\end{array}$ & $\begin{array}{l}\text { Calcium, } \\
\text { dis- } \\
\text { solved } \\
\text { (mg/l } \\
\text { as Ca) }\end{array}$ & $\begin{array}{l}\text { Magne- } \\
\text { sium, } \\
\text { dis- } \\
\text { solved } \\
\text { (mg/L } \\
\text { as Mg) }\end{array}$ & $\begin{array}{c}\text { Hard- } \\
\text { ness } \\
\text { (mg/L } \\
\text { as } \\
\left.\mathrm{CaCO}_{3}\right)\end{array}$ & $\begin{array}{l}\text { Sodium, } \\
\text { dis- } \\
\text { solved } \\
\text { (mgll } \\
\text { as Na) }\end{array}$ & $\begin{array}{l}\text { Potas- } \\
\text { sium, } \\
\text { dis- } \\
\text { solved } \\
\text { (mg/L } \\
\text { as } K) \\
\end{array}$ & $\begin{array}{c}\text { Bicar- } \\
\text { bonate } \\
\text { (mgll } \\
\text { as } \mathrm{HCO}_{3} \text { ) } \\
\end{array}$ & $\begin{array}{c}\text { Sulfate, } \\
\text { dis- } \\
\text { solved } \\
(\mathrm{mgl} \\
\left.\text { as } \mathrm{SO}_{4}\right)\end{array}$ & $\begin{array}{l}\text { Chlo- } \\
\text { ride, } \\
\text { dis- } \\
\text { solved } \\
\text { (mg/L } \\
\text { as Cl) } \\
\end{array}$ & $\begin{array}{l}\text { Nitrate, } \\
\text { dis- } \\
\text { solved } \\
\text { (mg/L } \\
\text { as } \mathrm{No}_{3} \text { ) }\end{array}$ & $\begin{array}{l}\text { Total } \\
\text { dis- } \\
\text { solved } \\
\text { solids } \\
\text { (mg/L) }\end{array}$ & $\underset{\text { (units) }}{\mathrm{pH}}$ \\
\hline \multicolumn{15}{|c|}{ PRECIPITATION } \\
\hline Siation A & $\underset{3 / 66}{11 / 65}$ to & - & - & 0.5 & 0.3 & 2.5 & 1.6 & 0.1 & - & 3.8 & 2.7 & 0.8 & 10. & 4.5 \\
\hline Station B & $\begin{array}{l}8 / 31 / 65 \text { to } \\
8 / 30 / 65\end{array}$ & - & - & 3 & .4 & 2.4 & 1.5 & 2 & - & 4. & 2.2 & .4 & - & - \\
\hline \multicolumn{15}{|c|}{$\begin{array}{l}\text { GROUND WATER } \\
\text { Upper glaciai aquifer }\end{array}$} \\
\hline $\begin{array}{l}\text { S } 3197 \\
\mathbf{S} 518 \\
\mathbf{S} 6405 \\
\mathbf{S} 6432 \\
\mathbf{S} 9141 \\
\mathbf{S} \mathbf{9 1 4 2}\end{array}$ & $\begin{array}{r}4 / 16 / 48 \\
10 / 15 / 48 \\
12 / 17 / 48 \\
12 / 17 / 48 \\
2 / 13 / 50 \\
2 / 13 / 50\end{array}$ & $\begin{array}{l}9.1 \\
6 . \\
5.9 \\
9.6 \\
6.1 \\
6 .\end{array}$ & $\begin{array}{l}0.37 \\
.01 \\
.19 \\
.75 \\
.41 \\
.28\end{array}$ & $\begin{array}{l}1.6 \\
1.5 \\
2.1 \\
2.1 \\
1.3 \\
1.4\end{array}$ & $\begin{array}{l}1.2 \\
1.3 \\
1.6 \\
1.1 \\
1.3 \\
2 .\end{array}$ & $\begin{array}{r}8.1 \\
11.8 \\
9.8 \\
8.6 \\
11.7\end{array}$ & $\begin{array}{l}3.9 \\
3.2 \\
4.7 \\
3.8 \\
5.4 \\
5.5\end{array}$ & $\begin{array}{r}.5 \\
.6 \\
.9 \\
.4 \\
1.1 \\
1.4\end{array}$ & $\begin{array}{l}8 . \\
4 . \\
1 . \\
11 . \\
10 . \\
8 .\end{array}$ & $\begin{array}{l}4 . \\
6 . \\
12 . \\
2.6 \\
6.6 \\
8 .\end{array}$ & $\begin{array}{l}4 . \\
5 . \\
6 . \\
4.4 \\
5.9 \\
6.9\end{array}$ & $\begin{array}{l}2 \\
.1 \\
.1 \\
.1 \\
.1 \\
2\end{array}$ & $\begin{array}{l}28 . \\
28 . \\
36 . \\
29 . \\
32 . \\
34 .\end{array}$ & $\begin{array}{l}6.3 \\
6.5 \\
5.5 \\
6.7 \\
6.9 \\
6.5\end{array}$ \\
\hline \multicolumn{15}{|c|}{ Magothy aquifer } \\
\hline $\begin{array}{r}\mathbf{N} 2780 \\
\mathbf{N} 3866 \\
\mathbf{N} 4149 \\
\mathbf{N} 7887 \\
\mathbf{N} 7889 \\
\mathbf{S} \\
\mathbf{S} \\
\mathbf{S} \\
\mathbf{S} \\
\mathbf{5 1} \\
\mathbf{S} 24769 \\
\mathbf{S 2 4 7 7 0}\end{array}$ & $\begin{array}{c}c- \\
10 / 14 / 52 \\
8 / 30 / 53 \\
c- \\
c- \\
5 / 02 / 35 \\
10 / 26 / 32 \\
10 / 10 / 32 \\
7 / 07 / 65 \\
8 / 10 / 65\end{array}$ & $\begin{array}{c}7.4 \\
8.8 \\
6.5 \\
7.5 \\
7.5 \\
- \\
- \\
5.9 \\
6.4\end{array}$ & $\begin{array}{l}.6 \\
2.9 \\
.61 \\
.18 \\
25 \\
. .98 \\
.13 \\
.31 \\
.14\end{array}$ & $\begin{array}{c}.34 \\
1.3 \\
1.5 \\
1.08 \\
.39 \\
1.0 \\
1.0 \\
2.0 \\
1.4 \\
2.1\end{array}$ & $\begin{array}{l}.17 \\
.4 \\
.1 \\
24 \\
.30 \\
- \\
- \\
-.6 \\
2\end{array}$ & $\begin{array}{l}1.5 \\
5 . \\
2.0 \\
3.7 \\
2.2 \\
4 . \\
5 \\
10 . \\
6 . \\
6 .\end{array}$ & $\begin{array}{c}3.7 \\
3.9 \\
2.4 \\
3.9 \\
4.0 \\
- \\
- \\
3.7 \\
3.0\end{array}$ & $\begin{array}{l}60 \\
5 \\
3 \\
.68 \\
50 \\
- \\
- \\
.6 \\
3\end{array}$ & $\begin{array}{c}6.0 \\
6.0 \\
2.6 \\
7.5 \\
5.0 \\
10 . \\
22 . \\
20 . \\
9 . \\
8 .\end{array}$ & $\begin{array}{c}4.1 \\
5.0 \\
1.6 \\
4.0 \\
3.9 \\
20 . \\
10 . \\
1.0 \\
3.2 \\
2.0\end{array}$ & $\begin{array}{l}3.75 \\
3.5 \\
2.5 \\
3.78 \\
3.75 \\
7.0 \\
4.0 \\
6.8 \\
4.0 \\
3.5\end{array}$ & $\begin{array}{l}\text { ND } \\
.31 \\
.1 \\
\text { ND } \\
N D \\
N D \\
.04 \\
.04 \\
N D \\
.1\end{array}$ & $\begin{array}{c}23 . \\
28 . \\
15 . \\
24 . \\
23 . \\
= \\
= \\
24 . \\
16 .\end{array}$ & $\begin{array}{l}5.6 \\
6.0 \\
5.8 \\
5.58 \\
5.25 \\
:- \\
- \\
6.2 \\
6.2\end{array}$ \\
\hline \multicolumn{15}{|c|}{ Lloyd aquifer } \\
\hline $\begin{array}{rr}\mathbf{N} & 67 \\
\mathbf{N} & 1618 \\
\mathbf{N} & 2602 \\
\mathbf{N} & 3355 \\
\mathbf{N} & 3448 \\
\mathbf{N} & 3687 \\
\mathbf{N} & 4405 \\
\mathbf{N} & \mathbf{5 2 2 7} \\
\mathbf{S} 6409 \\
\mathbf{S} & 6434\end{array}$ & $\begin{array}{r}8 / 02 / 62 \\
4 / 30 / 57 \\
5 / 26 / 57 \\
6 / 25 / 51 \\
7 / 31 / 62 \\
1 / 16 / 52 \\
9 / 15 / 54 \\
11 / 14 / 61 \\
11 / 08 / 48 \\
6 / 02 / 49\end{array}$ & $\begin{array}{c}8.2 \\
7.5 \\
8.3 \\
9.2 \\
8.0 \\
10 . \\
8.2 \\
-.5 \\
7.5 \\
8.4\end{array}$ & $\begin{array}{c}3.2 \\
.14 \\
N \overline{0} \\
-57 \\
.5 \\
1.5 \\
1.3 \\
.47\end{array}$ & $\begin{array}{r}.9 \\
2.6 \\
1.1 \\
2.2 \\
1.8 \\
2.0 \\
.9 \\
1.5 \\
4.3\end{array}$ & $\begin{array}{r}.8 \\
1.4 \\
.6 \\
.8 \\
2.7 \\
.7 \\
.7 \\
1.6 \\
2.7\end{array}$ & $\begin{array}{c}6.0 \\
12 . \\
5 \\
9 . \\
16.0 \\
8 . \\
8 . \\
4.3 \\
10.3 \\
21.8\end{array}$ & $\begin{array}{l}3.2 \\
2.9 \\
2.8 \\
3.8 \\
8.9 \\
7.6 \\
-.2 \\
6.2 \\
4.4\end{array}$ & $\begin{array}{c}.4 \\
.7 \\
.7 \\
.6 \\
12 \\
\text { ND } \\
.5 \\
.5 \\
2.2 \\
2.4\end{array}$ & $\begin{array}{c}2.0 \\
12 . \\
8 . \\
13 . \\
\text { ND } \\
1 \\
6 . \\
4 . \\
16 . \\
24 .\end{array}$ & $\begin{array}{r}6.5 \\
5.0 \\
.8 \\
.8 \\
20 . \\
16 . \\
15 . \\
14 . \\
3.5 \\
12 .\end{array}$ & $\begin{array}{c}4.2 \\
3.8 \\
3.8 \\
4.5 \\
8.2 \\
5.0 \\
10 \\
2 . \\
4.1 \\
5.6\end{array}$ & $\begin{array}{l}\text { ND } \\
\text { ND } \\
.09 \\
N D \\
N D \\
N D \\
.09 \\
.1 \\
.1 \\
.1\end{array}$ & $\begin{array}{l}25 . \\
30 . \\
22 . \\
28 . \\
52 . \\
53 . \\
36 . \\
32 . \\
53 .\end{array}$ & $\begin{array}{l}5.1 \\
6.00 \\
6.10 \\
6.80 \\
4.5 \\
4.80 \\
6.80 \\
5.3 \\
6.4 \\
6.5\end{array}$ \\
\hline
\end{tabular}

a Average of six composite monthly samples from gage near Brookhaven National Laboratory, October 1965 through March 1966. From Franke and McClymonds (1972, p. 36.)

b Composite of 1.02 inches of precipitation collected from gage at Upton, N.Y. Analyses by U.S. Geological Survey. Data from U.S. Geological Survey (1965).

c From Vecchioli and others (1974, p. C25.) 


\section{EFFECTS OF URBANIZATION ON THE HYDROLOGIC SYSTEM}

Ground water on western Long Island was developed rapidly in the early 19th century along with the rapid population growth in Kings and western Queens Counties. The early residents obtained water from shallow wells and from streams (which are primarily base flow) and springs and returned most of it to the aquifer through septic systems. This withdrawal and return probably caused only minor changes in the water-table configuration and in shallow groundwater flow patterns.

As the demand for public and industrial water supply increased, the number of wells and the quantity pumped also increased, increasing the infiltration of wastewater contaminants introduced to the ground-water system. In the mid-19th century, storm and sanitary sewers were installed in Kings and discharged wastewater to the sea. Although this prevented contaminants from entering the ground-water system, it also diverted a large quantity of water that would have recharged the ground-water system. At the same time, the ever-increasing amounts of paved land surface reduced the area available for infiltration of precipitation, further decreasing recharge. By the 1930's, these changes, along with the continuous increase in industrial and water-supply pumpage, caused severe declines in the water table and in the hydraulic head in the deeper aquifers. Declines in the water-table altitude caused many lakes and streams to disappear and severely decreased the flow in remaining streams. At the same time, the decrease in hydraulic head caused intrusion of saltwater into the aquifers in nearshore areas.

\section{Development of Ground-Water Supply}

Pumping for industrial and public supply in the 20th century has imposed a severe stress on the western part of the Long Island ground-water system. Ground water pumped and lost either by evaporation or discharge to the sea is considered consumptive (net) pumpage and is a net draft on the ground-water system.

Virtually all of the ground water pumped in western Long Island is lost either through evaporation or to combined (storm and sanitary) sewers with ocean outfall. Developed parts of Kings and Queens had an extensive sewer network by the turn of this century. As a result, only a small, undeter- mined fraction of pumped ground water infiltrated back to the ground-water system in unpaved areas and from leaking sewer and water-supply lines.

\section{History of Ground-Water Development}

Public-supply and industrial pumpage from 1904-83 are plotted in figure 4. (No data are available for industrial pumpage in Queens County before 1948; it probably was considerably less than in Kings County but followed similar trends.) Pumpage and ground-water development through the 20th century are summarized in four general phases, described below.

1900-17.-By 1900, the ground-water reservoir of western Long lsland was used extensively for both public-supply and industrial uses. Johnson and Waterman (1952, p. 7) estimate that in $1904,6.4 \mathrm{Mgal} / \mathrm{d}$ was obtained from surface storage of ground-water-fed springs and streams in Queens County, and 77.4 Mgal/d was obtained from surface storage from nearby Nassau County.

By 1904, pumpage for public supply had reached $14 \mathrm{Mgal} / \mathrm{d}$ in Kings County and $28 \mathrm{Mgal} / \mathrm{d}$ in Queens, most of which was used in Kings County. The average pumpage for public supply during 1909-16 was $30 \mathrm{Mgal} / \mathrm{d}$ in Kings County and $58 \mathrm{Mgal} / \mathrm{d}$ in Queens County (fig. 4). Industrial pumpage in 1904, although only a few million gallons per day in Queens, was $14 \mathrm{Mgal} / \mathrm{d}$ in Kings County and increased markedly in both counties thereafter.

In 1917, New York City water tunnel 1 was completed, and surface water from reservoirs in upstate New York was transported to the watersupply-distribution system in Kings and Queens. This water replaced a significant amount of ground-water pumpage, as indicated in figure 4. The City of New York, Department of Water Supply, Gas, and Electricity, which had pumped more than $14 \mathrm{Mgal} / \mathrm{d}$ in Kings County and 40 $\mathrm{Mgal} / \mathrm{d}$ in Queens County during the preceding 10 years, all but ceased pumping in 1917.

1918-30. - The post-World War I period in westem Long Island was marked by a consistent increase in consumptive ground-water use for both public supply and industrial use. After the abrupt reduction in pumpage for public supply in 1917, continued demand resulted in an increase in 
public-supply pumpage from $13 \mathrm{Mgal} / \mathrm{d}$ in Kings County and $23.1 \mathrm{Mgal} / \mathrm{d}$ in Queens in 1918 to 29.2 $\mathrm{Mgal} / \mathrm{d}$ and $62.0 \mathrm{Mgal} / \mathrm{d}$, respectively, in 1931 (fig. 4). Industrial pumpage also continued to increase and, by 1930 , had exceeded $50 \mathrm{Mgal} / \mathrm{d}$ in Kings County and was probably about $20 \mathrm{Mgal} / \mathrm{d}$ (estimated by the authors) in Queens.

1930-46.-Pumping for public supply during this period was relatively constant in Kings County but ranged from more than $\mathbf{6 0}$ to less than $\mathbf{4 0}$ $\mathrm{Mgal} / \mathrm{d}$ in Queens. In 1936, tunnel 2 was completed and increased the capacity to supply upstate surface water to Kings and Queens. The effect is not evident in ground-water pumping data for Kings and may have caused only a minor decrease in Queens (fig. 4). Much of the imported water probably was used for conversion of new areas to public supply.

The 1930's brought a noticeable decline in industrial pumpage (fig. 4) for two major reasons:
1. Concern over the extensive use of ground water by industry prompted the adoption of the New York State Water Conservation Law of 1933, which required that water pumped at a rate greater than $70 \mathrm{gal} / \mathrm{min}(0.1 \mathrm{Mgal} / \mathrm{d})$ be reinjected into the source aquifer after use.

(Ground water pumped for industrial use and returned to the source aquifer is not included in the net pumpage shown in fig. 4.) Leggette and Brashears (1938, p. 413) estimate that only one recharge well was operating in western Long Island at the end of 1933 , but by 1937 , the number had increased to 105 . The average daily rate of recharge reached a high of 22 $\mathrm{Mgal} / \mathrm{d}$ in the air-conditioning season during these years but maintained an average annual rate of about $12 \mathrm{Mgal} / \mathrm{d}$.

2. The widespread adoption of electric refrigeration severely reduced the quantity of water pumped for ice making. Lusczynski (1952,
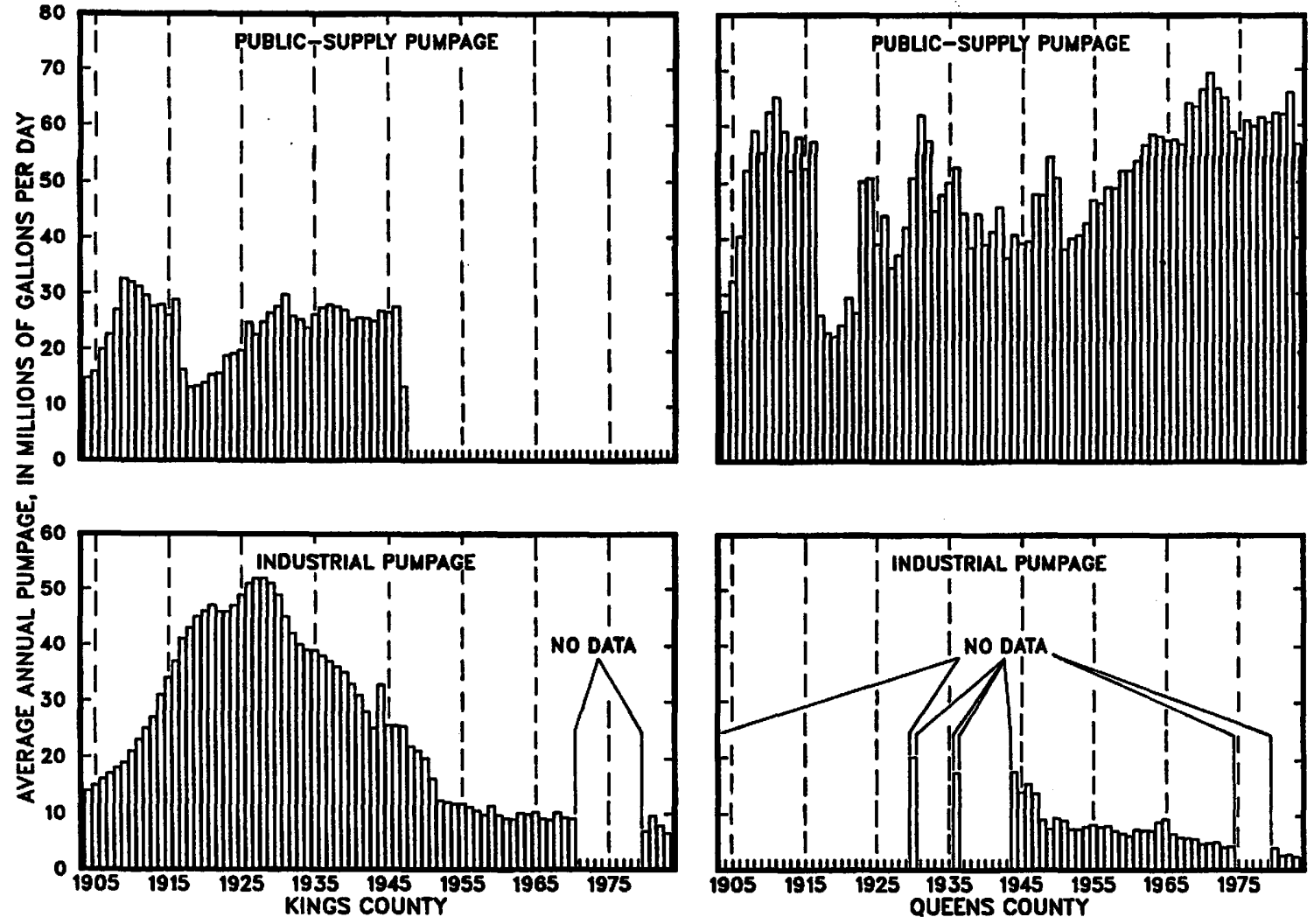

Figure 4. Annual average pumpage for industrial and public supply in Kings and Queens Counties, 1904-83. (Compiled from Johnson and Waterman, 1952; Thompson and Leggette, 1936, Suter, 1937, and New York State Department of Environmental Conservation.) 
p. 4) states that the quantity of water pumped for ice-making during 1936-47 decreased from $18 \mathrm{Mgal} / \mathrm{d}$ to $4 \mathrm{Mgal} / \mathrm{d}$.

During World War II (1940-45), industrial pumpage increased slightly in Kings County; a similar increase was likely in Queens County.

1947 to 1983. - In 1947, New York City stopped all public-supply pumping in Kings County, primarily because of saltwater intrusion, but pumping for public supply continued in Queens, where it increased from $45 \mathrm{Mgal} / \mathrm{d}$ in 1950 to more than $60 \mathrm{Mgal} / \mathrm{d}$ in the 1970's (fig. 4). The trend of pumping in Queens has been to abandon wells showing contamination and to install new ones eastward and farther inland, where water levels are higher.

Pumpage declined in 1974 (fig. 4), when all pumping for public supply $(10 \mathrm{Mgal} / \mathrm{d})$ in the
Woodhaven franchise area (fig.6A) of the New York Water Service Corporation (NYWSC) was halted as a result of saltwater intrusion. Industrial pumpage declined gradually in both counties and fell below $10 \mathrm{Mgal} / \mathrm{d}$ in Kings and $3 \mathrm{Mgal} / \mathrm{d}$ in Queens.

\section{Development of Individual Aquifers}

Annual average pumpage for public supply in Kings and Queens during 1904-83 is plotted by aquifer in figure 5 . Such a breakdown for industrial pumpage is unavailable, but most pumping for industrial purposes probably has been from the upper glacial (water-table) aquifer.

Early in this century (1904-17), most groundwater pumpage was derived from the upper glacial aquifer; it attained a maximum of $70 \mathrm{Mgal} / \mathrm{d}$ in 1910 (24.1 Mgal/d in Kings and 46.0 Mgal/d in
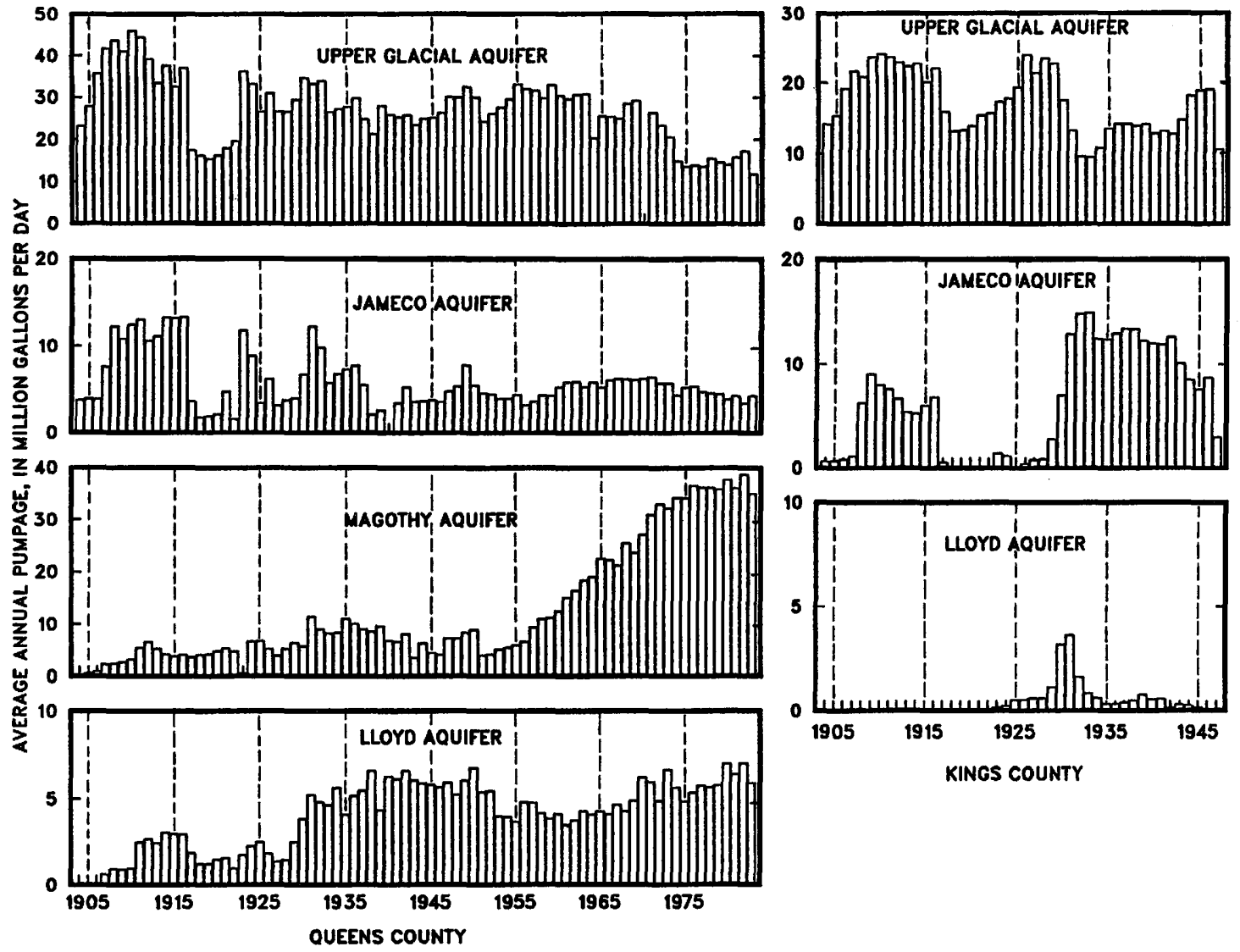

Figure 5. Annual average public-supply pumpage from individual aquifers in Queens County (lefi) and Kings County (right), 1904-83. (Compiled from Johnson and Waterman, 1952, and New York State Department of Environmental Conservation: pumpage records obtained from the New York Water Service Corporation and Jamaica Water Supply Company.) 
Queens). At the same time, pumping from the Jameco was $20.5 \mathrm{Mgal} / \mathrm{d}$ (8 Mgal/d in Kings and 12.5 Mgal/d in Queens), and pumping from the Magothy aquifer was about $5 \mathrm{Mgal} / \mathrm{d}$. (No water was pumped from the Magothy aquifer in Kings County throughout 1904-83 because this aquifer is not extensive there.) Pumping from the Lloyd aquifer started as early as 1905 but reached a maximum of only about $3 \mathrm{Mgal} / \mathrm{d}$ during 1904-17.

Pumping from the upper glacial and Jameco aquifers decreased substantially in 1917 with the completion of the first water tunnel to bring upstate surface water to the city, but in the following years, pumping from all aquifers gradually increased. A distinct shift in pumping from the upper glacial to the Jameco aquifer in Kings County is evident during 1928-33 (fig. 5); pumpage from the upper glacial aquifer decreased from $23.4 \mathrm{Mgal} / \mathrm{d}$ in 1928 to $9.5 \mathrm{Mgal} / \mathrm{d}$ in 1933 , while pumping from the Jameco aquifer increased from $0.8 \mathrm{Mgal} / \mathrm{d}$ to 14.9 $\mathrm{Mgal} / \mathrm{d}$. This shift was in response to saltwater intrusion, which by 1947 had caused the cessation of all public-supply pumping in Kings County.

A similar shift from the upper glacial aquifer to the Magothy aquifer occurred in Queens County during 1955-76, when pumping from the upper glacial aquifer decreased from $33.0 \mathrm{Mgal} / \mathrm{d}$ to 13.9 $\mathrm{Mgal} / \mathrm{d}$, and pumping from the Magothy aquifer increased from $5.9 \mathrm{Mgal} / \mathrm{d}$ to $36.5 \mathrm{Mgal} / \mathrm{d}$. This shift also was duc, at least in part, to saltwater intrusion, which ultimately caused the shutdown of pumping in the Woodhaven Franchise area of the NYWSC. (See fig. 6A.)

Pumping from the Lloyd and Jameco aquifers in Queens County has remained relatively stable since the 1930's, and pumping from the Lloyd in Kings County has been almost negligiblo-it exceeded $1 \mathrm{Mgal} / \mathrm{d}$ only during 1929-32, with a maximum of $3.6 \mathrm{Mgal} / \mathrm{d}$ in 1931.

\section{Declines in Water Levels}

The most marked effect of urbanization on the hydrologic system of western Long Island has been a decline in the water table and in the potentiometric surface of the deeper aquifers. The configuration of the water table before development was discussed previously (see fig. 3); water-table maps for subsequent years (figs. 6A-6E) depict the changes resulting from urbanization and related stresses during the 20th century.
By 1936, the water table showed severe declines resulting from heavy pumping and loss of recharge. (Compare figs. 3 and 6A.) An asymmetric cone of depression in northern Kings County, an area of extensive industrial pumping at that time, reached a depth of $35 \mathrm{ft}$ below sea level and extended into westem Queens County.

The decline in industrial pumping that started around 1930 (fig. 4) resulted in some recovery of the water table by 1943 (fig. 6B). (Note that the water table in northern Queens County was not contoured, possibly because, at that time, Jacob (1945) was uncertain whether anomalous high water levels were perched or were the actual watertable surface.) The water-table configuration of 1943 showed a partial recovery in northern Kings and westem Queens Counties.

After the cessation of pumping for public supply in Kings in 1947, the water table recovered further. The water-table configuration of 1951 (fig. 6C) shows a rise in the southern half of Kings County to altitudes above sea level, and the cone of depression in the north is smaller and shallower than in 1936 (fig. 6A).

By 1961, the water table (fig. 6D) had risen to above sea level throughout Kings County except in a small area in the north. Perlmutter and Soren $(1962$, p. 128) report that the dewatering rates at several subway stations in Flatbush increased from less than $20 \mathrm{gal} / \mathrm{min}$ in 1947 to as much as 1,000 $\mathrm{gal} / \mathrm{min}$ by 1961 .

A sizable cone of depression is evident in the Woodhaven franchise area in Queens County, where pumping increased in response to a continuing rise in demand. The cone of depression extended into Jamaica, where pumpage by the Jamaica Water Supply Company in 1961 was nearly $50 \mathrm{Mgal} / \mathrm{d}$. Although the cone of depression in 1961 was not as deep as that in Kings County in the 1930's (fig. 6A), the initial water levels in Queens County were $20 \mathrm{ft}$ higher than in Kings, so that the respective declines represent similar losses in ground-water storage.

By 1974, the water table had recovered further in Kings County (fig. 6E), and the cone of depression in Queens had shifted from Woodhaven, where pumping stopped in 1974, eastward to Jamaica, where the Jamaica Water Supply Company was pumping about $60 \mathrm{Mgal} / \mathrm{d}$. Water levels in this cone of depression represent a regional drawdown of about $35 \mathrm{ft}$ from water levels in 1903 (fig. 3). 
Similar declines in the potentiometric surface of the deeper aquifers have resulted from increased pumping and urbanization. Historical data on the potentiometric surface of these aquifers are sparse, but recent water-level records for wells screened in the deeper aquifers confirm that drawdown propagates rapidly from one aquifer to the next in areas where confining units are absent. Pumping confined parts of the deeper aquifers produces a cone of depression within the pumped aquifer that is broader than the one in the water-table aquifer. Because confined storage coefficients are typically much lower than the specific yield of the watertable aquifer, the transient response to stress is more rapid in the deeper aquifers. Also, the absence of local stream and surface-water boundaries in confined aquifers forces propagation of drawdown to more distant boundaries.

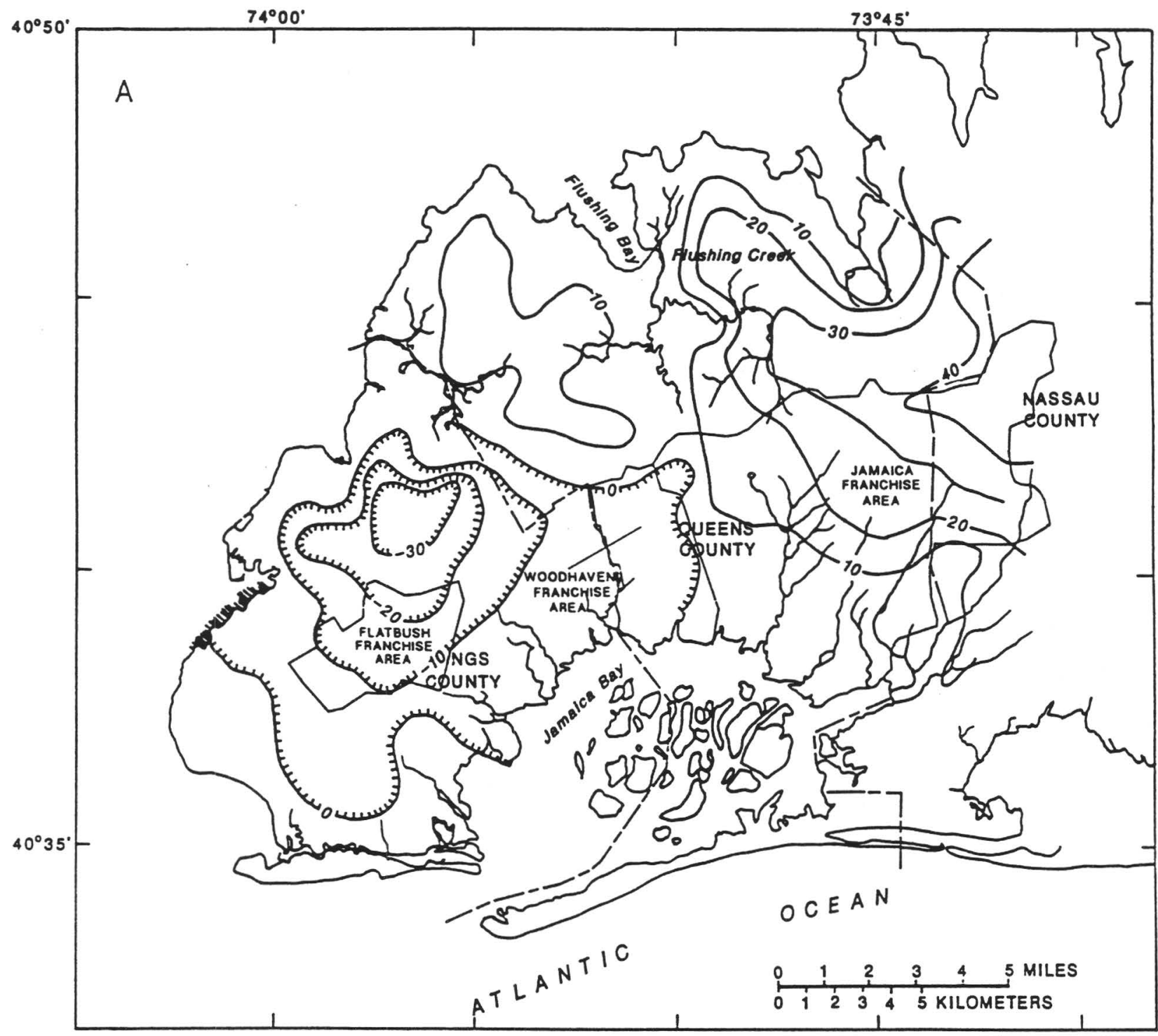

EXPLANATION WATER-TABLE CONTOUR- Shows altitude of water table. Contour
interval 10 feet. Datum is sea level. Hachures indicate depression

Figure 6A. Water-table configuration in 1936. (Modified from Suter, 1937, fig. 26.) 


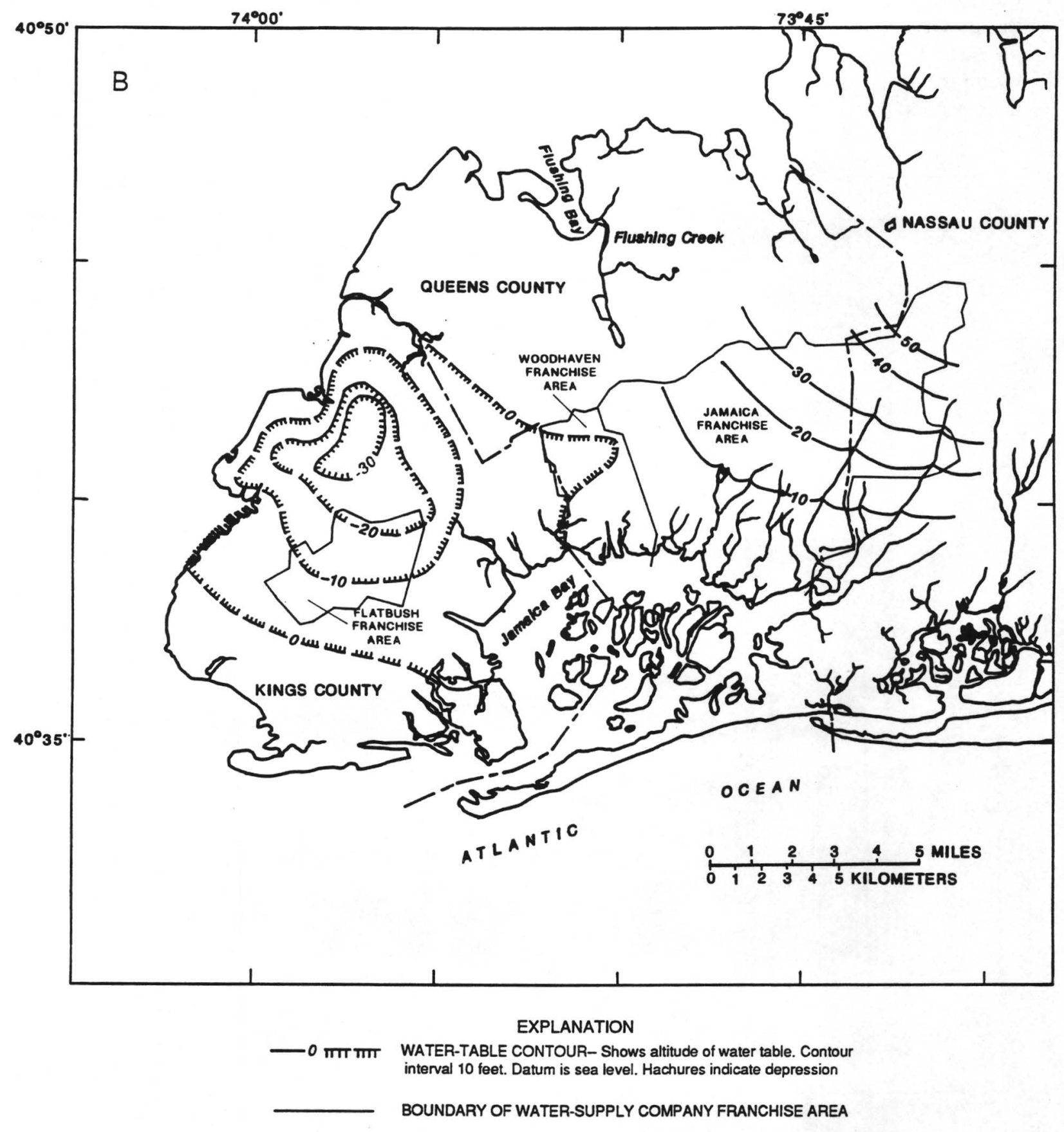

Figure 6B. Water-table configuration in 1943. (Water levels were measured in late May.). (Modified from Jacob, 1945, pl. 1.) 


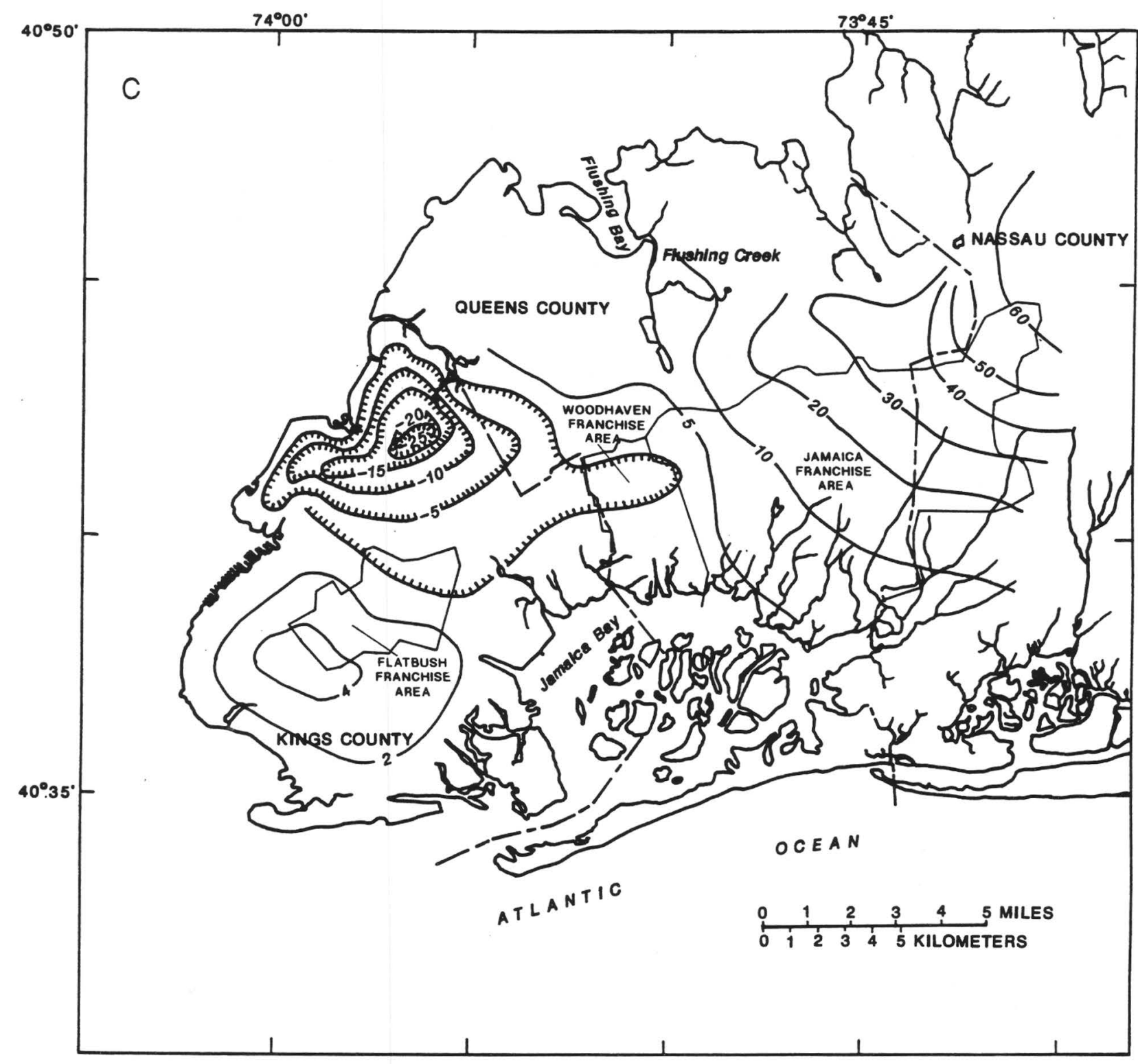

EXPLANATION

- $0 \mathrm{mIT}$ mIT WATER-TABLE CONTOUR-Shows altitude of water table. Contour interval 10 feet. Datum is sea level. Hachures indicate depression

BOUNDARY OF WATER-SUPPLY COMPANY FRANCHISE AREA

Figure 6C. Water-table configuration in 1951. (Water levels were measured in January. Modified from Lusczynski and Johnson, 1951, pl. 1.), 


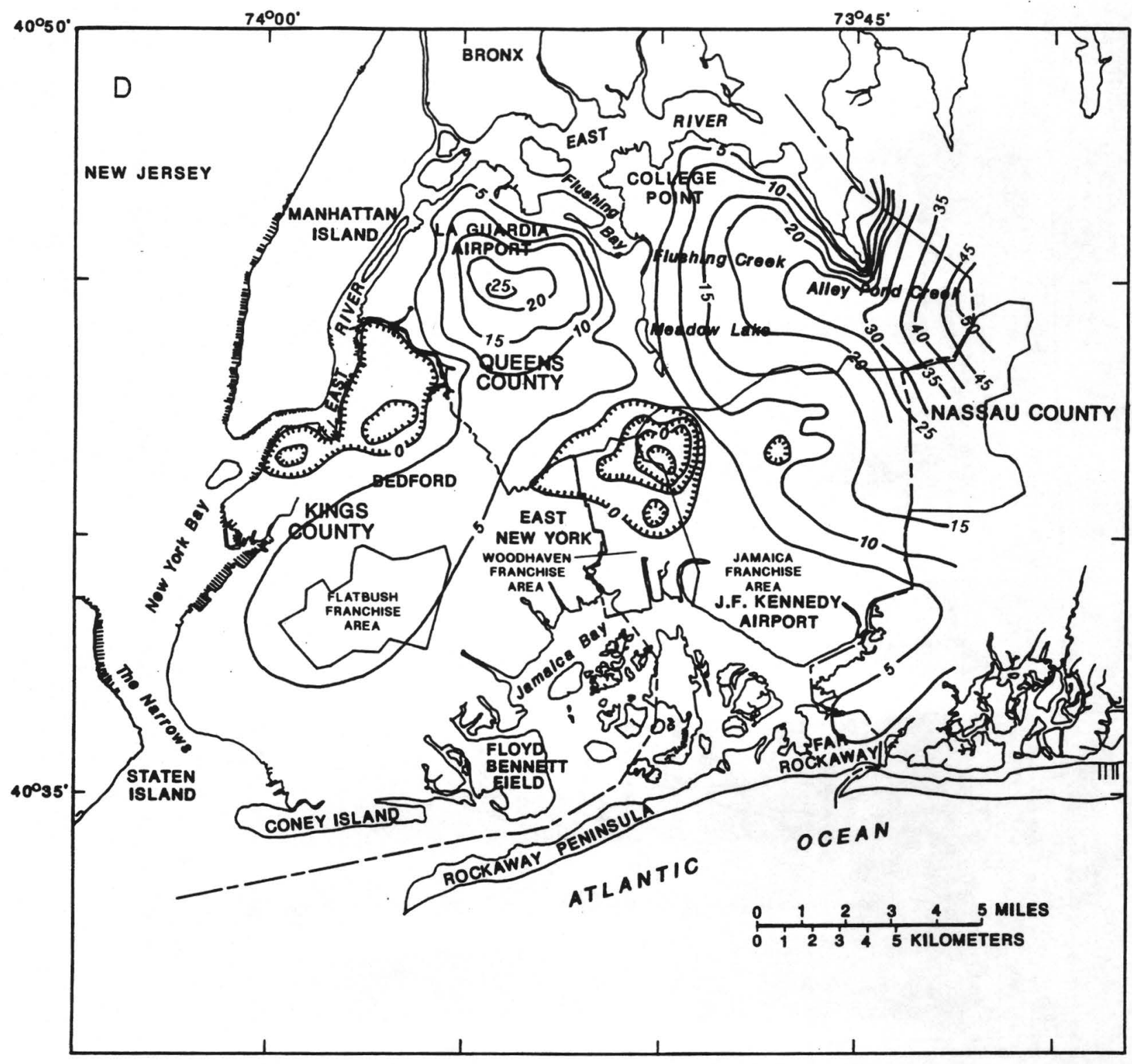

EXPLANATION

- $0 \mathrm{~m} \pi \mathrm{m}$ WATER-TABLE CONTOUR-Shows altitude of water table. Contour interval 10 feet. Datum is sea level. Hachures indicate depression

BOUNDARY OF WATER-SUPPLY COMPANY FRANCHISE AREA

Figure 6D. Water-table configuration in 1961. (Water levels were measured in December. Modified from Perlmutter and Soren, 1962, fig. 1B.) 


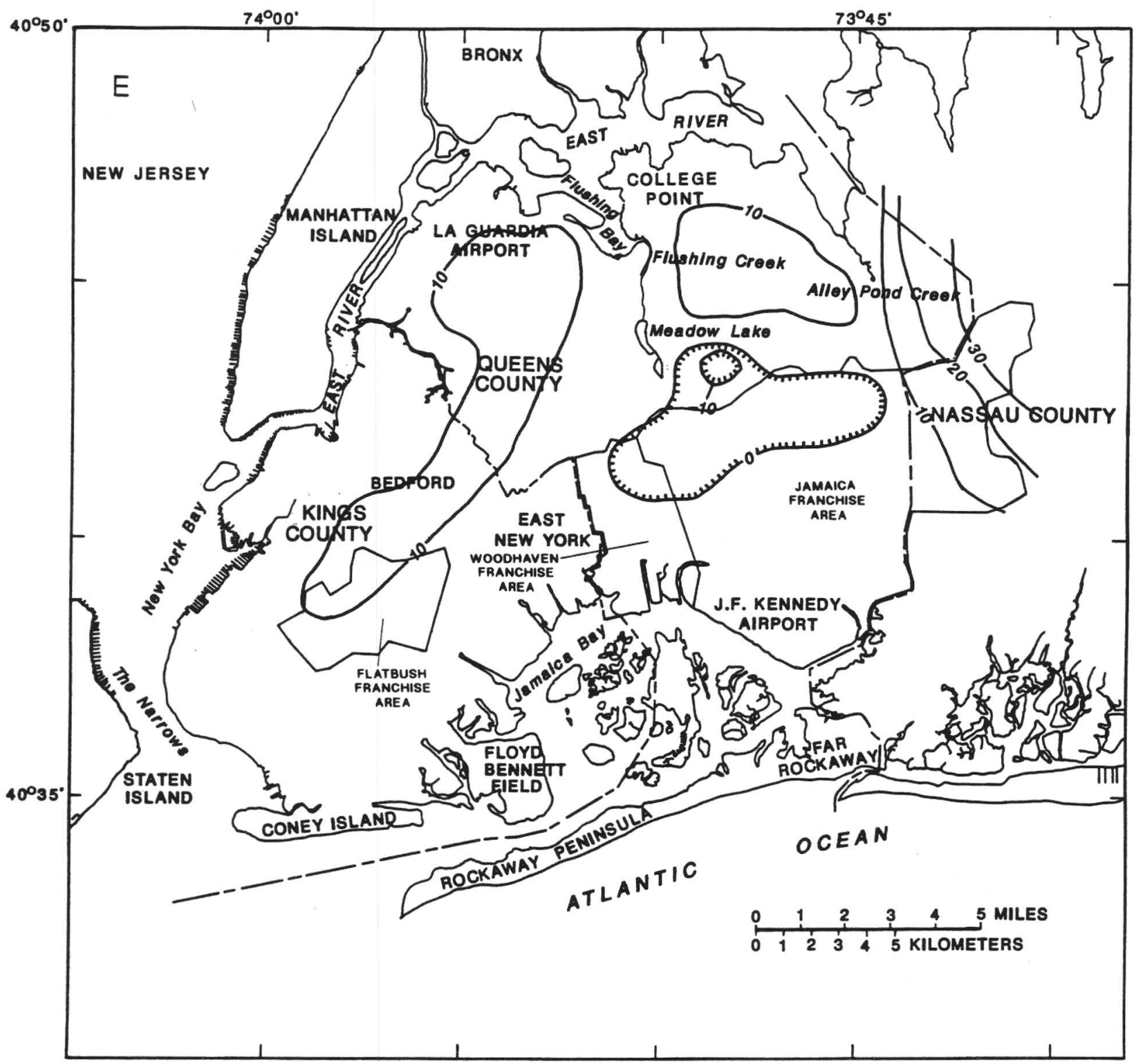

\section{EXPLANATION}

- $0 \mathrm{mIT}$ TIT WATER-TABLE CONTOUR-Shows altitude of water table. Contour interval 10 feet. Datum is sea level. Hachures indicate depression

BOUNDARY OF WATER-SUPPLY COMPANY FRANCHISE AREA

Figure 6E. Water-table configuration in 1974. (Water levels were measured in March. Modified from Koszalka, 1975, pl. 3.) 


\section{Deterloratlon of Ground-Water Quality}

In addition to lowering ground-water levels in Kings and Queens Counties, urbanization and development of the ground-water resources have caused serious deterioration of ground-water quality. The most striking example has been the encroachment of saltwater from surrounding saltwater boundaries in response to excessive drawdown. Other sources of contamination, some of which were present from the early stages of development, include fertilizers, underground sewagedisposal systems, landfills, large cemeteries, road salts, leaking sewers, chemical spills at land surface, and industrial and other wastewater impoundments.

Historical water-quality data are sparse, but chloride and nitrate data were collected as far back as 1900 and are used here to give an indication of changes in ground-water quality during this century. Elevated chloride concentrations accompanied by very low nitrate concentrations are indicative of seawater encroachment, whereas elevated nitrate and chloride together are considered to indicate contamination from land surface.

Nitrate and chloride are among the earliest contaminants to be introduced to the ground-water system. They first entered the system on a wide- spread basis about 200 years ago as fertilizers and domestic wastes and are considered indicators of water that has been affected by human activities.

\section{Chloride}

Encroachment of saline ground water has affected public-supply wells in westem Long Island since the tum of this century. Spear (1912) shows the increase in chloride in water pumped from driven wells at the Shetucket pumping station near Jamaica Bay during 1897-1905 (fig. 7). Chloride concentrations rose to $500 \mathrm{mg} / \mathrm{L}$ in these 9 years. Once saline ground water was drawn into the area of the pumping wells, even a significant reduction in pumping rate did little to improve water quality.

Later, pumping wells were installed inland to avoid the saline ground water. By the early 1930's, however, high pumping rates had caused saltwater intrusion even in inland areas. A sharp increase in chloride concentration in water from two publicsupply wells screened in the upper glacial aquifer in the Flatbush franchise area occurred during the 1940's (fig. 8A). Saline ground water probably was drawn this far inland from beneath surrounding tidal waters by the expanding cone of depression that extended to shore areas. The migration of saltwater so far inland during this period probably
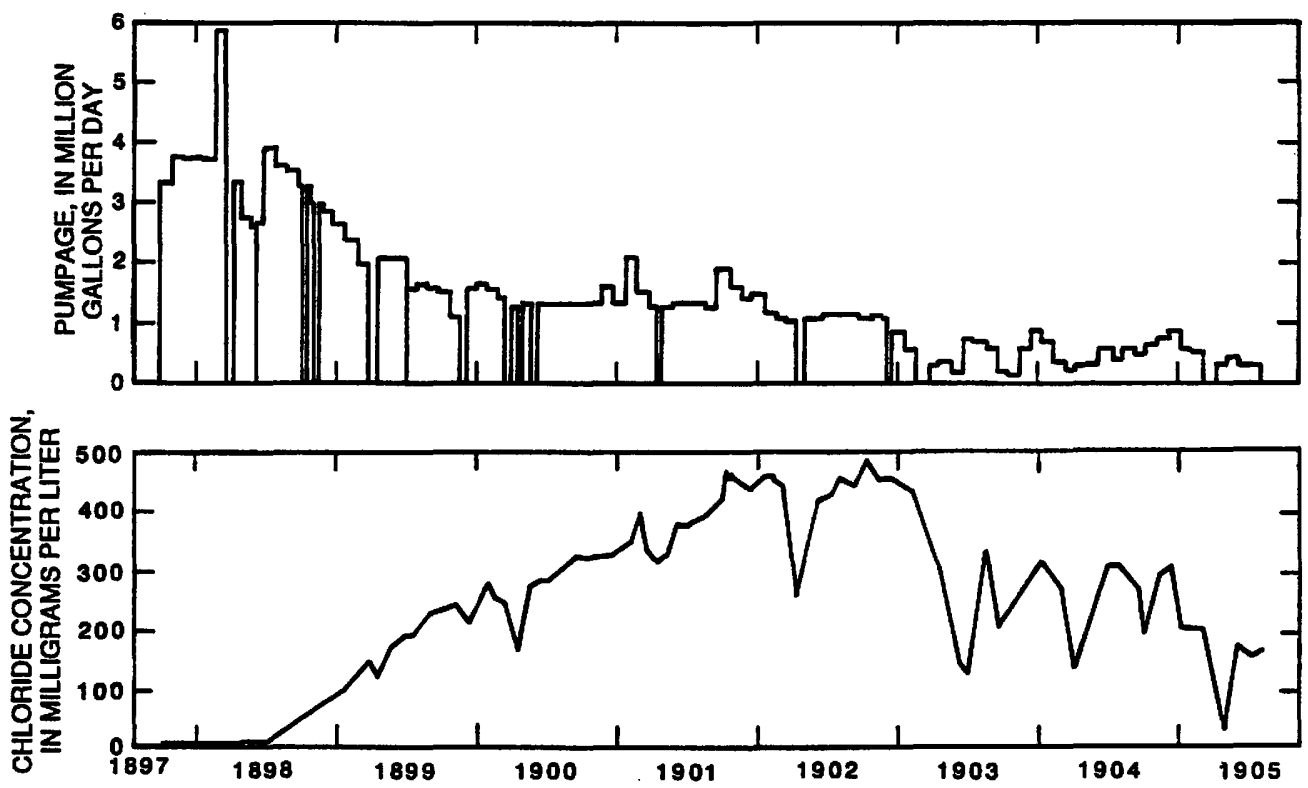

Figure 7. Average chloride concentration and total pumpage from eight driven wells at the Shetucket pumping station, 1897-1905. (From Spear, 1912, sheet 12.) 
indicates that saline ground water moved through preferential and highly conductive pathways. The water-table configuration of 1903 (fig. 3) shows seaward gradients; that of 1936 (fig. 6A) indicates a change to flat or slightly landward gradients near much of the shore in Kings County, which would accelerate saltwater encroachment. Pumping was stopped in Flatbush wells in 1947 (see fig. 8A).
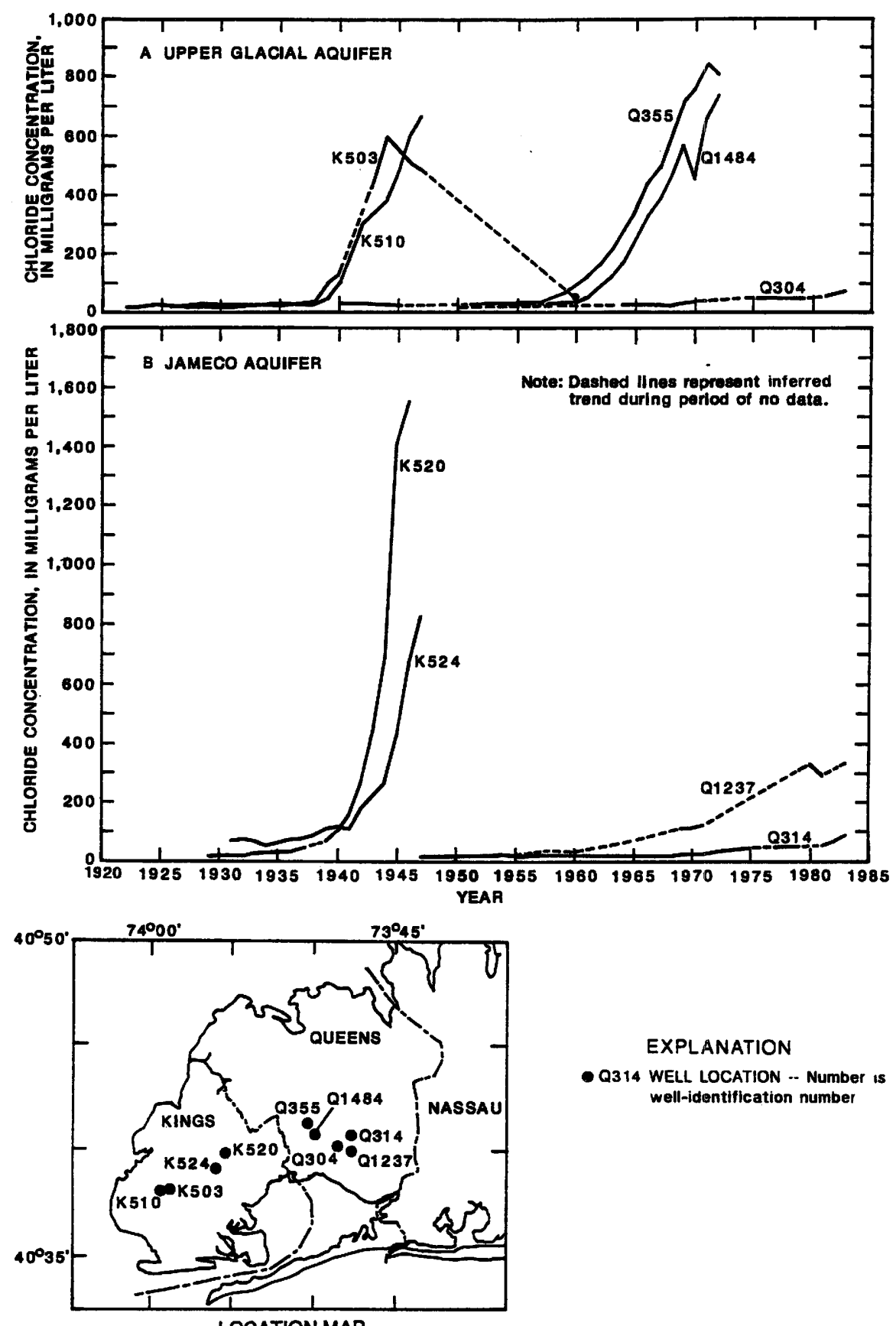

EXPLANATION

- Q314 WELL LOCATION -. Number is well-identification number

Figure 8. Chloride concentration in water from selected wells in Kings and Queens Counties: (A) Wells screened in the upper glacial aquifer. (B) Wells screened in the Jameco aquifer. (Data from U.S. Geological Survey files, Lusczynski, 1952, and selected annual reports of the Bureau of Water Supply, City of New York.) 
When the chloride concentration of water from the upper glacial aquifer began to increase, pumping was shifted eastward and to deeper aquifers, but a similar increase in chloride concentration in the deeper aquifers soon followed (fig. 8B). The transient response of water levels in the confined aquifers to pumping is quicker than that in the water-table aquifer, that is, changes in hydraulic head are transmitted more rapidly, and saltwater intrusion follows. Lusczynski (1952, p. 5-6) indicates that, during the 1930's and 1940's saltwater intrusion into the Jameco aquifer was more rapid than in the upper glacial aquifer and extended farther inland and caused higher chloride concentrations. The rise in chloride concentration at two wells screened in the Jameco aquifer is more rapid than at corresponding wells screened in the upper glacial aquifer. (Compare figs. 8A and 8B.)

The Lloyd aquifer shows no evidence of saltwater intrusion, most likely because it is tapped by only a few wells. Pumpage from the Lloyd in Kings County began in 1920 and, until 1940, averaged less than $1 \mathrm{Mgal} / \mathrm{d}$ (fig. 5). Well K464, on the western shore of Jamaica Bay and screened in the Lloyd aquifer (pl. 1), had chloride concentrations of 6 to $10 \mathrm{mg} / \mathrm{L}$ during 1937-50. High chloride concentrations were measured in water from this well in 1950, but because this was immediately after repair work had been done on these wells, it is probably a result of a damaged well casing that allowed shallow saline ground water to contaminate the well.

The maximum recommended concentration of chloride in community water systems is $250 \mathrm{mg} / \mathrm{L}$ (New York State Department of Health, 1977)the approximate taste threshold for most people. By 1940, public-supply water in Kings County had begun to exceed this amount, and, by 1947, chloride contamination in the upper glacial aquifer was widespread (fig. 9A). Although background chloride concentrations are probably $10 \mathrm{mg} / \mathrm{L}$ or less (see previous section), much of the shallow ground water in Kings County had been affected to some degree by chloride contamination from land surface (fig. 9A). Therefore, $40 \mathrm{mg} / \mathrm{L}$ has been used as a background level for chloride in shallow ground water (Soren, 1971).

Chloride concentrations at wells near the shore had reached 1,000 to $8,000 \mathrm{mg} / \mathrm{L}$ by 1947 , and the concentrations inland were as high as $700 \mathrm{mg} / \mathrm{L}$.
At the same time, chloride concentrations in the Jameco aquifer in Kings County were as high as $1,500 \mathrm{mg} / \mathrm{L}$. Queens County in 1947 had only traces of chloride in the upper glacial aquifer, however (figs. 8A and 9A).

Pumping in Queens County increased sharply in the early 1950's (figs. 4 and 5) and was accompanied by an increase in chloride concentrations. Water from two wells that tap the upper glacial aquifer in the Woodhaven franchise area (fig. 8A) showed a marked increase in chloride concentration from the late 1950's until 1974, when pumping for public supply (which was entirely from the upper glacial aquifer) in that area was stopped.

The map in figure 9B indicates that, in 1960, water from much of the upper glacial aquifer in western Queens County had chloride concentrations greater than $40 \mathrm{mg} / \mathrm{L}$. Chloride contamination appears to be greatest in shore areas and in the cone of depression around pumping centers in the Woodhaven franchise area (fig. 6D) and is largely the result of saltwater intrusion.

Some of the chloride contamination in Queens County is undoubtedly derived from inland surface sources, especially in northwestem Queens, which has been extensively developed since the 19th century and where water-table gradients indicate that saltwater intrusion is unlikely.

Chloride concentrations in Kings County in 1960 (fig. 9B) appear to show a decrease since the cessation of pumping in 1947 through dilution and the gradual recovery of ground-water levels (fig. 6). Water at well K503 in 1960 (fig. 8A) shows a considerable decrease in chloride concentration since 1947.

By 1970 , chloride contamination in the Woodhaven franchise area had become even more extensive (figs. 6 and 9C), and, by 1974, pumping for public supply had been stopped because of saltwater intrusion. Chloride contamination in the Jamaica area in 1970 was still virtually negligible (fig. 9C).

Wells in the Jamaica Water Supply Company area (southeastern Queens County)-Q304 in the upper glacial aquifer and Q1237 and Q314 in the Jameco aquifer (fig. 8)-all show a steady increase in chloride concentration since the 1960's. This could be a forewaming of sharp increases similar to those that occurred in western Queens in the 1960's and in Kings in the 1940's. 


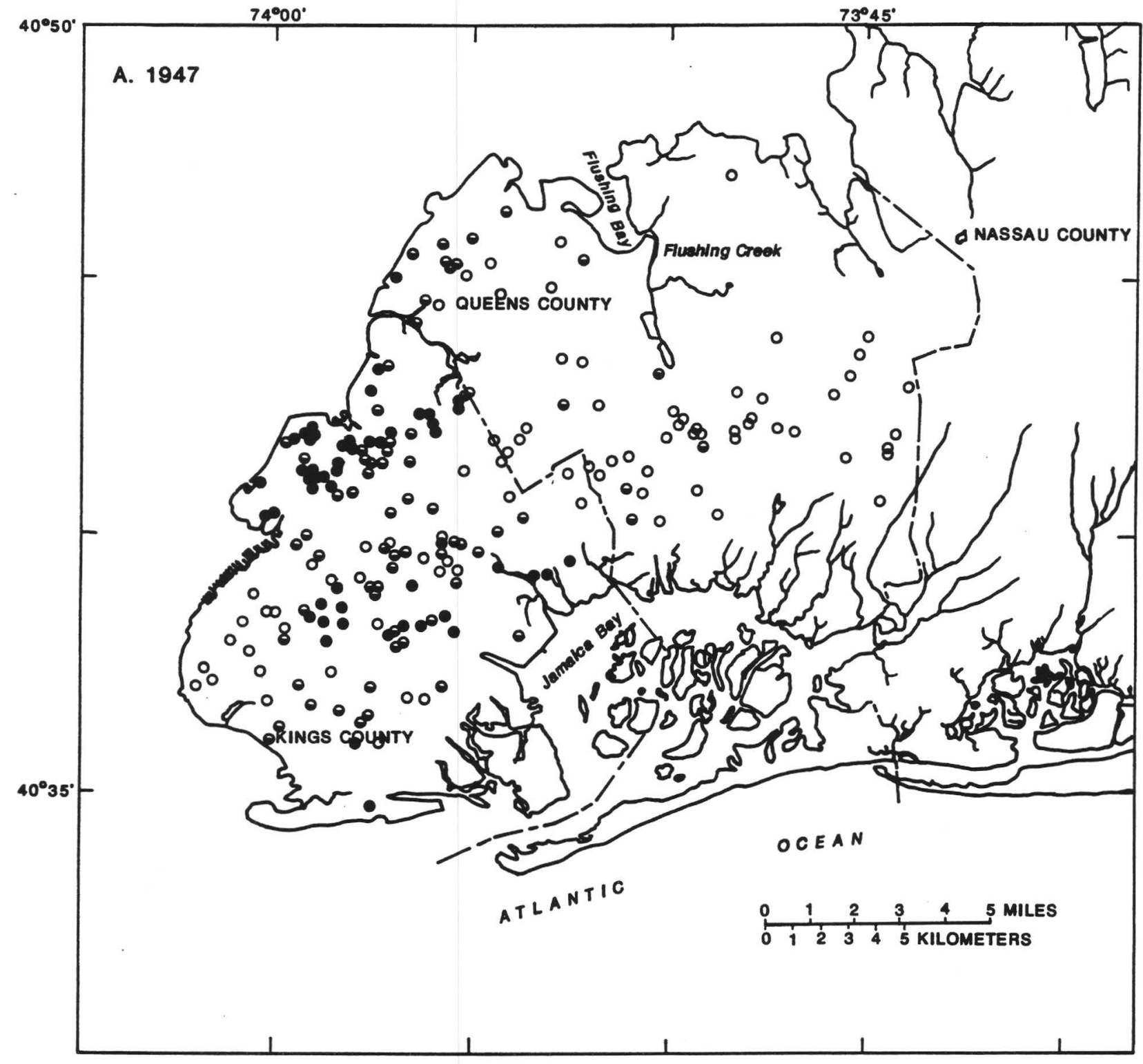

EXPLANATION

CHLORIDE CONCENTRATION,

IN MILLIGRAMS PER LITTER

- LESS THAN 40

- 40 TO 250

- MORE THAN 250

Figure 9A. Chloride concentrations in the upper glacial aquifer in Kings and Queens Counties in 1947. (Data from U.S. Geological Survey files, Lusczynski, 1952, and selected annual reports of the Bureau of Water Supply, New York City, 1948, 1962, and 1971.) 


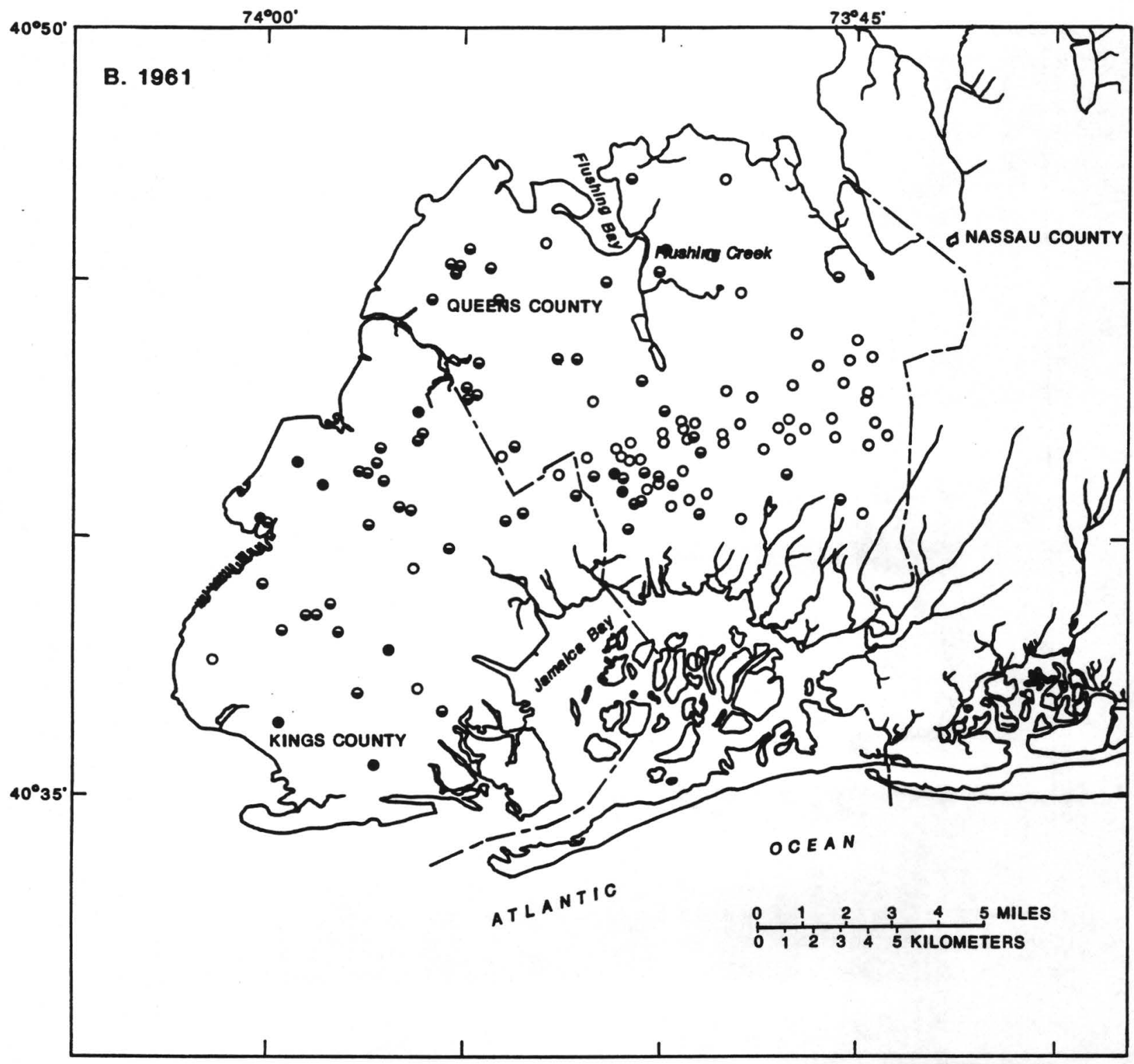

\section{EXPLANATION}

CHLORIDE CONCENTRATION,

IN MILLIGRAMS PER LITTER

O LESS THAN 40

- 40 TO 250

- MORE thAN 250

Figure 9B. Chloride concentrations in the upper glacial aquifer in Kings and Queens Counties in 1961. (Data from U.S. Geological Survey files, Lusczynski, 1952, and selected annual reports of the Bureau of Water Supply, New York City, 1948, 1962, and 1971.) 


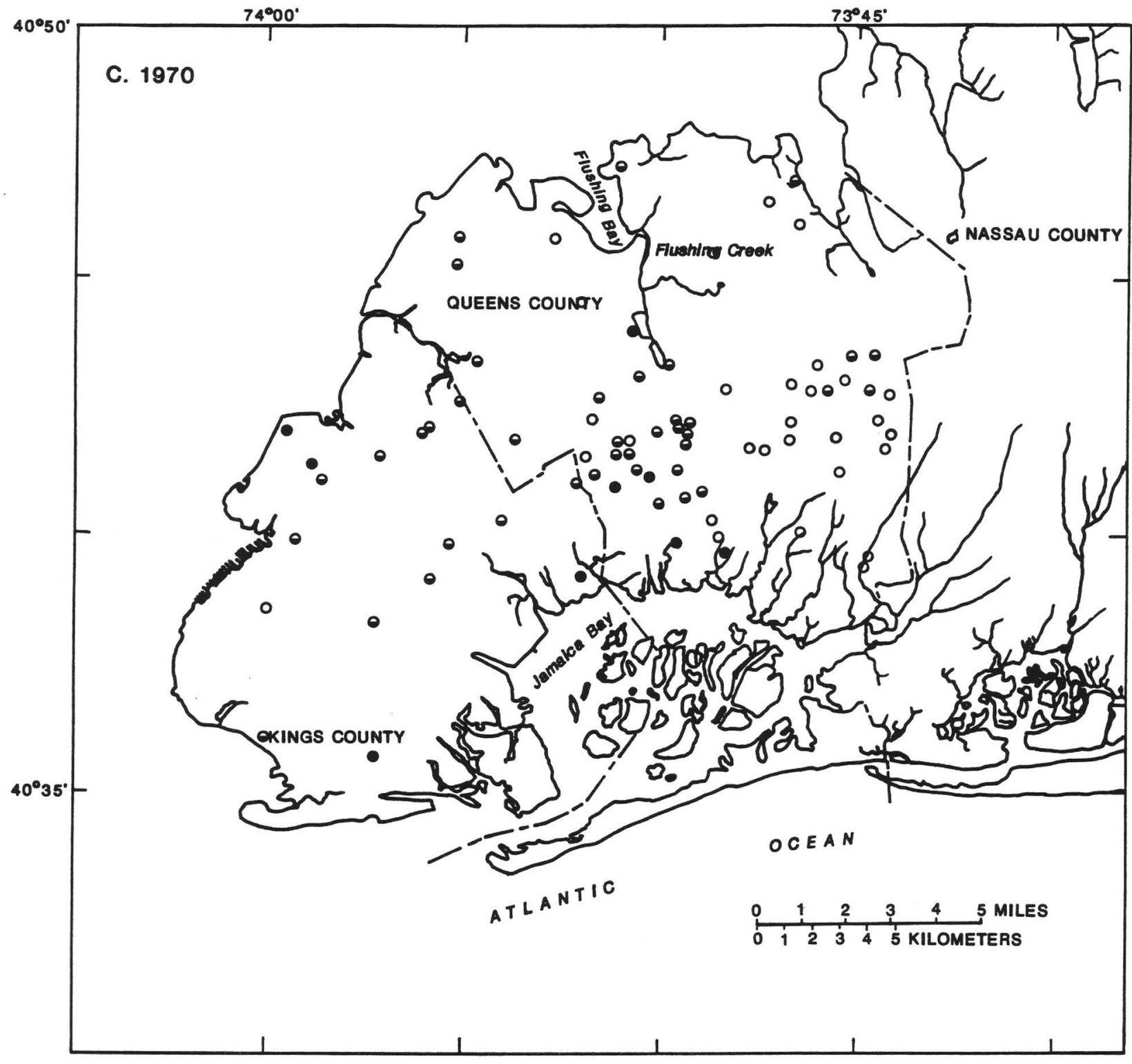

EXPLANATION

CHLORIDE CONCENTRATION

IN MILLIGRAMS PER LITTER

- LESS THAN 40

- 40 TO 250

- MORE THAN 250

Figure 9C. Chloride concentrations in the upper glacial aquifer in Kings and Queens Counties in 1970. (Data from U.S. Geological Survey files, Lusczynski, 1952, and selected annual reports of the Bureau of Water Supply, New York City, 1948, 1962, and 1971.) 


\section{Nitrate}

Nitrate is the predominant form of nitrogen found in ground water. After introduction at the water table, it has been found to be a persistent indication of contamination from land surface. The first introduction of nitrate to ground water resulted from domestic waste disposal and agricultural sources, which became widespread about 200 years ago. Other sources of nitrate are leaking sewer lines and leachate from landfills. Because elevated nitrate concentrations in water can be harmful, a limit of $10 \mathrm{mg} / \mathrm{L}$ nitrate (as nitrogen) is defined as drinking-water standard (New York State Department of Health, 1977). Data on nitrate concentrations in the upper glacial aquifer in Kings County during 1897-1916 (Kimmel, 1972) indicate that ground water in developed areas was already contaminated by the turn of this century. Nitrate concentrations (as nitrogen) in 13 of 14 wells in Kings sampled in 1942 ranged from 6 to $25 \mathrm{mg} / \mathrm{L}$ (Kimmel, 1972); the concentration in the remaining well was $2 \mathrm{mg} / \mathrm{L}$.

Data on nitrate contamination of the deeper aquifers in Kings County are scant. The amount of denitrification in deeper aquifers is undetermined, however, elevated concentrations in deep aquifers as early as 1929 indicate some downward migration of nitrate from the water-table aquifer (Kimmel, 1972, p. D202).

Veatch and others (1906) state that 8 of 13 private wells or pumping stations in Queens County sampled before 1903 had nitrate concentrations greater than $1 \mathrm{mg} / \mathrm{L}$ as $\mathrm{N}$ and as high as $34 \mathrm{mg} / \mathrm{L}$. Additional data on nitrate in Queens County are summarized in Soren (1971, table 1), which includes analyses of water from 38 wells (10 in the Lloyd aquifer, 15 in the Jameco-Magothy aquifer, and 13 in the upper glacial aquifer) that were sampled during the 1950's and 1960's. Nitrate (as N) concentrations were above $10 \mathrm{mg} / \mathrm{L}$ in water from only four of the wells, but many samples, including several from the Magothy aquifer, had concentrations higher than $0.2 \mathrm{mg} / \mathrm{L}$ (predevelopment level), which indicates some contamination in the upper glacial aquifer and local downward movement to the deeper aquifers. These data indicate that nitrate contamination in Queens County is not as advanced as Kings County.

\section{RECENT (1983) HYDROLOGIC CONDITIONS}

Hydrologic data collected in 1983 indicate that the ground-water reservoir in eastern Queens County is still severely stressed. The following paragraphs refer to maps and hydrogeologic sections that: (1) represent the current three-dimensional distribution of hydraulic head (2) indicate the patterns of ground-water movement, (3) define the distribution of ground-water quality on western Long Island, and (4) quantify the effects of the stresses of urbanization on the ground-watersystem budget.

\section{Water-Table and Potentiometric- Surface Altitudes}

Routine water-level measurements made by USGS throughout Long Island are used to monitor changes in the ground-water reservoir that result from natural hydrologic fluctuations or continued development by man. Water-level measurements in 194 wells in Kings, Queens, and western Nassau
County from January through April 1983 were used to construct a set of maps showing the configuration of the water table and the potentiometric surfaces in the confined aquifers of western Long Island (pl. 4, 5, and 6). Table 8 (at end of report) lists all observation wells, their location by latitude-longitude, and their screened interval.

Measurements were made in all available observation wells and industrial or public-supply wells that were not pumped during or immediately before the measurement period. The distribution of these wells is summarized by aquifer and county in table 4. The deeper aquifers have fewer wells, especially in Kings County, primarily because installation expenses are greater, and many wells in Kings County, abandoned since the 1940's or earlier, have been destroyed.

Plates 4, 5, and 6 show the distribution of hydraulic head in the upper glacial (water table) aquifer, the Jameco-Magothy aquifer, and the Lloyd aquifer, respectively. As described previ- 
ously, the Jameco and Magothy aquifers are presented as one hydrogeologic unit.

Construction of these maps entailed overlaying maps of successive aquifers to verify that vertical gradients consistently represented the three-dimensional pattern of ground-water flow. Hydrologic sections presented on plate 7 show the vertical distribution of head throughout the entire thickness of unconsolidated deposits. Together, the sections and maps give an indication of the threedimensional distribution of hydraulic head throughout the ground-water system and the pattern of ground-water flow. Most vertical gradients occur within confining units (except in the water-table aquifer near streams), enabling a set of maps and sections to be used effectively to represent three-dimensional flow patterns.

Additional information on hydrologic factors that affect the distribution of hydraulic head and movement of ground water within the system can be useful in constructing such maps. The location and average pumping rate during the measurement period of 103 industrial and public-supply wells are shown on plates 5 and 6; plate 7 shows the screened interval of each well on a cross section. These data help define the configuration of the cones of depression that are centered at the screens of the pumping wells. Other hydrogeologic characteristics that affect the head distribution and are shown on these maps include: (1) hydrogeologicunit geometry, particularly the extent of confining layers, which affect vertical head relations and pat- terns of flow between aquifers; (2) locations of permeability boundaries, that is, the boundary between zones that differ considerably in hydraulic conductivity; and (3) natural hydrologic boundaries such as gaining-stream channels and the saltwater-freshwater interface in the confined aquifers.

\section{Water-Table Configuration}

The configuration of the water table in westem Long Island, shown on plate 4, was constructed from water levels measured in 132 observation wells screened in the upper glacial aquifer (table 4) in March and April 1983. The water table shows anomalous mounds along the north shore. The water level in well Q2791 in northeastern Queens was more than $50 \mathrm{ft}$ above sea level and has been comparably high in recent years. These features are not perched ground water because they are hydraulically connected with the water table, as indicated by the fact that well Q2791 is screened from 11 to $19 \mathrm{ft}$ above sea level. Rather, this mounding is attributed to two causes. The first is that the upper glacial material on the north half of Long Island consists of moraine deposits that, on the average, have a hydraulic conductivity 2 to 10 times lower than the outwash deposits on the south shore and locally could be several orders of magnitude lower. This contrast in hydraulic conductivity is a major reason for the north-to-south asymmetry of the water table throughout Long Island. The water-table divide is much closer to the northern

Table 4.-Number of observation wells in which water levels were measured, January through April 1983.

\begin{tabular}{|c|c|c|c|c|c|}
\hline \multirow[b]{2}{*}{ County } & \multicolumn{5}{|c|}{ Aquifer } \\
\hline & Upper glacial & Jameco $^{1}$ & Magothy' & Lloyd & Total \\
\hline Kings & 31 & 2 & 0 & 1 & 34 \\
\hline Queens & 48 & 5 & 13 & 11 & 77 \\
\hline Nassau $^{2}$ & 53 & 1 & $\underline{21}$ & 8 & 83 \\
\hline Total & 132 & 8 & 34 & 20 & 194 \\
\hline
\end{tabular}


shore than the southern shore throughout Kings and Queens Counties.

The second reason for the anomalous high ground-water levels along the north shore is the configuration of the base of the water-table aquifer. This aquifer is underlain by either bedrock or confining-unit material overlying bedrock, either of which forms a virtually impermeable bottom boundary to the aquifer at a shallow depth (fig. 10). The Raritan confining unit is above sea level in northeast Queens, and bedrock crops out in northwest Queens (fig. 10 and sections B-B' and D-D' on pl. 7), which further restricts ground-water discharge to the north shore and results in the steep northward gradients (pl. 4).

Locations of 38 wells pumped for either industrial supply or public supply are shown on plate 4 . Two major cones of depression caused primarily by pumping (during the measurement period) of 13.8 Mgal/d for public supply are evident in southem Queens County, where water levels have been drawn down to below sea level. A considerable increase in gradients from Nassau into Queens County since the predevelopment period indicates that the amount of ground water flowing across the county line has increased significantly. The westem (smaller) cone of depression has no discharging wells at its center in the upper glacial aquifer. Comparison of the water-table map with the potentiometric-surface map of the Jameco-Magothy aquifer (pl. 5) indicates, however, that the larger cone of depression in the water table is caused by pumping in the Jameco-Magothy aquifer. This occurs in an area where the Gardiners Clay is absent and the aquifers have substantial hydraulic connection.

\section{Potentiometric Surface of the Jameco- Magothy Aquifer}

The potentiometric-surface altitude in the Jameco-Magothy aquifer is shown on plate 5. Water levels measured in $\mathbf{4 2}$ wells screened in this aquifer in March and April 1983 were used to construct the map. The number of available observation wells decreases westward rapidly in the area; only two are available in Kings County (table 4). Plate 5 also shows the northern extent of

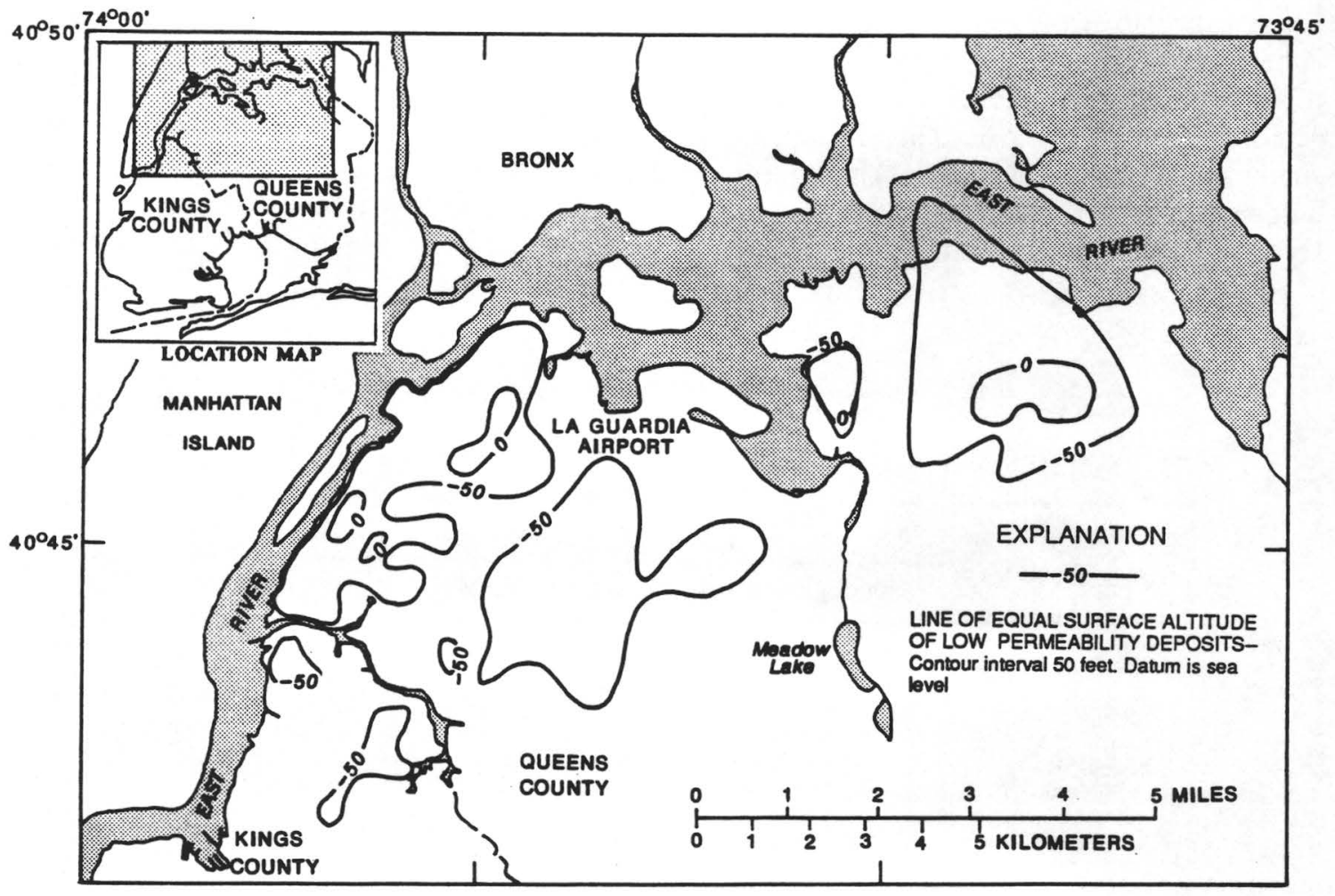

Figure 10. Upper surface altitude of deposits with low permeability at base of water-table aquifer in northern Kings and Queens Counties. 
this aquifer unit and the Gardiners Clay. (The Gardiners Clay, where present, separates the JamecoMagothy aquifer from the overlying upper glacial aquifer.) The Gardiners Clay overlaps the JamecoMagothy aquifer throughout Kings County; thus, all ground water that moves vertically between the Jameco-Magothy and upper glacial aquifers must move through the confining unit. In Queens County, the aquifer extends farther north, and the confining unit recedes southward. In areas where the aquifer is not overlain by the Gardiners Clay, the Jameco-Magothy aquifer is in direct contact with the upper glacial aquifer.

Careful consideration was given to the extent of the confining unit in plotting the head relations between the Jameco-Magothy and upper glacial aquifers. Vertical head differences between the aquifers are greater, and flow rates lower, where the confining unit is present. The resulting distribution of head in both aquifers (pls. 4,5 ) indicates vertical gradients consistent with the three-dimensional patterns of ground-water flow. For example, ground-water gradients are downward beneath the water-table mound in northeast Queens County, but to the east, under Alley Pond Creek, seepage to the creek results in upward gradients.

Head distribution in the Jameco-Magothy in Kings County indicates that water enters the aquifer vertically from the upper glacial aquifer by downward seepage through the Gardiners Clay and then flows southward to near the shore, where it discharges by upward seepage back through the Gardiners Clay.

Ground-water flow patterns in Queens County are more complex than in Kings County. A deep erosional channel through the Cretaceous deposits trends north-south through Queens County. (The origin of this channel is discussed in a previous section; a map of the configuration of the Cretaceous surface is shown in Smolensky and others, 1989). This channel also cuts through the Raritan confining unit and was subsequently filled with upper glacial deposits, which act as a conduit for ground-water fiow between all aquifer units (sections $\mathrm{C}-\mathrm{C}^{\prime}$ and $\mathrm{E}-\mathrm{E}$ ', pl. 7). The area in which these glacial deposits are laterally contiguous with the Jameco-Magothy aquifer is shaded on plate 7 to identify this pathway for ground-water flow; this is a significant factor in the three-dimensional pattern of ground-water movement in this area. The
Jameco-Magothy aquifer is underlain everywhere by the Raritan confining unit except in this eroded channel.

Well Q2410 taps the eroded channel in northcentral Queens; it is screened in upper glacial deposits but at a depth equivalent to the JamecoMagothy aquifer. The hydraulic head in this well is similar to that in the overlying glacial deposits, which is consistent with the contention that the channel acts as a direct pathway for water from the upper glacial aquifer to pumping wells in the Jameco-Magothy aquifer.

Pumping for public supply in the JamecoMagothy aquifer in Queens County during the measurement period was $31.26 \mathrm{Mgal} / \mathrm{d}$; most pumping wells are in the east-central part of the county, and ground-water levels have been drawn down below sea level in an extensive cone of depression. The Gardiners Clay is absent throughout most of this area, and the effects of pumping have propagated into the water-table aquifer (pl. 4). A concentration of pumping in southwestern Nassau County has drawn ground-water levels down to below sea level in that area.

An important lateral hydrologic boundary in the Jameco-Magothy aquifer is the interface between fresh and saline ground water. This interface is actually a zone of diffusion in which chloride concentrations increase from the typical concentration in the fresh ground-water system (less than $40 \mathrm{mg} / \mathrm{L}$ ) to that of seawater, about $19,000 \mathrm{mg} / \mathrm{L}$. Under undisturbed conditions, this zone of diffusion probably does not exceed several hundred feet in width, but nearby pumping can cause considerable mixing and expansion of this zone. Chloride concentrations in water samples from wells near the shore were used as a guide to estimate the approximate position of the interface; results are discussed in greater detail in the section "Saltwater Intrusion" (p. 42).

The configuration of the saltwater-freshwater interface is controlled by the distribution of head within the ground-water system and tends toward an equilibrium state in which the pressures in saltwater and freshwater balance. The interface typically extends farther landward with increasing depth (pl. 7). The interface in southern Kings and Queens extends several miles inland in the JamecoMagothy aquifer. Two holes in the Gardiners Clay along the south shore (pl. 5) probably partly explain 
the extreme landward position of the interface in this part of the Jameco-Magothy aquifer. Before development, these holes permitted discharge upward, lowering head in the Jameco-Magothy aquifer, during pumping, they provide a pathway for intrusion downward into the aquifer.

The altitude of the base of the JamecoMagothy aquifer at the edge of the interface ranges from 300 to $600 \mathrm{ft}$ below sea level across southwestern Long Island. Freshwater heads of 7.5 to $15 \mathrm{ft}$ are required to balance static saline ground water at these depths. Hydraulic heads along the edge of the freshwater system range from 1 to $5 \mathrm{ft}$ (pl. 5), indicating that the interface is not in an equilibrium position and is moving landward.

Water levels at several wells in southwestern Nassau County have been below sea level (fig. 11) and are depicted as a separate cone of depression in several published potentiometric-surface maps of the Magothy aquifer. This area has no known stress that could cause such a local cone of depression, however. An inspection of recent waterquality analyses shows that the dissolved-solids concentrations at these wells are elevated by sea water and are high enough to significantly increase the density of water in the well. This would cause the measured hydraulic head to be lower than if freshwater were in the well casing. Thus, the observed depressions in this area do not indicate converging flow patterns, but are rather an artifact of pressure-head measurement in terms of a fluid that is denser than freshwater.

Evaluation of horizontal gradients and flow rates in a system of dilute seawater such as this require adjustment of head measurements to the calculated head of a common fluid (freshwater). These head data are referred to as freshwater or equivalent-freshwater head. The equation for freshwater head $\left(h_{f}\right)$ is given as:

$$
h_{f}=\left(h_{s}-z\right) \frac{\rho_{s}}{\rho_{f}}+z
$$

where: $h_{s}$ is measured head of saline ground water,

$\rho_{s}$ is density of saline ground water, $\rho_{f}$ is density of fresh ground water, and $z$ is altitude of the well screen.
The density of the water in the casing (the measurment fluid) was estimated assuming a proportional mixture of freshwater and seawater determined by the measured chloride concentration. The chloride concentration, estimated density, and freshwater and saltwater heads, in pertinent wells are presented in table 5. Corrections to freshwater head resulted in changes of as much as $12 \mathrm{ft}$ (well N6702). The distribution of head in wells in southern Queens and southwestern Nassau County, both as actually measured and as equivalent-freshwater head, is shown in figure 11. The measured heads in wells N3861, N6510, and N6702 were below sea level as a result of saline water in the well casings. The distribution of equivalent freshwater head does not show a cone of depression. Hydraulic gradients in freshwater head indicate a landward movement of ground water toward pumping centers to the north.

Ground-water levels shown on plates 4, 5, and 6 were made as part of an islandwide synoptic measurement; water samples were not collected at the time of measurement. Estimates of fluid density were made from chloride concentrations in the most recent sampling of these wells; the dates of these analyses are included in table 5. A more accurate estimate of the effects of local differences in fluid density would be possible if sampling and chemical analyses were included with future water-level measurements. Thus, if a well is expected to be affected by saltwater, it would first be pumped to ensure that the water in the casing is indicative of the local ground water; then a sample would be taken for chemical analysis, and finally the recorded static water level would be measured.

The rate of movement of the saltwater-freshwater interface is difficult to estimate. To obtain an approximation, Darcy's law was applied along a transect trending from the center of Jamaica Bay north-northeastward toward the center of pumping. Estimates of the horizontal component of velocity based on published values of water-transmitting coefficients ranged from 0.5 to $1.0 \mathrm{ft} / \mathrm{d}$. Although this rate may seem slow, at a rate of $1.0 \mathrm{ft} / \mathrm{d}$, the interface would advance $1 \mathrm{mi}$ in 15 years, a distance of major consequence to long-range resource management, especially because intrusion could be more rapid near well screens or in local zones with high permeability or low porosity. 

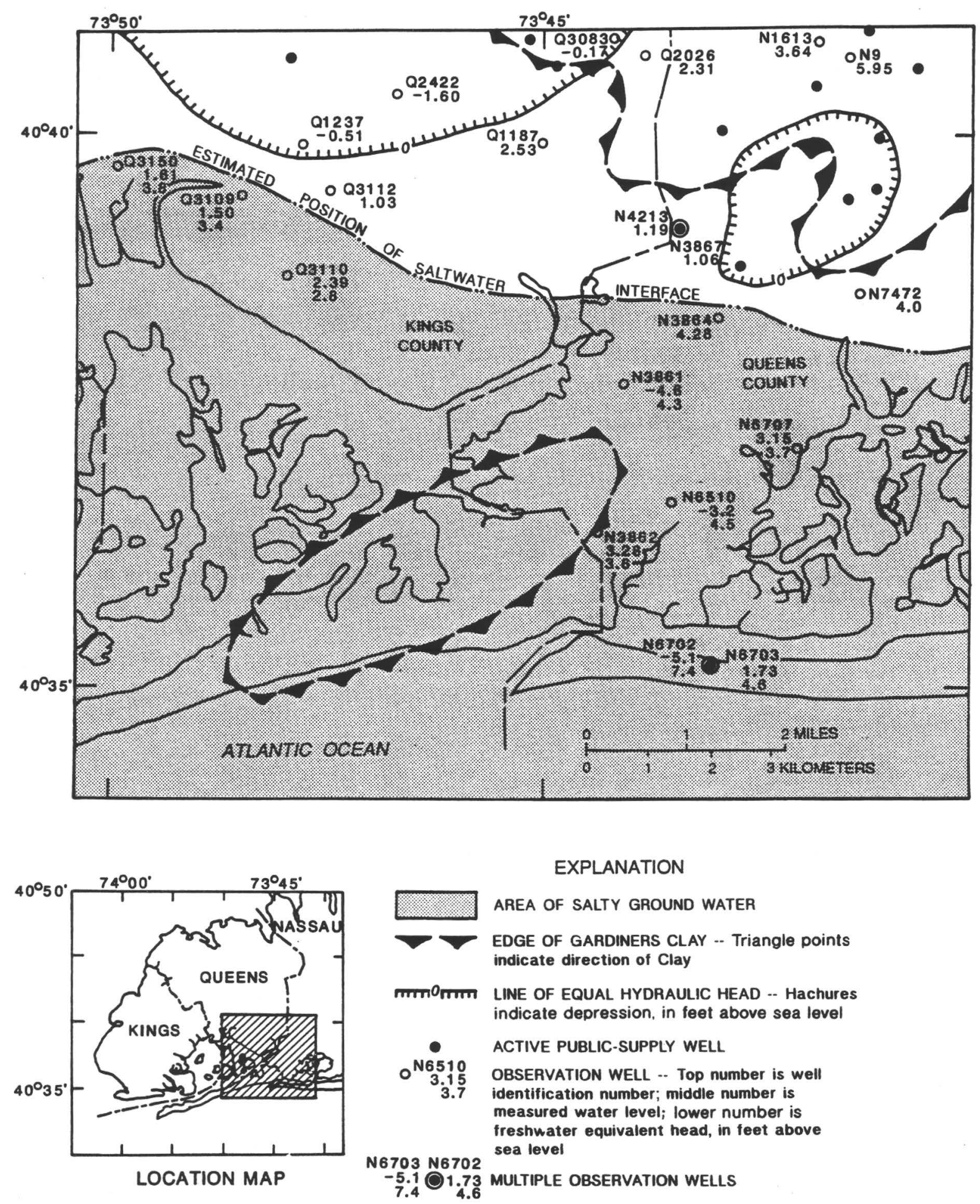

Figure 11. Distribution of hydraulic head in southern Queens and southwestern Nassau County, as measured and converted to freshwater equivalent head. 
Table 5. - Equivalent freshwater head at wells affected by saline water in the Janeco-Magothy aquifer.

[Well locations are shown in fig. 11.]

\begin{tabular}{ccccccc}
\hline Well no. & $\begin{array}{c}\text { Date of } \\
\text { sample } \\
\text { collection }\end{array}$ & $\begin{array}{c}\text { Average } \\
\text { screen } \\
\text { altitude } \\
\text { (feet below } \\
\text { sea level) }\end{array}$ & $\begin{array}{c}\text { Chloride } \\
\text { concentration } \\
\text { (milligrams } \\
\text { per liter) }\end{array}$ & $\begin{array}{c}\text { Density } \\
\text { (grams per } \\
\text { cubic centi- } \\
\text { meter) }\end{array}$ & $\begin{array}{c}\text { Saltwaterhead } \\
\text { (feet above or } \\
\text { below (-) } \\
\text { sea level) }\end{array}$ & $\begin{array}{c}\text { Freshwater } \\
\text { head } \\
\text { (feetabove sea } \\
\text { level) }\end{array}$ \\
\hline N6703 & $10 / 5 / 83$ & -460 & 5,800 & 1.0061 & 1.7 & 4.6 \\
N6702 & $8 / 6 / 81$ & -672 & 15,000 & 1.0187 & -5.1 & 7.4 \\
N6510 & $4 / 10 / 62$ & -447 & 14,000 & 1.0173 & -3.2 & 4.5 \\
N3861 & $9 / 1 / 81$ & -517 & 14,000 & 1.0173 & -4.6 & 4.3 \\
N6707 & $9 / 28 / 83$ & -492 & 1,900 & 1.0010 & 3.2 & 3.7 \\
N3862 & $8 / 26 / 81$ & -294 & 1,900 & 1.0010 & 3.3 & 3.6 \\
Q3110 & $7 / 18 / 83$ & -306 & 2,300 & 1.0014 & 2.4 & 2.8 \\
Q3109 & $8 / 18 / 83$ & -278 & 6,400 & 1.0069 & 1.5 & 3.4 \\
Q3150 & $6 / 21 / 83$ & -119 & 15,000 & 1.0187 & 1.6 & 3.8 \\
\hline
\end{tabular}

1 Estimated from a relation between chloride concentration and density in dilute seawater solutions (Weast, 1981, p. D229).

\section{Potentiometric Surface of the Lloyd Aquifer}

The potentiometric-surface altitude of the Lloyd aquifer measured in January 1983 is shown on plate 6. Only 20 wells that tap the Lloyd aquifer were available for measurement, and only one is in Kings County. The Raritan confining unit overlaps the Lloyd aquifer throughout Kings and westem Queens. In central Queens, where the ancestral Hudson River channel eroded the Raritan confining unit away (shaded on pl. 6), upper glacial sediments lie either directly on bedrock or on deposits of the Lloyd aquifer and thus afford a direct pathway for ground-water exchange among all three aquifers.

The potentiometric-surface map (pl. 6) shows four public-supply wells, all in Queens County, that tap the Lloyd aquifer. Together they pumped at a rate of $5.94 \mathrm{Mgal} / \mathrm{d}$ during the measurement period. The cone of depression created by these wells is deeper and more extensive than that in the overiying Jameco-Magothy aquifer (pl. 5), where pumping is more than six times greater. No observation wells are near the center of the cone of depression; thus, the shape of the potentiometric surface near these wells is only estimated. Water levels measured in the pumping wells after they had been temporarily shut down for several hours were still more than $20 \mathrm{ft}$ below sea level. Although these data are difficult to interpret and are not used to indicate absolute head values, they are considered to indicate the maximum groundwater level in an area immediately surrounding the pumping wells during their operation.

The configuration of the potentiometric surface near the eroded channel indicates that water flows downward through the channel-fill deposits from the overlying aquifers to recharge the Lloyd aquifer. Head contours in the Lloyd aquifer indicate that water is diverging from this source area.

The Lloyd aquifer is expected to be more sensitive to pumping than the overlying aquifers for two reasons. First, probably only about 5 percent of the total volume of water in the system moves through the Lloyd because it is the deepest aquifer and is almost everywhere separated from the rest of the system by the Raritan confining unit. Second, even though pumping in the Lloyd aquifer would increase the downward hydraulic gradients 
between the overlying Jameco-Magothy aquifer and the Lloyd aquifer and would increase the downward flow of water into the Lloyd, the considerable pumping in the overlying aquifer has caused a significant drawdown in that aquifer, thus, even a small amount of pumping from the Lloyd would lower the hydraulic head to below that in the overlying aquifer. The result is that any pumping causes a more extensive and deeper cone of depression in the Lloyd aquifer than in the overlying aquifer, as seen through comparison of plates 5 and 6.

Pumping for public supply from the Lloyd aquifer occurs at two locations in Nassau County, near the Queens County line. One is near the north shore, where the Lloyd aquifer is fairly close to land surface; the other is at Long Beach on the south-shore barrier island, where it is the only source of fresh ground water.

The saltwater-freshwater interface in the Lloyd aquifer is estimated to lie just off the south shore (pl. 6). Here the base of the Lloyd ranges from 600 to $1,200 \mathrm{ft}$ below sea level. Freshwater heads of 15 to $30 \mathrm{ft}$ would be needed to balance static seawater at these depths, but water-level measurements along the interface indicate that head in the Lloyd aquifer does not exceed a few feet. Thus, data indicate that, as in the overlying Jameco-Magothy aquifer, the interface is not in an equilibrium position and is moving landward.

Darcy's Law was used to estimate the rate of landward movement on a transect due north through the center of Jamaica Bay (pl. 6). Estimates of the horizontal velocity are from 0.02 to $0.05 \mathrm{ft} / \mathrm{d}$-much lower than in the overlying Jameco-Magothy aquifer and consistent with the smaller ground-water gradients observed in the Lloyd (pl. 5, 6).

\section{Distribution of Hydraulic Head Along Selected Vertical Sections}

The five hydrogeologic sections shown on plate 7 depict the vertical variations in hydraulic head within the system. All pumping wells and observation wells that lie along or close to the sections are indicated with their screened intervals; the observed head values shown are considered the average head over the screened interval. Equipotential lines are near vertical in each aquifer unit, where ground-water gradients are generally horizontal, but refract toward the horizontal where they enter the confining units because here, the vertical gradients are much larger than in the aquifers.

In the interpretation of head maps (plan view), ground-water flow paths are assumed to be aligned with the direction of the steepest hydraulic gradient. In the interpretation of hydrologic sections, however, this is not always true. In vertical sections, flowlines generally are not perpendicular to equipotential lines because the aquifer units are anisotropic, and the section is drawn with extreme vertical exaggeration.

The estimated configuration of the saltwaterfreshwater interface is also indicated; it typically extends landward with depth and is near vertical within confining layers. It could contain more irregularities than are shown as a result of extensive clay lenses within the aquifer units or local drawdown from pumping.

Section A-A' (pl. 7) trends north-south in Kings County. The water table along this profile is asymmetric because the ground-water divide is close to the north shore. The water-table mound at the divide is probably caused by a local zone of low permeability in the moraine deposits. Low head in the Jameco-Magothy aquifer, caused by pumping in Queens County, has caused the saltwater-freshwater interface in this aquifer to move inland. As a result, subsea discharge upward through the Gardiners Clay has probably ceased.

Freshwater in the Lloyd aquifer extends considerably farther seaward than in the JamecoMagothy, but, as stated previously, head in the freshwater system is inadequate to balance sea water at the depths of the Lloyd aquifer. Thus, saline ground water in the Lloyd probably is moving slowly landward.

Section B-B' (pl. 7) trends from northwestern Queens County southward to near the KingsQueens County line. The extreme thinning of the upper glacial aquifer at the north shore is evident in the section. Within the north-central part of the section is a large area in which the bedrock is overlain by confining-unit material; as a result, the bottom boundary of the aquifer system is less than $\mathbf{5 0}$ $\mathrm{ft}$ below sea level locally. This is considered a major cause of high ground-water levels along the north shore.

Freshwater in the Jameco-Magothy aquifer is limited along this section. The hole in the overlying Gardiners Clay, which is evident in this section, provides a pathway for intrusion of saline 
ground water. Ground water in the Lloyd aquifer at section B-B' flows generally eastward toward the major pumping center.

Section C-C' (pl. 7) trends southward from Flushing Bay and crosses the ancestral Hudson River channel, which has eroded through all Cretaceous deposits and forms a pathway for water to the Lloyd aquifer from above. Water at well Q2418 has attained a chloride concentration as high as $550 \mathrm{mg} / \mathrm{L}$ (1981), which may indicate that saltwater from Flushing Bay and its estuary was drawn into the ground-water system, possibly by intensive pumping during the 1960 World's Fair or from public-supply wells screened in the JamecoMagothy and Lloyd aquifers to the south. The latter possibility warrants concern for potential saltwater intrusion from the north shore toward the major pumping centers in central Queens.

Section D-D' (pl. 7) trends north-south near the Queens-Nassau County border. Only small traces of the Jameco Gravel have been found this far east. This section indicates that the high pumping rates in southeastem Queens County have caused landward gradients in the Lloyd and Jameco-Magothy aquifers. Flow in small zones along the north and south shores in the upper glacial aquifer is seaward, though.

Saline ground water probably is migrating downward into the Lloyd aquifer from the overlying Jameco-Magothy aquifers. Darcy's Law for fluids of variable density was used with data from wells N6703 and N8011 to estimate the vertical velocity and traveltime for saline ground water to cross the Raritan confining unit. Darcy's Law is given as:

$$
V_{z}=-\frac{k_{z}}{n \mu}\left(\frac{\Delta P}{\Delta Z}+\rho g\right)
$$

where: $V_{2}$ is vertical velocity component,

$\boldsymbol{k}_{\mathrm{z}}$ is vertical intrinsic permeability,

$n$ is porosity, is viscosity,

$P \quad$ is change in pressure across the confining unit,

$\rho$ is density, and

$Z \quad$ is thickness of confining unit, and

$g$ is the gravitational constant

Conservative values for aquifer properties were assumed, including $n=0.2$, and $k_{\mathrm{z}}$ is calculated from a vertical hydraulic conductivity of
$0.002 \mathrm{ft} / \mathrm{d}$ for freshwater. A density of $1.019 \mathrm{~g} / \mathrm{cm}^{3}$ was used for ground water overlying the Raritan confining unit. The resulting velocity was about $0.2 \mathrm{ft} / \mathrm{yr}$, and the traveltime across the confining unit was about 1,250 years. This indicates that lateral intrusion of saltwater within the Lloyd aquifer poses a greater threat than intrusion from the overlying aquifer.

Section E-E' (pl. 7) runs east-west through Kings and Queens Counties. This section shows the severe effects of pumping in Queens County. Large westward gradients indicate movement of ground water from Nassau County into Queens and downward into the Lloyd aquifer. The vertical pathway for water to the Lloyd aquifer through the ancestral Hudson River channel is also evident in this section. Sections D-D' and E-E' show a larger cone of depression in the Lloyd than in the overlying aquifers despite the lower pumpage.

\section{Water Budget}

Even though much of the ground-water system in Kings County is recovering from previous stress, and water levels now approach those of 1903, some severe, perhaps irreversible, deviations from the predevelopment flow patterns persist. Under predevelopment conditions, ground water was replenished entirely by recharge from precipitation and discharged solely by seepage to streams and as subsea outflow to the surrounding saltwater bodies. Urbanization and pumping have altered recharge and discharge patterns and introduced new components to the water budget. The estimated quantities of inflow and outflow in 1983 are compared with predevelopment values in table 6 . The water budget was developed through evaluation of hydrologic data and through calibration of a three-dimensional ground-water flow model of the Long Island ground-water system (H. T. Buxton and D. A. Smolensky, U.S. Geological Survey, written commun., 1988), which was being developed concurrently with this project.

$$
\text { Inflow }
$$

The large expanses of paved, impervious surfaces in Kings and Queens Counties have caused increased runoff and evaporation, which in turn have led to a major reduction in recharge from precipitation. Analysis of land use in Kings and Queens by the City of New York (New York City 
Department of Environmental Protection, 1979) indicates that Kings County has been the most severely affected by development and that Queens, although also affected, still has areas of permeable land surface such as parks, cemeteries, and lowdensity residential communities. About 15 percent of precipitation, $24 \mathrm{Mgal} / \mathrm{d}$ countywide or 0.32 (Mgal/d)/mi2 in Kings County, and about 35 percent of precipitation, $83 \mathrm{Mgal} / \mathrm{d}$ countywide or $0.73(\mathrm{Mgal} / \mathrm{d}) / \mathrm{mi}^{2}$ in Queens County, is estimated to enter the ground-water system as recharge, a considerable decrease from that which reached the aquifers before development, $1.1(\mathrm{Mgal} / \mathrm{d}) / \mathrm{mi}^{2}$ (table 6). Recharge in neighboring Nassau County continues to equal about 50 percent of precipitation, even under present urban conditions, because an extensive recharge-basin system captures runoff and returns it to the ground.

A large volume of water is returned or added to the ground-water system as leakage from artificial structures, which include water-supply lines and sewer lines, and as infiltration of water used for purposes such as lawn sprinkling. In areas where the water was pumped from the ground, such infiltration would constitute only a partial return to the system. In 1983, $57 \mathrm{Mgal} / \mathrm{d}$ of water was pumped from local aquifers to supply about 500,000 people and 7,600 commercial and industrial users in southeastern Queens. All of Kings County and most of Queens County are supplied with water totaling almost $700 \mathrm{Mgal} / \mathrm{d}$ from upstate surfacewater reservoirs, however (New York City Bureau of Water Supply, written commun., 1983). Infiltration of water leaking from this source constitutes artificial recharge from an external and potable source. In all, a total of about $760 \mathrm{Mgal} / \mathrm{d}$ (450 $\mathrm{Mgal} / \mathrm{d}$ in Kings and $310 \mathrm{Mgal} / \mathrm{d}$ in Queens) is transmitted through the water-supply system, which contains $4,270 \mathrm{mi}$ of supply lines $(1,900 \mathrm{mi}$ in Kings County and 2,370 mi in Queens) and has 613,000 service connections $(313,000$ in Kings County and 300,000 in Queens) (New York City Department of Environmental Protection, 1981, and Jamaica Water Supply Co., oral commun., 1984). Although many water-main breaks are tabulated annually by the New York City Bureau of Water Supply, constant leaking of the aging watersupply system is the largest source of recharge from artificial sources.

The total volume of leakage from artificial sources is difficult to estimate but undoubtedly constitutes a major part of the present groundwater budget. The total rate of infiltration from these sources is estimated to be about $70 \mathrm{Mgal} / \mathrm{d}$, although it could be larger. The distribution of this recharge corresponds to water-supply and sewer networks. About $30 \mathrm{Mgal} / \mathrm{d}$ is estimated to infiltrate in Kings and $40 \mathrm{Mgal} / \mathrm{d}$ in Queens.

Table 6. Water budgets for predevelopment and recent (1983) conditions.

[Values are in million gallons per day]

\begin{tabular}{lcc}
\hline \multicolumn{1}{c}{ Budget component } & $\begin{array}{c}\text { Predevelopment } \\
\text { (pre-1900) conditions }\end{array}$ & $\begin{array}{c}\text { Recent (1983) } \\
\text { conditions }\end{array}$ \\
\hline INFLOW & 209 & 107 \\
Recharge from precipitation & 0 & 70 \\
Leakage from water-supply lines and other infiltration & 6 & 2 \\
Ground-water inflow from Nassau & 215 & 186 \\
$\quad$ Total & & 11 \\
OUTFLOW & 62 & \\
Base flow to streams & & 57 \\
Pumpage & 0 & 17 \\
$\quad$ Public supply & 0 & 101 \\
$\quad$ Private (net) & 153 & 186 \\
Subsea discharge & 215 & \\
Total & & \\
\hline
\end{tabular}


The final component of inflow to westem Long Island is ground-water flow from Nassau County. Large hydraulic gradients in all aquifer units indicate that a significant amount of water enters from Queens County as subsurface flow. A flow-model analysis indicated that about $9 \mathrm{Mgal} / \mathrm{d}$ of ground water flows across the Nassau-Queens border, a 50-percent increase from pre-development conditions as a result of the steeper gradients induced by current pumping rates.

Total inflow to the western Long Island ground-water system from the above sources is $186 \mathrm{Mgal} / \mathrm{d}$. This is less than the total amount of water entering before development. Even the significant inflow from leakage of imported surface water is insufficient to compensate for the loss of natural recharge through urbanization.

\section{Outflow}

Water is discharged from the ground-water system in three ways - as stream base flow, through pumpage, and as subsea outflow. Under predevelopment conditions, base flow constituted a significant outflow from the ground-water system. Today, however, only two major streams remain in Kings and Queens (Flushing Creek and Alley Creek). These, along with several smaller creeks, receive a total of about $11 \mathrm{Mgal} / \mathrm{d}$ in ground-water seepage (base flow).

As stated earlier, ground water that is pumped and either lost by evaporation or discharged to the sea is considered consumptive (net) pumpage and represents a net draft on the ground-water system. In 1983, pumpage for public supply from Queens aquifers was $57 \mathrm{Mgal} / \mathrm{d}$. Of the $57 \mathrm{Mgal} / \mathrm{d}$ of public-supply pumpage in Queens County, 11.8 $\mathrm{Mgal} / \mathrm{d}$ was pumped from the upper glacial aquifer, $39.3 \mathrm{Mgal} / \mathrm{d}$ from the Jameco-Magothy aquifer (35 $\mathrm{Mgal} / \mathrm{d}$ from the Magothy aquifer and $4.3 \mathrm{Mgal} / \mathrm{d}$ from the Jameco aquifer), and $5.9 \mathrm{Mgal} / \mathrm{d}$ from the Lloyd aquifer (Jamaica Water Supply Company, written commun., 1984).

Private pumping includes pumping for industrial purposes and for dewatering in areas of ground-water flooding. The water pumped for these purposes is discharged to sewers with ocean outfall and is assumed consumptive. Net industrial pumpage in 1983 is estimated to have been 2.3 $\mathrm{Mgal} / \mathrm{d}$ in Queens and 6.6 Mgal/d in Kings (New York State Department of Environmental Conser- vation, written commun., 1984). In 1983, subway dewatering in the Flatbush area of Kings County averaged $4 \mathrm{Mgal} / \mathrm{d}$ (New York City Transit Authority, oral commun., 1984). Fourteen additional wells with a maximum pumping capacity of 20 $\mathrm{Mgal} / \mathrm{d}$ are planned in the East New York and Bedford sections of Kings County (New York City Transit Authority, oral commun., 1985). Undoubtedly homes, businesses, and institutions are dewatering also. Temporary dewatering is often required for the construction of underground structures, but no information is currently available. A total of about $8 \mathrm{Mgal} / \mathrm{d}$ is pumped for dewatering purposes in western Long Island $(6 \mathrm{Mgal} / \mathrm{d}$ in Kings and $2 \mathrm{Mgal} / \mathrm{d}$ in Queens) (New York City Department of Environmental Protection, oral commun., 1984). Therefore, a total of about 17 $\mathrm{Mgal} / \mathrm{d}$ is pumped for private purposes in Kings and Queens Counties.

The remaining discharge component of the ground-water budget, subsea outflow to the surrounding saltwater bodies, is considerably smaller than under predevelopment conditions but is still the largest discharge component. Because subsea discharge is impossible to measure, it is typically estimated as the flow rate required to balance the ground-water budget. Subsea outflow from the upper glacial and Jameco-Magothy aquifers at present is estimated to be $101 \mathrm{Mgal} / \mathrm{d}$; this value is corroborated by ground-water-flow model analysis (H. T. Buxton and D. A. Smolensky, U.S. Geological Survey, written commun. 1988). Subsea outflow from the Lloyd is negligible because pumping has lowered hydraulic heads throughout that aquifer in Kings and Queens, producing landward gradients.

\section{Ground-Water Quality}

The present quality of the ground water of western Long Island has been affected by more than 200 years of development and urbanization. The natural quality of Long Island's ground water (before man's influence) was the product of chemical constituents introduced with recharge from precipitation and natural geochemical reactions that occur between the ground water and the aquifer material. Present ground-water quality is affected further by contaminants introduced by human activities as well as by additional geochemical reactions. 
This study used the results of analyses of ground-water samples collected in 1983 to describe the present quality of ground water on western Long Island. An earlier, preliminary study by Buxton and others (1981) used results from a network of 77 observation wells supplemented by concurrent data from 67 public-supply wells provided by the Jamaica Water Supply Company. These samples were collected in 1981. In 1983, the network of observation wells sampled by the USGS was expanded to 107 wells (locations are shown on pl. 8). Samples were collected from June through October 1983; results are presented in table 10 (at end of report; 1981 data are included where available). Concurrent data from 84 publicsupply wells sampled during 1983 and analyzed by the Jamaica Water Supply Company are presented in table 11 (at end of report).

Chloride and nitrate concentration data are used to indicate the extent to which contamination from land surface and saltwater intrusion has propagated within the ground-water system. A brief summary of the distribution of other major inorganic constituents is provided in support of this analysis. In addition, concentrations of selected organic compounds detected in publicsupply wells of the Jamaica Water Supply Company are used to indicate the effect of these chemicals and related human activities on the groundwater system.

\section{Extent of Human-Induced Contamination}

In the following discussion, maps and vertical sections are used to provide a three-dimensional representation of (1) the extent to which land-surface contamination has migrated through the ground-water system, and (2) the extent to which the saltwater-freshwater interface has moved landward in all three major aquifers. Chloride and nitrate are used as indicators as described in the section "Deterioration of ground-water quality" (p. 24). Background concentrations of both are low, less than $10 \mathrm{mg} / \mathrm{L}$ and $0.2 \mathrm{mg} / \mathrm{L}$ as $\mathrm{N}$, respectively, compared to concentrations observed in 1983. The maps (figs. 12-14, p. 44-49) and cross sections (fig. 15, p. 50) can be evaluated in conjunction with the corresponding potentiometric maps (pl. 4, 5, and 6) and hydrogeologic sections (pl. 7), to indicate the extent of contamination in relation to the pattems of ground-water movement.
Contamination from land surface- - Nitrogen, in the form of nitrate, was one of the first contaminants to be introduced to the ground-water system; it entered as fertilizers and domestic waste dissolved in natural recharge. Even today, nitrate continues to enter the system through leakage from New York City's extensive combined-sewer network (Kimmel, 1972).

The shaded areas on the sections in figure 15 indicate the extent of ground water that has been affected by contamination from land surface. This area is defined on the assumption that nitrate has entered the system at the water table uniformly and consistently over the years and has migrated along natural ground-water flow paths through the system. Only three wells in the shaded area (Q2978, section D-D'; Q2418, section C-C'; and Q2137, section E-E') had nitrate concentrations less than $1.0 \mathrm{mg} / \mathrm{L}$, and $\mathrm{Q} 2418$, one of these wells, is affected by seawater intrusion. This format is used to indicate areas with a high expectation of contamination from land-surface sources and to provide a means to assess further migration of contaminated ground water.

Nitrate concentrations throughout the upper glacial aquifer indicate severe contamination that appears to decrease eastward (figs. 12B and 15). Concentrations in 19 of 35 samples from Kings County exceeded the public health standard of 10 $\mathrm{mg} / \mathrm{L}$, and concentrations in 27 of the 35 samples were greater than $5 \mathrm{mg} / \mathrm{L}$ (as $\mathrm{N}$ ). In Queens County, 8 of 39 samples had concentrations greater than $10 \mathrm{mg} / \mathrm{L}$ (as $\mathrm{N}$ ), and 24 exceeded $5 \mathrm{mg} / \mathrm{L}$ (as N). Of 11 samples from Nassau County, only 1 exceeded the public health standard, but 8 had concentrations of $3.7 \mathrm{mg} / \mathrm{L}$ (as $\mathrm{N}$ ) or higher.

Nitrate concentrations in samples from only 2 of 72 wells in the Jameco-Magothy aquifer were greater than $10 \mathrm{mg} / \mathrm{L}$ (as $\mathrm{N}$ ). The distribution of these values is plotted in figure 13B (p. 47). Of 69 samples from wells in Queens and Nassau Counties that were not affected by seawater, 12 were from wells in the area where the Gardiners Clay separates the Jameco-Magothy and upper glacial aquifers. The highest nitrate concentration in these wells was $0.79 \mathrm{mg} / \mathrm{L}$, and all but two wells had concentrations of $0.28 \mathrm{mg} / \mathrm{L}$ or less. Of the 47 samples taken from inland wells where the Gardiners Clay is absent, 34 had nitrate concentrations greater than $2 \mathrm{mg} / \mathrm{L}$ (as $\mathrm{N}$ ). 
The Gardiners Clay slows the downward movement of ground water, which suggests that water in the Jameco-Magothy aquifer beneath this confining unit is older than in areas where the unit is absent. Section D-D' (fig. 15) illustrates the difference between nitrate concentrations in the part of the Jameco-Magothy aquifer that is confined and protected by the Gardiners Clay and those in the part that is in good hydraulic connection with the upper glacial aquifer. Sections C-C' and E-E' (fig. 15) both show large areas where the confining unit is absent, and nitrate concentrations in the Jameco-Magothy aquifer indicate contamination from land-surface sources.

The Jameco-Magothy aquifer in Kings County is completely overlain by the Gardiners Clay. As noted previously, however, the Gardiners Clay is much sandier in Kings than in Queens and would inhibit vertical flow much less. Samples from four of six wells that tap the Jameco-Magothy in Kings County had nitrate concentrations ranging from 6 $\mathrm{mg} / \mathrm{L}$ to more than $10 \mathrm{mg} / \mathrm{L}$, which suggests that, as expected, flow rates through the Gardiners Clay are more rapid in Kings County than in Queens.

Of the 14 samples from the Lloyd aquifer, 12 had nitrate concentrations ranging from less than 0.1 to $0.72 \mathrm{mg} / \mathrm{L}$ in 1983; this indicates little, if any, contamination from land surface. The absence of land-surface contamination in the Lloyd aquifer is attributed to the aquifer's greater depth and to separation from overlying aquifers by the Raritan confining unit. Franke and Cohen (1972) estimated that the age of water in the Lloyd aquifer was 1,000 to 10,000 years -1 or 2 orders of magnitude older than water in the shallower aquifers. Therefore, this water entered the ground-water flow system (at the water table) long before the contamination from land surface appeared.

Two factors suggest that water in the Lloyd aquifer in westem Long Island could be younger than that farther east, however. The first is the erosional channel that cuts through the Raritan confining unit in central Queens County and forms a pathway for more rapid vertical movement of ground water downward to the Lloyd aquifer. (The area where Raritan and Lloyd deposits were eroded away and subsequently replaced by glacial material is shaded in figs. 14A and 14B; the erosional channel also is indicated in the sections in fig. 15.) The second factor is that the Lloyd aquifer in Kings and Queens Counties has been pumped since the turn of this century, and the increased downward gradients caused by this pumping have probably accelerated vertical ground-water movement. The sections in figure 15 indicate that, even though water affected by man has not yet reached the Lloyd aquifer, the pathway for downward movement through the eroded channel in the Raritan confining unit could allow it to reach there within decades rather than the millennia it could take to move through the confining unit.

Saltwater intrusion.-Ground water that has been affected by seawater is readily identified by elevated chloride along with other principal constituents of seawater (sodium, sulfate, and hardness) and low nitrate concentrations. Total nitrogen concentration (as nitrate, nitrite, ammonia, and nitrogen gas) in seawater is $0.5 \mathrm{mg} / \mathrm{L}$ (as $\mathrm{N}$ ) (Hem, 1970, p. 11). Concentrations of chloride and nitrate and the other principal constituents of seawater were used to define the general position of the zone of diffusion of the saltwater-freshwater interface.

A history of intense pumping in Kings and westem Queens Counties has caused the zone of diffusion in westem Long Island to become more dispersed than anywhere else on Long Island. In some areas, the residue of past seawater intrusion extends far inland and undoubtedly contributes to contamination that, when combined with elevated nitrate concentrations, appears to be solely of land-surface origin. Delineation of areas that have been affected by both seawater and land-surface contaminants was beyond the scope of this study, however.

Chloride concentrations in the upper glacial aquifer ranged from 13 to $9,000 \mathrm{mg} / \mathrm{L}$ in 1983 (fig. 12A). Chloride concentrations in inland areas of Kings and southwestern Queens County differ locally in an erratic fashion-concentrations of less than $20 \mathrm{mg} / \mathrm{L}$ can be found close to concentrations well over $200 \mathrm{mg} / \mathrm{L}$. This probably indicates a combination of past saltwater intrusion and landsurface-derived contamination. In contrast, chloride concentrations in inland parts of eastem Queens and Nassau Counties range from 16 to 86 $\mathrm{mg} / \mathrm{L}$ and do not indicate saltwater intrusion. Most samples with chloride concentrations above 250 $\mathrm{mg} / \mathrm{L}$ were from nearshore areas and indicate the 
landward extent of the zone of diffusion of the saltwater interface. The saltwater interface, as a lateral boundary to the fresh ground-water system and as mapped in figures $13 \mathrm{~A}$ and $14 \mathrm{~A}$, is assumed to coincide with a chloride concentration of about $1,000 \mathrm{mg} / \mathrm{L}$.

The three sections in figure 15 show that the saltwater interface in the upper glacial aquifer is close to shore. The elevated chloride concentration at well Q2418 (section C-C') indicates that it possibly is being drawn landward from Flushing Bay (fig. 12A, p. 44).

The distribution of chloride in samples from the Jameco-Magothy aquifer is shown in figure 13A (p. 46). The interface configuration is based on the average values for the entire thickness of the aquifer and gives a general indication of the extent of saline ground water in plan view. The vertical configuration of the interface is shown in the hydrogeologic sections in figure 15 (p. 50). The interface is expected to advance landward with depth, but data on chloride concentrations at the base of the Magothy aquifer are too sparse to indicate the landward extent of the toe of the interface. Additional monitoring wells at the base of the Jameco-Magothy aquifer would be needed to ensure that saltwater intrusion has not progressed significantly farther inland there than in the shallower parts of the aquifer. The interface is estimated to have migrated inland in southern Queens and southwestern Nassau Counties in response to the extensive pumping in southeastern Queens and Nassau Counties during recent years. Elevated concentrations in wells K2510 and K2511, in the extreme south of Kings County (pl. 8 and fig. 13A), indicate that the saltwater interface in the Jameco-Magothy aquifer is inland in Kings County as well. Chloride concentrations as high as $500 \mathrm{mg} / \mathrm{L}$ in samples from inland wells in Kings County indicate a residue of past saltwater intrusion.

Chloride concentrations at inland wells in Queens County are much lower than in Kings. Only eight Queens wells had chloride concentrations exceeding $100 \mathrm{mg} / \mathrm{L}$, probably because pumping has been continually shifted eastward to avoid severe saltwater intrusion locally. Except at three wells screened near the saltwater-freshwater interface, chloride concentrations in Nassau County wells were less than $50 \mathrm{mg} / \mathrm{L}$.
The Jameco-Magothy aquifer could have a potential for saltwater intrusion from the north shore near Flushing Bay, where the aquifer is close to land surface and glacial deposits form a good hydraulic pathway for saltwater intrusion (fig. 15, section $\mathbf{C}-\mathbf{C}^{\prime}$ ).

In the Lloyd aquifer, chloride concentrations in samples from inland wells range from 3 to 16 $\mathrm{mg} / \mathrm{L}$, within the predevelopment range. Three samples taken along the south shore of Kings and Queens Counties had chloride concentrations between 50 and $100 \mathrm{mg} / \mathrm{L}$, which probably indicates the farthest landward extent of the saltwaterfreshwater interface. These data are insufficient to indicate how rapidly the chloride concentrations increase seaward, however. The configuration of the interface, as shown in figure $14 \mathrm{~A}(\mathrm{p} .48)$ is estimated.

As shown in the sections in figure 15 , the interface in the Lloyd aquifer on the north shore is close to the northem edge of the Raritan confining unit, which in this area is close to the shore. Several wells on the north shore have elevated chloride concentrations, indicating possible saltwater intrusion. Well Q1373 in College Point (pl. 8) had a chloride concentration of $1,200 \mathrm{mg} / \mathrm{L}$ in 1983. This well, along with well Q1374 (not sampled) at the same location and depth, were industrial pumping wells drilled in 1946. This pumping induced the saltwater to move into the College Point area. Soren (1971) reports that Q1374 had a chloride concentration of $1,718 \mathrm{mg} / \mathrm{L}$ in 1955 .

The extensive regional cone of depression in the Lloyd aquifer could be sufficient to induce saltwater intrusion from the north as well as the south shore. Saline ground water could affect the Lloyd aquifer (fig. 15) either by lateral movement of the interface from its current position in the Lloyd or by vertical migration through the channel in the Raritan confining unit. Well Q3134 (figs. 14A and section $\mathrm{C}^{-C^{\prime}}$ in fig. 15), in the erosional channel in the Raritan confining unit near Flushing Bay, had a chloride concentration of $500 \mathrm{mg} / \mathrm{L}$ in 1983 . Saline ground water probably was drawn into the Flushing area during the 1964-65 World's Fair, when large-scale ground-water withdrawals occurred (Soren, 1971, p. A32). Additional discussion of the movement of the saltwater-freshwater interface is given in the earlier section, "Water-Table and Potentiometric-Surface Altitudes." 


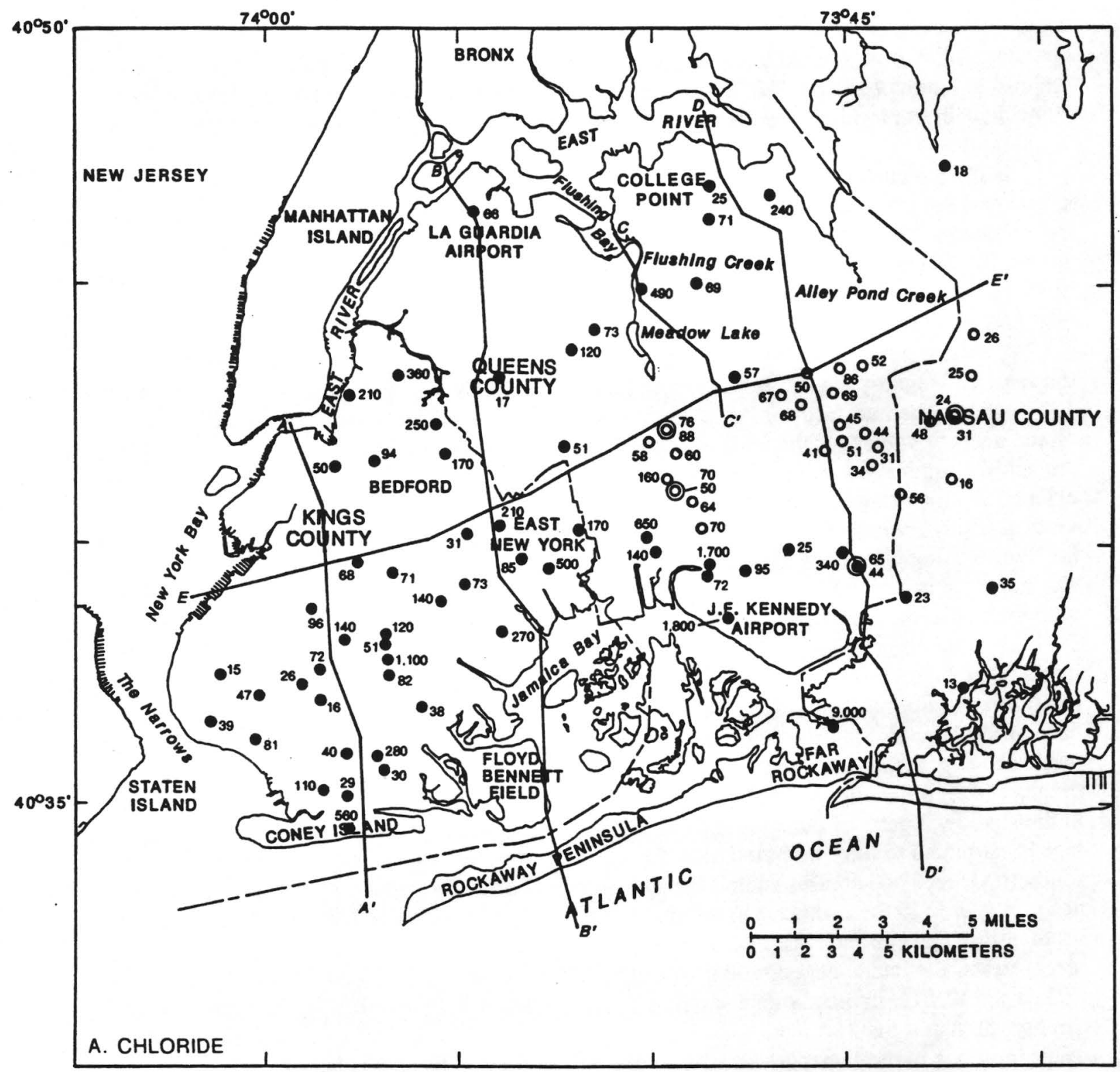

\section{EXPLANATION}

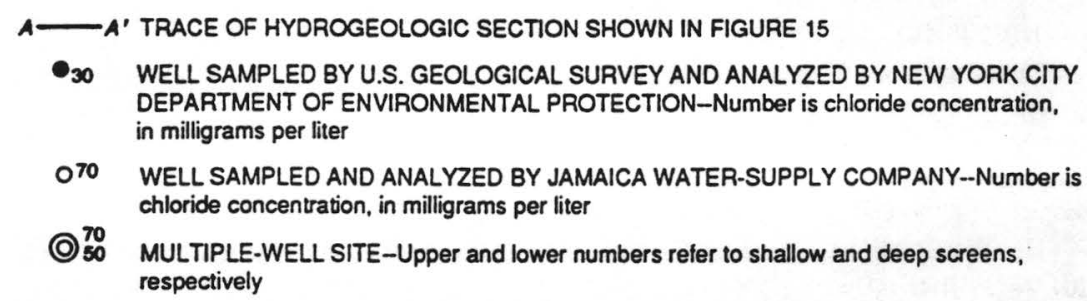

Figure 12A. Chloride concentrations in the upper glacial aquifer, 1983. 


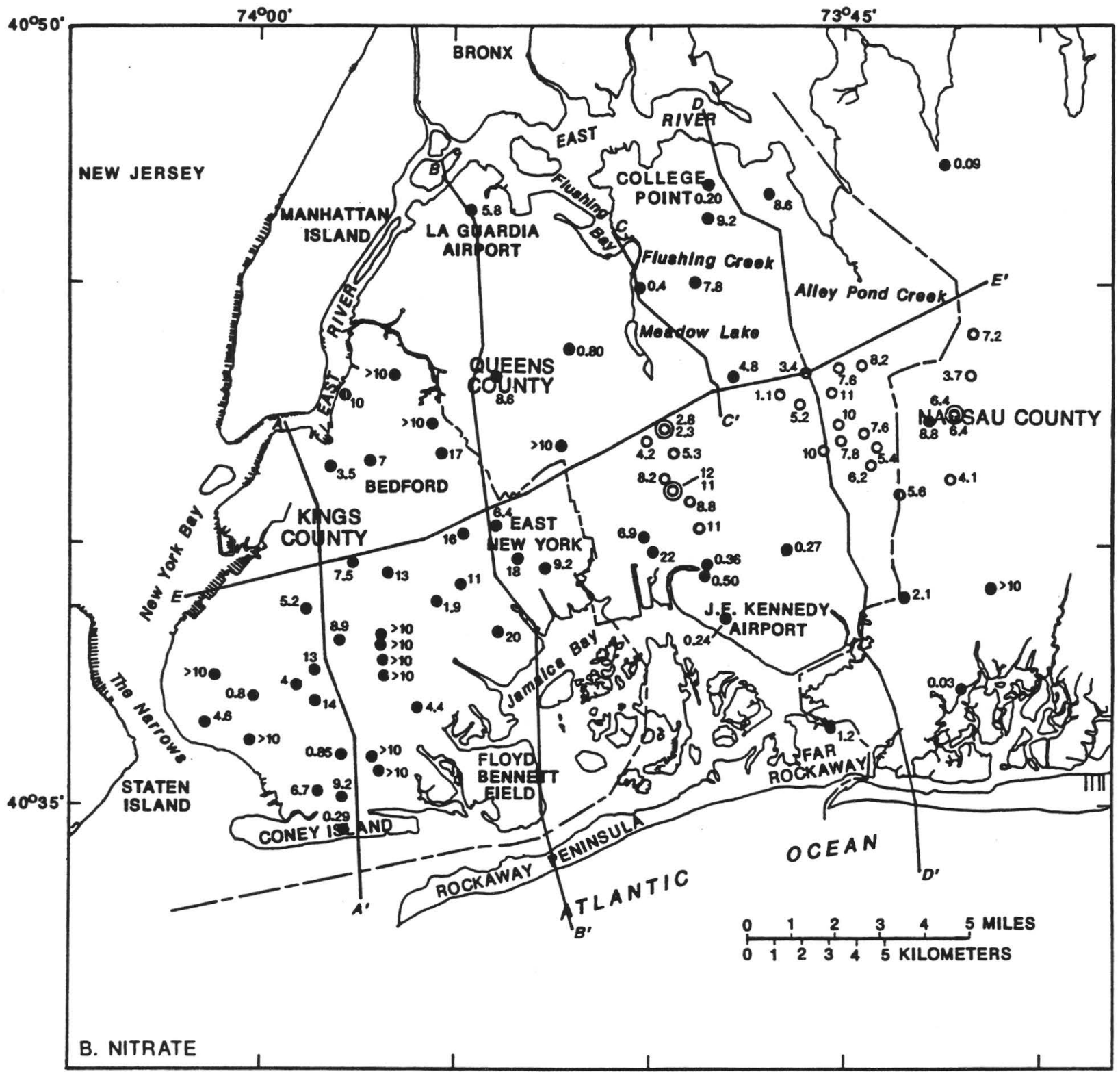

EXPLANATION

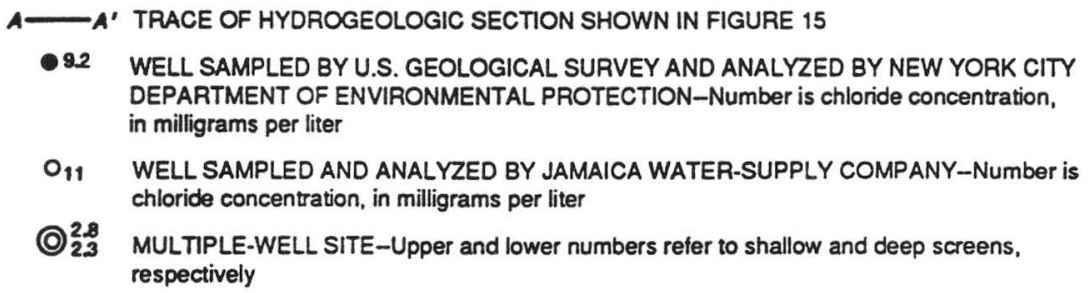

Figure 12B. Nitrate concentrations in the upper glacial aquifer, 1983. 


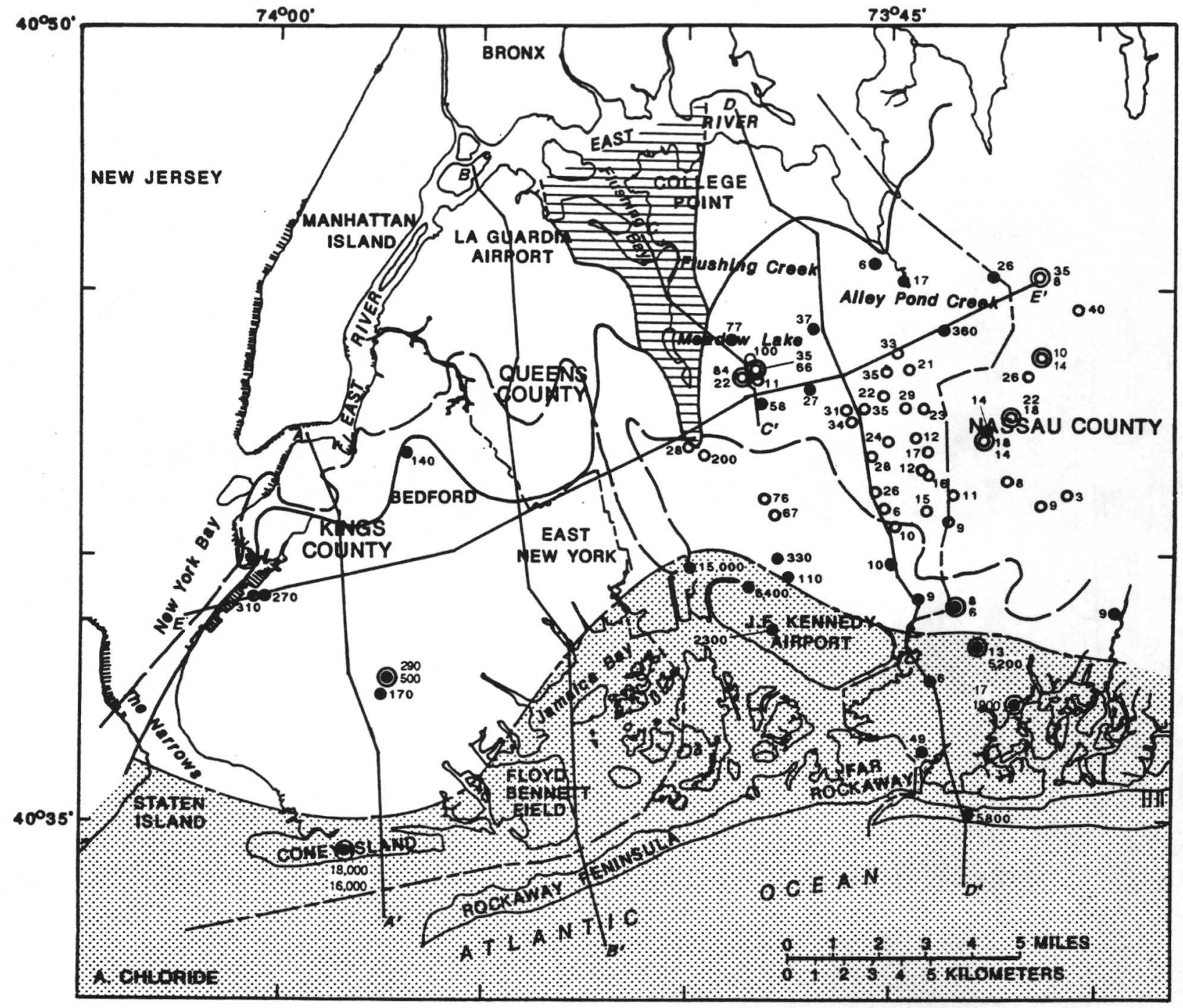

\section{EXPLANATION}

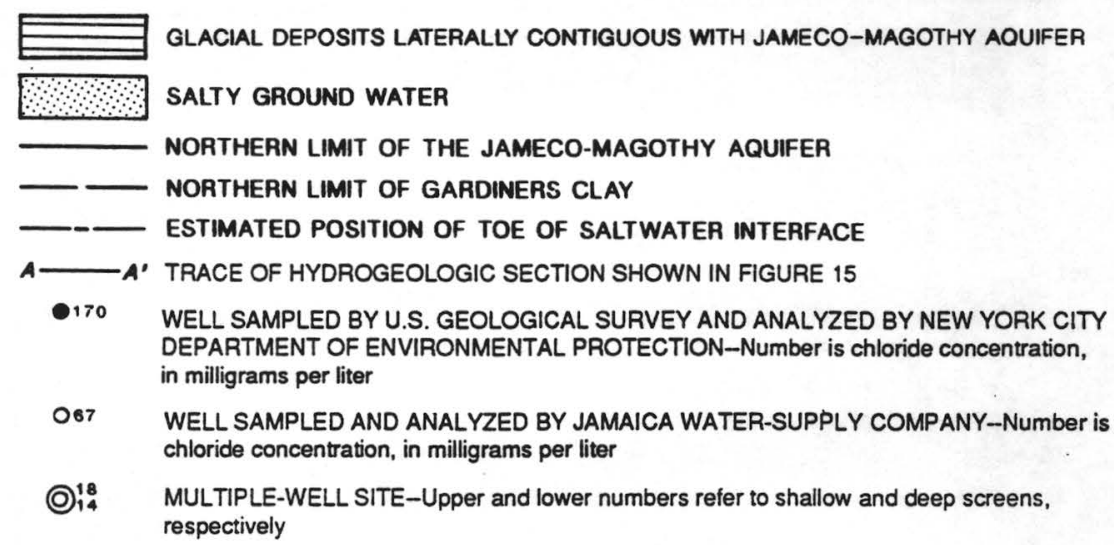

Figure 13A. Chloride concentrations in the Jameco-Magothy aquifer, 1983. 


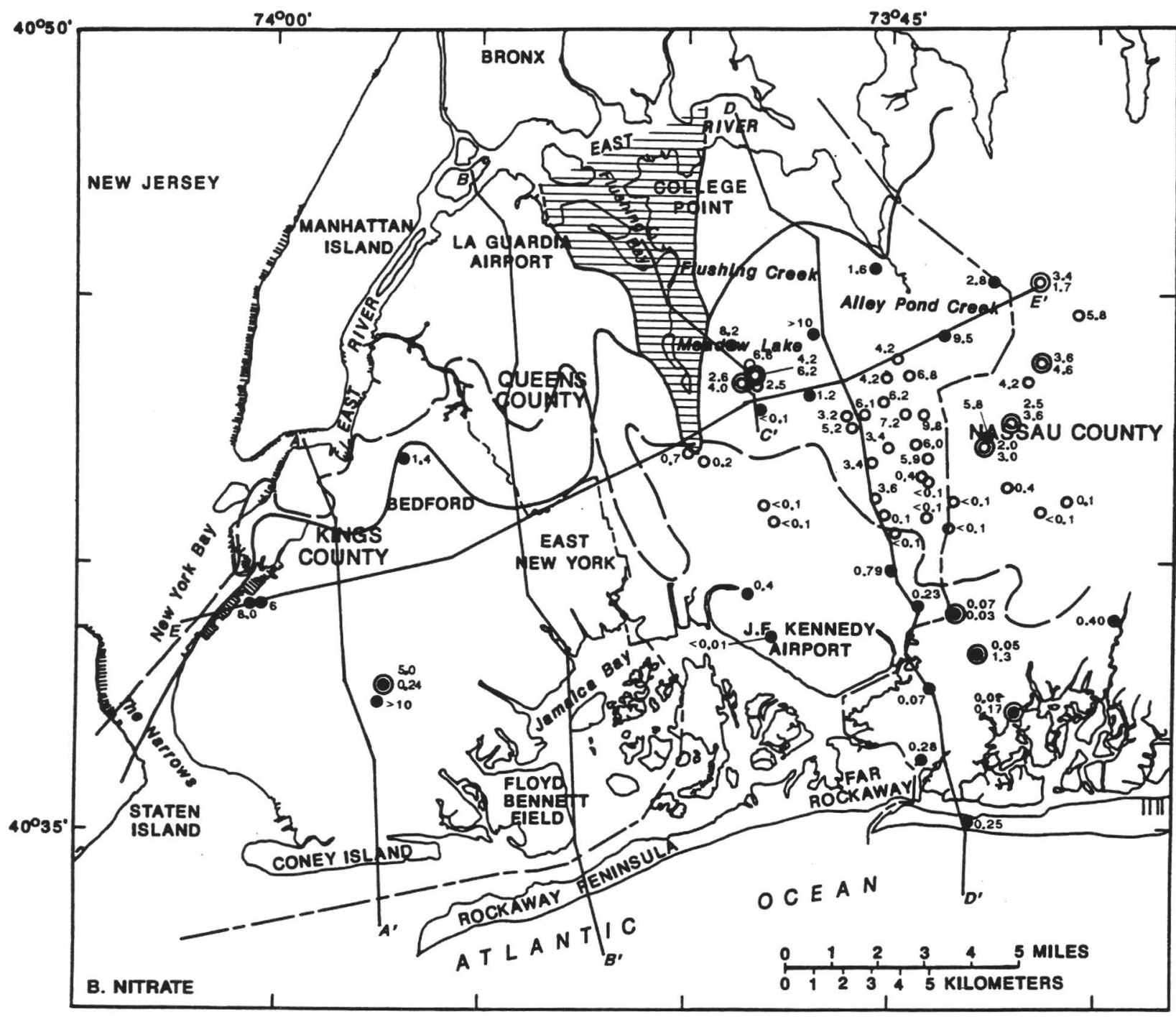

EXPLANATION

glacial deposits lateraliy Contiguous With Jameco-magothy AQuifer

- NORTHERN LIMIT OF JAMECO-MAGOTHY AQUIFER

— NORTHERN LIMIT OF GARDINERS CLAY

$A$ A' TRACE OF HYDROGEOLOGIC SECTION SHOWN IN FIGURE 15

$\bullet>10$ WELL SAMPLED BY U.S. GEOLOGICAL SURVEY AND ANALYZED BY NEW YORK CITY DEPARTMENT OF ENVIRONMENTAL PROTECTION-Number is chloride concentration, in milligrams per liter

O3.4 WELL SAMPLED AND ANALYZED BY JAMAICA WATER-SUPPLY COMPANY-Number is chloride concentration, in milligrams per liter

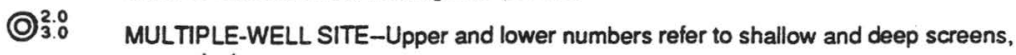
respectively

Figure 13B. Nitrate concentrations in the Jameco-Magothy aquifer, 1983. 


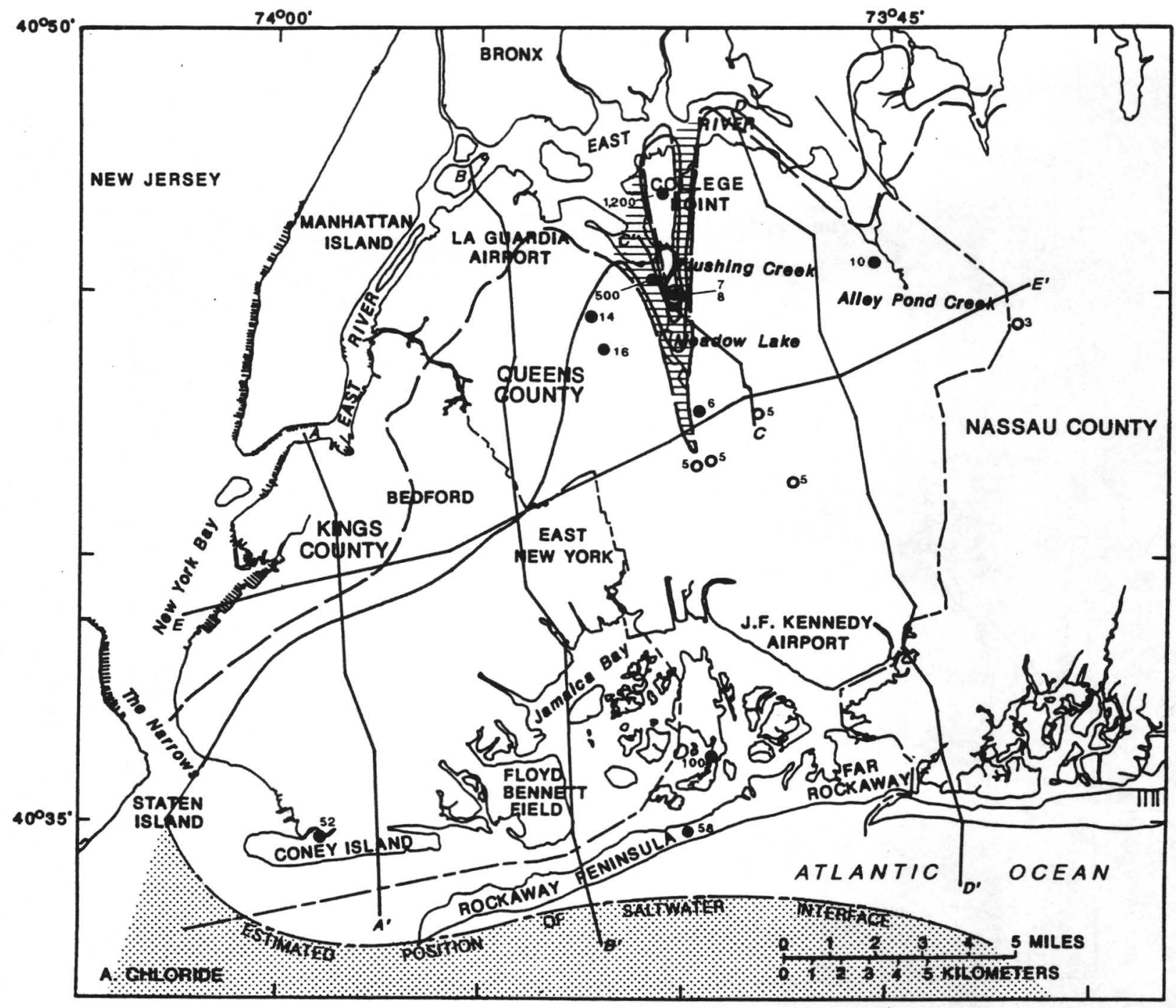

\section{EXPLANATION}

GLACIAL DEPOSITS LATERALLY CONTIGUOUS WITH LLOYD AQUIFER

SALTY GROUND WATER

- NORTHERN LIMIT OF THE LLOYD AQUIFER

- NORTHERN LIMIT OF THE RARITAN FORMATION OF THE CLAY MEMBER

A-A' TRACE OF HYDROGEOLOGIC SECTION SHOWN IN FIGURE 15

52 WELL SAMPLED BY U.S. GEOLOGICAL SURVEY AND ANALYZED BY NEW YORK CITY DEPARTMENT OF ENVIRONMENTAL PROTECTION-Number is chloride concentration, in milligrams per liter

O 5 WELL SAMPLED AND ANALYZED BY JAMAICA WATER-SUPPLY COMPANY-Number is chioride concentration, in milligrams per liter

O ${ }_{8}^{7} \quad$ MULTIPLE-WELL SITE-Upper and lower numbers refer to shallow and deep screens respectively

Figure 14A. Chloride concentrations in the Lloyd aquifer, 1983. 


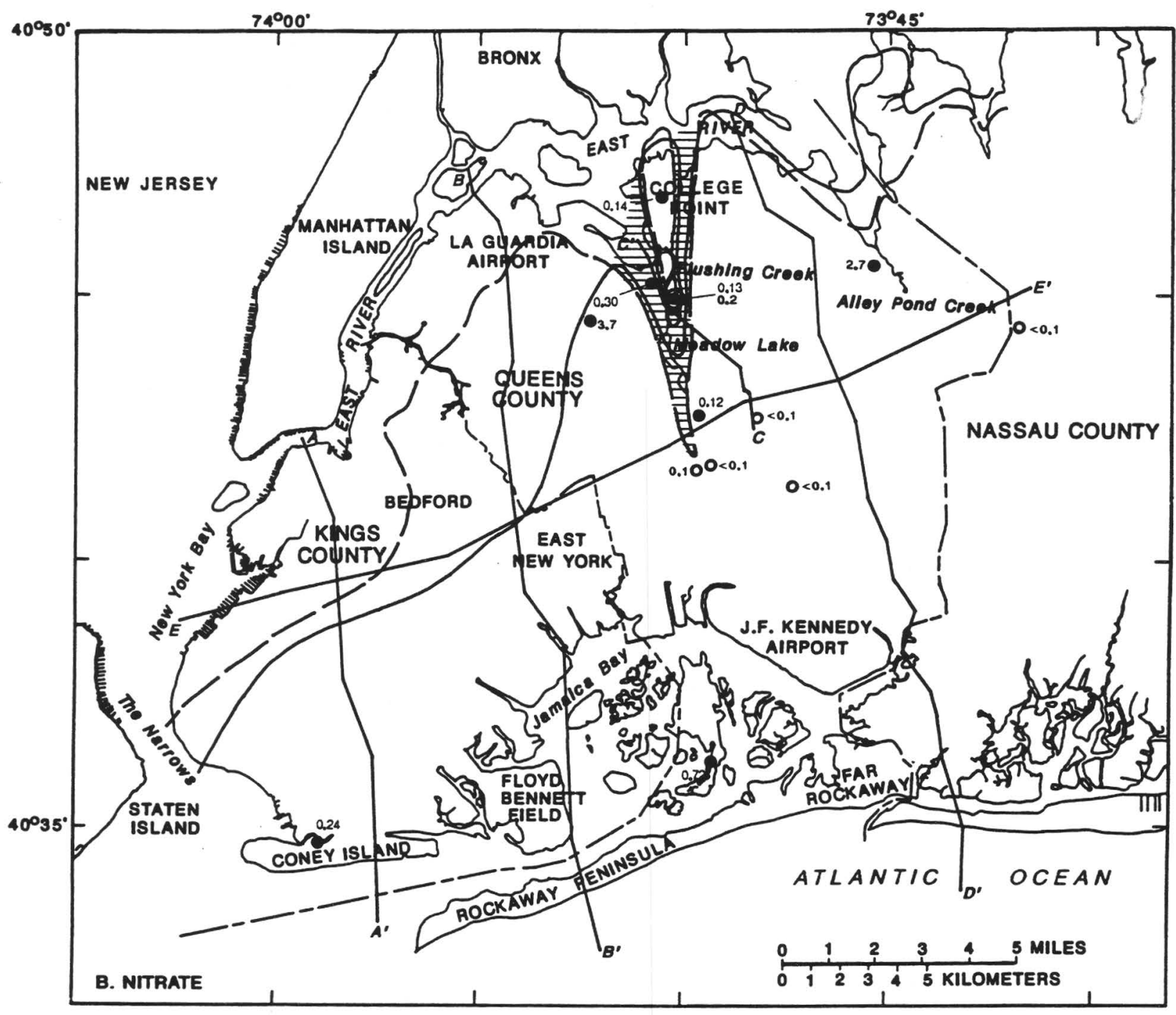

EXPLANATION

GLACIAL DEPOSITS LATERALLY CONTIGUOUS WITH LLOYD AQUIFER

- NORTHERN UMIT OF THE LLOYD AQUIFER
NORTHERN LIMIT OF THE RARITAN FORMATION OF THE CLAY MEMBER

A-A' TRACE OF HYDROGEOLOGIC SECTION SHOWN IN FIGURE 15

224 WELL SAMPLED BY U.S. GEOLOGICAL SURVEY AND ANALYZED BY NEW YORK CITY DEPARTMENT OF ENVIRONMENTAL PROTECTION-Number is chloride concentration, in milligrams per liter

O0.1 WELL SAMPLED AND ANALYZED BY JAMAICA WATER-SUPPLY COMPANY-Number is chloride concentration, in milligrams per liter

$\mathrm{O}_{0.2}^{13}$ MULTIPLE-WELL SITE-Upper and lower numbers refer to shallow and deep screens.
respectively

Figure 14B. Nitrate concentrations in the Lloyd aquifer, 1983. 


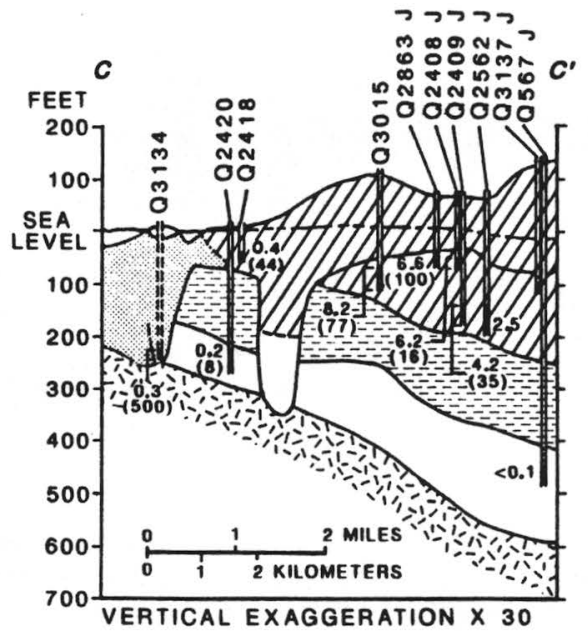

\section{EXPLANATION}

DIII] AREA WHERE NITRATE CONCENTRATION IS EXPECTED TO EXCEED 1.0 MILLIGRAMS PER LITER (AS N)

AREA OF SALTY GROUND WATER--Chloride concentration exceeds 1,000 milligrams per liter. Zone of diffusion extends inland where concentrations are less than 1,000 milligrams per liter

CONFINING UNIT

ESI:S BEDROCK
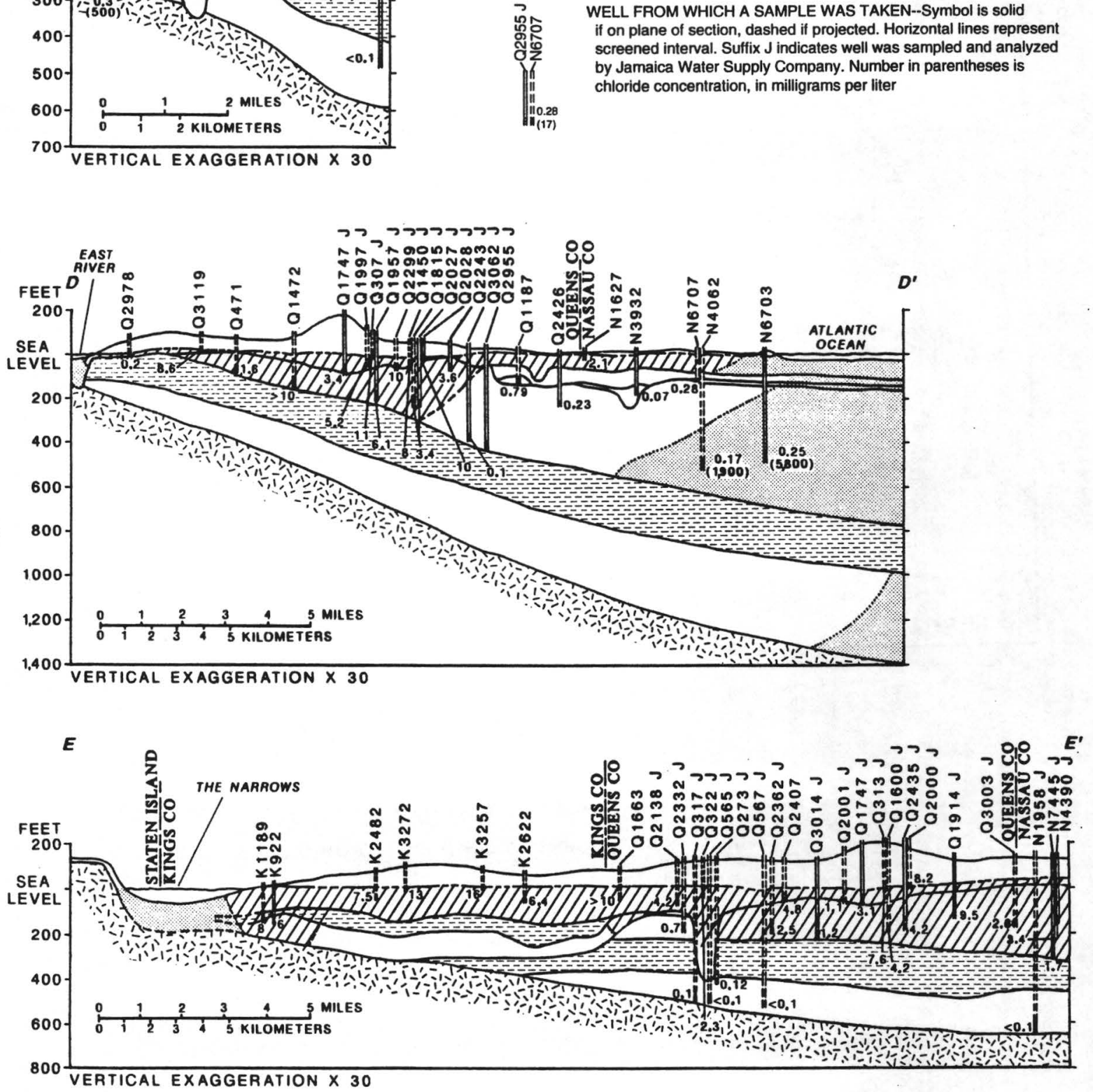

Figure 15. Nitrate and chloride concentrations along sections $C-C^{\prime}, D-D^{\prime}$, and $E-E^{\prime}$. (Trace of sections is shown on pl. 7.) 


\section{Inorganic Constituents}

As described in the previous section, two general trends are observed in the concentrations of human-induced inorganic constituents in ground water in westem Long Island. Concentrations tend to decrease eastward in each aquifer and also with depth at any location. These trends reflect the facts that (1) development began in westem Kings County and progressed eastward, and (2) land use today ranges from intense urbanization in Kings to mixed residential-industrial use in westem Nassau. These trends in individual aquifers are discussed in the following paragraphs.

Upper Glacial Aquifer.-The analyses of samples from 96 wells in the upper glacial aquifer during 1983 (table 10, at end of report) indicate that human activities have altered the ground water's natural chemical composition. The dissolved-solids concentration, a measure of all chemical constituents dissolved in ground water, is elevated throughout the upper glacial aquifer in Kings and Queens; all samples had concentrations greater than $100 \mathrm{mg} / \mathrm{L}$. Under natural conditions, the dissolved-solids concentration is extremely low, generally below $35 \mathrm{mg} / \mathrm{L}$ (table 3). These data indicate that the public-health standard of 500 $\mathrm{mg} / \mathrm{L}$ is exceeded at 33 wells -18 in Kings and 15 in Queens.

Hardness values have risen since development (table 3). Predevelopment concentrations in Kings and Queens Counties were less than $25 \mathrm{mg} / \mathrm{L}$ (as $\mathrm{CaCO}_{3}$ ), but 1983 values ranged from 42 to 3,100 $\mathrm{mg} / \mathrm{L}$ (except one sample, which had $20 \mathrm{mg} / \mathrm{L}$ ). Except for five wells that were considered to be significantly affected by seawater (chloride and hardness concentrations $650 \mathrm{mg} / \mathrm{L}$ or above), hardness values ranged from 20 to $740 \mathrm{mg} / \mathrm{L}$ in Kings County, from 42 to $440 \mathrm{mg} / \mathrm{L}$ in Queens, and from 54 to $250 \mathrm{mg} / \mathrm{L}$ in Nassau. Higher concentrations in Kings are caused at least in part by a residue of saltwater intrusion from the 1940's.

Fluoride concentrations are extremely low in ground water throughout Kings and Queens Counties. Natural concentrations are $0.5 \mathrm{mg} / \mathrm{L}$ or less and are probably derived from dissolution of amphibole, homblende, and mica (Hem, 1970). Most groundwater contaminants (manmade waste and saltwater) do not contain significant concentrations of fluoride. Seven wells in Kings and Queens had fluoride concentrations ranging from 0.8 to $1.0 \mathrm{mg} / \mathrm{L}$.
Fluoride is added to the drinking-water supply of New York City at an average concentration of 0.93 mg/L (New York City Department of Environmental Protection, written commun., 1984). Therefore, these concentrations could indicate leakage from water-supply lines.

Sulfate concentrations are considerably higher than in predevelopment times, when they were less than $12 \mathrm{mg} / \mathrm{L}$ (table 3). Only 3 of 67 wells in Kings and Queens in 1983 had sulfate concentrations less than $12 \mathrm{mg} / \mathrm{L}$, the maximum observed value in samples representative of predevelopment conditions. Samples from the remaining wells, excluding two affected by seawater, ranged from 15 to $200 \mathrm{mg} / \mathrm{L}$ and averaged about $75 \mathrm{mg} / \mathrm{L}$. No distinct east-west trend is evident from these data.

Jameco-Magothy Aquifer.-Analyses of samples from 80 wells screened in the MagothyJameco aquifer are available. Eight of these are in Kings County (all are screened in the Jameco), 47 are in Queens, and 25 are in Nassau.

The dissolved-solids concentrations of almost all samples from the Jameco-Magothy aquifer exceed predevelopment levels. The eight samples from Kings County had the highest concentrations-all were above the $500-\mathrm{mg} / \mathrm{L}$ public-health standard. The dissolved-solids concentrations in 39 of 44 samples from Queens County were below the public health standard, and 28 were below 250 $\mathrm{mg} / \mathrm{L}$. Wells in Nassau County showed still lower dissolved-solids concentrations. Except for two samples that were affected by seawater, concentrations in 17 samples ranged from 32 to $224 \mathrm{mg} / \mathrm{L}$.

The hardness of samples ranged from a low of $8 \mathrm{mg} / \mathrm{L}$ (as $\mathrm{CaCO}_{3}$ ) in Nassau County to a high of $14,000 \mathrm{mg} / \mathrm{L}$ in a well affected by seawater in southem Queens. Except for nine wells affected by seawater (chloride and hardness concentrations of $1,100 \mathrm{mg} / \mathrm{L}$ or above), values ranged from moderately hard to hard, averaging $330 \mathrm{mg} / \mathrm{L}$ in Kings County, $140 \mathrm{mg} / \mathrm{L}$ in Queens, and $38 \mathrm{mg} / \mathrm{L}$ in westem Nassau.

Sulfate concentrations in the Jameco-Magothy aquifer were slightly above predevelopment concentrations but were lower than those in the upper glacial aquifer. Except for the same nine wells that were affected by seawater, sulfate concentrations were less than $100 \mathrm{mg} / \mathrm{L}$ in Kings County, less than $110 \mathrm{mg} / \mathrm{L}$ in Queens, and less than $63 \mathrm{mg} / \mathrm{L}$ in Nassau. 
Lloyd Aquifer:-Analyses are available from only 15 wells screened in the Lloyd aquifer (which has only a few wells because drilling to that depth is costly, and water is generally available from the other aquifers.) Of these wells, 13 are in Queens County, 1 is in Kings, and 1 is in western Nassau. One well (Q1373, pl. 8), on the north shore of Queens County, where the Lloyd aquifer is close to land surface, is affected by seawater, at the remaining 14 wells, the total dissolved-solids concentration was $265 \mathrm{mg} / \mathrm{L}$ or less and, at 7 wells, was $100 \mathrm{mg} / \mathrm{L}$ or less. Hardness at those 14 wells was less than 65 $\mathrm{mg} / \mathrm{L}$, and sulfate concentrations were less than 35 $\mathrm{mg} / \mathrm{L}$; in 10 wells they were less than $20 \mathrm{mg} / \mathrm{L}$.

\section{Organic Constituents}

The widespread use of a variety of organic compounds in highly industrialized and urbanized areas of westem Long Island has created concem over the potential for ground-water contamination. Even though the toxicity of many organic compounds is unknown, their distribution is a critical factor in decisions as to where ground water is safe for drinking.

No extensive ground-water-sampling effort has been undertaken in Kings or Queens Counties to date to document the presence of organic compounds; only ground water pumped in southeastern Queens by the Jamaica Water Supply Company is routinely monitored for organic compounds. This monitoring began in 1979 and is under the auspices of the New York City Department of Health. Results indicate contamination by organic compounds. During the fall and winter of 1983 , when 54 wells of the Jamaica Water Supply Company were sampled for total volatile organic compounds, 42 showed detectable levels (detection limit 0.1 parts per billion, ppb) (New York City Department of Health, 1984.) Of these 42 wells, two exceeded the recommended guidelines set by the New York City Department of Health (1984) and were ordered closed by that department. Since the Department of
Health began monitoring in 1979, it has ordered 14 wells closed for exceeding the guidelines; 12 of these wells are screened in the upper glacial aquifer, and the remaining two in the Magothy aquifer. The closed wells could be monitored and reopened if the concentrations of organic compounds drop below the recommended guidelines.

Detectable levels of organic contamination have been found mostly in the upper glacial and Magothy aquifers, where most of the pumping occurs. The New York City Department of Health (1984) reports that, in 1983, detectable levels of contamination were found at 22 of 23 wells screened in the upper glacial aquifer, at 19 of 25 wells screened in the Magothy aquifer, and at 1 of 4 wells screened in the Lloyd aquifer. Two wells screened in the Jameco aquifer showed no contamination.

The New York City Department of Health (1984) also reports that samples from 28 contaminated wells contained more than one organic compound; a total of 16 different volatile organic compounds were detected in 1983.

Data from southeastern Queens County indicate that organic compounds have migrated through the upper glacial aquifer and into the Jameco-Magothy aquifer. Many of the organic compounds enter the ground-water system from sporadic, dispersed point sources, which makes correlation extremely difficult. In fact, some wells found not to have detectable levels of organic compounds at one sampling may contain detectable levels at a subsequent sampling as sporadic and irregular plumes pass the well screen. These data are few, however, and whether the conclusions drawn from them can be applied to the rest of westem Long Island is uncertain. Yet, ground water that contains other indicators of land-surface contamination, as described in the previous section, would have the highest probability of containing organic compounds as well.

\section{GROUND-WATER-RESOURCE CONCERNS}

The hydrologic conditions observed in 1983 indicate that pumping has caused an extensive cone of depression in all three major aquifers. Whether current pumping exceeds the safe yield of the aquifer system is difficult to determine until unaccept- able levels of specific undesirable hydrologic effects of development have been identified and measured. Undesired results of ground-water development on western Long Island include severe water-level declines, intrusion of saline 
ground water, downward migration of land-surface contamination into confined aquifers, and flooding of underground structures. The first three are closely related in that extreme drawdown that results from pumping of deep aquifers will increase the rate of landward movement of the saltwaterfreshwater interface and the rate of downward movement of contaminants (introduced at the water table) into confined aquifers. The major result of these undesired effects is that the potable groundwater supply would be continually diminished.

The data in this report indicate that the saltwater-freshwater interface is moving landward and that contaminants in shallow aquifers are moving into the confined aquifers. Any increase in pumping will accelerate these effects to some extent, however, a realistic resource-management strategy could include location of wells in inland areas beyond the threat of saltwater intrusion, and beneath the extent of migration of land-surface contaminants which would prolong the period until treatment is needed to maintain an adequate supply of potable water.

With the liklihood of additional decreases in ground-water pumping,flooding of underground structures by rising water levels is another serious concern. Such flooding is already occurring in areas where pumping has been curtailed and could extend farther if present pumping rates are reduced. Reducing ground-water pumpage while increasing the use of upstate surface water would require monitoring of ground-water levels, especially near shores and buried stream channels, where depths to water are smallest. Redistribution of pumping for public supply can provide a means to mitigate both severe drawdown in the east and excessive water levels farther west, but significant financial, institutional, and water-quality considerations would need to be resolved first.

Ground-water quality is worst in the westernmost and shallowest parts of the aquifer system but improves eastward and with depth. Potable ground water is still largely available in eastern Queens, even from the upper glacial aquifer, but probably not in areas farther west. The Lloyd aquifer, which is still uncontaminated, cannot greatly supplement the supply because it is sensitive to pumping and is expected to yield only small volumes of water without incurring excessive drawdown. Therefore, redistribution of ground-water pumping, even at current rates, would probably require some treatment to ensure potable quality.

In 1983 , only about $60 \mathrm{Mgal} / \mathrm{d}$, or 8 percent, of the $750 \mathrm{Mgal} / \mathrm{d}$ used for public supply in Kings and Queens Counties was derived locally from ground water, the remainder was supplied from an upstate surface-water-reservoir system. A conjunctiveresource-development strategy that takes advantage of the inherent differences in the nature of groundwater and surface-water systems could enable a reduction in the harmful effects of the present development strategy. At present, water is developed continuously from both sources and used in separate areas. The use of ground water as a periodic supplement to the surface-water supply could result in a combined system with greater productivity than the separate ground- and surface-watersupply systems as they are operated at present.

\section{SUMMARY}

The aquifers underlying Kings and Queens Counties supplied an average of about $120 \mathrm{Mgal} / \mathrm{d}$ during 1904-47. Intensive pumping in Kings County during the 1930's lowered ground-water levels and caused intrusion of saline ground water into the upper glacial and Jameco-Magothy aquifers until 1947, when all pumping for public supply in the county was stopped. Subsequently, pumping in Queens County has been increased. A severe cone of depression that developed in southwestern Queens County during the 1960's also caused intrusion of saline ground water, as a result, pumping for public supply in the Woodhaven franchise area of the New York Water Supply Company was halted in 1974. Pumping for public supply has persisted in eastern Queens County, where the Jamaica Water Supply Company has pumped an average of about $60 \mathrm{Mgal} / \mathrm{d}$ since 1974.

Since the cessation of pumping in Kings and southwestern Queens, ground-water leveis have been recovering steadily. In 1983, ground-water levels in Kings were close to predevelopment levels, and contamination by saltwater had partly dispersed and become diluted. An extensive cone of depression remains in all three major aquifers in eastern Queens County, however. The saltwater- 
freshwater interface in the Jameco-Magothy

aquifer, which is already inland, is moving toward the center of pumping. Available data indicate that saline ground water in the Lloyd aquifer is not far offshore and is also moving landward.

At present, elevated nitrate and chloride concentrations throughout the upper glacial aquifer indicate widespread contamination from land surface. Some contamination in the Jameco-Magothy aquifer is attributed to downward migration in areas of substantial hydraulic connection between aquifers (where the Gardiners Clay is absent). A channel eroded through the Raritan confining unit provides a pathway for migration of contaminants to the Lloyd aquifer. The cone of depression in the Lloyd has increased the downward gradients through this channel, which could cause contami- nants to enter the Lloyd sooner than anticipated.

Although chloride and nitrate have been used as the principal indicators of ground-water contamination, other constituents introduced from point sources also may affect ground-water quality locally. The extent to which nitrate and chloride from the land surface have moved through the ground-water system indicates that treatment eventually could be needed to ensure the quality of water pumped from the upper glacial or JamecoMagothy aquifers. Ground water in the Lloyd aquifer is still largely uncontaminated, but present pumpage and ground-water levels indicate that this aquifer is much more sensitive to withdrawals than the overlying aquifers and could be more susceptible to contamination from land-surface sources in westem Long Island than in other areas.

\section{REFERENCES CITED}

American Public Health Association, 1976, Standard methods for the examination of water and waste water, 14th ed.: Washington, D.C., American Public Health Association, 543 p.

Burr, W.H., Hering, Rudolph, and Freeman, J.R., 1904, Report of the commission on additional water supply for the City of New York: New York, Martin B. Brown, $980 \mathrm{p}$.

Buxton, H.T., Soren, Julian, Posner, Alex, and Shernoff, P.K, 1981, Reconnaissance of the ground-water resources of Kings and Queens Counties, New York: U.S. Geological Survey Open-File Report 81-1186, 59 p.

Cohen, Philip, Franke, OL., and Foxworthy, B.L., 1968, An atlas of Long Island's water resources: New York State Water Resources Commișion Bulletin 62, 117 p.

deLaguna, Wallace, 1948, Geologic correlation of logs of wells in Kings County, New York: New York State Water Power and Control Commission Bulletin GW-17, 35 p.

1964, Chemical quality of water, Brookhaven National Laboratory and vicinity, Suffolk County, New York: U.S. Geological Survey Bulletin 1156-D, $73 \mathrm{p}$.

Franke, O.L., and Cohen, Philip, 1972, Regional rates of ground-water movement on Long Island, New York, in Geological Survey Research 1972, in U.S. Geological Survey Professional Paper 800-C, p. C271-277.

Franke, O.L., and McClymonds, N.E., 1972, Summary of the hydrologic situation on Long Island, New York, as a guide to water-management alternatives: U.S. Geological Survey Professional Paper 627-F, 59 p.

Fuller, M.L., 1914, The geology of Long Island, New York: U.S. Geological Survey Professional Paper 82, $231 \mathrm{p}$.

Hem, J.D., 1970, Study and interpretation of the chemical characteristics of natural water. U.S. Geological Survey Water-Supply Paper 1473, 363 p.

Jackson, D.D., 1905, The normal distribution of chlorine in the natural waters of New York and New England: U.S. Geological Survey Water-Supply and Irrigation Paper 144, 31 p.

Jacob, C.E., 1945, The water table in westem and central parts of Long Island, New York: New York State Water Power and Control Commission Bulletin GW$12,24 \mathrm{p}$.

Johnson, A.H., and Waterman, W.G., 1952, Withdrawal of ground water on Long Island, New York: New York State Water Power and Control Commission Bulletin GW-28, 13 p.

Kimmel, GE., 1972, Nitrogen content of ground water in Kings County, Long Island, New York, in Geological Survey Research 1972, U.S. Geological Survey Professional Paper 800-D, p. D199-D203.

Koszalka, EJ., 1975, The water table on Long Island, New York, in March 1974: Suffolk County Water Authority, Long Island Water Resources Bulletin. 5, 7 p.

Leggette, R.M., and Brashears, M.L., Jr., 1938, Ground water for air-conditioning on Long Island, New York, in Transactions of the American Geophysical Union: 19th Annual Meeting, pt. 1, p. 412-418. 
Lusczynski, NJ., 1952, The recovery of ground-water levels in Brooklyn, New York, from 1947 to 1950: U.S. Geological Survey Circular 167, 29 p.

Lusczynski, NJ., and Johnson, A.W., 1951, The water table in Long Island, New York, in January 1951: New York State Water Power and Control Commission Bulletin GW-27, 28 p.

Lusczynski, NJ., and Swarzenski, W.V., 1966, Saltwater encroachment in southem Nassau and southeastem Queens Counties, Long Island, New York: U.S. Geological Survey Water-Supply Paper 1613-F, $76 \mathrm{p}$.

McClymonds, N.E., and Franke, O.L., 1972, Watertransmitting properties of aquifers on Long Island, New York: U.S. Geological Survey Professional Paper 627-E, 24 p.

Miller, J.F., and Frederick, R.H., 1969, The precipitation regime of Long Island, N.Y.: U.S. Geological Survey Professional Paper 627-A, 21 p.

New York City Department of Environmental Protection, 1981, Annual report of Bureau of Water Supply, 1981: New York City Department of Environmental Protection, Bureau of Water Supply, $126 \mathrm{p}$.

1979. Areawide waste treatment management planning program: New York City Department of Environmental Protection, Section 208, final report, $124 \mathrm{p}$.

New York City Department of Health, 1984, Jamaica Water Supply Company well sampling and well field survey, 1983: New York City Department of Health summary report, $18 \mathrm{p}$.

New York City Department of Water Supply, Gas and Electricity, 1962, Annual report of the Bureau of Water Supply for 1961: New York City Department of Water Supply, Gas and Electricity, Bureau of Water Supply, 135 p.

1948, Annual report of the Chief Engineer for 1947: New York City Department of Water Supply, Gas and Electricity, Bureau of Water Supply, $100 \mathrm{p}$.

New York City Environmental Protection Administration, 1971, Annual report of Bureau of Water Supply, 1970: New York City Environmental Protection Administration, Department of Water Resources, Bureau of Water Supply, 109 p.

New York State Department of Health, 1977, New York State Water Supervision Program: New York State Department of Health, Division of Sanitary Engineering, Bureau of Water Supply, State Sanitary Code, Subpart 5-1 Public Water Supplies, p. $1-46$.

Pearson, FJ., Jr., and Fisher, D.W., 1971, Chemical composition of atmospheric precipitation in North- eastem United States: U.S. Geological Survey Water-Supply Paper 1535-P, 23 p.

Perlmutter, N.M., and Soren, Julian, 1962, Effects of major water-table changes in Kings and Queens Counties, New York City, in Geological Survey Research 1962: U.S. Geological Survey Professional Paper 450-E, p. E136-E139.

Smolensky, D.A., Buxton, H.T., and Shernoff, P.K. 1989, Hydrogeologic framework of Long Island, New York: U.S. Geological Survey Hydrologic Atlas HA-709, 3 sheets, scale 1:250,000.

Soren, Julian, 1971, ground-water and geohydrologic conditions in Queens County, Long Island, New York: U.S. Geological Survey Water-Supply Paper 2001-A, 39 p.

1976, Basement flooding and foundation damage from water-table rise in the east New York sectionof Brooklyn, Long Island, New York: U.S. Geological Survey Water Resources Investigations 76-95, $14 \mathrm{p}$.

1978, Subsurface geology and paleogeography of Queens County, Long Island, New York: U.S. Geological Survey Water Resources Investigations Open-File Report 77-34, 17 p.

Spear, WE., 1912, Long Island sources_an additional supply of water for the City of New York: New York City Board of Water Supply, 708 p.

Suter, Russell, 1937, Engineering report on the water supplies of Long Island: New York State Water Power and Control Commission Bulletin GW-2, 64 p.

Suter, Russell, de Laguna, Wallace, and Perlmutter, N.M., 1949, Mapping of geologic formations and aquifers of Long Island, New York: New York State Water Power and Control Commission Bulletin GW-18, 212 p.

Thompson, D.G., and Leggette, R.M., 1936, Withdrawal of ground water on Long Island, New York: New York State Water Power and Control Commission Bulletin GW-1, 28 p.

U.S. Geological Survey, 1965, Water resources data for New York, Part 2, water-quality records: U.S. Geological Survey Open-File Report, 112 p. (issued annually.)

Veatch, A.C., Slichter, C.S. Bowman, Isaiah, Crosby, W.O., and Horton, R.E., 1906, Underground water resources of Long Island, New York: U.S. Geological Survey Professional Paper 44, 394 p.

Vecchioli, John, Bennett, G.D., Pearson, FJ., Jr., and Cerrillo, LAA., 1974, Geohydrology of the artificialrecharge site at Bay Park, Long Island, New York: U.S. Geological Survey Professional Paper 751-C, 29 p.

Weast, R.C. (ed.), 1981, CRC handbook of chemistry and physics, 62d Edition: Boca Raton, Fla., CRC Press Inc., chapters A-F. 


\section{TABLES OF WELL AND CHEMICAL DATA}

Table 7. Wells and test borings plotted on plate 2 that occupy a multiple-well site $\ldots \ldots \ldots \ldots . \quad 57$

Table 8. Observation wells whose records were used to produce maps of water-table

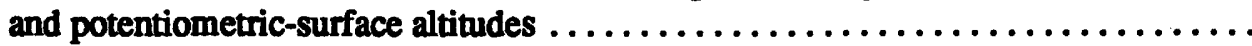

Table 9. Hydrogeologic units penetrated by wells and test holes in Kings, Queens, Nassau, Bronx, New York, and Richmond Counties.

Table 10. Selected chemical analyses of ground-water samples from observation wells in Kings, Queens, and Nassau Counties . . . . . . . . . . . . . . . . . . . .

Table 11. Selected chemical analyses of ground water sampled from public- supply wells in Kings, Queens, and westem Nassau Counties1 ..................... 
Table 7. Wells and test borings plotted on plate 2 that occupy a multiple well site.

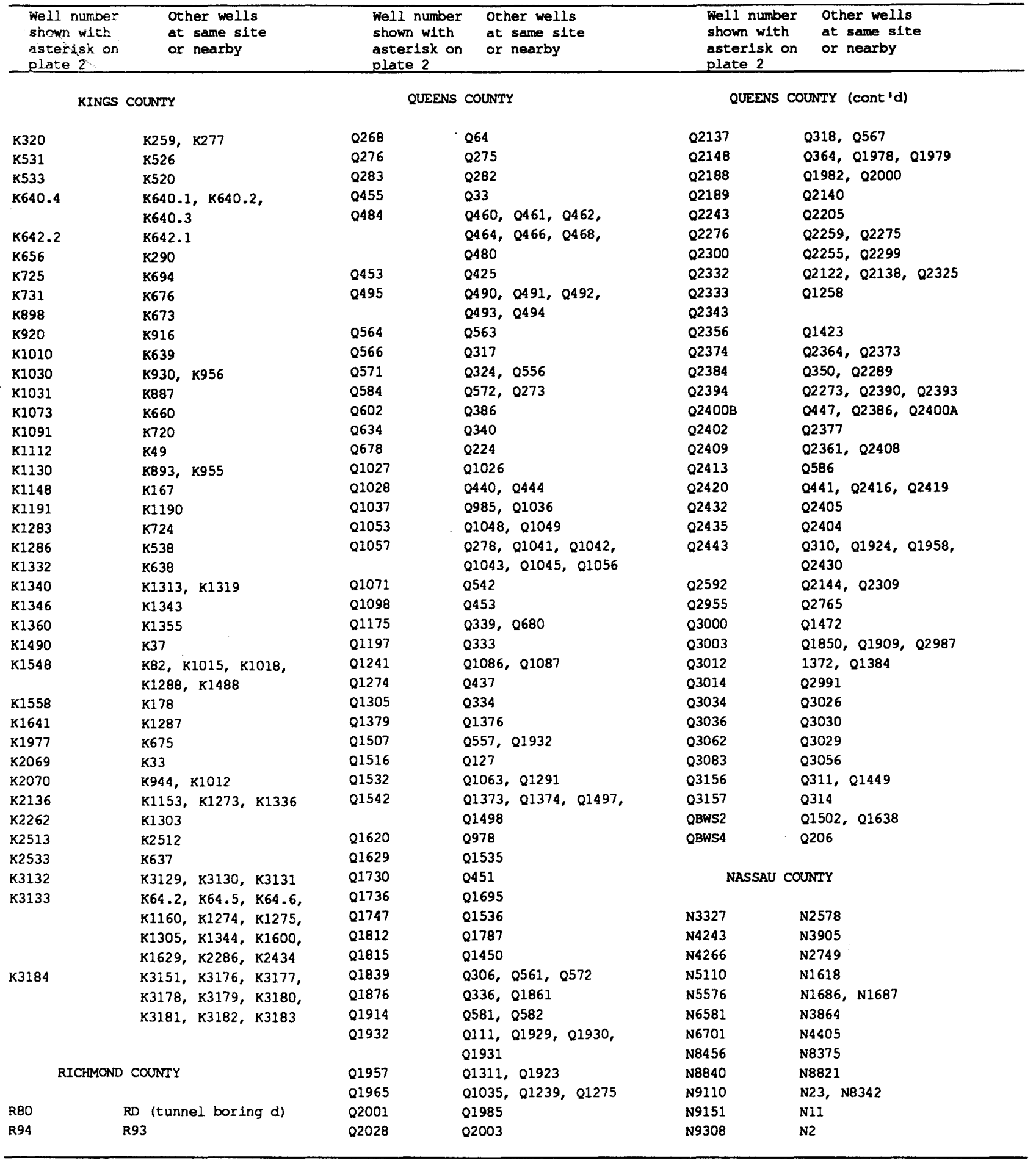


Table 8.- -bservation wells whose records were used to produce maps of water-table and potentionetrlc-surface altitudes

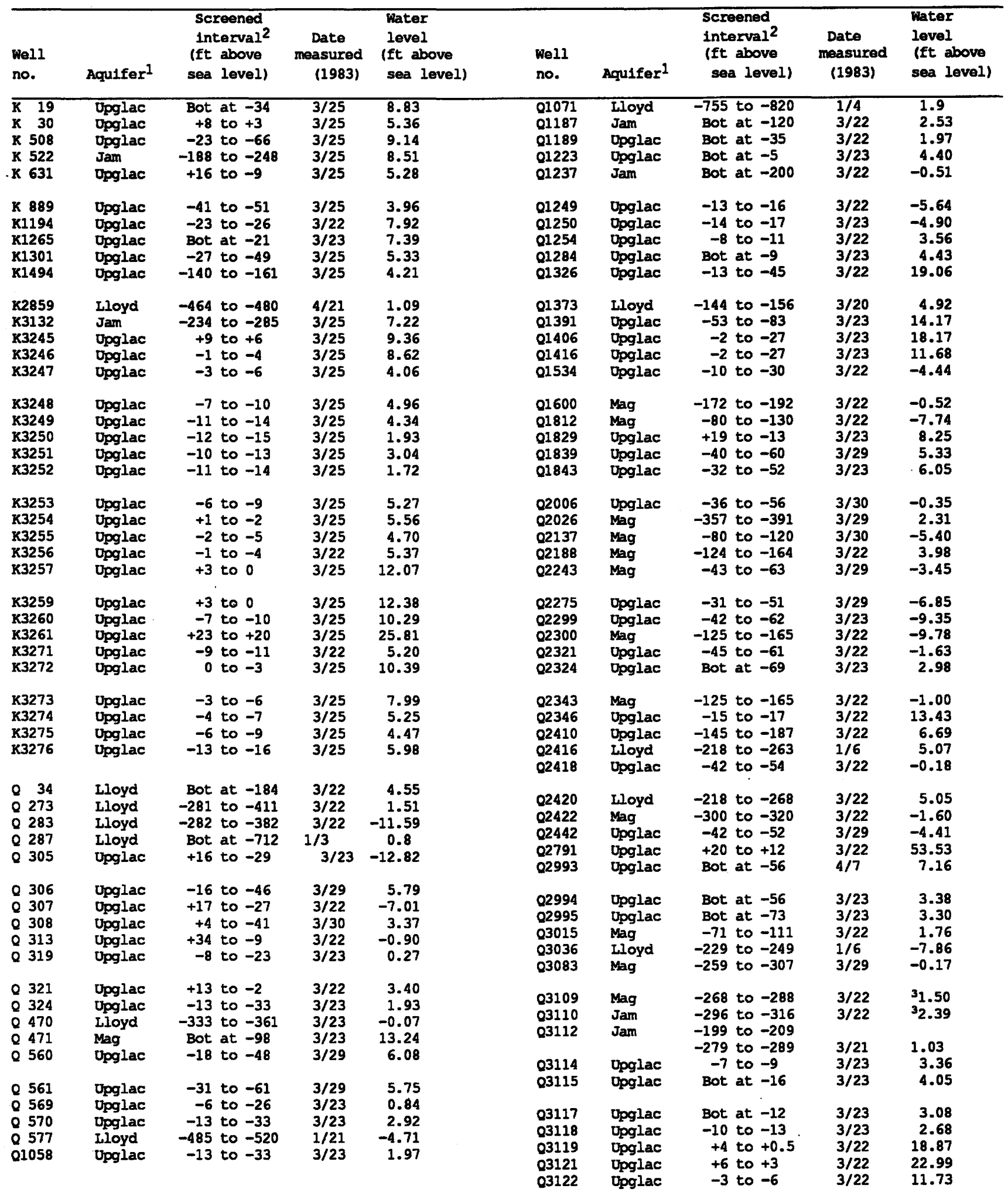


Table 8.- - Observation wells whose records were used to produce maps of water-table and potentiometric-surface altitudes (continued)

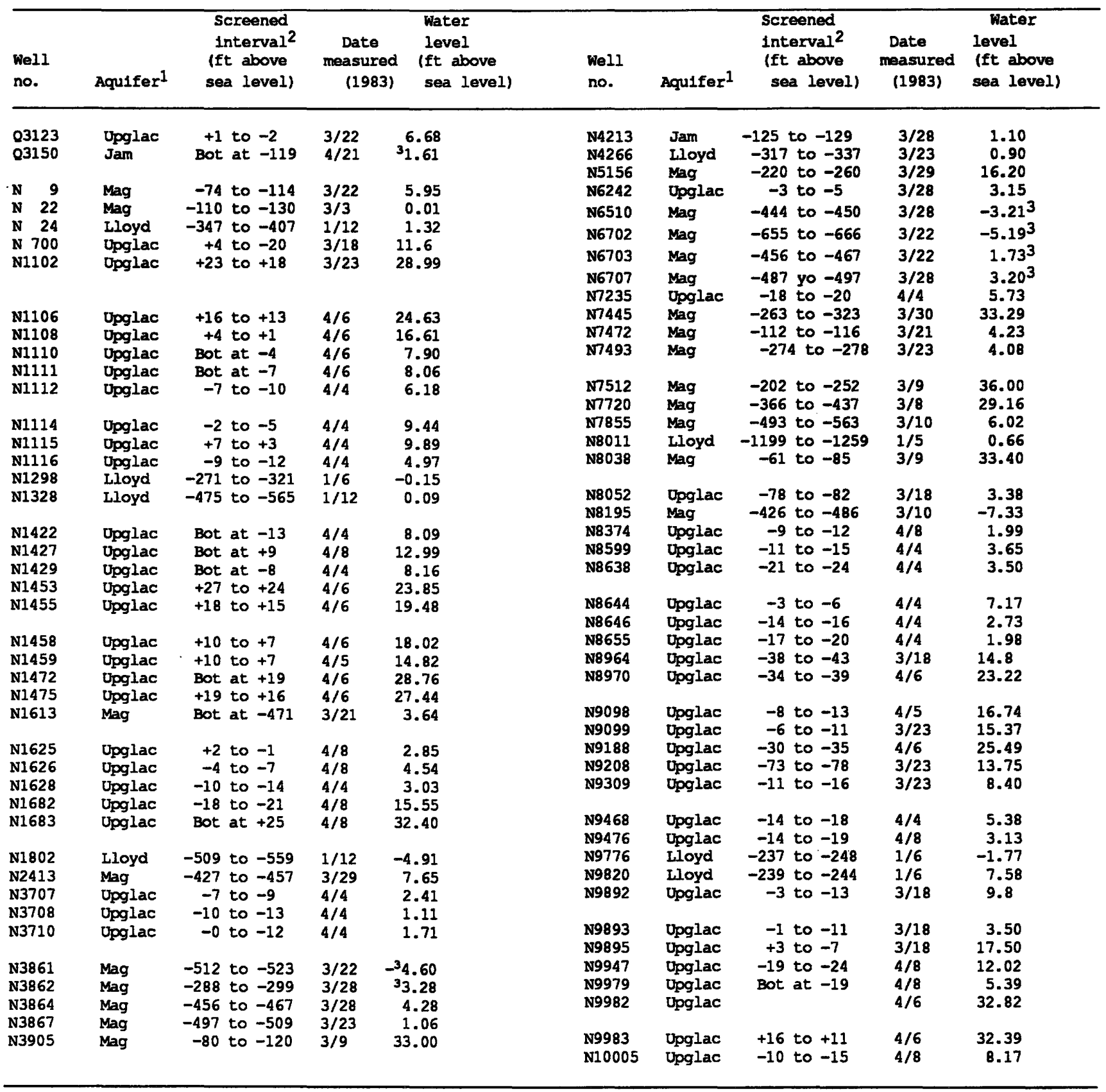

\footnotetext{
1 Upglac $=$ Upper glacial

Jam = Jameco Gravel

Mag = Magothy

2 Bot $=$ Bottom

3 Freshwater equivalent head listed in table 5, p. 36.
} 
Table 9.--Hydrogeologic units penetrated by wells and test holes in Kings, Queens, Nassau, Bronx, New York, and Richmond Counties.

[Well locations are shown on pl. 1]

\begin{tabular}{|c|c|c|c|c|c|c|c|c|c|c|c|c|c|}
\hline \multirow{3}{*}{\multicolumn{2}{|c|}{$\begin{array}{l}\text { Well- } \\
\text { identi- } \\
\text { fication } \\
\text { number }\end{array}$}} & \multirow[b]{3}{*}{ Lat. } & \multirow[b]{3}{*}{ Long. } & \multirow{2}{*}{\multicolumn{2}{|c|}{$\begin{array}{l}\text { Altitude of } \\
\text { well, in feet } \\
\text { above or } \\
\text { below (-) sea } \\
\text { level }\end{array}$}} & \multicolumn{6}{|c|}{$\begin{array}{l}\text { Hydrogeologic unit penetrated and altitude of } \\
\text { unit surface, in feet above or below }(-) \text { sea level } 1\end{array}$} & \multirow{3}{*}{$\begin{array}{l}\text { Iocated } \\
\text { near well }\end{array}$} & \multirow[b]{3}{*}{ Remarks ${ }^{2}$} \\
\hline & & & & & & \multirow{2}{*}{$\begin{array}{l}\text { Gardiners } \\
\text { Clay }\end{array}$} & \multirow{2}{*}{$\begin{array}{l}\text { Jameco } \\
\text { Gravel }\end{array}$} & \multirow{2}{*}{$\begin{array}{l}\text { Magothy } \\
\text { aquifer }\end{array}$} & \multirow{2}{*}{$\begin{array}{l}\text { Raritan } \\
\text { confining } \\
\text { unit }\end{array}$} & \multirow{2}{*}{$\begin{array}{l}\text { Lloyd } \\
\text { aquifer }\end{array}$} & \multirow[b]{2}{*}{ Bedrock } & & \\
\hline & & & & Top & Bottom & & & & & & & & \\
\hline $\begin{array}{l}\mathbf{B} \\
\mathbf{B} \\
\mathbf{B} \\
\mathbf{B} \\
\mathbf{B}\end{array}$ & $\begin{array}{r}1 \\
2 \\
3 \\
4 \\
39\end{array}$ & $\begin{array}{l}404826 \\
404817 \\
404852 \\
405130 \\
404831\end{array}$ & $\begin{array}{l}735000 \\
734958 \\
734909 \\
734616 \\
735005\end{array}$ & $\begin{array}{r}2 \\
0 \\
9 \\
10 \\
2\end{array}$ & -90 & & & & & & $\begin{array}{r}-63 \\
-98 \\
-50 \\
-2 \\
-63\end{array}$ & & \\
\hline $\begin{array}{l}\mathbf{B} \\
\mathbf{B} \\
\mathbf{M} \\
\mathbf{M} \\
\mathbf{M}\end{array}$ & $\begin{array}{r}59 \\
69 \\
41 \\
114 \\
160\end{array}$ & $\begin{array}{l}404820 \\
404845 \\
404240 \\
404236 \\
404705\end{array}$ & $\begin{array}{l}735249 \\
735210 \\
740029 \\
740037 \\
735635\end{array}$ & $\begin{array}{r}8 \\
0 \\
30 \\
30 \\
3\end{array}$ & $\begin{array}{r}-80 \\
-76 \\
-46 \\
-47 \\
-146\end{array}$ & & & & & & $\begin{array}{r}-70 \\
-71 \\
-46 \\
-47 \\
-139\end{array}$ & & \\
\hline $\begin{array}{l}\mathbf{M} \\
\mathbf{R} \\
\mathbf{R} \\
\mathbf{R} \\
\mathbf{R}\end{array}$ & $\begin{array}{r}161 \\
\text { A } \\
\text { B } \\
\text { C } \\
\text { D }\end{array}$ & $\begin{array}{l}404432 \\
403614 \\
403609 \\
403834 \\
403831\end{array}$ & $\begin{array}{l}735915 \\
740310 \\
740326 \\
740413 \\
740440\end{array}$ & $\begin{array}{r}30 \\
0 \\
90\end{array}$ & $\begin{array}{r}7 \\
-210 \\
-216\end{array}$ & $\begin{array}{r}-124 \\
-99\end{array}$ & -170 & & & & $\begin{array}{r}16 \\
-190 \\
-163 \\
-115 \\
100\end{array}$ & R80 & $\begin{array}{l}\text { Bridge boring } \\
\text { Bridge boring } \\
\text { Tunnel boring } \\
\text { Tunnel boring }\end{array}$ \\
\hline $\begin{array}{l}\mathbf{R} \\
\mathbf{R} \\
\mathbf{R} \\
\mathbf{R} \\
\mathbf{R}\end{array}$ & $\begin{array}{l}7 \\
14 \\
18 \\
22 \\
65\end{array}$ & $\begin{array}{l}403753 \\
403734 \\
403659 \\
403700 \\
403506\end{array}$ & $\begin{array}{l}740437 \\
740445 \\
740416 \\
740358 \\
740538\end{array}$ & $\begin{array}{l}10 \\
25 \\
45 \\
15 \\
10\end{array}$ & $\begin{array}{r}-40 \\
-18 \\
-97 \\
-162 \\
-77\end{array}$ & & & & -75 & & -162 & & \\
\hline $\begin{array}{l}\mathbf{R} \\
\mathbf{R} \\
\mathbf{R} \\
\mathbf{R} \\
\mathbf{R}\end{array}$ & $\begin{array}{l}66 \\
73 \\
79 \\
80 \\
81\end{array}$ & $\begin{array}{l}403529 \\
403730 \\
403815 \\
403830 \\
403831\end{array}$ & $\begin{array}{l}740518 \\
740449 \\
740519 \\
740441 \\
740433\end{array}$ & $\begin{array}{r}12 \\
50 \\
120 \\
110 \\
40\end{array}$ & $\begin{array}{r}-87 \\
-30 \\
76 \\
73 \\
-9\end{array}$ & & & & -84 & & $\begin{array}{r}-30 \\
110 \\
106 \\
6\end{array}$ & & \\
\hline $\begin{array}{l}\mathbf{R} \\
\mathbf{R} \\
\mathbf{R} \\
\mathbf{R} \\
\mathbf{R}\end{array}$ & $\begin{array}{l}82 \\
89 \\
91 \\
93 \\
94\end{array}$ & $\begin{array}{l}403443 \\
403659 \\
403652 \\
403646 \\
403643\end{array}$ & $\begin{array}{l}740316 \\
740409 \\
740404 \\
740359 \\
740357\end{array}$ & $\begin{array}{r}5 \\
25 \\
25 \\
25 \\
25\end{array}$ & $\begin{array}{r}-1000 \\
-11 \\
-15 \\
-27 \\
-34\end{array}$ & & & NR & NRR & NR & -450 & R94 & \\
\hline
\end{tabular}


Table 9.--Hydrogeologic units penetrated by wells and test holes in Kings, Queens, Nassau, Bronx, New York, and Richmond Counties (continued)

[Well locations are shown on pl. 1]

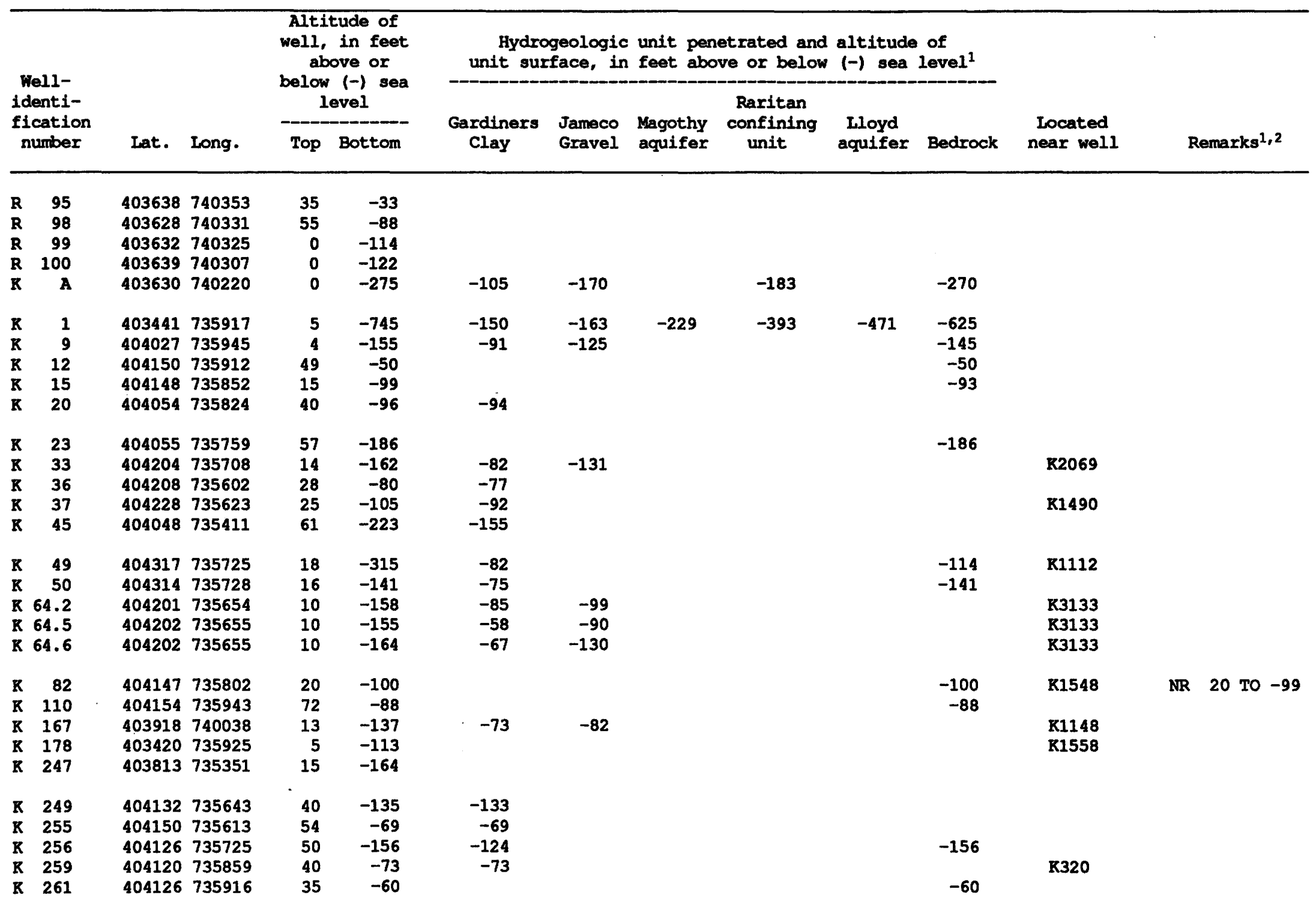

$1_{\text {PRES }}$ - Unit present but surface altitude not discernible.

NR - No record; no record near altitudes indicated under remarks.

${ }^{2}$ Veatch - Well number from numbering system employed in Veatch and others, 1906. 
Table 9.--Hydrogeologic units penetrated by wells and test holes in Kings, Queens, Nassau, Bronx, New York, and Richmond Counties (continued)

Well locations are shown on pl. 1]

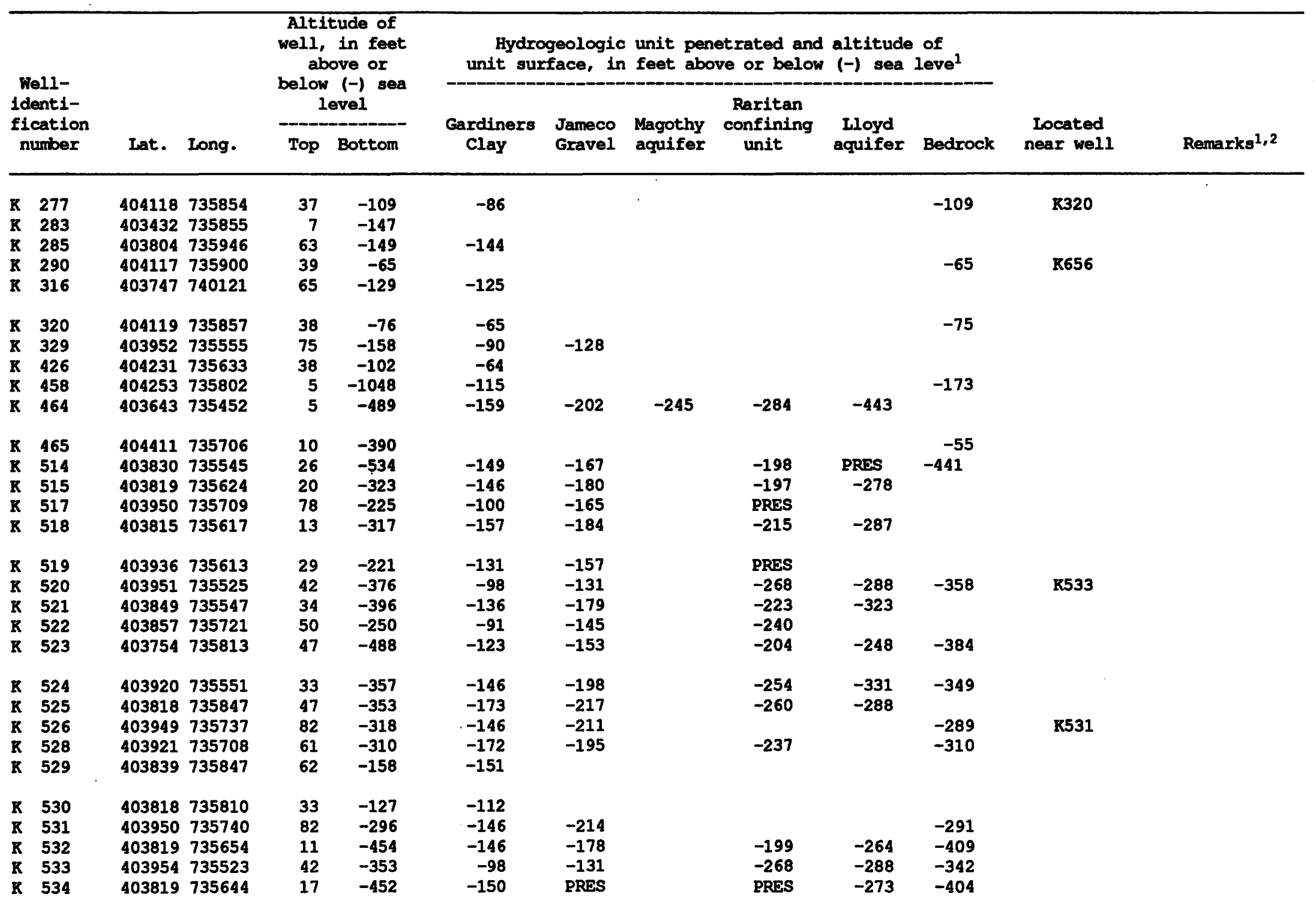


Table 9.--Hydrogeologic units penetrated by wells and test holes in Kings, Queens, Nassau, Bronx, New York, and Richmond Counties (continued)

[Well locations are shown on pl. 1]

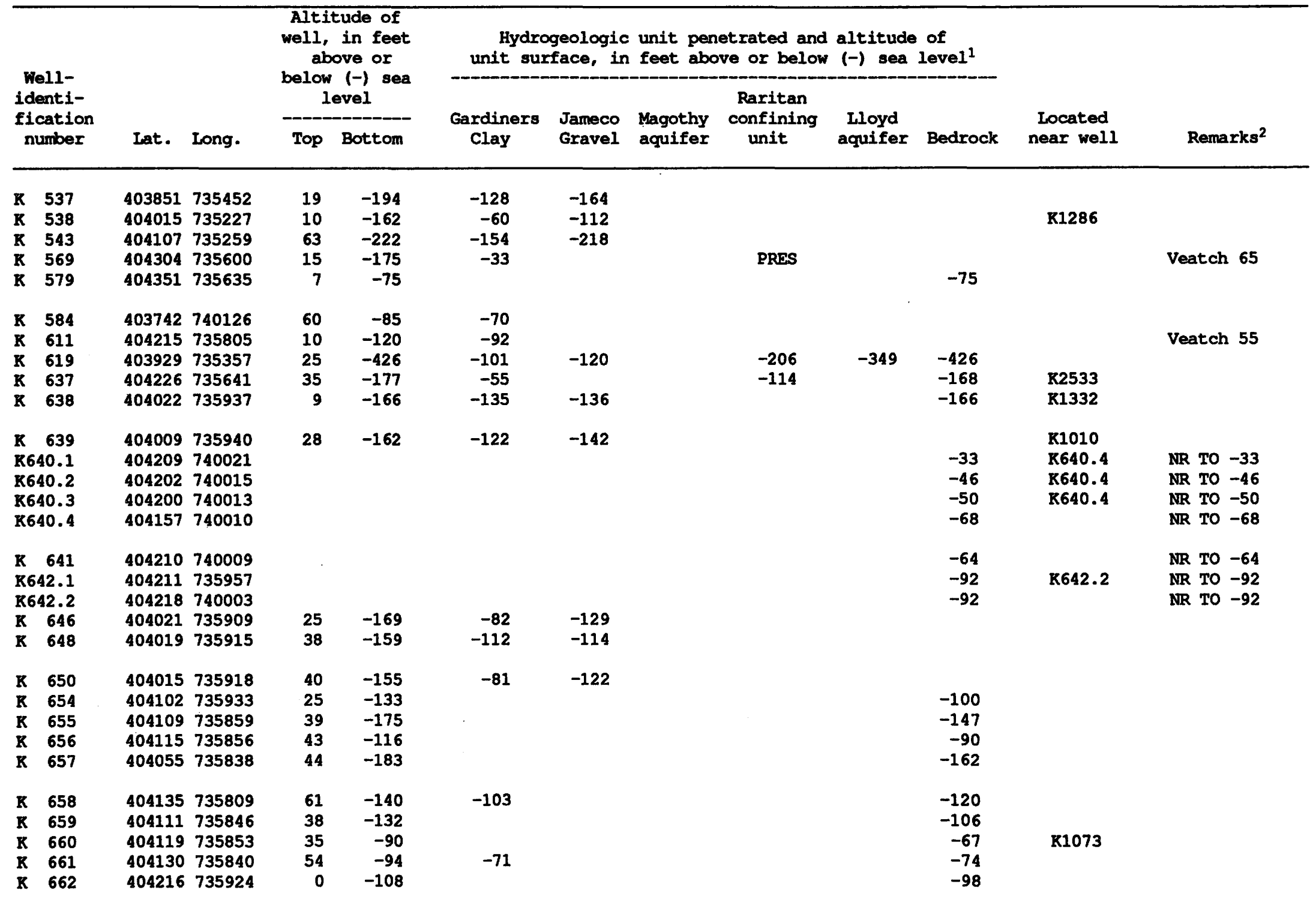

IPRES - Unit present but surface altitude not discernible.

NR - No record; no record near altitudes indicated under remarks.

${ }^{2}$ Veatch - Well number from numbering system employed in Veatch and others, 1906. 
Table 9.--Hydrogeologic units penetrated by wells and test holes in Kings, Queens, Nassau, Bronx, New York, and Richmond Counties (continued)

Well locations are shown on pl. 1]

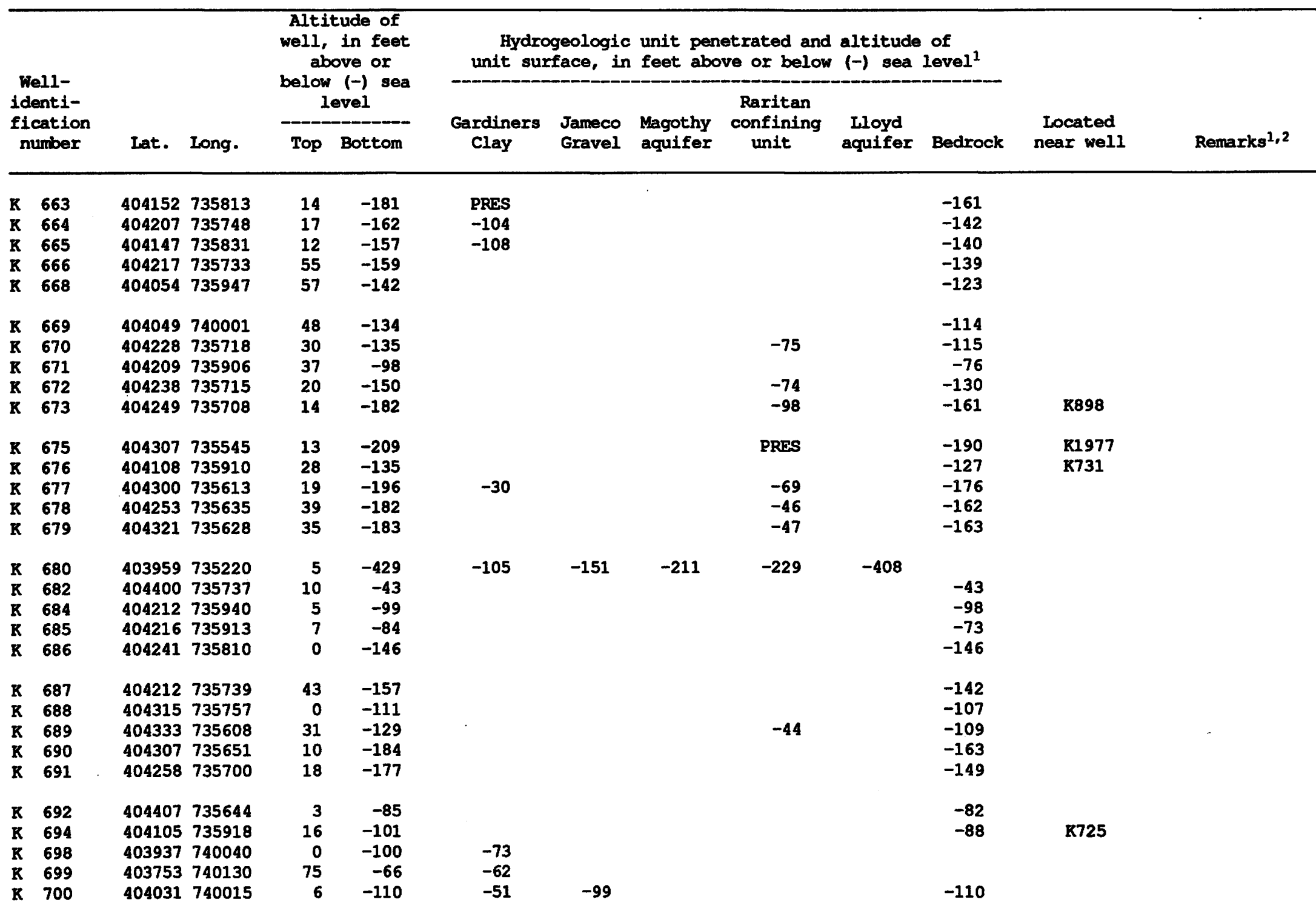


Table 9.-Hydrogeologic units penetrated by wells and test holes in Kings, Queens, Nassau, Bronx, New York, and Richmond Counties (continued)

[Well locations are shown on pl. 1]

\begin{tabular}{|c|c|c|c|c|c|c|c|c|c|c|c|c|c|c|}
\hline \multirow{3}{*}{\multicolumn{2}{|c|}{$\begin{array}{l}\text { Well- } \\
\text { Identi- } \\
\text { fication } \\
\text { number }\end{array}$}} & \multirow[b]{3}{*}{ Lat. } & \multirow[b]{3}{*}{ Long. } & \multirow{2}{*}{\multicolumn{2}{|c|}{$\begin{array}{l}\text { Altitude of } \\
\text { well, in feet } \\
\text { above or } \\
\text { below ( }- \text { ) sea } \\
\text { level }\end{array}$}} & \multicolumn{6}{|c|}{$\begin{array}{l}\text { Hydrogeologic unit penetrated and altitude of } \\
\text { unit surface, in feet above or below }(-) \text { sea level } 1\end{array}$} & \multirow[b]{3}{*}{$\begin{array}{l}\text { Located } \\
\text { near well }\end{array}$} & \multirow{3}{*}{\multicolumn{2}{|c|}{ Remarks $^{1}$}} \\
\hline & & & & & & \multirow[b]{2}{*}{$\begin{array}{l}\text { Gardiners } \\
\text { Clay }\end{array}$} & \multirow[b]{2}{*}{$\begin{array}{l}\text { Jameco } \\
\text { Gravel }\end{array}$} & \multirow[b]{2}{*}{$\begin{array}{l}\text { Magothy } \\
\text { aquifer }\end{array}$} & \multirow{2}{*}{$\begin{array}{l}\text { Raritan } \\
\text { confining } \\
\text { unit }\end{array}$} & \multirow[b]{2}{*}{$\begin{array}{l}\text { Lloyd } \\
\text { aquifer }\end{array}$} & \multirow[b]{2}{*}{ Bedrock } & & & \\
\hline & & & & Top & Bottom & & & & & & & & & \\
\hline $\begin{array}{l}\mathbf{K} \\
\mathbf{R} \\
\mathbf{K} \\
\mathbf{K} \\
\mathbf{K}\end{array}$ & $\begin{array}{l}701 \\
702 \\
703 \\
704 \\
705\end{array}$ & $\begin{array}{l}404006 \\
404058 \\
404041 \\
404035 \\
404044\end{array}$ & $\begin{array}{l}740027 \\
735936 \\
740014 \\
740030 \\
740100\end{array}$ & $\begin{array}{r}0 \\
28 \\
16 \\
7 \\
10\end{array}$ & $\begin{array}{r}-83 \\
-112 \\
-122 \\
-123 \\
-141\end{array}$ & $\begin{array}{l}-50 \\
-93 \\
-51\end{array}$ & $\begin{array}{l}-104 \\
-121\end{array}$ & & & & $\begin{array}{r}-88 \\
-125 \\
-110\end{array}$ & & & \\
\hline $\begin{array}{l}\mathbf{R} \\
\mathbf{K} \\
\mathbf{R} \\
\mathbf{R} \\
\mathbf{K}\end{array}$ & $\begin{array}{l}708 \\
709 \\
710 \\
711 \\
715\end{array}$ & $\begin{array}{l}404132 \\
404156 \\
404401 \\
404359 \\
404233\end{array}$ & $\begin{array}{l}740008 \\
735909 \\
735719 \\
735628 \\
735644\end{array}$ & $\begin{array}{r}6 \\
56 \\
13 \\
0 \\
36\end{array}$ & $\begin{array}{r}-114 \\
-83 \\
-41 \\
-74 \\
-84\end{array}$ & -49 & & & & & $\begin{array}{l}-82 \\
-62 \\
-28 \\
-74\end{array}$ & & & \\
\hline $\begin{array}{l}\mathbf{R} \\
\mathbf{K} \\
\mathbf{R} \\
\mathbf{K} \\
\mathbf{K}\end{array}$ & $\begin{array}{l}725 \\
728 \\
729 \\
730 \\
731\end{array}$ & $\begin{array}{l}404104 \\
404147 \\
404141 \\
404136 \\
404107\end{array}$ & $\begin{array}{l}735922 \\
735906 \\
735826 \\
735902 \\
735914\end{array}$ & $\begin{array}{l}14 \\
36 \\
45 \\
36 \\
23\end{array}$ & $\begin{array}{r}-101 \\
-96 \\
-130 \\
-98 \\
-187\end{array}$ & & & & & & $\begin{array}{r}-80 \\
-79 \\
-108 \\
-68 \\
-160\end{array}$ & & & \\
\hline $\begin{array}{l}\mathbf{K} \\
\mathbf{K} \\
\mathbf{K} \\
\mathbf{K} \\
\mathbf{K}\end{array}$ & $\begin{array}{l}887 \\
893 \\
894 \\
898 \\
910\end{array}$ & $\begin{array}{l}404201 \\
404225 \\
404215 \\
404248 \\
404010\end{array}$ & $\begin{array}{l}735556 \\
735607 \\
735555 \\
735709 \\
735444\end{array}$ & $\begin{array}{l}49 \\
20 \\
30 \\
-3 \\
45\end{array}$ & $\begin{array}{r}-76 \\
-98 \\
-252 \\
-71 \\
-137\end{array}$ & $\begin{array}{r}-46 \\
-61 \\
-57 \\
-126\end{array}$ & & & -148 & & & $\begin{array}{l}\text { R1031 } \\
\text { K1130 }\end{array}$ & & \\
\hline $\begin{array}{l}\mathbf{K} \\
\mathbf{K} \\
\mathbf{K} \\
\mathbf{K} \\
\mathbf{K}\end{array}$ & $\begin{array}{l}916 \\
917 \\
920 \\
921 \\
922\end{array}$ & $\begin{array}{l}404019 \\
404028 \\
404020 \\
404038 \\
403919\end{array}$ & $\begin{array}{l}735921 \\
735906 \\
735922 \\
735741 \\
740027\end{array}$ & $\begin{array}{r}13 \\
10 \\
13 \\
118 \\
12\end{array}$ & $\begin{array}{r}-149 \\
-96 \\
-151 \\
-213 \\
-138\end{array}$ & $\begin{array}{c}-118 \\
-117 \\
\text { NR } \\
-87\end{array}$ & $\begin{array}{l}-122 \\
\text { NR } \\
-102\end{array}$ & & & & -213 & K920 & NR & 118 To -212 \\
\hline
\end{tabular}

${ }^{1}$ PRES - Unit present but surface altitude not discernible.

NR - No record; no record near altitudes indicated under remarks. 
Table 9. - Hydrogeologic units penetrated by wells and test holes in Kings, Queens, Nassau, Bronx, New York, and Richmond Counties (continued)

[Well locations are shown on pl. 1]

\begin{tabular}{|c|c|c|c|c|c|c|c|c|c|c|c|c|}
\hline \multirow{3}{*}{$\begin{array}{l}\text { Well- } \\
\text { identi- } \\
\text { fication } \\
\text { number }\end{array}$} & \multirow[b]{3}{*}{ Iat. } & \multirow[b]{3}{*}{ Long. } & \multirow{2}{*}{\multicolumn{2}{|c|}{$\begin{array}{c}\text { Altitude of } \\
\text { well, in feet } \\
\text { above or } \\
\text { below (-) sea } \\
\text { level }\end{array}$}} & \multicolumn{6}{|c|}{$\begin{array}{l}\text { Hydrogeologic unit penetrated and altitude of } \\
\text { unit surface, in feet above or below }(-) \text { sea level }{ }^{1}\end{array}$} & \multirow[b]{3}{*}{$\begin{array}{l}\text { Located } \\
\text { near well }\end{array}$} & \multirow[b]{3}{*}{ Remarks 1,2} \\
\hline & & & & & \multirow[b]{2}{*}{$\begin{array}{l}\text { Gardiners } \\
\text { Clay }\end{array}$} & \multirow[b]{2}{*}{$\begin{array}{l}\text { Jameco } \\
\text { Gravel }\end{array}$} & \multirow[b]{2}{*}{$\begin{array}{l}\text { Magothy } \\
\text { aquifer }\end{array}$} & \multirow{2}{*}{$\begin{array}{l}\text { Raritan } \\
\text { confining } \\
\text { unit }\end{array}$} & \multirow[b]{2}{*}{$\begin{array}{l}\text { Lloyd } \\
\text { aquifer }\end{array}$} & \multirow[b]{2}{*}{ Bedrock } & & \\
\hline & & & Top & Bottom & & & & & & & & \\
\hline $\begin{array}{ll}\mathrm{K} & 930 \\
\mathrm{~K} & 944 \\
\mathrm{~K} & 952 \\
\mathrm{~K} & 955 \\
\mathrm{~K} & 956\end{array}$ & $\begin{array}{l}404037 \\
403912 \\
404146 \\
404225 \\
404037\end{array}$ & $\begin{array}{l}735904 \\
740052 \\
735602 \\
735610 \\
735905\end{array}$ & $\begin{array}{l}20 \\
18 \\
67 \\
18 \\
22\end{array}$ & $\begin{array}{r}-160 \\
-139 \\
-55 \\
-54 \\
-160\end{array}$ & $\begin{array}{r}-123 \\
-84 \\
-55 \\
-47 \\
-96\end{array}$ & $\begin{array}{l}-129 \\
-102 \\
-130\end{array}$ & & & & -160 & $\begin{array}{l}\text { R1030 } \\
\text { K2070 } \\
\text { K1130 } \\
\text { K1030 }\end{array}$ & \\
\hline $\begin{array}{ll}\text { R } & 1010 \\
\text { R } & 1012 \\
\text { R } & 1015 \\
\text { R } & 1018 \\
\text { K } & 1020\end{array}$ & $\begin{array}{l}404009 \\
403912 \\
404146 \\
404146 \\
403420\end{array}$ & $\begin{array}{l}735941 \\
740052 \\
735807 \\
735807 \\
735942\end{array}$ & $\begin{array}{r}20 \\
16 \\
20 \\
18 \\
5\end{array}$ & $\begin{array}{r}-161 \\
-159 \\
-72 \\
-98 \\
-108\end{array}$ & $\begin{array}{r}\text { PRES } \\
-100 \\
-72 \\
-44\end{array}$ & $\begin{array}{l}-136 \\
-124\end{array}$ & & & & & $\begin{array}{l}\text { K2070 } \\
\text { K1548 } \\
\text { K1548 }\end{array}$ & \\
\hline $\begin{array}{ll}\text { K } & 1056 \\
K & 1057 \\
K & 1073 \\
K & 1091 \\
\text { K } & 1112\end{array}$ & $\begin{array}{l}403452 \\
403503 \\
404117 \\
404030 \\
404314\end{array}$ & $\begin{array}{l}735248 \\
735251 \\
735848 \\
740007 \\
735723\end{array}$ & $\begin{array}{r}7 \\
13 \\
32 \\
11 \\
7\end{array}$ & $\begin{array}{r}-733 \\
-711 \\
-88 \\
-113 \\
-48\end{array}$ & -38 & $\begin{array}{l}-123 \\
-127 \\
-88\end{array}$ & $\begin{array}{l}-213 \\
-217\end{array}$ & $\begin{array}{l}-493 \\
-487\end{array}$ & $\begin{array}{l}-683 \\
-693\end{array}$ & -62 & & $\begin{array}{l}\text { Veatch } 130 \\
\text { Veatch } 131\end{array}$ \\
\hline $\begin{array}{ll}\text { K } & 1130 \\
K & 1148 \\
K & 1153 \\
\text { K } & 1160 \\
\text { K } & 1190\end{array}$ & $\begin{array}{l}404225 \\
403916 \\
404206 \\
404201 \\
404056\end{array}$ & $\begin{array}{l}735613 \\
740036 \\
735605 \\
735656 \\
740025\end{array}$ & $\begin{array}{l}18 \\
11 \\
40 \\
10 \\
10\end{array}$ & $\begin{array}{r}-71 \\
-139 \\
-61 \\
-125 \\
-55\end{array}$ & $\begin{array}{l}-63 \\
-86 \\
-61 \\
-69 \\
-54\end{array}$ & $\begin{array}{r}-95 \\
-101\end{array}$ & & & & & $\begin{array}{l}\text { K2136 } \\
\text { K3133 } \\
\text { K1191 }\end{array}$ & \\
\hline $\begin{array}{ll}\mathrm{K} & 1191 \\
\mathrm{~K} & 1192 \\
\mathrm{~K} & 1271 \\
\mathrm{~K} & 1273 \\
\mathrm{~K} & 1274\end{array}$ & $\begin{array}{l}404055 \\
404055 \\
403920 \\
404206 \\
404202\end{array}$ & $\begin{array}{l}740026 \\
740011 \\
740048 \\
735605 \\
735655\end{array}$ & $\begin{array}{r}1 \\
30 \\
5 \\
40 \\
10\end{array}$ & $\begin{array}{r}-59 \\
-82 \\
-1498 \\
-235 \\
-155\end{array}$ & $\begin{array}{l}-59 \\
-90 \\
-65 \\
-55\end{array}$ & $\begin{array}{l}-134 \\
-140\end{array}$ & & PRES & & -207 & $\begin{array}{l}\text { K2136 } \\
\text { R3133 }\end{array}$ & $\begin{array}{ll}\text { Veatch } & 5 \\
\text { Veatch } & 35 \\
\text { Veatch } & 37\end{array}$ \\
\hline
\end{tabular}

${ }^{1}$ PRES - Unit present but surface altitude not discernible.

${ }^{2}$ Veatch - Well number from numbering system employed in Veatch and others, 1906. 
Table 9.--Hydrogeologic units penetrated by wells and test holes in Kings, Queens, Nassau, Bronx, New York, and Richmond Counties (continued)

[Well locations are shown on pl. 1]

\begin{tabular}{|c|c|c|c|c|c|c|c|c|c|c|c|c|}
\hline \multirow{3}{*}{$\begin{array}{l}\text { Well- } \\
\text { identi- } \\
\text { fication } \\
\text { number }\end{array}$} & \multirow[b]{3}{*}{ Iat. } & \multirow[b]{3}{*}{ Long. } & \multirow{2}{*}{\multicolumn{2}{|c|}{$\begin{array}{l}\text { Altitude of } \\
\text { well, in feet } \\
\text { above or } \\
\text { below (-) sea } \\
\text { level }\end{array}$}} & \multicolumn{6}{|c|}{$\begin{array}{l}\text { Hydrogeologic unit penetrated and altitude of } \\
\text { unit surface, in feet above or below }(-) \text { sea level } 1\end{array}$} & \multirow{3}{*}{$\begin{array}{l}\text { Iocated } \\
\text { near well }\end{array}$} & \multirow[b]{3}{*}{ Remarks 1,2} \\
\hline & & & & & \multirow{2}{*}{$\begin{array}{l}\text { Gardiners } \\
\text { Clay }\end{array}$} & \multirow{2}{*}{$\begin{array}{l}\text { Jameco } \\
\text { Gravel }\end{array}$} & \multirow{2}{*}{$\begin{array}{l}\text { Magothy } \\
\text { aquifer }\end{array}$} & \multirow{2}{*}{$\begin{array}{l}\text { Raritan } \\
\text { confining } \\
\text { unit }\end{array}$} & \multirow{2}{*}{$\begin{array}{l}\text { Lloyd } \\
\text { aquifer }\end{array}$} & \multirow[b]{2}{*}{ Bedrock } & & \\
\hline & & & Top & Bottom & & & & & & & & \\
\hline $\begin{array}{ll}\mathrm{K} & 1275 \\
\mathrm{~K} & 1283 \\
\mathrm{~K} & 1286 \\
\mathrm{~K} & 1287 \\
\mathrm{~K} & 1288\end{array}$ & $\begin{array}{l}404202 \\
404239 \\
404012 \\
403903 \\
404143\end{array}$ & $\begin{array}{l}735655 \\
735632 \\
735229 \\
735734 \\
735809\end{array}$ & $\begin{array}{l}10 \\
45 \\
10 \\
50 \\
30\end{array}$ & $\begin{array}{r}-165 \\
-195 \\
-154 \\
-111 \\
-78\end{array}$ & $\begin{array}{l}\text { PRES } \\
-60 \\
-78\end{array}$ & $\begin{array}{l}-129 \\
-108\end{array}$ & & PRES & & & $\begin{array}{l}\text { K3133 } \\
\text { K1641 } \\
\text { K1548 }\end{array}$ & $\begin{array}{ll}\text { Veatch } & 38 \\
\text { Veatch } & 62 \\
\text { Veatch } & 135\end{array}$ \\
\hline $\begin{array}{ll}R & 1303 \\
R & 1305 \\
R & 1309 \\
R & 1313 \\
R & 1319\end{array}$ & $\begin{array}{l}404256 \\
404200 \\
403940 \\
404146 \\
404145\end{array}$ & $\begin{array}{l}735734 \\
735701 \\
735458 \\
735756 \\
735757\end{array}$ & $\begin{array}{l}16 \\
10 \\
30 \\
31 \\
31\end{array}$ & $\begin{array}{r}-74 \\
-156 \\
-201 \\
-130 \\
-114\end{array}$ & $\begin{array}{r}-40 \\
-82 \\
-124 \\
-72 \\
-72\end{array}$ & $\begin{array}{l}-112 \\
-133\end{array}$ & & & & -129 & $\begin{array}{l}\mathrm{K} 2262 \\
\mathrm{~K} 3133 \\
\mathrm{~K} 1340 \\
\mathrm{~K} 1340\end{array}$ & \\
\hline $\begin{array}{ll}R & 1322 \\
R & 1332 \\
R & 1336 \\
K & 1339 \\
R & 1340\end{array}$ & $\begin{array}{l}403423 \\
404022 \\
404204 \\
403941 \\
404145\end{array}$ & $\begin{array}{l}735954 \\
735937 \\
735602 \\
735541 \\
735757\end{array}$ & $\begin{array}{r}5 \\
10 \\
50 \\
40 \\
25\end{array}$ & $\begin{array}{l}-180 \\
-158 \\
-113 \\
-129 \\
-120\end{array}$ & $\begin{array}{r}-119 \\
-121 \\
-52 \\
-119 \\
-82\end{array}$ & $\begin{array}{l}-150 \\
-158\end{array}$ & -180 & & & -120 & $\mathrm{~K} 2136$ & \\
\hline $\begin{array}{ll}\mathrm{K} & 1343 \\
\mathrm{~K} & 1344 \\
\mathrm{~K} & 1346 \\
\mathrm{~K} & 1354 \\
\mathrm{~K} & 1355\end{array}$ & $\begin{array}{l}403934 \\
404200 \\
404232 \\
403911 \\
403905\end{array}$ & $\begin{array}{l}735539 \\
735701 \\
735532 \\
735832 \\
735628\end{array}$ & $\begin{array}{l}39 \\
10 \\
39 \\
70 \\
46\end{array}$ & $\begin{array}{l}-129 \\
-161 \\
-129 \\
-110 \\
-129\end{array}$ & $\begin{array}{r}-123 \\
-85 \\
-123 \\
-95 \\
-74\end{array}$ & -101 & & & & & $\begin{array}{l}\text { K1346 } \\
\text { K3133 }\end{array}$ & \\
\hline $\begin{array}{ll}K & 1359 \\
K & 1360 \\
K & 1363 \\
K & 1370 \\
K & 1488\end{array}$ & $\begin{array}{l}403908 \\
403904 \\
403923 \\
404338 \\
404147\end{array}$ & $\begin{array}{l}735526 \\
735628 \\
735527 \\
735555 \\
735805\end{array}$ & $\begin{array}{l}28 \\
45 \\
33 \\
27 \\
25\end{array}$ & $\begin{array}{r}-177 \\
-90 \\
-137 \\
-50 \\
-83\end{array}$ & $\begin{array}{r}-112 \\
-70 \\
-131 \\
-75\end{array}$ & & & -48 & & & K1548 & \\
\hline $\begin{array}{ll}\text { K } & 1490 \\
\text { K } & 1494 \\
\text { K } & 1504 \\
\text { K } & 1508 \\
\text { K } & 1510\end{array}$ & $\begin{array}{l}404229 \\
403841 \\
403928 \\
403912 \\
404003\end{array}$ & $\begin{array}{l}735623 \\
740051 \\
735738 \\
735545 \\
735517\end{array}$ & $\begin{array}{l}35 \\
80 \\
64 \\
28 \\
52\end{array}$ & $\begin{array}{l}-100 \\
-164 \\
-116 \\
-118 \\
-153\end{array}$ & $\begin{array}{r}-70 \\
-162 \\
-114 \\
-103 \\
-113\end{array}$ & & & & & & & \\
\hline
\end{tabular}


Table 9.--Hydrogeologic units penetrated by wells and test holes in Kings, Queens, Nassau, Bronx, New York, and Richmond counties (continued)

[Well locations are shown on pl. 1]

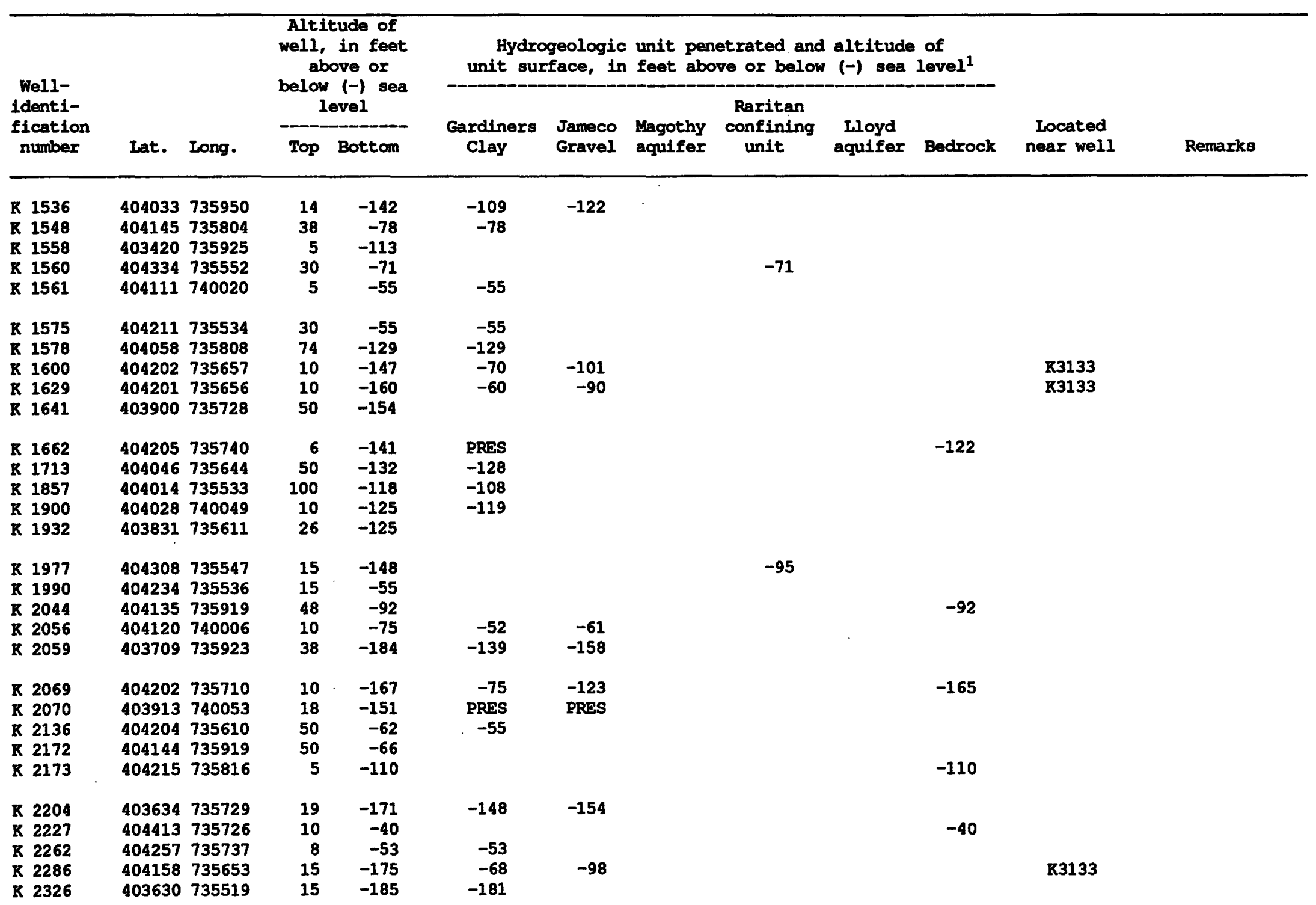


Table 9.--Hydrogeologic units penetrated by wells and test holes in Kings, Queens, Nassau, Bronx, New York, and Richmond Counties (continued)

[Well locations are shown on pl. 1]

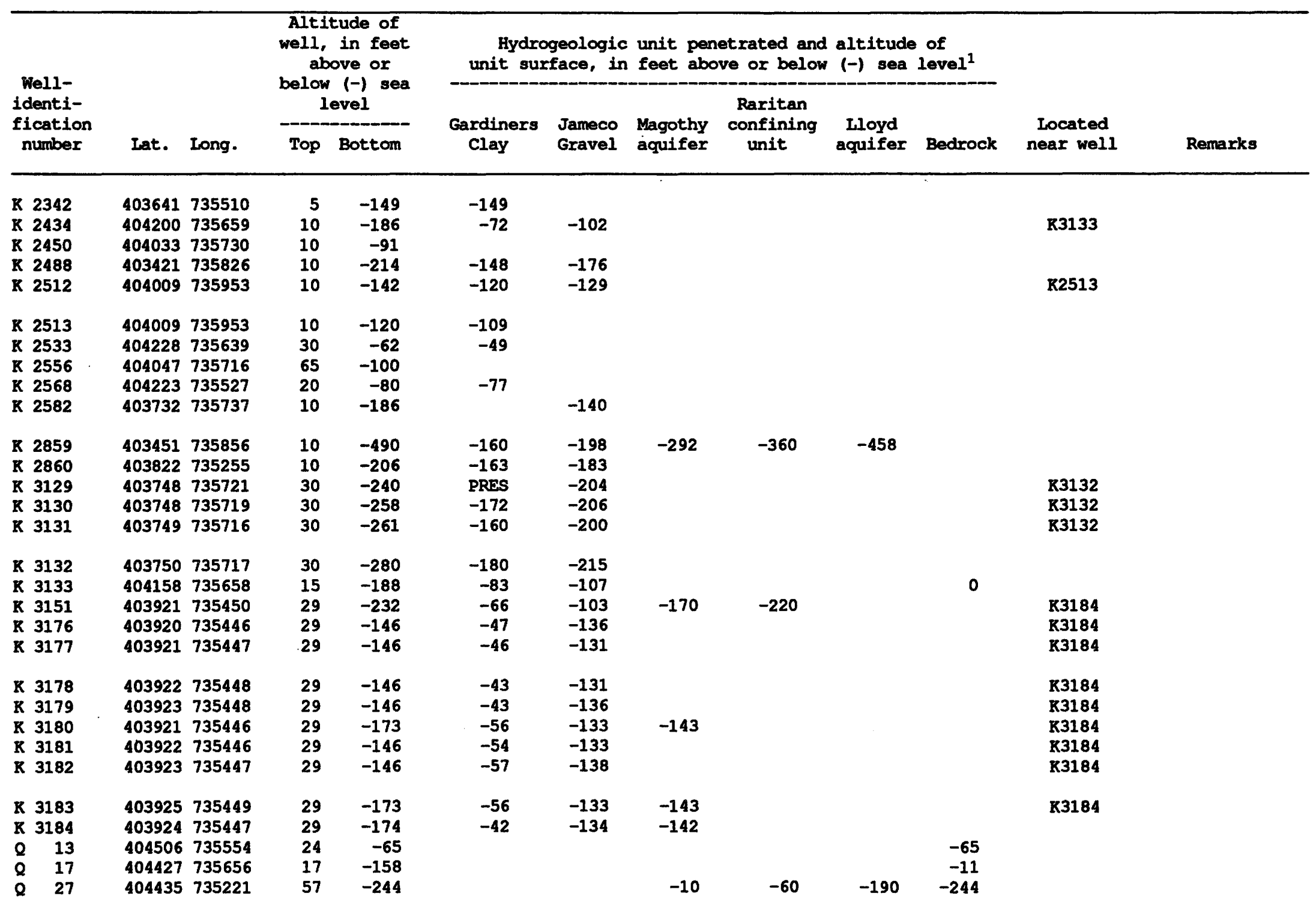

${ }^{1}$ PRES - Unit present but surface altitude not discernible. 
Table 9.-Hydrogeologic units penetrated by wells and test holes in Kings, Queens, Nassau, Bronx, New York, and Richmond Counties (continued)

[พืell locations are shown on pl. 1]

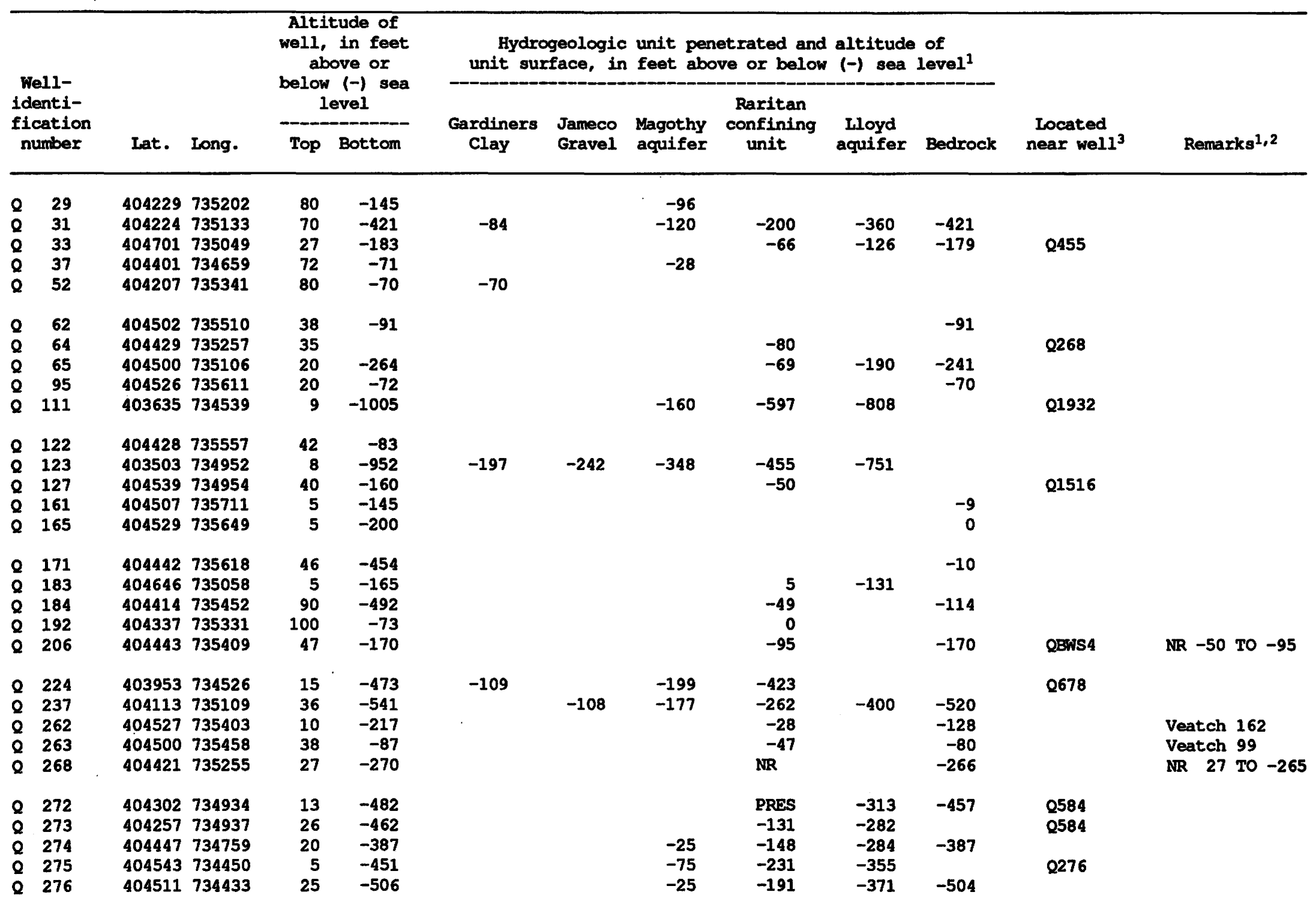


Table 9.-Hydrogeologic units penetrated by wells and test holes in Kings, Queens, Nassau, Bronx, New York, and Richmond Counties (continued)

[Well locations are shown on pl. 1]

\begin{tabular}{|c|c|c|c|c|c|c|c|c|c|c|c|c|c|}
\hline & e & & & $\begin{array}{r}\text { Alti } \\
\text { well, } \\
\text { ab } \\
\text { below }\end{array}$ & $\begin{array}{l}\text { tude of } \\
\text { in feet } \\
\text { ove or } \\
(-) \text { sea }\end{array}$ & $\begin{array}{r}\text { Hydro } \\
\text { unit sur }\end{array}$ & $\begin{array}{l}\text { geologic } \\
\text { face, in }\end{array}$ & $\begin{array}{l}\text { unit pen } \\
\text { feet abo }\end{array}$ & $\begin{array}{l}\text { etrated and } \\
\text { ve or belon }\end{array}$ & $\begin{array}{l}\text { altitude } \\
(-) \text { sea }\end{array}$ & $\begin{array}{l}\text { of } \\
\text { level } 1\end{array}$ & & \\
\hline & enti- & & & & evel & & & & Raritan & & & & \\
\hline & $\begin{array}{l}\text { cation } \\
\text { umber }\end{array}$ & Lat. & Long. & Top & Bottom & $\begin{array}{l}\text { Gardiners } \\
\text { Clay }\end{array}$ & $\begin{array}{l}\text { Jameco } \\
\text { Gravel }\end{array}$ & $\begin{array}{l}\text { Magothy } \\
\text { aquifer }\end{array}$ & $\begin{array}{l}\text { confining } \\
\text { unit }\end{array}$ & $\begin{array}{l}\text { Iloyd } \\
\text { aquifer }\end{array}$ & Bedrock & $\begin{array}{c}\text { Located } \\
\text { near well }\end{array}$ & Remarks \\
\hline $\begin{array}{l}2 \\
2 \\
0 \\
0 \\
0\end{array}$ & $\begin{array}{l}278 \\
282 \\
283 \\
287 \\
290\end{array}$ & $\begin{array}{l}404524 \\
404448 \\
404450 \\
403624 \\
403354\end{array}$ & $\begin{array}{l}734438 \\
734743 \\
734750 \\
734916 \\
735326\end{array}$ & $\begin{array}{r}16 \\
30 \\
27 \\
5 \\
5\end{array}$ & $\begin{array}{l}-520 \\
-433 \\
-420 \\
-712 \\
-723\end{array}$ & $\begin{array}{l}-150 \\
-195\end{array}$ & $\begin{array}{l}-230 \\
-215\end{array}$ & $\begin{array}{r}-59 \\
-38 \\
-41 \\
-315 \\
-280\end{array}$ & $\begin{array}{l}-196 \\
-133 \\
-123 \\
\text { PRES } \\
-485\end{array}$ & $\begin{array}{l}-336 \\
-277 \\
-283 \\
-655 \\
-680\end{array}$ & $\begin{array}{l}-498 \\
-383\end{array}$ & $\begin{array}{l}\mathbf{Q 1 0 5 7} \\
\mathbf{2 2 8 3}\end{array}$ & \\
\hline $\begin{array}{l}Q \\
Q \\
Q \\
Q \\
Q\end{array}$ & $\begin{array}{l}301 \\
306 \\
310 \\
311 \\
312\end{array}$ & $\begin{array}{l}404214 \\
404147 \\
404141 \\
404107 \\
404044\end{array}$ & $\begin{array}{l}734935 \\
734718 \\
734413 \\
734805 \\
734552\end{array}$ & $\begin{array}{l}67 \\
26 \\
47 \\
28 \\
22\end{array}$ & $\begin{array}{r}-43 \\
-71 \\
-64 \\
-232 \\
-254\end{array}$ & $\begin{array}{r}-43 \\
-47 \\
-100 \\
-48\end{array}$ & $\begin{array}{l}-177 \\
-148\end{array}$ & $\begin{array}{r}-58 \\
-242\end{array}$ & & & & $\begin{array}{l}Q 1839 \\
Q 2443 \\
Q 3157\end{array}$ & \\
\hline $\begin{array}{l}Q \\
Q \\
2 \\
0 \\
0\end{array}$ & $\begin{array}{l}333 \\
334 \\
335 \\
336 \\
337\end{array}$ & $\begin{array}{l}403958 \\
403952 \\
404004 \\
404016 \\
404000\end{array}$ & $\begin{array}{l}734502 \\
734535 \\
734620 \\
734716 \\
734742\end{array}$ & $\begin{array}{r}12 \\
8 \\
13 \\
10 \\
8\end{array}$ & $\begin{array}{l}-128 \\
-182 \\
-322 \\
-163 \\
-214\end{array}$ & $\begin{array}{r}-49 \\
-67 \\
-70 \\
-85 \\
-106\end{array}$ & $\begin{array}{l}-64 \\
-147 \\
-135 \\
-163\end{array}$ & $\begin{array}{l}-103 \\
-284\end{array}$ & & & & $\begin{array}{l}\text { Q1197 } \\
\text { Q1305 } \\
\text { Q1876 }\end{array}$ & \\
\hline $\begin{array}{l}0 \\
0 \\
0 \\
0 \\
0\end{array}$ & $\begin{array}{l}338 \\
339 \\
340 \\
341 \\
344\end{array}$ & $\begin{array}{l}403957 \\
404002 \\
404026 \\
404243 \\
403959\end{array}$ & $\begin{array}{l}734805 \\
734830 \\
735135 \\
735134 \\
735005\end{array}$ & $\begin{array}{r}10 \\
10 \\
9 \\
70 \\
10\end{array}$ & $\begin{array}{l}-220 \\
-197 \\
-153 \\
-176 \\
-326\end{array}$ & $\begin{array}{r}-91 \\
-103 \\
\text { PRES }\end{array}$ & $\begin{array}{r}-195 \\
-174 \\
-71 \\
-110\end{array}$ & $\begin{array}{r}-121 \\
-58 \\
-178\end{array}$ & & & & $\begin{array}{l}Q 1175 \\
0634\end{array}$ & \\
\hline $\begin{array}{l}0 \\
0 \\
0 \\
0 \\
0\end{array}$ & $\begin{array}{l}345 \\
350 \\
364 \\
369 \\
374\end{array}$ & $\begin{array}{l}404006 \\
404020 \\
404449 \\
404438 \\
404632\end{array}$ & $\begin{array}{l}735040 \\
735007 \\
735333 \\
735520 \\
735530\end{array}$ & $\begin{array}{l}10 \\
33 \\
63 \\
80 \\
33\end{array}$ & $\begin{array}{r}-209 \\
-622 \\
-126 \\
-72 \\
-31\end{array}$ & & $\begin{array}{l}-143 \\
-103\end{array}$ & $\begin{array}{l}-189 \\
-208\end{array}$ & $\begin{array}{r}-265 \\
-27\end{array}$ & -453 & $\begin{array}{l}-577 \\
-61 \\
-17\end{array}$ & $\begin{array}{l}Q 2384 \\
Q 2148\end{array}$ & \\
\hline
\end{tabular}

${ }^{1}$ PRES - Unit present but surface altitude not discernible.

NR - No record; no record near altitudes indicated under remarks.

${ }^{2}$ Veatch - Well number from numbering system employed in Veatch and others, 1906.

${ }^{3}$ BWS - New York City Bureau of Water Supply Well 
Table 9.--Hydrogeologic units penetrated by wells and test holes in Kings, Queans, Nassau, Bronx, New York, and Richmond Counties (continued)

[Well locations are shown on pl. 1]

\begin{tabular}{|c|c|c|c|c|c|c|c|c|c|c|c|}
\hline \multirow{3}{*}{$\begin{array}{l}\text { Nell- } \\
\text { identi- } \\
\text { fication } \\
\text { number }\end{array}$} & \multirow[b]{3}{*}{ Lat. } & \multirow[b]{3}{*}{ Iong. } & \multirow{2}{*}{$\begin{array}{l}\text { Altitude of } \\
\text { well, in feet } \\
\text { above or } \\
\text { below (-) sea } \\
\text { level }\end{array}$} & \multicolumn{6}{|c|}{$\begin{array}{l}\text { Hydrogeologic unit penetrated and altitude of } \\
\text { unit surface, in feet above or below }(-) \text { sea level }\end{array}$} & \multirow{3}{*}{$\begin{array}{l}\text { Located } \\
\text { near well }\end{array}$} & \multirow[b]{3}{*}{ Remarks } \\
\hline & & & & \multirow{2}{*}{$\begin{array}{l}\text { Gardiners } \\
\text { Clay }\end{array}$} & \multirow{2}{*}{$\begin{array}{l}\text { Jameco } \\
\text { Gravel }\end{array}$} & \multirow{2}{*}{$\begin{array}{l}\text { Magothy } \\
\text { aquifer }\end{array}$} & \multirow{2}{*}{$\begin{array}{l}\text { Raritan } \\
\text { confining } \\
\text { unit }\end{array}$} & \multirow{2}{*}{$\begin{array}{l}\text { Lloyd } \\
\text { aquifer }\end{array}$} & \multirow[b]{2}{*}{ Bedrock } & & \\
\hline & & & Top Bottom & & & & & & & & \\
\hline
\end{tabular}

$0 \quad 375 \quad 404633735558$

$\begin{array}{lllll}Q & 375 & 404633 & 735558 \\ Q & 376 & 404518 & 735521 \\ Q & 377 & 404539 & 735503 \\ Q & 378 & 404549 & 735455 \\ Q & 379 & 404529 & 735512\end{array}$

$\begin{array}{ll}15 & -43 \\ 43 & -79 \\ 64 & -23 \\ 75 & -28 \\ 52 & -95\end{array}$

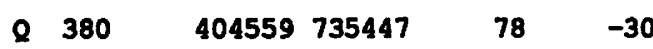

$\begin{array}{llllll}0 & 381 & 404647 & 735354 & 19 & -76\end{array}$

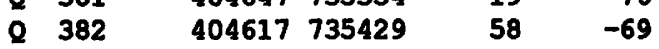

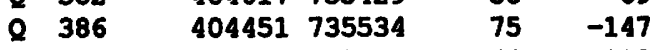

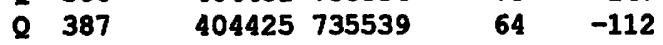

-41
-59
-3
-8
-74

$\begin{array}{llllll}2 & 388 & 404433 & 735536 & 70 & -133\end{array}$

$\begin{array}{lllllr}0 & 389 & 404508 & 735529 & 35 & -49 \\ 0 & 390 & 404351 & 735605 & 23 & -188\end{array}$

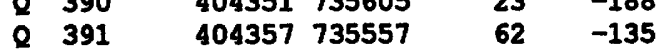

Q $392 \quad 404403735549 \quad 65 \quad-101$

$\begin{array}{llllll}Q & 393 & 404345 & 735557 & 17 & -153\end{array}$

$\begin{array}{llllll}2 & 394 & 404411 & 735542 & 48 & -127\end{array}$

$\begin{array}{llllll}2 & 395 & 404422 & 735704 & 7 & -67\end{array}$

$0 \quad 398 \quad 404437735642$

Q $399 \quad 404447735653$

Q $403 \quad 403352735440$

$\begin{array}{llll}2 & 404 & 404652 & 735517\end{array}$

Q $405 \quad 404702735347$

Q $406 \quad 404646735514$

$0 \quad 407 \quad 404623735521$

$2408 \quad 404610735608$

Q $411 \quad 404609735435$

$0412 \quad 404549735424$

$\begin{array}{lll}2 & 413 & 404612735510\end{array}$

$\begin{array}{llll}Q & 413 & 404612 & 735510 \\ Q & 414 & 404618 & 735352\end{array}$

$\begin{array}{rr}2 & -65 \\ 13 & -55\end{array}$

$\begin{array}{rr}5 & -865 \\ 43 & -3 \\ 0 & -95 \\ 53 & -29 \\ 22 & -28 \\ & \\ 6 & -51 \\ 64 & -61 \\ 66 & -62 \\ 56 & -55 \\ 21 & -102\end{array}$

-41
-59
-3
-8
-74
-10
-56
-51
-73
-88

-106
-28
-171
-115
-85

-133
-107
-67

$\begin{array}{llllll}-192 & -206 & -237 & -486 & -643 & -865\end{array}$


Table 9.--Hydrogeologic units penetrated by wells and test holes in Kings, Queens, Nassau, Bronx, New York, and Richmond Counties (continued)

[Well locations are shown on pl. 1]

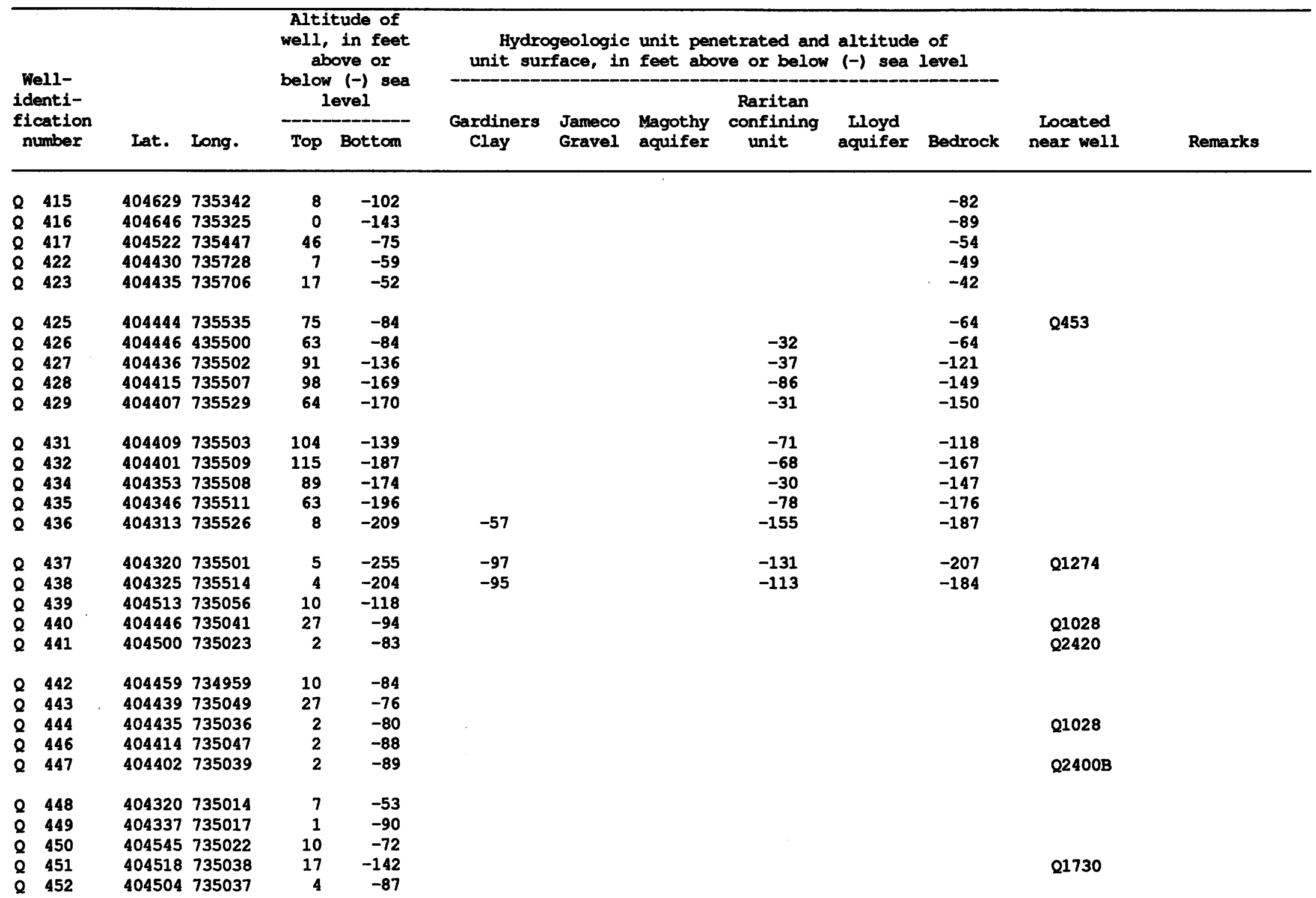


Table 9.-Hydrogeologic units penetrated by wells and test holes in Kings, Queens, Nassau, Bronx, New York, and Richmond Counties (continued)

[Well locations are shown on pl. 1]

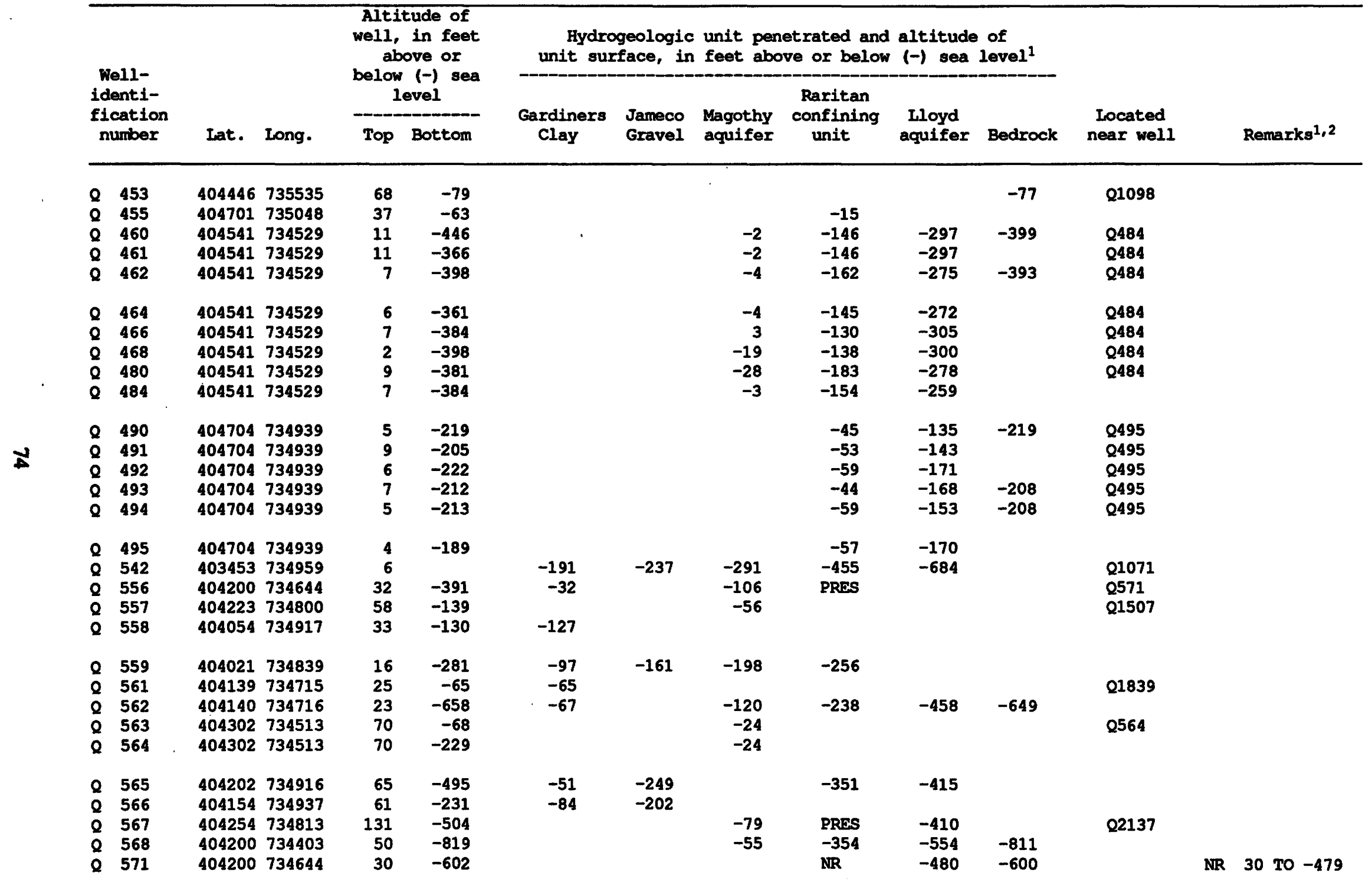


Table 9.--Hydrogeologic units penetrated by wells and test holes in Kings, Queens, Nassau, Bronx, New York, and Richmond Counties (continued)

[Well locations are shown on pl. 1]

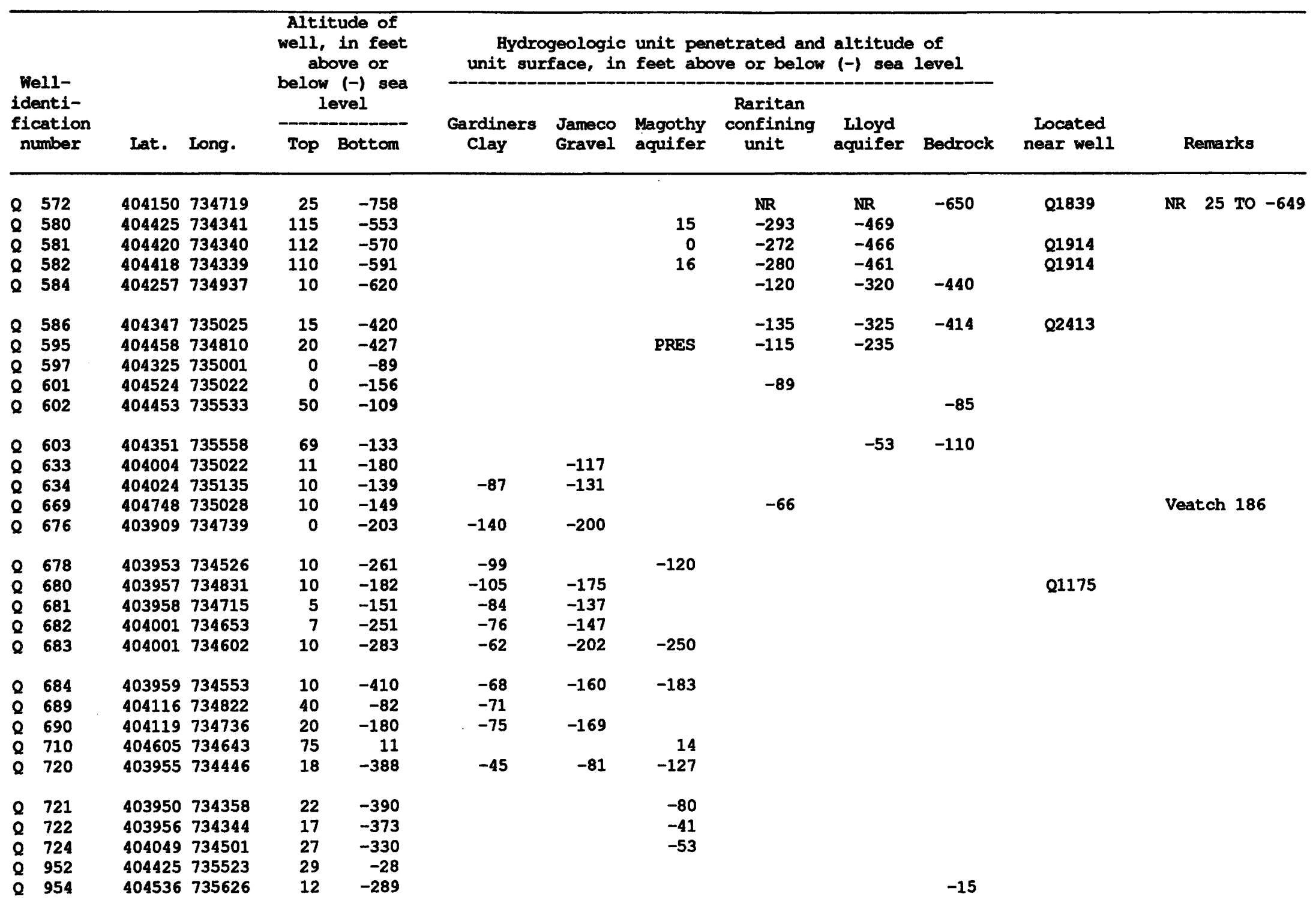

${ }^{1}$ PRFS - Unit present but surface altitude not discernible.

NR - No record; no record near altitudes indicated under remarks.

${ }^{2}$ Veatch - Well number from numbering system employed in Veatch and others, 1906. 
Table 9.--Hydrogeologic units penetrated by wells and test holes in Kings, Queens, Nassau, Bronx, New York, and Richmond Counties (continued)

[Well locations are shown on pl. 1]

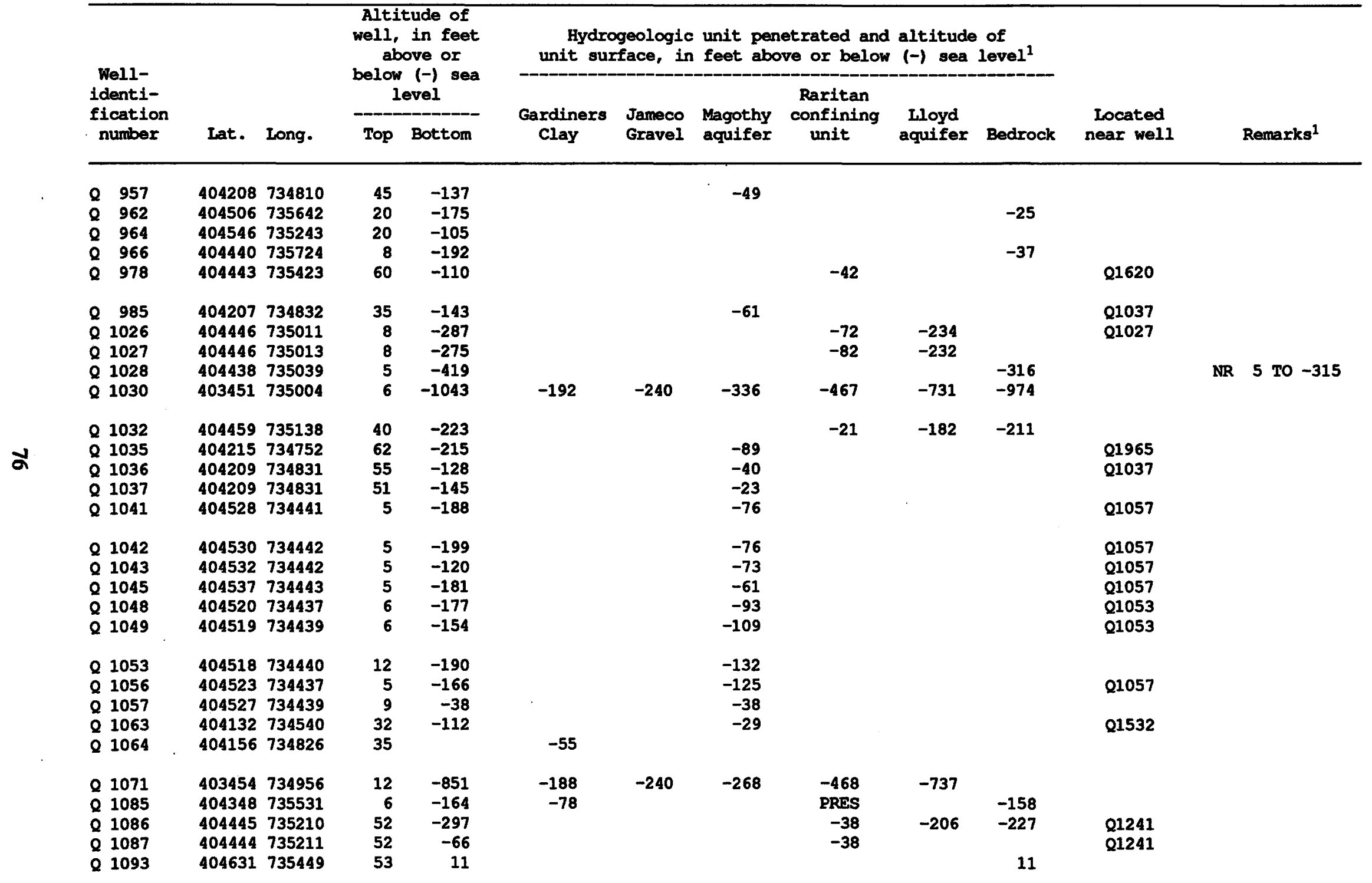


Table 9.-Hydrogeologic units penetrated by wells and test holes in Kings, Queens, Nassau, Bronx, New York, and Richmond Counties (continued)

[Well locations are shown on pl. 1]

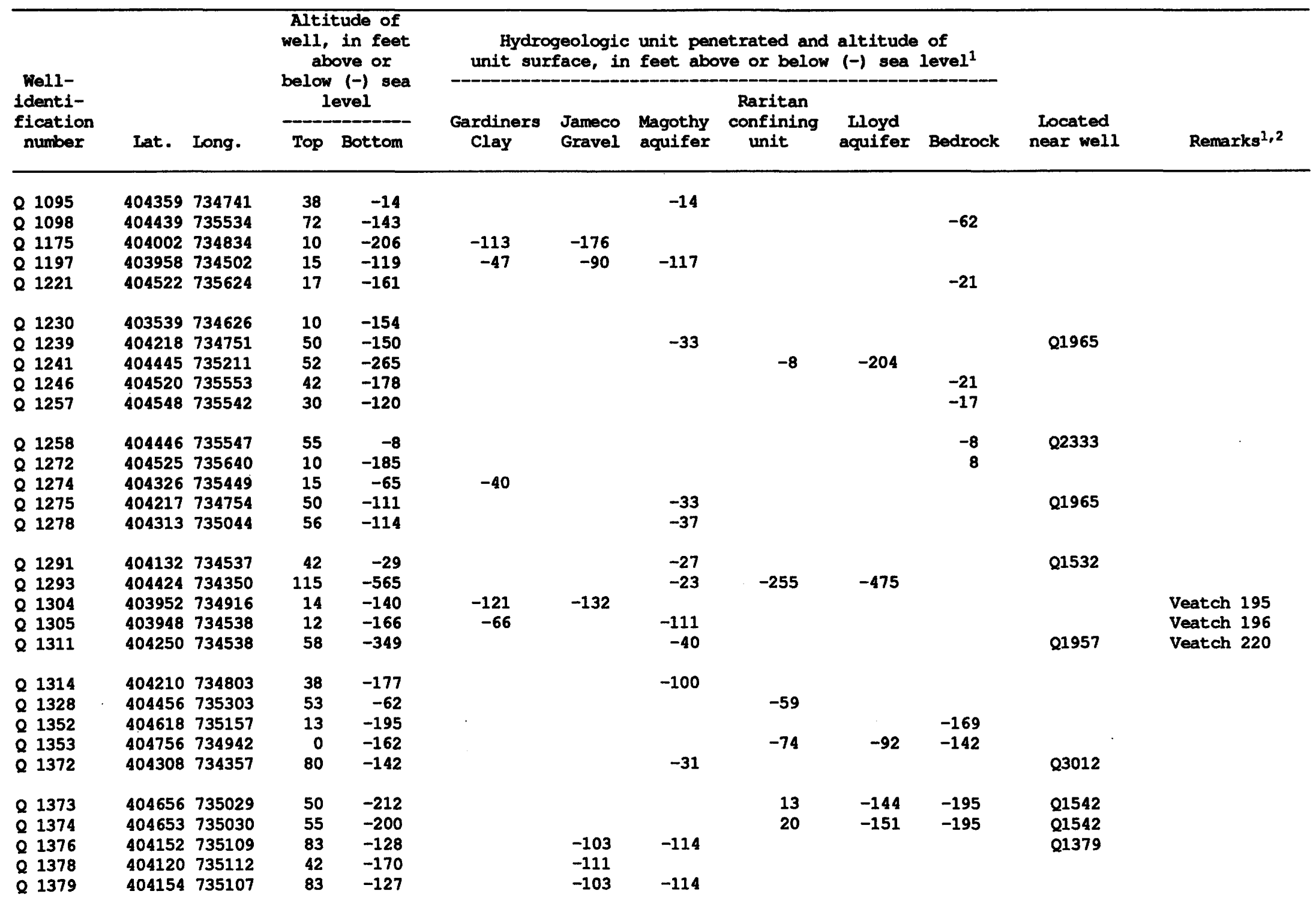

${ }^{1}$ PRES - Unit present but surface altitude not discernible.

NR - No record; no record near altitudes indicated under remarks.

2veatch - Well number from numbering system employed in Veatch and others, 1906. 
Table 9.-Hydrogeologic units penetrated by wells and test holes in Kings, Queens, Nassau, Bronx, Now York, and Richmond counties (continued)

[Well locations are shown on pl. 1]

\begin{tabular}{|c|c|c|c|c|c|c|c|c|c|c|c|c|}
\hline \multirow{3}{*}{$\begin{array}{l}\text { Well- } \\
\text { identi- } \\
\text { fication } \\
\text { number }\end{array}$} & \multirow[b]{3}{*}{ Iat. } & \multirow[b]{3}{*}{ Long. } & \multirow{2}{*}{\multicolumn{2}{|c|}{$\begin{array}{l}\text { Altitude of } \\
\text { well, in feet } \\
\text { above or } \\
\text { below ( }-) \text { sea } \\
\text { level }\end{array}$}} & \multicolumn{6}{|c|}{$\begin{array}{l}\text { Hydrogeologic unit penetrated and altitude of } \\
\text { unit surface, in feet above or below }(-) \text { sea level }\end{array}$} & \multirow{3}{*}{$\begin{array}{l}\text { Located } \\
\text { near well }\end{array}$} & \multirow[b]{3}{*}{ Remarks } \\
\hline & & & & & \multirow[b]{2}{*}{$\begin{array}{l}\text { Gardiners } \\
\text { Clay }\end{array}$} & \multirow[b]{2}{*}{$\begin{array}{l}\text { Jameco } \\
\text { Gravel }\end{array}$} & \multirow[b]{2}{*}{$\begin{array}{l}\text { Magothy } \\
\text { aquifer }\end{array}$} & \multirow{2}{*}{$\begin{array}{l}\text { Raritan } \\
\text { confining } \\
\text { unit }\end{array}$} & \multirow[b]{2}{*}{$\begin{array}{l}\text { Lloyd } \\
\text { aquifer }\end{array}$} & \multirow[b]{2}{*}{ Bedrock } & & \\
\hline & & & Top & Bottom & & & & & & & & \\
\hline $\begin{array}{ll}\mathbf{Q} & 1383 \\
\mathbf{Q} & 1384 \\
\mathbf{Q} & 1392 \\
\mathbf{Q} & 1400 \\
\mathbf{Q} & 1412\end{array}$ & $\begin{array}{l}403610 \\
404308 \\
404227 \\
404401 \\
404259\end{array}$ & $\begin{array}{l}734514 \\
734357 \\
734750 \\
735229 \\
735427\end{array}$ & $\begin{array}{l}26 \\
80 \\
60 \\
20 \\
42\end{array}$ & $\begin{array}{r}-224 \\
-152 \\
-301 \\
-282 \\
-98\end{array}$ & & & $\begin{array}{r}-114 \\
-26 \\
-72\end{array}$ & $\begin{array}{r}-260 \\
-58 \\
-78\end{array}$ & -238 & -281 & $\begin{array}{l}Q 3012 \\
Q 1507\end{array}$ & \\
\hline $\begin{array}{ll}Q & 1423 \\
Q & 1447 \\
Q & 1449 \\
Q & 1450 \\
Q & 1465\end{array}$ & $\begin{array}{l}404233 \\
404148 \\
404107 \\
404207 \\
404604\end{array}$ & $\begin{array}{l}734630 \\
734847 \\
734805 \\
734459 \\
735025\end{array}$ & $\begin{array}{l}55 \\
45 \\
28 \\
55 \\
12\end{array}$ & $\begin{array}{r}-247 \\
-90 \\
-108 \\
-77 \\
-115\end{array}$ & $\begin{array}{r}-84 \\
-103\end{array}$ & & $\begin{array}{l}-85 \\
-62\end{array}$ & -59 & & & $\begin{array}{l}Q 2356 \\
Q 3157 \\
Q 1815\end{array}$ & \\
\hline $\begin{array}{ll}\mathbf{Q} & 1472 \\
\mathbf{Q} & 1477 \\
\mathbf{Q} & 1483 \\
\mathbf{Q} & 1493 \\
\mathbf{Q} & 1497\end{array}$ & $\begin{array}{l}404415 \\
404050 \\
404055 \\
404140 \\
404653\end{array}$ & $\begin{array}{l}734657 \\
735022 \\
735118 \\
735041 \\
735030\end{array}$ & $\begin{array}{l}70 \\
34 \\
25 \\
45 \\
55\end{array}$ & $\begin{array}{r}-184 \\
-144 \\
-159 \\
-98 \\
-169\end{array}$ & -82 & $\begin{array}{l}-111 \\
-120\end{array}$ & $\begin{array}{r}-75 \\
-143\end{array}$ & 25 & -130 & -169 & 23000 & \\
\hline $\begin{array}{ll}0 & 1498 \\
Q & 1502 \\
Q & 1503 \\
0 & 1507 \\
Q & 1511\end{array}$ & $\begin{array}{l}404653 \\
404426 \\
404316 \\
404222 \\
404139\end{array}$ & $\begin{array}{l}735030 \\
735614 \\
734837 \\
734750 \\
735105\end{array}$ & $\begin{array}{l}55 \\
15 \\
75 \\
58 \\
48\end{array}$ & $\begin{array}{r}-169 \\
-78 \\
-32 \\
-99 \\
-97\end{array}$ & & & $\begin{array}{l}-32 \\
-94\end{array}$ & 25 & -130 & $\begin{array}{r}-169 \\
-76\end{array}$ & $\begin{array}{l}\text { Q1542 } \\
\text { QBWS2 }\end{array}$ & \\
\hline $\begin{array}{ll}2 & 1516 \\
Q & 1521 \\
Q & 1528 \\
Q & 1532 \\
Q & 1535\end{array}$ & $\begin{array}{l}404539 \\
404029 \\
404137 \\
404134 \\
404249\end{array}$ & $\begin{array}{l}734957 \\
734553 \\
735158 \\
734542 \\
734435\end{array}$ & $\begin{array}{l}35 \\
20 \\
70 \\
40 \\
70\end{array}$ & $\begin{array}{r}-77 \\
-162 \\
-118 \\
-414 \\
-380\end{array}$ & -44 & $\begin{array}{l}-126 \\
-114\end{array}$ & $\begin{array}{l}-21 \\
-39\end{array}$ & $\begin{array}{l}-334 \\
-356\end{array}$ & & & Q1629 & \\
\hline $\begin{array}{ll}Q & 1536 \\
Q & 1542 \\
Q & 1600 \\
Q & 1619 \\
Q & 1620\end{array}$ & $\begin{array}{l}404324 \\
404653 \\
404330 \\
404554 \\
404439\end{array}$ & $\begin{array}{l}734554 \\
735030 \\
734503 \\
735558 \\
735413\end{array}$ & $\begin{array}{r}190 \\
53 \\
98 \\
15 \\
60\end{array}$ & $\begin{array}{r}-83 \\
-171 \\
-356 \\
-28 \\
-173\end{array}$ & & & $\begin{array}{l}-73 \\
-12\end{array}$ & $\begin{array}{r}23 \\
-283 \\
-42\end{array}$ & -132 & $\begin{array}{r}-171 \\
-27 \\
-170\end{array}$ & 01747 & \\
\hline
\end{tabular}


Table 9.--Hydrogeologic units penetrated by wells and test holes in Kings, Queens, Nassau, Bronx, New York, and Richmond Counties (continued)

[Well locations are shown on pl. 1]

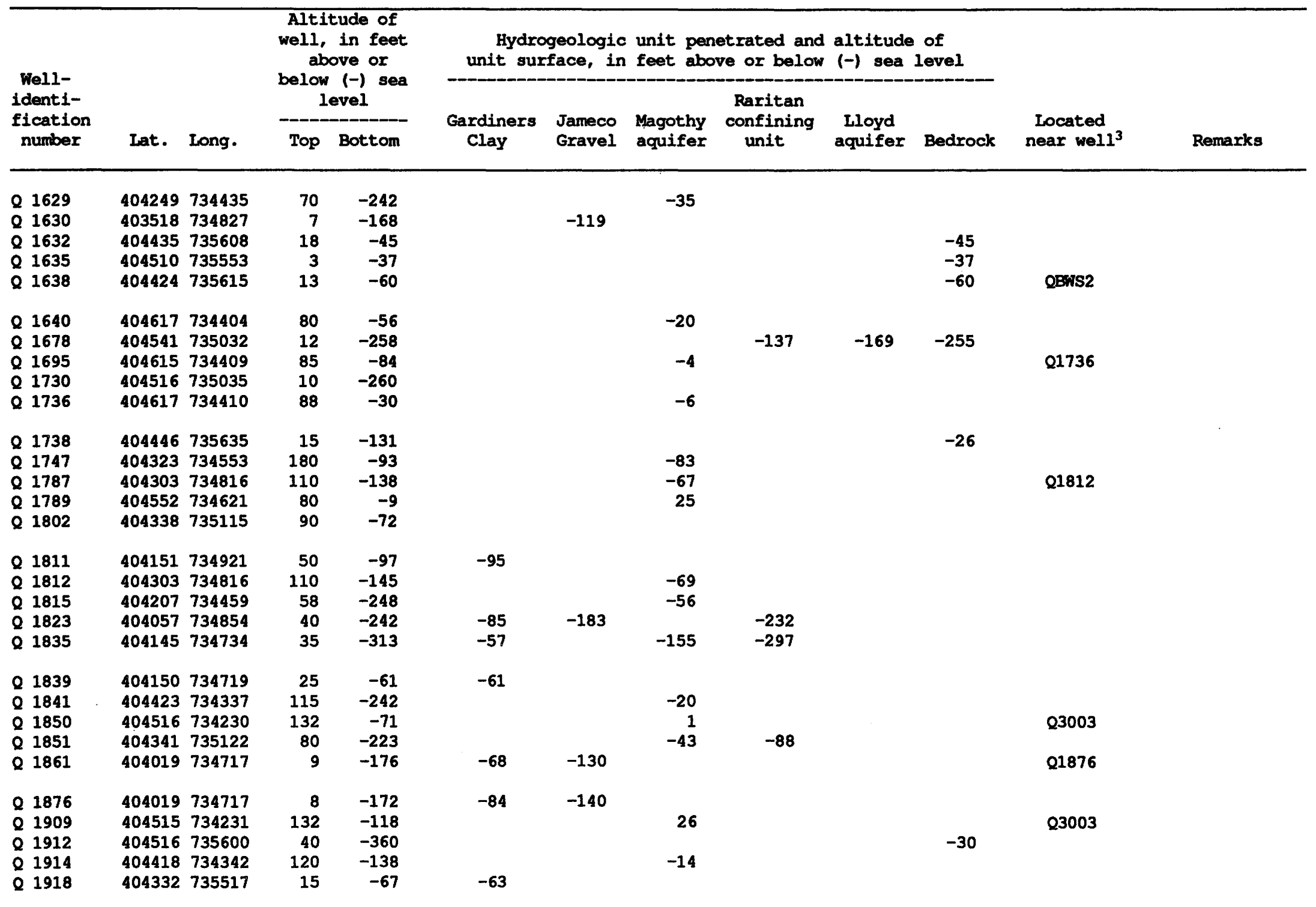

3BWS - New York City Bureau of Water Supply Well 
Table 9.--Hydrogeologic units penetrated by wells and test holes in Kings, Queens, Nassau, Bronx, New York, and Richmond Counties (continued)

[Well locations are shown on pl. 1]

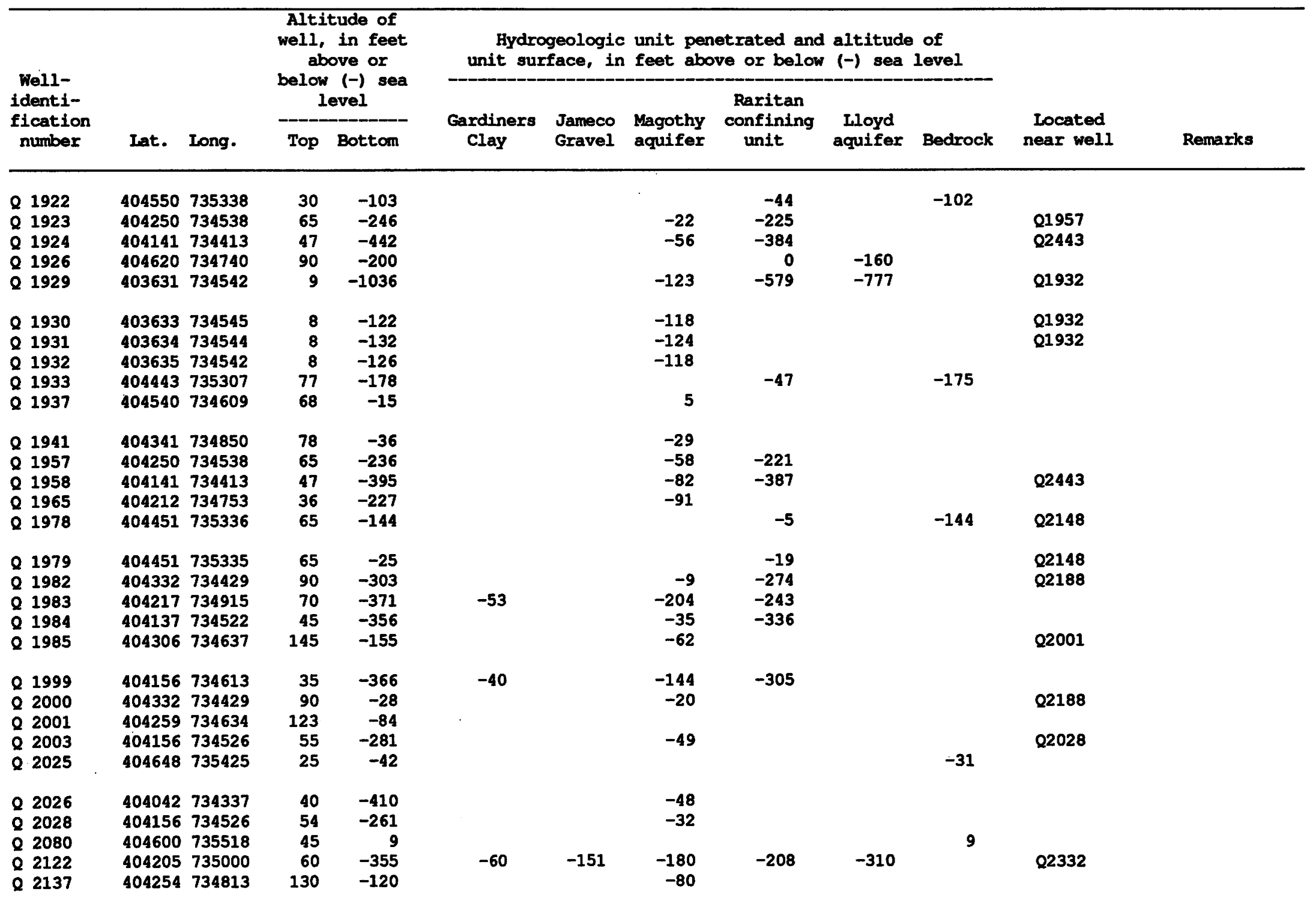


Table 9.--Hydrogeologic units penetrated by wells and test holes in Kings, Queens, Nassau, Bronx, New York, and Richmond counties (continued)

[Well locations are shown on pl. 1]

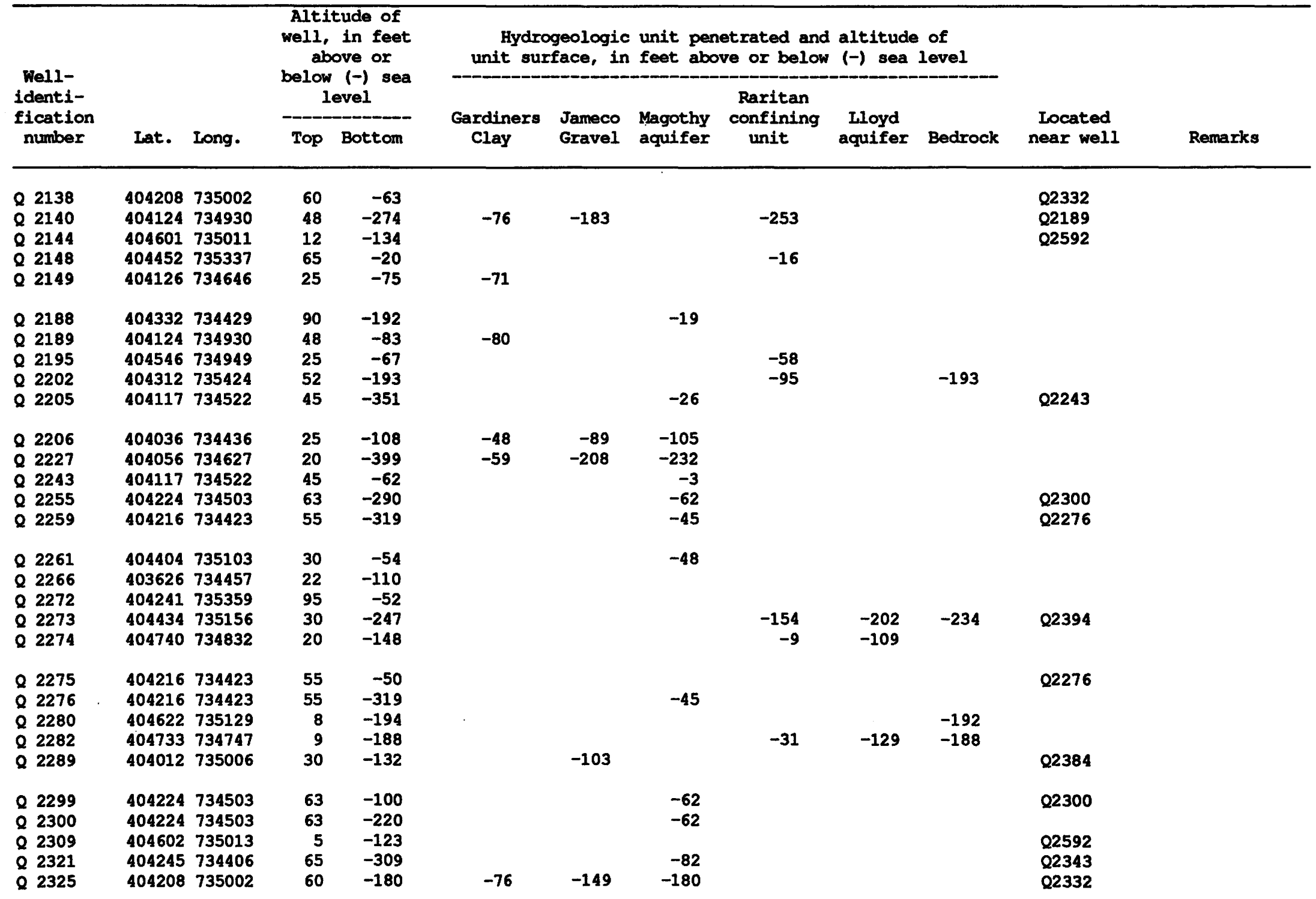


Table 9.--Hydrogeologic units penetrated by wells and test holes in Kings, Queens, Nassau, Bronx, New York, and Richmond counties (continued)

[Well locations are shown on pl. 1]

\begin{tabular}{|c|c|c|c|c|c|c|c|c|c|c|c|c|}
\hline \multirow{3}{*}{$\begin{array}{l}\text { Well- } \\
\text { identi- } \\
\text { fication } \\
\text { number }\end{array}$} & \multirow[b]{3}{*}{ Iat. } & \multirow[b]{3}{*}{ Long. } & \multirow{2}{*}{\multicolumn{2}{|c|}{$\begin{array}{l}\text { Altitude of } \\
\text { well, in feet } \\
\text { above or } \\
\text { below (-) sea } \\
\text { level }\end{array}$}} & \multicolumn{6}{|c|}{$\begin{array}{l}\text { Hydrogeologic unit penetrated and altitude of } \\
\text { unit surface, in feet above or below }(-) \text { sea level }\end{array}$} & \multirow{3}{*}{$\begin{array}{l}\text { Located } \\
\text { near well }\end{array}$} & \multirow[b]{3}{*}{ Remarks } \\
\hline & & & & & \multirow{2}{*}{$\begin{array}{l}\text { Gardiners } \\
\text { Clay }\end{array}$} & \multirow{2}{*}{$\begin{array}{l}\text { Jameco } \\
\text { Gravel }\end{array}$} & \multirow{2}{*}{$\begin{array}{l}\text { Magothy } \\
\text { aquifer }\end{array}$} & \multirow{2}{*}{$\begin{array}{l}\text { Raritan } \\
\text { confining } \\
\text { unit }\end{array}$} & \multirow{2}{*}{$\begin{array}{l}\text { Lloyd } \\
\text { aquifer }\end{array}$} & \multirow[b]{2}{*}{ Bedrock } & & \\
\hline & & & Top & Bottom & & & & & & & & \\
\hline $\begin{array}{ll}0 & 2329 \\
0 & 2331 \\
0 & 2332 \\
Q & 2333 \\
Q & 2343\end{array}$ & $\begin{array}{l}404159 \\
404703 \\
404208 \\
404443 \\
404245\end{array}$ & $\begin{array}{l}734629 \\
734905 \\
735002 \\
735601 \\
734406\end{array}$ & $\begin{array}{l}30 \\
65 \\
60 \\
25 \\
65\end{array}$ & $\begin{array}{r}-79 \\
-40 \\
-192 \\
-12 \\
-175\end{array}$ & -71 & -151 & $\begin{array}{r}-165 \\
-77\end{array}$ & -38 & & -12 & & \\
\hline $\begin{array}{ll}Q & 2349 \\
Q & 2356 \\
Q & 2361 \\
Q & 2362 \\
Q & 2363\end{array}$ & $\begin{array}{l}403935 \\
404234 \\
404329 \\
404320 \\
404343\end{array}$ & $\begin{array}{l}734515 \\
734629 \\
734827 \\
734818 \\
734831\end{array}$ & $\begin{array}{l}10 \\
50 \\
74 \\
82 \\
64\end{array}$ & $\begin{array}{r}-80 \\
-165 \\
-262 \\
-244 \\
-366\end{array}$ & -70 & & $\begin{array}{l}-97 \\
-33 \\
-63 \\
-30\end{array}$ & $\begin{array}{l}-198 \\
-205 \\
-184\end{array}$ & -347 & & 22409 & \\
\hline $\begin{array}{ll}Q & 2364 \\
Q & 2366 \\
Q & 2373 \\
Q & 2374 \\
Q & 2377\end{array}$ & $\begin{array}{l}404323 \\
404559 \\
404323 \\
404323 \\
404510\end{array}$ & $\begin{array}{l}734838 \\
735512 \\
734838 \\
734838 \\
735005\end{array}$ & $\begin{array}{l}74 \\
45 \\
74 \\
74 \\
20\end{array}$ & $\begin{array}{r}-264 \\
2 \\
-193 \\
-193 \\
-250\end{array}$ & & & $\begin{array}{l}-32 \\
-31 \\
-31\end{array}$ & $\begin{array}{l}-177 \\
-181 \\
-181\end{array}$ & & -248 & 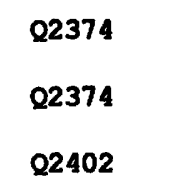 & \\
\hline $\begin{array}{ll}Q & 2378 \\
Q & 2384 \\
Q & 2385 \\
Q & 2386 \\
Q & 2390\end{array}$ & $\begin{array}{l}404718 \\
404022 \\
404343 \\
404411 \\
404434\end{array}$ & $\begin{array}{l}734622 \\
734957 \\
735008 \\
735042 \\
735159\end{array}$ & $\begin{array}{r}12 \\
27 \\
5 \\
5 \\
35\end{array}$ & $\begin{array}{r}-162 \\
-126 \\
-99 \\
-130 \\
-252\end{array}$ & & -111 & & $\begin{array}{l}-120 \\
-134\end{array}$ & -232 & & $\begin{array}{l}Q 2400 B \\
Q 2394\end{array}$ & \\
\hline 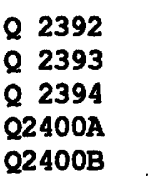 & $\begin{array}{l}404349 \\
404434 \\
404434 \\
404404 \\
404404\end{array}$ & $\begin{array}{l}735009 \\
735159 \\
735158 \\
735040 \\
735040\end{array}$ & $\begin{array}{r}5 \\
35 \\
35 \\
13 \\
18\end{array}$ & $\begin{array}{l}-160 \\
-130 \\
-115 \\
-104 \\
-121\end{array}$ & & & & $\begin{array}{r}-129 \\
-88\end{array}$ & & & $\begin{array}{l}02394 \\
02400 B\end{array}$ & \\
\hline $\begin{array}{ll}Q & 2402 \\
Q & 2404 \\
Q & 2405 \\
Q & 2408 \\
Q & 2409\end{array}$ & $\begin{array}{l}404509 \\
404352 \\
404248 \\
404329 \\
404329\end{array}$ & $\begin{array}{l}735011 \\
734449 \\
734602 \\
734827 \\
734827\end{array}$ & $\begin{array}{r}20 \\
160 \\
62 \\
74 \\
74\end{array}$ & $\begin{array}{r}-253 \\
-250 \\
-288 \\
-85 \\
-207\end{array}$ & & & $\begin{array}{l}-30 \\
-75 \\
-32 \\
-32\end{array}$ & $\begin{array}{l}-250 \\
-224 \\
-183\end{array}$ & & -253 & $\begin{array}{l}Q 2435 \\
22432 \\
\mathbf{2} 409\end{array}$ & \\
\hline
\end{tabular}


Table 9.--Hydrogeologic units penetrated by wells and test holes in Kings, Queens, Nassau, Bronx, New York, and Richmond Counties (continued)

[Well locations are shown on pl. 1]

\begin{tabular}{|c|c|c|c|c|c|c|c|c|c|c|c|}
\hline \multirow{3}{*}{$\begin{array}{l}\text { Nell- } \\
\text { identi- } \\
\text { fication } \\
\text { number }\end{array}$} & \multirow[b]{3}{*}{ Iat. } & \multirow[b]{3}{*}{ Iong. } & \multirow{2}{*}{$\begin{array}{c}\text { Altitude of } \\
\text { well, in feet } \\
\text { above or } \\
\text { below (-) sea } \\
\text { level }\end{array}$} & \multicolumn{2}{|c|}{$\begin{array}{r}\text { Hydrogeologic } \\
\text { unit surface, in }\end{array}$} & \multicolumn{2}{|c|}{$\begin{array}{l}\text { unit penetrated and } \\
\text { feet above or below }\end{array}$} & \multicolumn{2}{|c|}{$\begin{array}{l}\text { altitude of } \\
(-) \text { sea level }\end{array}$} & \multirow[b]{3}{*}{$\begin{array}{c}\text { Located } \\
\text { near well }\end{array}$} & \multirow[b]{3}{*}{ Remarks } \\
\hline & & & & \multirow[b]{2}{*}{$\begin{array}{l}\text { Gardiners } \\
\text { Clay }\end{array}$} & \multirow[b]{2}{*}{$\begin{array}{l}\text { Jameco } \\
\text { Gravel }\end{array}$} & \multirow[b]{2}{*}{$\begin{array}{l}\text { Magothy } \\
\text { aquifer }\end{array}$} & \multirow{2}{*}{$\begin{array}{l}\text { Raritan } \\
\text { confining } \\
\text { unit }\end{array}$} & \multirow[b]{2}{*}{$\begin{array}{l}\text { Lloyd } \\
\text { aguifer }\end{array}$} & \multirow[b]{2}{*}{ Bedrock } & & \\
\hline & & & Top Bottom & & & & & & & & \\
\hline
\end{tabular}

$02410 \quad 404411735019 \quad 5 \quad-195$

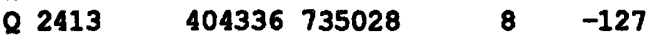

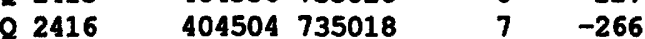

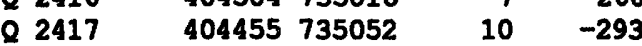

$02419404503735019 \quad 7 \quad-264$

Q $2420 \quad 404503735020 \quad 7 \quad-267$

$\begin{array}{lllll}0 & 2422 & 404025734638 & 20 & -361\end{array}$

$\begin{array}{lllll}02426 & 403919 & 734420 & 6 & -238\end{array}$

$2430 \quad 404135734402$

$02432 \quad 404248734602$

Q $2435 \quad 404352734449$

Q $2437 \quad 404329735214$

$2443 \quad 404135734402$

Q $2445 \quad 404500735606$

Q $2468 \quad 404627735024$

Q $2588 \quad 404512734456$

Q $2592 \quad 404603735008$

Q $2600 \quad 404506734613$

O $2685 \quad 404412734538$

○ $2706 \quad 404245735017$

Q $2712 \quad 404450734402$

Q 2721 . 404507735620

Q $2765 \quad 404038734450$

$02791 \quad 404624734835$

Q $2837 \quad 404237735136$

Q $2955 \quad 404040734451$

02987

Q 2988

02990

Q 2991

404515734231

404402734858

404129734849

404310734700 $\begin{array}{ll}47 & -413 \\ 62 & -230\end{array}$

-63
-44

$-163$

$\begin{array}{ll}160 & -202\end{array}$

$80-118$

$47-319$

$\begin{array}{lr}26 & -84 \\ 10 & -165\end{array}$

$-165$

$-67$

$-238$

$-25$

$-41$

$-66$

$-53$

$-265$

$-425$

$-60$

$-120$

$-80$

$-430$

$-327$

$-360$

$-264$

$-404$

$-115$
$-122$

$-54 \quad-200$

$-71 \quad-213$

$-73 \quad-216$

$-383$

$-225$

-53
-89

$-34$

-87
-64

$-92$

$10-140$

$-238$

$-11$

$-28$

$-66$

18

$-40$

$-164$
Q2420

$\mathbf{Q 2 4 2 0}$

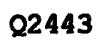

15

$\mathbf{Q 2 9 5 5}$

$\mathbf{Q 3 0 0 3}$

Q3014 
Table 9.--Hydrogeologic units penetrated by wells and test holes in Kings, Queens, Nassau, Bronx, New York, and Richmond Counties (continued)

[Well locations are shown on pl. 1]

\begin{tabular}{|c|c|c|c|c|c|c|c|c|c|c|c|c|}
\hline \multirow{3}{*}{$\begin{array}{l}\text { Pell- } \\
\text { identi- } \\
\text { fication } \\
\text { number }\end{array}$} & \multirow[b]{3}{*}{ Lat. } & \multirow[b]{3}{*}{ Iong. } & \multirow{2}{*}{\multicolumn{2}{|c|}{$\begin{array}{l}\text { Altitude of } \\
\text { well, in feet } \\
\text { above or } \\
\text { below (-) sea } \\
\text { level }\end{array}$}} & \multicolumn{6}{|c|}{$\begin{array}{l}\text { Hydrogeologic unit penetrated and altitude of } \\
\text { unit surface, in feet above or below }(-) \text { sea level }\end{array}$} & \multirow{3}{*}{$\begin{array}{l}\text { Located } \\
\text { near well }\end{array}$} & \multirow[b]{3}{*}{ Remarks } \\
\hline & & & & & \multirow{2}{*}{$\begin{array}{l}\text { Gardiners } \\
\text { Clay }\end{array}$} & \multirow{2}{*}{$\begin{array}{l}\text { Jameco } \\
\text { Gravel }\end{array}$} & \multirow{2}{*}{$\begin{array}{l}\text { Magothy } \\
\text { aquifer }\end{array}$} & \multirow{2}{*}{$\begin{array}{l}\text { Raritan } \\
\text { confining } \\
\text { unit }\end{array}$} & \multirow{2}{*}{$\begin{array}{l}\text { Lloyd } \\
\text { aquifer }\end{array}$} & \multirow[b]{2}{*}{ Bedrock } & & \\
\hline & & & Top & Bottom & & & & & & & & \\
\hline $\begin{array}{ll}\mathbf{Q} & 3000 \\
\mathbf{Q} & 3002 \\
\mathbf{Q} & 3003 \\
\mathbf{Q} & 3012 \\
\mathbf{Q} & 3014\end{array}$ & $\begin{array}{l}404413 \\
404610 \\
404515 \\
404310 \\
404310\end{array}$ & $\begin{array}{l}734701 \\
734621 \\
734231 \\
734359 \\
734700\end{array}$ & $\begin{array}{r}70 \\
70 \\
140 \\
84 \\
110\end{array}$ & $\begin{array}{r}-209 \\
-47 \\
-183 \\
-42 \\
-227\end{array}$ & & & $\begin{array}{r}-66 \\
1 \\
21 \\
-20 \\
-37\end{array}$ & -200 & & & & \\
\hline $\begin{array}{ll}\mathbf{Q} & 3020 \\
\mathbf{Q} & 3026 \\
\mathbf{Q} & 3029 \\
\mathbf{Q} & 3030 \\
\mathbf{Q} & 3036\end{array}$ & $\begin{array}{l}404340 \\
404237 \\
404059 \\
404356 \\
404354\end{array}$ & $\begin{array}{l}734231 \\
734554 \\
734508 \\
735151 \\
735200\end{array}$ & $\begin{array}{l}95 \\
60 \\
25 \\
18 \\
20\end{array}$ & $\begin{array}{r}0 \\
-275 \\
-410 \\
-320 \\
-279\end{array}$ & & & $\begin{array}{r}-85 \\
-44 \\
-42 \\
\text { PRES }\end{array}$ & $\begin{array}{r}-257 \\
-401 \\
-68 \\
-40\end{array}$ & $\begin{array}{l}-235 \\
-225\end{array}$ & -288 & $\begin{array}{l}Q 3034 \\
Q 3062 \\
Q 3036\end{array}$ & \\
\hline $\begin{array}{ll}\mathbf{Q} & 3110 \\
\mathbf{Q} & 3111 \\
\mathbf{Q} & 3112 \\
\mathbf{Q} & \mathbf{3 1 5 6} \\
\mathbf{Q} & \mathbf{3 1 5 7}\end{array}$ & $\begin{array}{l}403845 \\
403850 \\
403939 \\
404050 \\
404107\end{array}$ & $\begin{array}{l}734757 \\
734648 \\
734728 \\
734755 \\
734805\end{array}$ & $\begin{array}{l}10 \\
14 \\
11 \\
35 \\
28\end{array}$ & $\begin{array}{l}-461 \\
-486 \\
-418 \\
-278 \\
-259\end{array}$ & $\begin{array}{r}-104 \\
-112 \\
-99 \\
-80 \\
-102\end{array}$ & $\begin{array}{l}-186 \\
-198 \\
-145 \\
-159 \\
-173\end{array}$ & $\begin{array}{l}-346 \\
-295 \\
-293 \\
-244\end{array}$ & $\begin{array}{l}-431 \\
-447 \\
-381 \\
-278 \\
-257\end{array}$ & & & & \\
\hline $\begin{array}{ll}2 & d_{\text {BNS2 }} \\
2 & \text { BNS3 } \\
2 & \text { BNS4 } \\
2 & \text { BNS5 } \\
2 & \text { BNS7 }\end{array}$ & $\begin{array}{l}404424 \\
404338 \\
404446 \\
404612 \\
404429\end{array}$ & $\begin{array}{l}735610 \\
735414 \\
735406 \\
735233 \\
734632\end{array}$ & $\begin{array}{l}25 \\
29 \\
49 \\
23 \\
61\end{array}$ & $\begin{array}{r}-29 \\
-158 \\
-127 \\
-159 \\
-535\end{array}$ & & & -32 & $\begin{array}{r}-86 \\
\text { PRES } \\
-151\end{array}$ & -302 & $\begin{array}{r}-29 \\
-158 \\
-127 \\
-159 \\
-482\end{array}$ & & \\
\hline $\begin{array}{l}\text { Q BNS9 } \\
\text { OBNS10 } \\
\text { OBNS12 } \\
\text { QBNS13 } \\
\text { QBNS14 }\end{array}$ & $\begin{array}{l}404233 \\
404612 \\
404442 \\
404308 \\
404303\end{array}$ & $\begin{array}{l}734940 \\
734611 \\
734850 \\
735257 \\
734914\end{array}$ & $\begin{array}{r}115 \\
61 \\
16 \\
102 \\
85\end{array}$ & $\begin{array}{l}-537 \\
-411 \\
-406 \\
-296 \\
-490\end{array}$ & -148 & & $\begin{array}{l}-21 \\
-52 \\
-55\end{array}$ & $\begin{array}{l}-99 \\
-86 \\
-254 \\
-185\end{array}$ & $\begin{array}{l}-388 \\
-274 \\
-276 \\
-330\end{array}$ & $\begin{array}{l}-498 \\
-381 \\
-332 \\
-294 \\
-450\end{array}$ & & \\
\hline
\end{tabular}

${ }^{1}$ PRES - Unit present but surface altitude not discernible.

"20ft - "20 foot" clay may be present. 
Table 9.--Hydrogeologic units penetrated by wells and test holes in Kings, Queens, Nassau, Bronx, New York, and Richmond Counties (continued)

[Ẉell locations are shown on pl. 1]

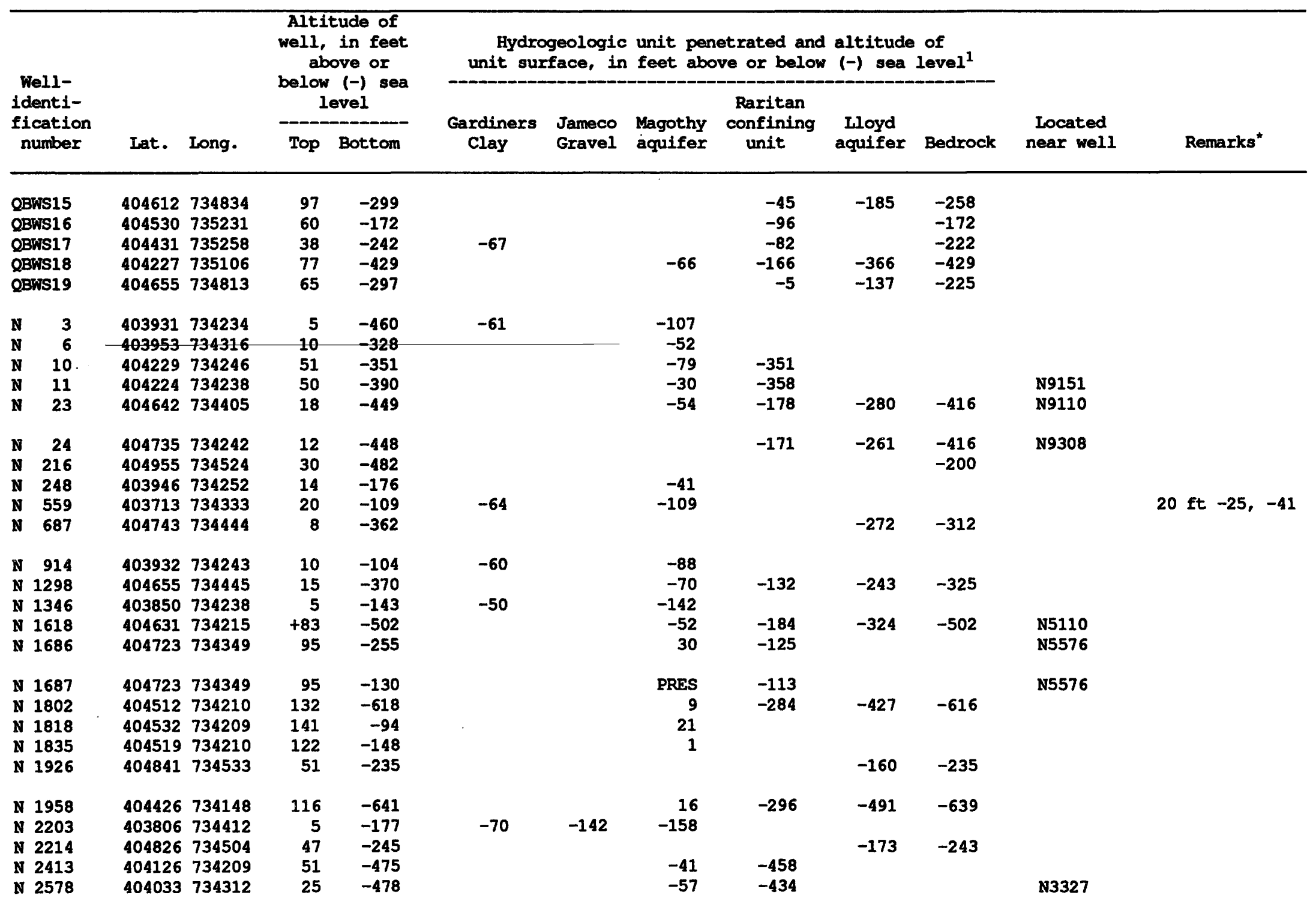

${ }^{1}$ PRES - Unit present but surface altitude not discernible.

"20ft - "20 foot" clay may be present. 
Table 9.-Hydrogeologic units penetrated by wells and test holes in Kings, Queens, Nassau, Bronx, New York, and Richmond Counties (continued)

[Well locations are shown on pl. 1]

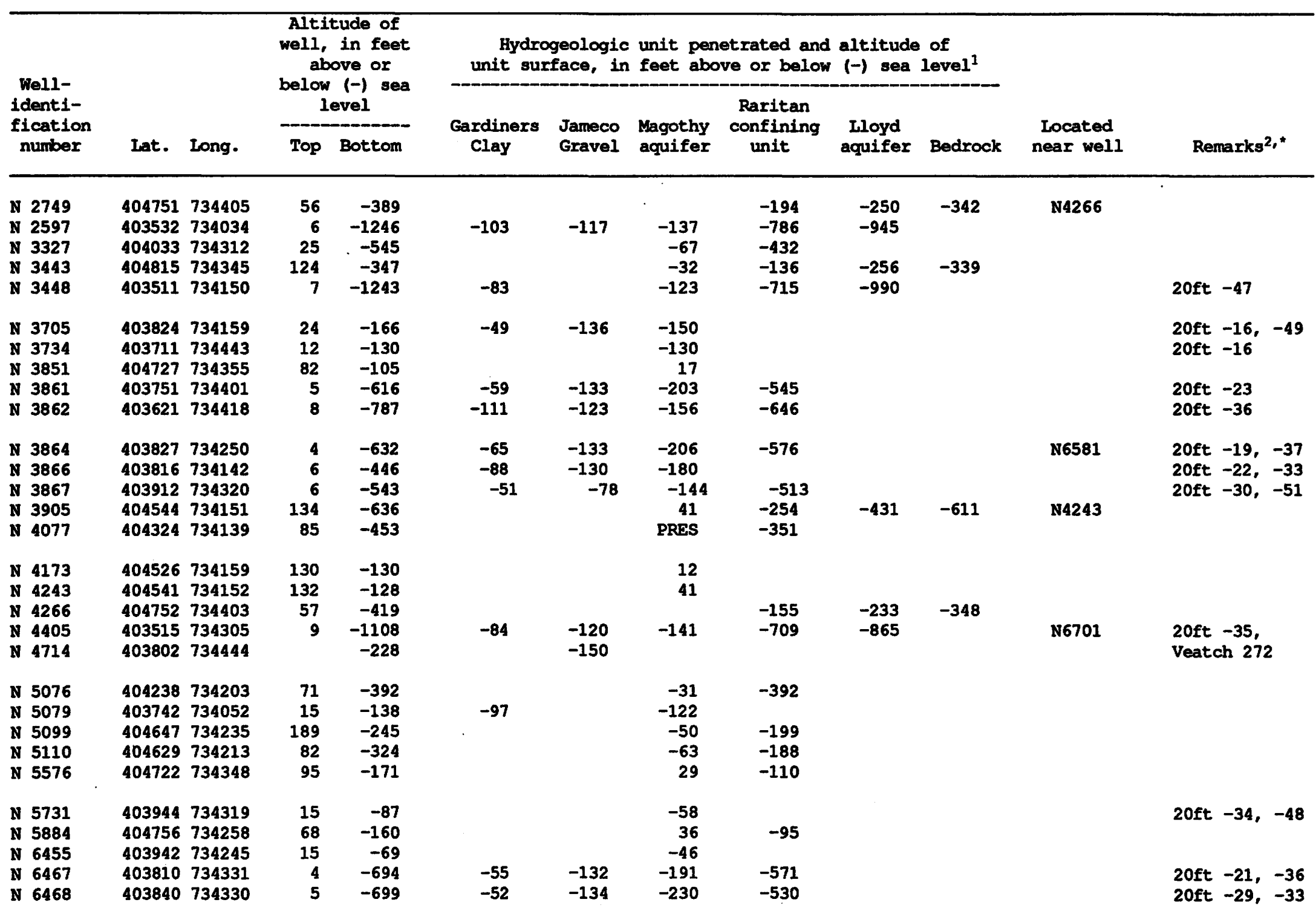


Table 9.--Hydrogeologic units penetrated by wells and test holes in Kings, Queens, Nassau, Bronx, New York, and Richmond Counties (continued)

[Well locations are shown on pl. 1]

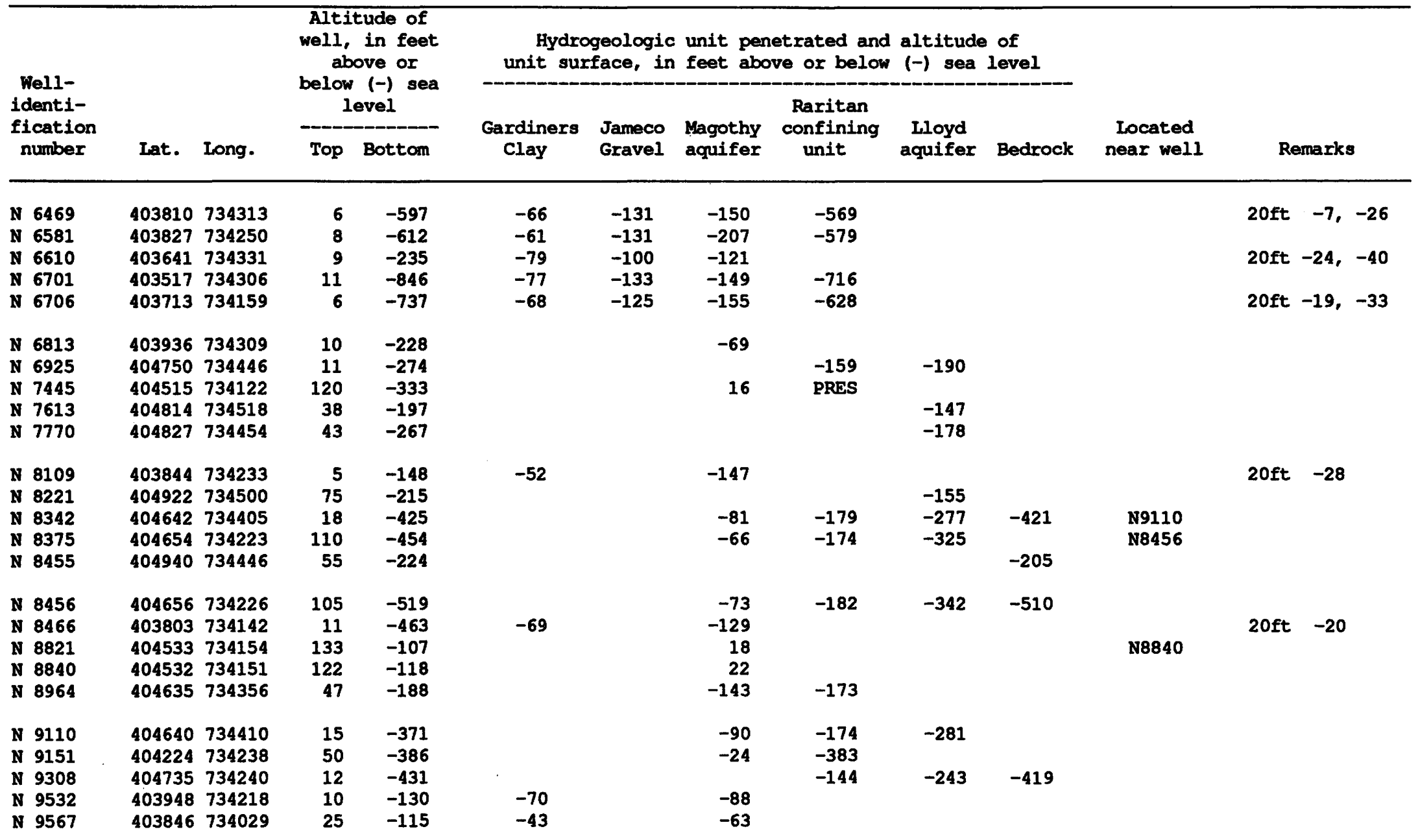

TPRES - Unit present but surface altitude not discernible.

${ }^{2}$ Veatch - Well number from numbering system employed in Veatch and others, 1906.

"20ft - "20 foot" clay may be present. 
Table 10.--Selected chemical analyses of ground water samples from observation wells in Kings, Queens, and eastern Nassau Counties, 1 N.Y. $\mu \mathrm{S} / \mathrm{cm}$, microsiemens per centimeter at 25 degrees celsilis; mg/L, milligrams per liter; $\mu \mathrm{g} / \mathrm{L}$, micrograms per liter;

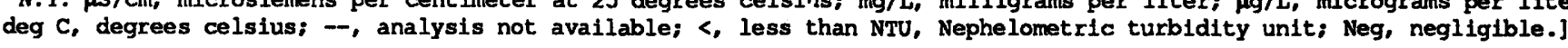

\begin{tabular}{|c|c|c|c|c|c|c|c|c|c|c|c|c|c|c|}
\hline $\begin{array}{c}\text { Well } \\
\text { no }\end{array}$ & Lat & Long & $\begin{array}{l}\text { Scre } \\
\text { Inte } \\
\text { (ft } \\
\text { or } k \\
\text { sea }\end{array}$ & $\begin{array}{l}\text { eened } \\
\text { erval } \\
\text { above } \\
\text { below (-) } \\
\text { level) }\end{array}$ & Aquifer ${ }^{1}$ & $\begin{array}{l}\text { Date } \\
\text { sampled }\end{array}$ & $\begin{array}{l}\text { Spe- } \\
\text { cefic } \\
\text { conduct- } \\
\text { ance } \\
(\mu \mathrm{s} / \mathrm{cm})\end{array}$ & $\underset{\text { (units) }}{\mathrm{pH}}$ & $\begin{array}{l}\text { Fleld } \\
\text { temp } \\
\text { (deg C) }\end{array}$ & $\begin{array}{l}\text { Color } \\
\text { (unit) }\end{array}$ & $\begin{array}{l}\text { Tur- } \\
\text { bIdity } \\
\text { (NTU) }\end{array}$ & $\begin{array}{l}\text { Hard- } \\
\text { ness } \\
\text { (mg/L } \\
\text { as } \\
\mathrm{CaCO}_{3} \text { ) }\end{array}$ & $\begin{array}{l}\text { Calcium, } \\
\text { total } \\
\text { (mg/L } \\
\text { as Ca) }\end{array}$ & $\begin{array}{l}\text { Magne- } \\
\text { stum, } \\
\text { total } \\
\text { mg/L } \\
\text { as } \mathrm{Mg} \text { ) }\end{array}$ \\
\hline K922 & 403919 & 740027 & -117 & to -138 & Jameco & $6 / 14 / 83$ & 1,370 & 7.6 & 12 & 4 & 0.4 & 380 & 97 & 46 \\
\hline \multirow[t]{2}{*}{ K1189 } & 403918 & 740043 & -119 & to -140 & Jameco & $3 / 11 / 81$ & 1,400 & 7.7 & 15 & 6 & 2.0 & 280 & 60 & 31 \\
\hline & & & & & & $6 / 14 / 83$ & 1,470 . & 7.6 & 15 & 60 & 5.9 & 340 & 88 & 42 \\
\hline \multirow[t]{2}{*}{ K1673 } & 403849 & 735852 & -14 & to -19 & Upglac & $2 / 18 / 81$ & 890 & 7.3 & 15.5 & 2 & .3 & 400 & -- & -- \\
\hline & & & & & & $9 / 19 / 83$ & 611 & 7.1 & 15.5 & -- & .3 & 360 & 90 & 22 \\
\hline \multirow[t]{2}{*}{ K1678 } & 403549 & 735701 & -99 & to -109 & Upglac & $4 / 7 / 81$ & 4,560 & 7.6 & 13 & 220 & $>25$ & 880 & 300 & 32 \\
\hline & & & & & & $8 / 3 / 83$ & 3,690 & 7.7 & 16 & 10 & .9 & 740 & 120 & 74 \\
\hline \multirow[t]{2}{*}{ K1689 } & 403742 & 735839 & -18 & to -26 & Upglac & $2 / 25 / 81$ & 860 & 7.3 & 19.5 & 3 & .3 & 96 & - & 50 \\
\hline & & & & & & $9 / 6 / 83$ & 164 & 7.0 & - & 5 & .3 & 340 & 53 & 52 \\
\hline \multirow[t]{2}{*}{$\times 2040$} & 404146 & 735713 & -66 & to -77 & Upglac & $4 / 9 / 81$ & 490 & 7.3 & 15 & 18 & 5.3 & 170 & 29 & 24 \\
\hline & & & & & & $6 / 14 / 83$ & 920 & 7.1 & 15 & 5 & .4 & 390 & 110 & 35 \\
\hline \multirow[t]{2}{*}{ K2407 } & 403524 & 735834 & -19 & to -45 & Upglac & $2 / 12 / 81$ & 1,210 & 6.9 & 7 & 4 & .4 & 160 & -- & -- \\
\hline & & & & & & $8 / 25 / 83$ & 1,600 & 6.6 & 17 & 9 & .8 & 160 & 98 & 70 \\
\hline \multirow[t]{2}{*}{ K2412 } & 403643 & 740131 & -42 & to -53 & Upglac & $4 / 28 / 81$ & 600 & 7.6 & 15 & 3 & 1.2 & 290 & 77 & 24 \\
\hline & & & & & & $8 / 9 / 83$ & 610 & 7.4 & 15 & -- & -- & 300 & 90 & 19 \\
\hline \multirow[t]{2}{*}{ K2482 } & 403945 & 735742 & -35 & to -50 & Upglac & $3 / 19 / 81$ & 720 & 7.4 & 14 & 7 & .4 & 280 & 62 & 30 \\
\hline & & & & & & $8 / 11 / 83$ & 726 & 7.6 & 17 & 4 & .4 & 290 & 50 & 34 \\
\hline \multirow[t]{2}{*}{$\mathrm{K} 2510$} & 403426 & 735832 & -173 & to -199 & Jameco & $3 / 23 / 81$ & $>8,000$ & 7.2 & 13 & 5 & 2.1 & 5,200 & 320 & 1,100 \\
\hline & & & & & & $6 / 22 / 83$ & $>9,000$ & 7.2 & 13 & 12 & 3.6 & 5,300 & 320 & 980 \\
\hline K2511 & 403427 & 735833 & -159 & to -185 & Jameco & $6 / 22 / 83$ & $>9,000$ & 7.3 & -- & 11 & 2 & 5,700 & 350 & 1,200 \\
\hline K2582 & 403732 & 735737 & -153 & to -184 & Jameco & $9 / 22 / 83$ & 980 & 7.8 & 18 & 8 & .6 & 340 & 65 & 49 \\
\hline
\end{tabular}

\begin{tabular}{lll}
\hline & Upglac & upper glactal aquifer \\
Jameco & Jameco aquifer \\
Lloyd & Lloyd aquifer \\
Mag & Magothy aquifer \\
Rar & Raritan confining unit
\end{tabular}

2 Rar Raritan confining unit

were sampled by the U.S Geological Survey and ranged from 2 to 32 inches in diameter Generally, the smaller diameter wells are Geological Survey observation wells; those of larger diameter are industrial or abandoned public-supply wells. Sample-collection procedures were determined mainly by well diameter and depth to water. Normally, where the depth to water was $25 \mathrm{ft}$ or less, a centrifugal pump was used; otherwise a submersible pump was used. In places where both centrifugal and submersible pumps were 1mpractical, the samples were bailed. The volume of water standing in the well casing was evacuated at least three times, and specific conductance was monitored until stable before sampling was begun.

All samples were stored and preserved with approprlate chemical reagents as described by the

Bureau of Water Supply Laboratory (New York City Department of Environmental Protection, written commun.. 1983). Samples were analyzed by the Bureau of Water Supply Laboratory according to methods prescribed by the American Public Health Association (1976). 
Table 10.--Selected chemical analyses of ground water sampled from observation wells in Kings, Queens, and eastern Nassau Counties (continued)

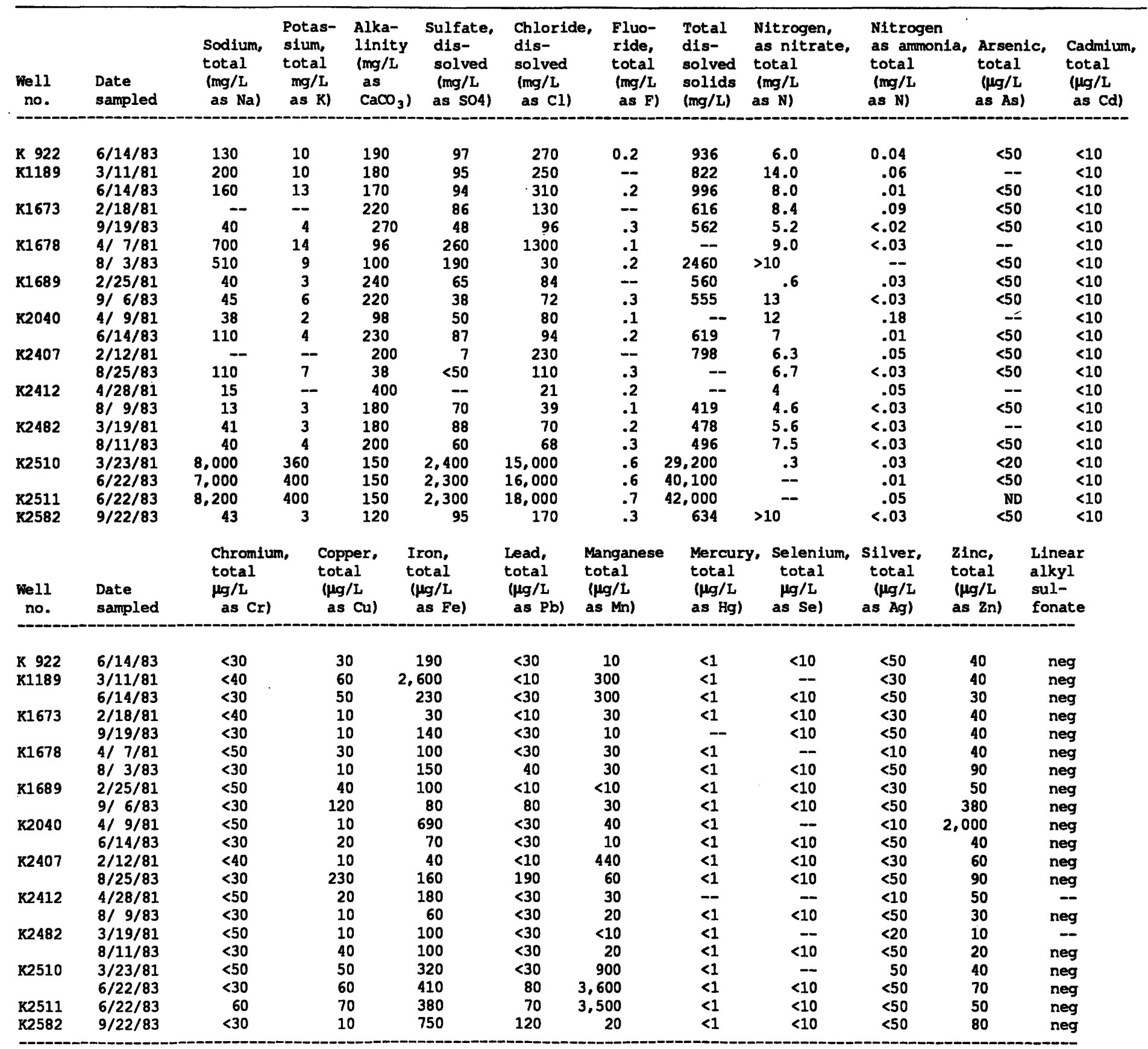


Table 10.--Selected chemical analyses of ground water sampled from observation wells in Kings, Queens, and eastem Nassau Counties (continusd)

\begin{tabular}{|c|c|c|c|c|c|c|c|c|c|c|c|c|c|c|}
\hline $\begin{array}{l}\text { Well } \\
\text { no. }\end{array}$ & Lat & Long & $\begin{array}{l}\text { Scre } \\
\text { int } \\
\text { lft } \\
\text { or } \\
\text { sea }\end{array}$ & $\begin{array}{l}\text { eened } \\
\text { erval } \\
\text { above } \\
\text { below (-) } \\
\text { level) }\end{array}$ & Aqual fer ${ }^{1}$ & $\begin{array}{l}\text { Date } \\
\text { sampled }\end{array}$ & $\begin{array}{l}\text { Spe } \\
\text { cific } \\
\text { conduct- } \\
\text { ance } \\
(\mu \mathrm{s} / \mathrm{cm})\end{array}$ & $-\underset{c}{\mathrm{pH}}$ & $\begin{array}{l}\text { Field } \\
\text { termp } \\
\text { (deg }\end{array}$ & $\begin{array}{l}\text { Color } \\
\text { (unit) }\end{array}$ & $\begin{array}{lr} & \mathrm{Ha} \\
\text { Tur- } & \mathrm{ne} \\
\text { bidity } & \mathrm{g} \\
\text { (NTU) } & \mathrm{C}\end{array}$ & $\begin{array}{ll}\text { Hard- } & \\
\text { ness } & \mathrm{Ca} \\
(\mathrm{mg} / \mathrm{L} & \text { to } \\
\mathrm{as} & (\mathrm{m} \\
\left.\mathrm{CaCO}_{3}\right) & \text { a: }\end{array}$ & $\begin{array}{l}\text { Calcium, } \\
\text { total } \\
\text { (mg/L } \\
\text { as Ca) }\end{array}$ & $\begin{array}{l}\text { Magne- } \\
\text { sium, } \\
\text { total } \\
\mathrm{mg} / \mathrm{L} \\
\text { as } \mathrm{Mg} \text { ) }\end{array}$ \\
\hline K2591 & 404301 & 735753 & -22 & to -37 & Upglac & $\begin{array}{l}4 / 13 / 81 \\
9 / 20 / 83\end{array}$ & $\begin{array}{l}1,400 \\
1,200\end{array}$ & $\begin{array}{l}6.7 \\
6.6\end{array}$ & $\begin{array}{l}17 \\
17.5\end{array}$ & $\begin{array}{r}6 \\
300\end{array}$ & $>25^{18}$ & $\begin{array}{l}410 \\
350\end{array}$ & $\begin{array}{r}100 \\
28\end{array}$ & $\begin{array}{l}36 \\
18\end{array}$ \\
\hline K2598 & 404230 & 735537 & -37 & to -48 & Upglac & $\begin{array}{l}3 / 31 / 81 \\
7 / 13 / 83\end{array}$ & $\begin{array}{r}1,030 \\
750\end{array}$ & $\begin{array}{l}7.2 \\
7.0\end{array}$ & $\begin{array}{l}16 \\
16\end{array}$ & $\begin{array}{l}23 \\
60\end{array}$ & $>20^{.3}$ & $\begin{array}{l}400 \\
240\end{array}$ & $\begin{array}{r}110 \\
65\end{array}$ & $\begin{array}{l}33 \\
19\end{array}$ \\
\hline K2610 & 403938 & 735237 & -35 & to -52 & Upglac & $\begin{array}{l}2 / 12 / 81 \\
6 / 8 / 83\end{array}$ & $\begin{array}{l}4,300 \\
4,000\end{array}$ & $\begin{array}{l}6.9 \\
6.5\end{array}$ & $\begin{array}{l}16 \\
14.5\end{array}$ & $\begin{array}{l}6 \\
6\end{array}$ & $\begin{array}{l}.6 \\
.2\end{array}$ & $\begin{array}{r}1,100 \\
470\end{array}$ & $\overline{180}$ & $\overline{10}$ \\
\hline K2622 & 404028 & 735354 & -40 & to -50 & Upglac & $\begin{array}{l}4 / 7 / 81 \\
9 / 15 / 83\end{array}$ & $\begin{array}{r}650 \\
1,250\end{array}$ & $\begin{array}{l}6.9 \\
7.1\end{array}$ & $\begin{array}{l}11.5 \\
14\end{array}$ & $\begin{array}{l}5 \\
5\end{array}$ & $\begin{array}{r}1.5 \\
.6\end{array}$ & $\begin{array}{l}270 \\
480\end{array}$ & $\begin{array}{r}29 \\
140\end{array}$ & $\begin{array}{l}22 \\
58\end{array}$ \\
\hline K2859 & 403451 & 735856 & -464 & to -480 & Lloyd & $\begin{array}{l}3 / 27 / 81 \\
7 / 26 / 83\end{array}$ & $\begin{array}{l}500 \\
280\end{array}$ & $\begin{array}{l}8.0 \\
7.1\end{array}$ & $\begin{array}{l}15 \\
16\end{array}$ & $\begin{array}{l}18 \\
70\end{array}$ & $\begin{array}{l}30 \\
45\end{array}$ & $\begin{array}{l}40 \\
36\end{array}$ & $\begin{array}{l}4.6 \\
3.8\end{array}$ & $\begin{array}{l}6.8 \\
15\end{array}$ \\
\hline K3130 & 403748 & 735721 & -207 & to -258 & - Jameco & $7 / 28 / 83$ & 1,260 & 7.3 & 17 & 2 & .5 & 240 & 120 & 61 \\
\hline $\begin{array}{l}\text { K3132 } \\
\text { K3133 }\end{array}$ & $\begin{array}{l}403750 \\
404158\end{array}$ & $\begin{array}{l}735717 \\
735658\end{array}$ & $\begin{array}{l}-234 \\
-145\end{array}$ & $\begin{array}{l}\text { to }-280 \\
\text { to }-175\end{array}$ & $\begin{array}{l}\text { Jameco } \\
\text { Jameco }\end{array}$ & $\begin{array}{l}7 / 28 / 83 \\
3 / 4 / 81 \\
6 / 29 / 83\end{array}$ & $\begin{array}{r}4,890 \\
1,700 \\
950\end{array}$ & $\begin{array}{l}7.0 \\
7.4 \\
7.6\end{array}$ & $\begin{array}{l}14 \\
12 \\
15\end{array}$ & $\begin{array}{r}65 \\
6 \\
5\end{array}$ & $\begin{array}{l}.6 \\
.4 \\
.6\end{array}$ & $\begin{array}{r}14,000 \\
460 \\
350\end{array}$ & $\begin{array}{r}280 \\
180 \\
76\end{array}$ & $\begin{array}{c}140 \\
4.5 \\
32\end{array}$ \\
\hline K3151 & 403921 & 735450 & -20 & to -70 & Upglac & $9 / 1 / 83$ & 783 & 7.5 & 15 & 8 & .4 & 330 & 85 & 35 \\
\hline K3214 & 403813 & 735654 & -26 & to -49 & Upglac & $7 / 12 / 83$ & 875 & 6.9 & 17 & 2 & .2 & $\begin{array}{r}310 \\
100\end{array}$ & $\begin{array}{r}80 \\
140\end{array}$ & 37 \\
\hline $\begin{array}{l}\text { K3216 } \\
\text { K3218 }\end{array}$ & $\begin{array}{l}403755 \\
403824\end{array}$ & $\begin{array}{l}735652 \\
735656\end{array}$ & $\begin{array}{l}-24 \\
-23\end{array}$ & $\begin{array}{l}\text { to }-47 \\
\text { to }-46\end{array}$ & $\begin{array}{l}\text { Upglac } \\
\text { Upglac }\end{array}$ & $\begin{array}{l}7 / 12 / 83 \\
4 / 14 / 81\end{array}$ & $\begin{array}{r}2,600 \\
780\end{array}$ & $\begin{array}{l}7.2 \\
7.4\end{array}$ & $\begin{array}{l}15 \\
16.5\end{array}$ & $\begin{array}{l}8 \\
4\end{array}$ & $\begin{array}{r}.4 \\
.3\end{array}$ & $\begin{array}{r}1,200 \\
300\end{array}$ & $\begin{array}{r}140 \\
65\end{array}$ & $\begin{array}{l}70 \\
34\end{array}$ \\
\hline $\begin{array}{l}\text { K3242 } \\
\text { K3245 }\end{array}$ & $\begin{array}{l}403608 \\
404155\end{array}$ & $\begin{array}{l}735757 \\
735521\end{array}$ & $\begin{array}{r}-33 \\
+9\end{array}$ & $\begin{array}{l}\text { to }-53 \\
\text { to }+6\end{array}$ & $\begin{array}{l}\text { Upglac } \\
\text { Upglac }\end{array}$ & $\begin{array}{l}7 / 12 / 83 \\
9 / 20 / 83 \\
2 / 25 / 81\end{array}$ & $\begin{array}{r}800 \\
573 \\
1,000\end{array}$ & $\begin{array}{l}7.1 \\
6.5 \\
6.9\end{array}$ & $\begin{array}{l}17 \\
17 \\
--\end{array}$ & $\begin{array}{r}7 \\
5 \\
40\end{array}$ & $\begin{array}{r}2.4 \\
19^{.2}\end{array}$ & $\begin{array}{l}290 \\
190 \\
190\end{array}$ & $\begin{array}{r}48 \\
100 \\
--\end{array}$ & $\begin{array}{l}36 \\
13 \\
--\end{array}$ \\
\hline $\begin{array}{l}\text { Well } \\
\text { no }\end{array}$ & $\begin{array}{l}\text { Date } \\
\text { sampled }\end{array}$ & & $\begin{array}{l}\text { Sodium, } \\
\text { total } \\
\text { (mg/L } \\
\text { as Na) }\end{array}$ & $\begin{array}{l}\text { Potas- } \\
\text { stum, } \\
\text { total } \\
\text { mg/L } \\
\text { as } \mathrm{K} \text { ) }\end{array}$ & $\begin{array}{l}\text { Alka- } \\
\text { linity } \\
\text { (mg/L } \\
\text { as } \\
\mathrm{CaCO}_{3} \text { ) }\end{array}$ & $\begin{array}{l}\text { Sulfate, } \\
\text { dis- } \\
\text { solved } \\
\text { (mg/L } \\
\text { as SO4) }\end{array}$ & $\begin{array}{l}\text { Chloride, } \\
\text { dis- } \\
\text { solved } \\
\text { (mg/L } \\
\text { as } \mathrm{Cl} \text { ) }\end{array}$ & $\begin{array}{l}\text { Fluo- } \\
\text { ride, } \\
\text { total } \\
\text { (mg/L } \\
\text { as F) }\end{array}$ & $\begin{array}{l}\text { Total } \\
\text { dis- } \\
\text { solved } \\
\text { solids } \\
\text { (mg/L) }\end{array}$ & $\begin{array}{l}\text { Nitrogen, } \\
\text { as nitrate, } \\
\text { total } \\
\text { (mg/L } \\
\text { as } \mathrm{N} \text { ) }\end{array}$ & $\begin{array}{l}\text { Nitrogen } \\
\text { as anmonia, } \\
\text { total } \\
\text { (mg/L } \\
\text { as N) }\end{array}$ & $\begin{array}{l}\text { Arsenic, } \\
\text { total } \\
\text { ( } \mu g / L \\
\text { as As) }\end{array}$ & $\begin{array}{c}\text { c. Cadmium } \\
\text { total } \\
(\mu g / L \\
\text { as Cd) }\end{array}$ & \\
\hline K2591 & $4 / 13 / 8$ & & 150 & 12 & 190 & 90 & 250 & 0.2 & -- & 6.7 & 0.01 & - & $<10$ & \\
\hline & $9 / 20 / 8$ & & 29 & 5 & 150 & 190 & 210 & .4 & 805 & 10 & $<.03$ & $<50$ & $<10$ & \\
\hline K2598 & $\begin{array}{l}3 / 31 / 8 \\
7 / 13 / 8\end{array}$ & & $\begin{array}{l}62 \\
62\end{array}$ & $\begin{array}{l}4 \\
7\end{array}$ & $\begin{array}{r}210 \\
44\end{array}$ & $\begin{array}{r}130 \\
97\end{array}$ & $\begin{array}{l}100 \\
250\end{array}$ & $\begin{array}{l}.1 \\
.3\end{array}$ & $\begin{array}{l}508 \\
535\end{array}$ & $\begin{array}{r}16 \\
>10\end{array}$ & $\begin{array}{l}.12 \\
.03\end{array}$ & $\begin{array}{l}<1 \\
<50\end{array}$ & $\begin{array}{l}<10 \\
<10\end{array}$ & \\
\hline K2610 & $\begin{array}{l}2 / 12 / 8 \\
6 / 8 / 8\end{array}$ & & 340 & $\overline{13}$ & $\begin{array}{l}200 \\
230\end{array}$ & $\begin{array}{l}98 \\
--\end{array}$ & $\begin{array}{r}1,300 \\
500\end{array}$ & -- & $\begin{array}{l}3,320 \\
2,700\end{array}$ & $\begin{array}{l}8.7 \\
9.2\end{array}$ & $\begin{array}{l}.03 \\
.11\end{array}$ & $\begin{array}{l}<50 \\
<50\end{array}$ & $\begin{array}{l}<10 \\
<10\end{array}$ & \\
\hline K2622 & $\begin{array}{l}4 / 7 / 8 \\
9 / 15 / 8\end{array}$ & & $\begin{array}{l}20 \\
94\end{array}$ & $\begin{array}{l}1 \\
5\end{array}$ & $\begin{array}{r}96 \\
250\end{array}$ & $\begin{array}{l}85 \\
82\end{array}$ & $\begin{array}{r}95 \\
210\end{array}$ & $\begin{array}{l}.2 \\
.4\end{array}$ & $8 \overline{84}$ & $\begin{array}{l}7.5 \\
6.4\end{array}$ & $\begin{array}{l}<.03 \\
<.03\end{array}$ & $<50$ & $\begin{array}{l}<10 \\
<10\end{array}$ & \\
\hline K2859 & $\begin{array}{l}3 / 27 / 8 \\
7 / 26 / 8\end{array}$ & & $\begin{array}{l}70 \\
45\end{array}$ & $\begin{array}{l}6 \\
5\end{array}$ & $\begin{array}{l}52 \\
44\end{array}$ & $\begin{array}{l}10 \\
21\end{array}$ & $\begin{array}{r}110 \\
52\end{array}$ & .4 & $\begin{array}{l}260 \\
193\end{array}$ & $\begin{array}{l}.3 \\
.24\end{array}$ & $\begin{array}{l}.03 \\
.03\end{array}$ & $<\overline{0}$ & $\begin{array}{l}<10 \\
<10\end{array}$ & \\
\hline K3130 & $\begin{array}{l}7 / 28 / 8 \\
7 / 28 / 8\end{array}$ & & $\begin{array}{r}70 \\
480\end{array}$ & $\begin{array}{r}3 \\
12\end{array}$ & $\begin{array}{l}120 \\
100\end{array}$ & $\begin{array}{r}78 \\
180\end{array}$ & $\begin{array}{l}290 \\
500\end{array}$ & $\begin{array}{l}.2 \\
.1\end{array}$ & $\begin{array}{r}866 \\
3,470\end{array}$ & $\begin{array}{l}5 \\
.24\end{array}$ & $\begin{array}{l}<.03 \\
<.03\end{array}$ & $\begin{array}{l}<50 \\
<50\end{array}$ & $\begin{array}{l}<10 \\
<10\end{array}$ & \\
\hline K3133 & $\begin{array}{l}3 / 4 / 8 \\
6 / 29 / 8\end{array}$ & & $\begin{array}{r}180 \\
71\end{array}$ & 4 & $\begin{array}{l}180 \\
180\end{array}$ & $\begin{array}{r}130 \\
1\end{array}$ & $\begin{array}{l}340 \\
140\end{array}$ & $-\overline{-}$ & $\begin{array}{l}455 \\
707\end{array}$ & $\begin{array}{l}2.6 \\
1.4\end{array}$ & $\begin{array}{l}.21 \\
.02\end{array}$ & $\begin{array}{l}<50 \\
<50\end{array}$ & $\begin{array}{l}<10 \\
<10\end{array}$ & \\
\hline K3151 & $9 / 1 / 8$ & & 26 & 5 & 160 & $<50$ & 73 & .2 & - & 11 & - & $<50$ & $<10$ & \\
\hline K3214 & $7 / 12 / 8$ & & 55 & 6 & 120 & -- & 51 & .2 & 612 & $>10$ & .03 & $<50$ & $<10$ & \\
\hline K3216 & $7 / 12 / 8$ & & 160 & 10 & 110 & -- & 1,100 & .2 & 1,640 & $>10$ & .03 & $<50$ & $<10$ & \\
\hline K3218 & $4 / 14 / 8$ & & 38 & 3 & 140 & 57 & 93 & .1 & $\overline{-}$ & 15 & .01 & -- & $<10$ & \\
\hline & $7 / 12 / 8$ & & 50 & 5 & 120 & $=-$ & 120 & .2 & 565 & $>10$ & .03 & $<50$ & $<10$ & \\
\hline K3242 & $9 / 20 / 8$ & & 107 & 4 & 94 & 85 & 40 & .8 & 348 & .85 & $<.03$ & $<50$ & $<10$ & \\
\hline K3245 & $2 / 25 / 8$ & & -- & - & 80 & 160 & 160 & -- & 615 & 10 & .12 & $<50$ & $<10$ & \\
\hline
\end{tabular}


Table 10.--Selected chemical analyses of ground water sampled from observation wells in Kings, Queens, and eastern Nassau Counties (continued)

\begin{tabular}{|c|c|c|c|c|c|c|c|c|c|c|c|}
\hline $\begin{array}{l}\text { Well } \\
\text { no. }\end{array}$ & $\begin{array}{l}\text { Date } \\
\text { sampled }\end{array}$ & $\begin{array}{l}\text { Chromium, } \\
\text { total } \\
\mu g / L \\
\text { as } \mathrm{Cr})\end{array}$ & $\begin{array}{l}\text { Copper, } \\
\text { total } \\
(\mu g / L \\
\text { as } \mathrm{Cu})\end{array}$ & $\begin{array}{l}\text { Iron, } \\
\text { total } \\
\text { ( } \mu g / 1 \\
\text { as Fe) }\end{array}$ & $\begin{array}{l}\text { Lead, } \\
\text { total } \\
(\mu g / L \\
\text { as } \mathrm{Pb})\end{array}$ & $\begin{array}{l}\text { Manganese } \\
\text { total } \\
(\mu \mathrm{g} / \mathrm{L} \\
\text { as } \mathrm{Mn})\end{array}$ & $\begin{array}{l}\text { Mercury, } \\
\text { total } \\
(\mu g / L \\
\text { as } \mathrm{Hg})\end{array}$ & $\begin{array}{l}\text { Selentum, } \\
\text { total } \\
\mu \mathrm{g} / \mathrm{L} \\
\text { as Se) }\end{array}$ & $\begin{array}{l}\text { Silver, } \\
\text { total } \\
\text { ( } \mu g / L \\
\text { as } \mathrm{Ag})\end{array}$ & $\begin{array}{l}\text { Zinc, } \\
\text { total } \\
\text { ( } \mu \mathrm{g} / \mathrm{L} \\
\text { as } \mathrm{Zn})\end{array}$ & $\begin{array}{l}\text { Linear } \\
\text { alkyl } \\
\text { sul- } \\
\text { fonate }\end{array}$ \\
\hline \multirow{2}{*}{ K2591 } & $4 / 13 / 81$ & 350 & 50 & 6,100 & $<30$ & 1,900 & $<1$ & -- & $<10$ & 30 & neg \\
\hline & $9 / 20 / 83$ & $<30$ & 30 & 200 & $<30$ & 180 & -- & $<10$ & $<50$ & 80 & neg \\
\hline \multirow[t]{2}{*}{ K2598 } & $3 / 31 / 81$ & 600 & 10 & 60 & $<10$ & 30 & $<1$ & -- & $<10$ & 20 & neg \\
\hline & $7 / 13 / 83$ & 1600 & 10 & 120 & $<30$ & 40 & $<1$ & $<10$ & $<50$ & 130 & neg \\
\hline \multirow[t]{2}{*}{ K2610 } & $2 / 12 / 81$ & 150 & 20 & 60 & $<10$ & 160 & $<1$ & $<10$ & $<30$ & 60 & neg \\
\hline & $6 / 8 / 83$ & 140 & 90 & 200 & -- & 130 & 2 & $<10$ & -- & 40 & neg \\
\hline \multirow[t]{2}{*}{ K2622 } & $4 / 7 / 81$ & $<50$ & 10 & 60 & $<30$ & 20 & $<1$ & -- & $<10$ & 20 & neg \\
\hline & $9 / 15 / 83$ & $<30$ & 20 & 70 & $<30$ & 10 & -- & $<10$ & $<50$ & 70 & neg \\
\hline \multirow[t]{2}{*}{ K2859 } & $3 / 27 / 81$ & $<50$ & 10 & 1,700 & $<10$ & 50 & $<1$ & -- & $<10$ & 20 & neg \\
\hline & $7 / 26 / 83$ & $<30$ & 30 & -- & $<30$ & 80 & $<1$ & $<10$ & $<50$ & 70 & neg \\
\hline K3130 & $7 / 28 / 83$ & $<30$ & 20 & 60 & $<30$ & 300 & $<1$ & $<10$ & $<50$ & 50 & neg \\
\hline K3132 & $7 / 28 / 83$ & $<30$ & 10 & 4,300 & $<30$ & 2,300 & $<1$ & $<10$ & $<50$ & 30 & neg \\
\hline \multirow[t]{2}{*}{ K3133 } & $3 / 4 / 81$ & 40 & 50 & 180 & $<10$ & 360 & $<1$ & $<10$ & $<30$ & $<10$ & neg \\
\hline & $6 / 29 / 83$ & $<30$ & 20 & 100 & $<30$ & 300 & $<1$ & $<10$ & $<50$ & 80 & neg \\
\hline K3151 & $9 / 1 / 83$ & $<30$ & 10 & 150 & $<30$ & 50 & $<1$ & $<10$ & $<50$ & 50 & neg \\
\hline K3214 & $7 / 12 / 83$ & $<30$ & 10 & 70 & $<30$ & 50 & $<1$ & $<10$ & $<50$ & 100 & neg \\
\hline K3216 & $7 / 12 / 83$ & $<30$ & 10 & 630 & $<30$ & 120 & $<1$ & $<10$ & $<50$ & 120 & neg \\
\hline \multirow[t]{2}{*}{ K3218 } & $4 / 14 / 81$ & 50 & 20 & 50 & $<30$ & 10 & $<1$ & - & $<10$ & 30 & - \\
\hline & $7 / 12 / 83$ & $<30$ & 30 & 80 & $<30$ & 10 & $<1$ & $<10$ & $<50$ & 170 & neg \\
\hline K3242 & $9 / 20 / 83$ & $<30$ & 630 & 95,000 & $<30$ & 18,000 & -- & $<10$ & $<50$ & 160 & neg \\
\hline K3245 & $2 / 25 / 81$ & $<40$ & 70 & 50,000 & $<10$ & 8,700 & $<1$ & $<10$ & $<30$ & 25,000 & neg \\
\hline
\end{tabular}


Table 10.--Selected chemical analyses of ground water sampled from observation wells in Kings, Queens, and eastern Nassau Counties (continued.

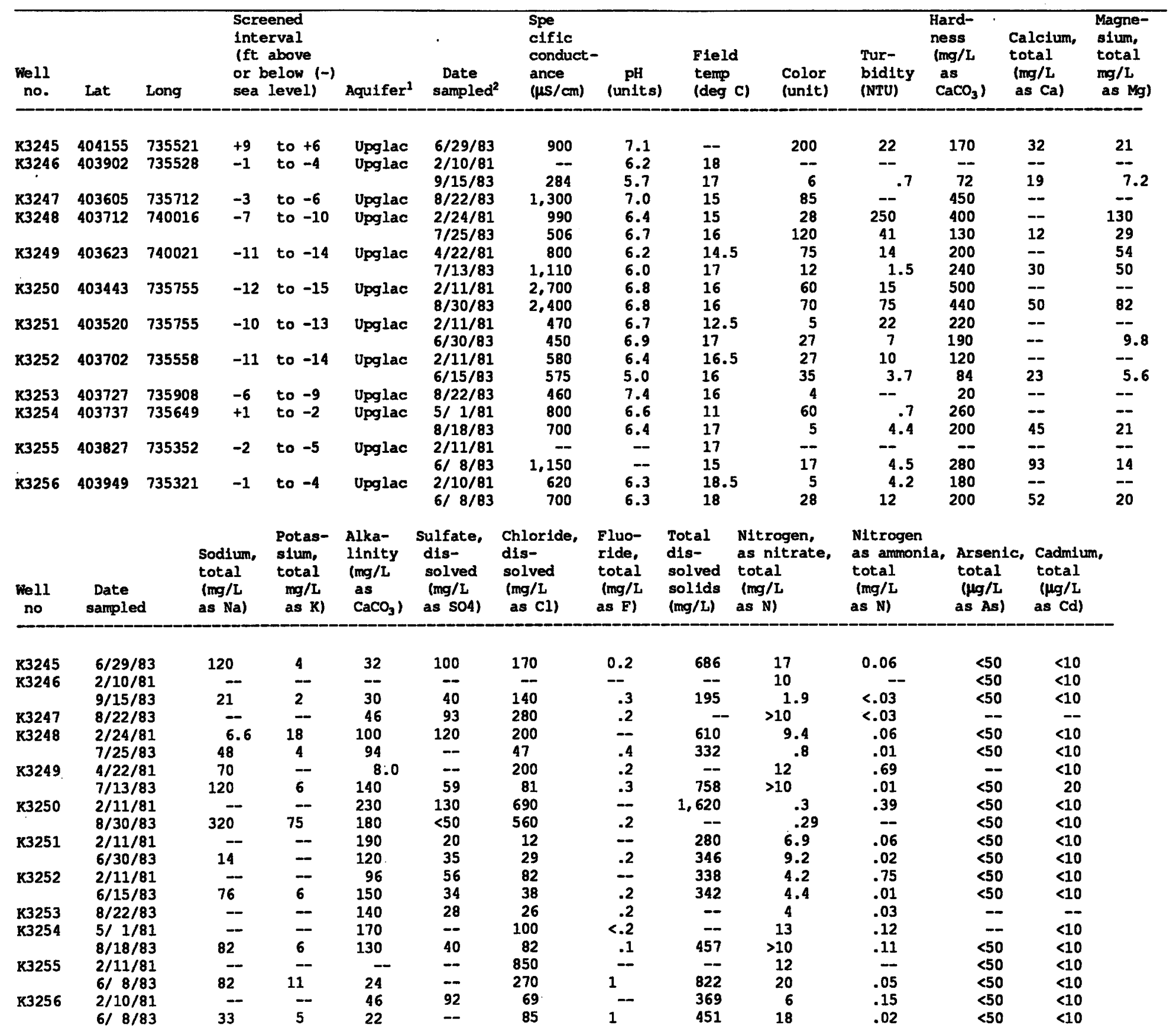


Table 10.--Selected chemical analyses of ground water sampled from observation wells in Kings, Queens, and eastern Nạssau Counties (continued)

\begin{tabular}{|c|c|c|c|c|c|c|c|c|c|c|c|}
\hline $\begin{array}{l}\text { Well } \\
\text { no. }\end{array}$ & $\begin{array}{l}\text { Date } \\
\text { sampled }\end{array}$ & $\begin{array}{l}\text { Chromlum, } \\
\text { total } \\
\mu \mathrm{g} / \mathrm{L} \\
\text { as } \mathrm{Cr})\end{array}$ & $\begin{array}{l}\text { Copper, } \\
\text { total } \\
(\mu g / L \\
\text { as Cu) }\end{array}$ & $\begin{array}{l}\text { Iron, } \\
\text { total } \\
(\mu g / L \\
\text { as } \mathrm{Fe})\end{array}$ & $\begin{array}{l}\text { Lead, } \\
\text { total } \\
(\mu \mathrm{g} / \mathrm{L} \\
\text { as } \mathrm{Pb})\end{array}$ & $\begin{array}{l}\text { Manganese } \\
\text { total } \\
(\mu \mathrm{g} / \mathrm{L} \\
\text { as } \mathrm{Mn})\end{array}$ & $\begin{array}{l}\text { Mercury, } \\
\text { total } \\
\text { ( } \mu g / L \\
\text { as } \mathrm{Hg})\end{array}$ & $\begin{array}{l}\text { Selentum, } \\
\text { total } \\
\mu g / L \\
\text { as Se) }\end{array}$ & $\begin{array}{l}\text { Sllver, } \\
\text { total } \\
\text { ( } \mu g / L \\
\text { as Ag) }\end{array}$ & $\begin{array}{l}\text { Zinc, } \\
\text { total } \\
\text { ( } \mu g / L \\
\text { as } \mathrm{Zn})\end{array}$ & $\begin{array}{l}\text { Linear } \\
\text { alkyl } \\
\text { sul- } \\
\text { fonate }\end{array}$ \\
\hline K3245 & $6 / 29 / 83$ & $<30$ & 600 & 80,000 & 360 & 3,400 & $<1$ & $<10$. & $<50$ & 26,000 & neg \\
\hline \multirow[t]{2}{*}{ K3246 } & $2 / 10 / 81$ & $<40$ & 10 & 600 & $<10$ & 170 & $<1$ & $<10$ & $<30$ & 1,400 & neg \\
\hline & $9 / 15 / 83$ & $<30$ & 10 & 5,900 & $<30$ & 200 & -- & $<10$ & $<50$ & 1,500 & neg \\
\hline K3247 & $8 / 22 / 83$ & - & -- & -- & $<30$ & -- & $<1$ & -- & -- & -- & neg \\
\hline \multirow[t]{2}{*}{ K3248 } & $2 / 24 / 81$ & 50 & 2,500 & 56,000 & $<10$ & 5,300 & $<1$ & $<10$ & $<30$ & 14,000 & neg \\
\hline & $7 / 25 / 83$ & $<30$ & 30 & 12,000 & $<30$ & 250 & $<1$ & $<10$ & $<50$ & 3,500 & neg \\
\hline \multirow[t]{2}{*}{ K3249 } & $4 / 22 / 81$ & $<50$ & 650 & 56,000 & $<30$ & 3,800 & $\overline{-}$ & -- & $<10$ & 110,000 & neg \\
\hline & $7 / 13 / 83$ & 60 & 1,400 & 87,000 & 200 & 1,300 & $<1$ & $<10$ & $<50$ & 38,000 & neg \\
\hline \multirow[t]{2}{*}{ K3250 } & $2 / 11 / 81$ & $<40$ & 10 & 6,700 & $<10$ & 1,300 & $<1$ & $<10$ & $<30$ & 730 & neg \\
\hline & $8 / 30 / 83$ & $<30$ & 10 & 18,000 & 30 & 1,000 & $<1$ & $<10$ & $<50$ & 900 & neg \\
\hline \multirow[t]{2}{*}{ K3251 } & $2 / 11 / 81$ & $<40$ & 20 & 2,100 & $<10$ & 400 & $<1$ & $<10$ & $<30$ & 1,400 & neg \\
\hline & $6 / 30 / 83$ & $<30$ & 20 & 950 & $<30$ & 80 & $<1$ & $<10$ & $<50$ & 850 & neg \\
\hline \multirow[t]{2}{*}{ K3252 } & $2 / 11 / 81$ & $<40$ & 10 & 2,700 & $<10$ & 480 & $<1$ & $<10$ & $<30$ & 1,000 & neg \\
\hline & $6 / 15 / 83$ & $<30$ & 40 & 440 & $<30$ & 330 & $<1$ & $<10$ & $<50$ & 200 & neg \\
\hline K3253 & $8 / 22 / 83$ & - & -- & -- & $<30$ & -- & $<1$ & -- & -- & -- & neg \\
\hline \multirow[t]{2}{*}{ K3254 } & $5 / 1 / 81$ & $<50$ & 90 & 24,000 & $<30$ & -- & -- & -- & - & - & neg \\
\hline & $8 / 18 / 83$ & $<30$ & 30 & 3,400 & $<30$ & 60 & 54 & $<10$ & $<50$ & 3,200 & neg \\
\hline \multirow[t]{2}{*}{ K3255 } & $2 / 11 / 81$ & $<40$ & 10 & 2,100 & $<10$ & 50 & $<1$ & $<10$ & $<30$ & 1,400 & neg \\
\hline & $6 / 8 / 83$ & $<30$ & 40 & 560 & $<30$ & 30 & $<1$ & $<10$ & $<50$ & 170 & neg \\
\hline \multirow{2}{*}{ K3256 } & $2 / 10 / 81$ & $<40$ & 10 & 12,000 & $<10$ & 160 & $<1$ & $<10$ & $<30$ & 2,500 & neg \\
\hline & $6 / 8 / 83$ & $<30$ & 30 & 2,100 & $<30$ & 100 & $<1$ & $<10$ & $<50$ & 1,300 & neg \\
\hline
\end{tabular}


Table 10.--Selected chemical analyses of ground water sampled from observation wells in Kings, Queens, and eastern Nassau Counties (continued)

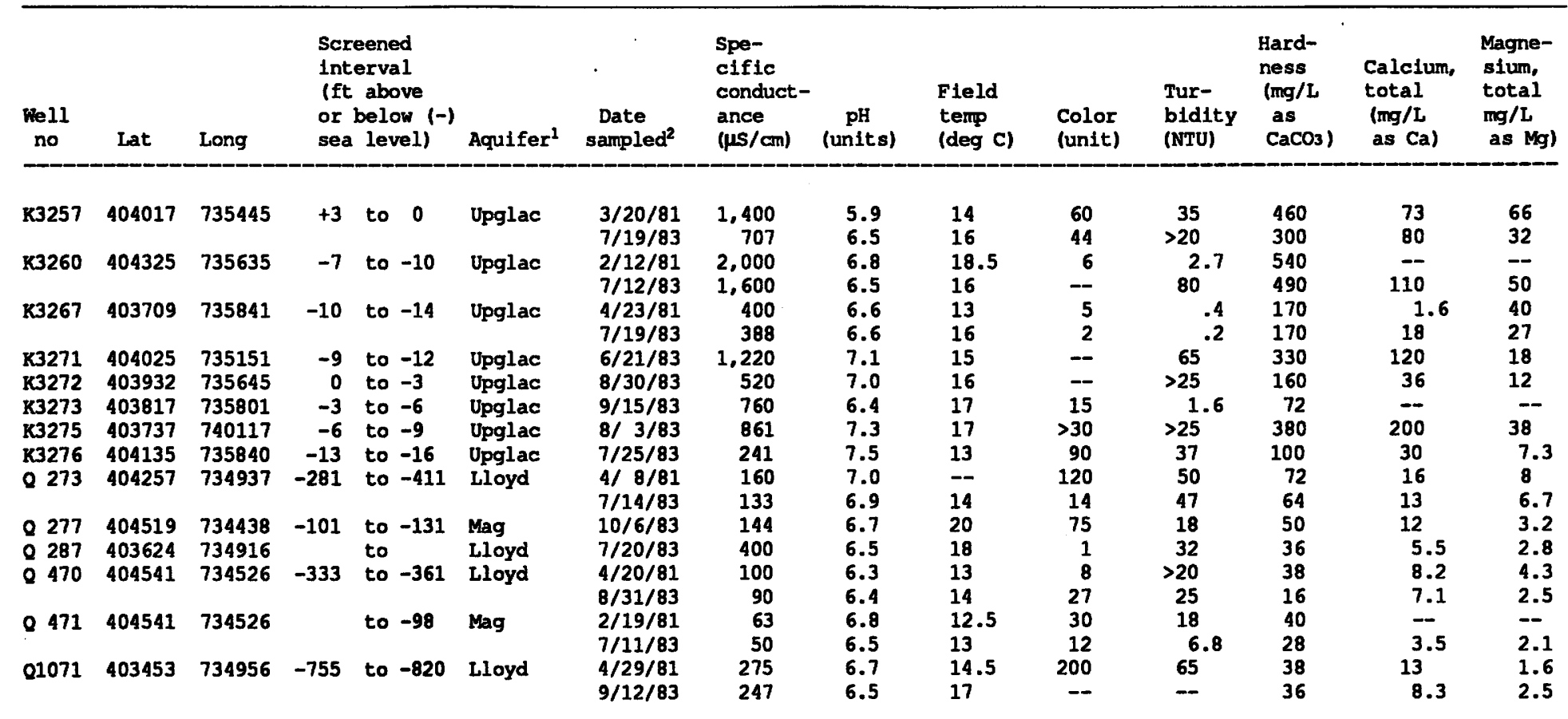

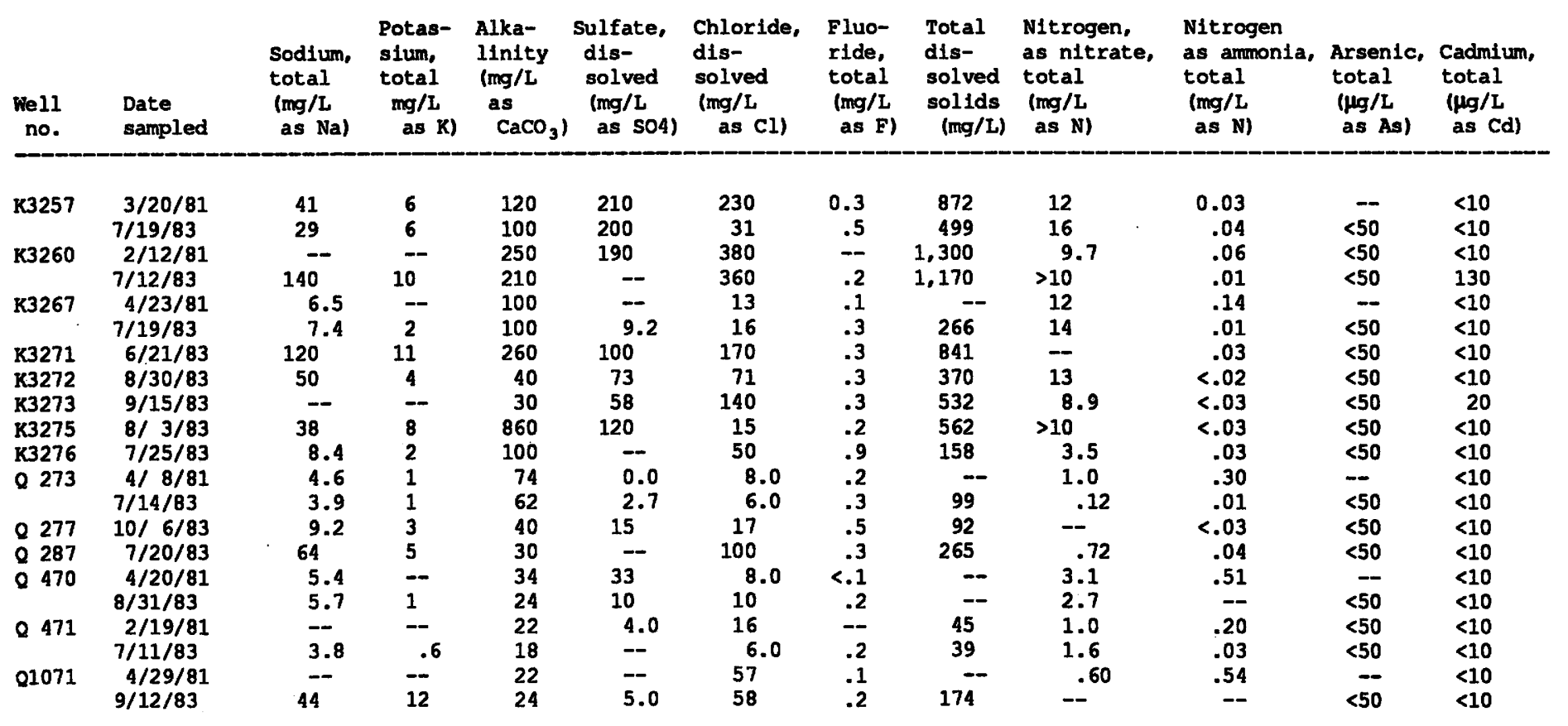


Table 10.--Selected chemical analyses of ground water sampled from observation wells in Kings, Queens, and eastern Nassau Counties (continued)

\begin{tabular}{|c|c|c|c|c|c|c|c|c|c|c|c|}
\hline $\begin{array}{l}\text { Fell } \\
\text { no. }\end{array}$ & $\begin{array}{l}\text { Date } \\
\text { sampled }\end{array}$ & $\begin{array}{l}\text { Chromium, } \\
\text { total } \\
\mu g / L \\
\text { as } \mathrm{Cr} \text { ) }\end{array}$ & $\begin{array}{l}\text { Copper, } \\
\text { total } \\
(\mu g / \mathrm{L} \\
\text { as } \mathrm{Cu})\end{array}$ & $\begin{array}{l}\text { Iron, } \\
\text { total } \\
(\mu g / L \\
\text { as } \mathrm{Fe})\end{array}$ & $\begin{array}{l}\text { Lead, } \\
\text { total } \\
(\mu \mathrm{g} / \mathrm{L} \\
\text { as } \mathrm{Pb})\end{array}$ & $\begin{array}{l}\text { Manganese } \\
\text { total } \\
\text { ( } \mu g / L \\
\text { as } \mathrm{Mn})\end{array}$ & $\begin{array}{l}\text { Mercury, } \\
\text { total } \\
(\mu g / L \\
\text { as } \mathrm{Hg})\end{array}$ & $\begin{array}{l}\text { Selentum, } \\
\text { total } \\
\mu \mathrm{g} / \mathrm{L} \\
\text { as Se) }\end{array}$ & $\begin{array}{l}\text { Silver, } \\
\text { total } \\
(\mu g / L \\
\text { as Ag) }\end{array}$ & $\begin{array}{l}\text { Zinc, } \\
\text { total } \\
(\mu g / L \\
\text { as } \mathrm{Zn})\end{array}$ & $\begin{array}{l}\text { Linear } \\
\text { alkyl } \\
\text { sul- } \\
\text { fonate }\end{array}$ \\
\hline \multirow[t]{2}{*}{ K3257 } & $3 / 20 / 81$ & $<50$ & 360 & 46,000 & 3,000 & 3,800 & $<1$ & -- & $<20$ & 70,000 & neg \\
\hline & $7 / 19 / 83$ & $<30$ & 1,1900 & 84,000 & 700 & 1,500 & $<1$ & $<10$ & $<50$ & 21,000 & neg \\
\hline \multirow[t]{2}{*}{ K3260 } & $2 / 12 / 81$ & $<40$ & 20 & 1,000 & $<10$ & 60 & $<1$ & $<10$ & $<30$ & 1,400 & neg \\
\hline & $7 / 12 / 83$ & $<30$ & 1,200 & 76,000 & 380 & 450 & $<1$ & $<10$ & $<50$ & 12,000 & neg \\
\hline \multirow[t]{2}{*}{ K3267 } & $4 / 23 / 81$ & $<50$ & 30 & 150 & $<30$ & 30 & -- & -- & $<10$ & 1,600 & neg \\
\hline & $7 / 19 / 83$ & $<30$ & 10 & 70 & $<30$ & 10 & $<1$ & $<10$ & $<50$ & 460 & neg \\
\hline K3271 & $6 / 21 / 83$ & $<30$ & 370 & 13,000 & 650 & 1,700 & 1 & $<10$ & $<50$ & 5,500 & neg \\
\hline K3272 & $8 / 30 / 83$ & $<30$ & 2,400 & 18,000 & 1,400 & 550 & - & $<10$ & $<50$ & 9,600 & neg \\
\hline K3273 & $9 / 15 / 83$ & $<30$ & 10 & 1,600 & $<30$ & 230 & -- & $<10$ & $<50$ & 8,800 & neg \\
\hline K3275 & $8 / 3 / 83$ & 100 & 3,300 & 60,000 & 1,200 & 5,400 & $<1$ & $<10$ & $<50$ & 73,000 & neg \\
\hline K3276 & $7 / 25 / 83$ & $<30$ & 2,300 & 10,000 & 300 & 150 & $<1$ & $<10$ & $<50$ & 4,500 & neg \\
\hline \multirow[t]{2}{*}{0273} & $4 / 8 / 81$ & $<50$ & 10 & 4,000 & $<30$ & 400 & $<1$ & -- & $<10$ & 20 & neg \\
\hline & $7 / 14 / 83$ & $<30$ & 10 & 5,500 & $<30$ & 400 & $<1$ & $<10$ & $<50$ & 20 & neg \\
\hline \multirow{4}{*}{$\begin{array}{ll}0 & 277 \\
0 & 287 \\
0 & 470\end{array}$} & $10 / 6 / 83$ & $<30$ & 30 & 1,300 & $<30$ & 140 & $<1$ & $<10$ & $<50$ & 100 & neg \\
\hline & $7 / 20 / 83$ & $<30$ & 10 & 28,000 & 150 & 1,400 & $<1$ & $<10$ & $<50$ & 60 & neg \\
\hline & $4 / 20 / 81$ & $<50$ & 640 & 70,000 & $<30$ & 130 & -- & - & $<10$ & -- & neg \\
\hline & $8 / 31 / 83$ & $<30$ & 80 & 29,000 & 460 & 30 & $<1$ & $<10$ & $<50$ & 3,000 & neg \\
\hline \multirow[t]{2}{*}{ Q 471} & $2 / 19 / 81$ & $<40$ & 20 & 790 & $<10$ & 10 & $<1$ & $<10$ & $<30$ & 120 & neg \\
\hline & $7 / 11 / 83$ & $<30$ & 100 & 570 & 80 & 30 & $<1$ & $<10$ & $<50$ & 70 & neg \\
\hline \multirow[t]{2}{*}{ Q1071 } & $4 / 29 / 81$ & $<50$ & 10 & 11,000 & $<30$ & 350 & - & - & -- & 20 & neg \\
\hline & $9 / 12 / 83$ & $<30$ & 10 & 11,000 & $<30$ & 340 & -- & $<10$ & $<50$ & 30 & neg \\
\hline
\end{tabular}


Table 10.--Selected chemical analyses of ground water sampled from observation wells in Kings, Queens, and eastern Nassau Counties (continued)

\begin{tabular}{|c|c|c|c|c|c|c|c|c|c|c|c|c|c|c|}
\hline $\begin{array}{l}\text { Well } \\
\text { no }\end{array}$ & Lat & Long & $\begin{array}{l}\text { Scree } \\
\text { inter } \\
\text { (ft a } \\
\text { or be } \\
\text { sea I }\end{array}$ & $\begin{array}{l}\text { ened } \\
\text { rval } \\
\text { above } \\
\text { low (-) } \\
\text { level) }\end{array}$ & Aquifer ${ }^{1}$ & $\begin{array}{l}\text { Date } \\
\text { sampled } 2\end{array}$ & $\begin{array}{l}\text { Spe- } \\
\text { cif1c } \\
\text { conduct- } \\
\text { ance } \\
(\mu \mathrm{s} / \mathrm{cm})\end{array}$ & $\begin{array}{c}\text { pH } \\
\text { (units) }\end{array}$ & $\begin{array}{l}\text { Field } \\
\text { temp } \\
\text { (deg C) }\end{array}$ & $\begin{array}{l}\text { Color } \\
\text { (unit) }\end{array}$ & $\begin{array}{l}\text { Tur- } \\
\text { b1dity } \\
\text { (NTU) }\end{array}$ & $\begin{array}{l}\text { Hard- } \\
\text { ness } \\
(\mathrm{mg} / \mathrm{L} \\
\text { as } \\
\left.\mathrm{CaCO}_{3}\right)\end{array}$ & $\begin{array}{l}\text { Calcium, } \\
\text { total } \\
\text { (mg/L } \\
\text { as Ca) }\end{array}$ & $\begin{array}{l}\text { Magne- } \\
\text { sium, } \\
\text { total } \\
\text { mg/L } \\
\text { as } \mathrm{Mg} \text { ) }\end{array}$ \\
\hline 01187 & 403958 & 734458 & & to -120 & Jameco & $7 / 14 / 83$ & 190 & 6.3 & 14 & 14 & 5.4 & 52 & 12 & 5.2 \\
\hline Q1189 & 403958 & 734458 & & to -35 & Upglac & $\begin{array}{l}2 / 18 / 81 \\
6 / 7 / 83\end{array}$ & $\begin{array}{l}1,650 \\
1,570\end{array}$ & $\begin{array}{l}6.2 \\
6.3\end{array}$ & $\begin{array}{l}14 \\
15\end{array}$ & $\begin{array}{l}27 \\
30\end{array}$ & 27.0 & $\begin{array}{l}470 \\
250\end{array}$ & $\overline{91}$ & -- \\
\hline 01237 & 403959 & 734744 & & to -200 & Jameco & $10 / 6 / 83$ & 1,270 & 7.6 & 14 & 8 & 1.2 & 410 & 150 & 46 \\
\hline 01241 & 404436 & 735218 & -209 & to -249 & Lloyd & $\begin{array}{l}3 / 3 / 81 \\
6 / 15 / 83\end{array}$ & $\begin{array}{l}230 \\
280\end{array}$ & $\begin{array}{l}6.5 \\
6.5\end{array}$ & $\overline{16}$ & $\begin{array}{l}170 \\
450\end{array}$ & $\begin{array}{r}>25 \\
45\end{array}$ & $\begin{array}{l}60 \\
54\end{array}$ & $\begin{array}{l}15 \\
15\end{array}$ & $\begin{array}{l}5.4 \\
5.9\end{array}$ \\
\hline $\begin{array}{l}01373 \\
01472\end{array}$ & $\begin{array}{l}404656 \\
404415\end{array}$ & $\begin{array}{l}735037 \\
734656\end{array}$ & $\begin{array}{l}-144 \\
-122\end{array}$ & $\begin{array}{l}\text { to }-156 \\
\text { to }-152\end{array}$ & $\begin{array}{l}\text { Lloyd } \\
\text { Mag }\end{array}$ & $\begin{array}{l}9 / 22 / 83 \\
9 / 22 / 83\end{array}$ & $\begin{array}{r}3,300 \\
360\end{array}$ & $\begin{array}{l}7.8 \\
6.8\end{array}$ & $\begin{array}{l}16 \\
16.5\end{array}$ & $\begin{array}{r}25 \\
3\end{array}$ & $\begin{array}{l}.7 \\
.6\end{array}$ & $\begin{array}{l}380 \\
120\end{array}$ & $\begin{array}{l}90 \\
28\end{array}$ & $\begin{array}{l}28 \\
56\end{array}$ \\
\hline 01506 & 403945 & 734825 & -81 & to -93 & Upglac & $8 / 9 / 83$ & 5,000 & 6.9 & 15 & - & 4.5 & 1,100 & 150 & 150 \\
\hline Q1605 & 404357 & 735204 & -6 & to -17 & Upglac & $\begin{array}{l}2 / 20 / 81 \\
9 / 1 / 83\end{array}$ & $\begin{array}{l}850 \\
950\end{array}$ & $\begin{array}{l}7.0 \\
7.1\end{array}$ & $\begin{array}{c}15.5 \\
--\end{array}$ & $\begin{array}{l}4 \\
9\end{array}$ & $\begin{array}{r}1.0 \\
.6\end{array}$ & $\begin{array}{l}410 \\
430\end{array}$ & $\overline{120}$ & $\overline{55}$ \\
\hline 01663 & 404205 & 735218 & -31 & to -41 & Upglac & $\begin{array}{l}2 / 19 / 81 \\
8 / 8 / 83\end{array}$ & $\begin{array}{l}730 \\
881\end{array}$ & $\begin{array}{l}7.3 \\
7.3\end{array}$ & $14^{9.0}$ & $\begin{array}{l}9 \\
2\end{array}$ & $\begin{array}{r}3.9 \\
.7\end{array}$ & $\begin{array}{l}370 \\
440\end{array}$ & 110 & $-\overline{45}$ \\
\hline $\begin{array}{l}Q 1914 \\
Q 1930\end{array}$ & $\begin{array}{l}404418 \\
403633\end{array}$ & $\begin{array}{l}734342 \\
734525\end{array}$ & $\begin{array}{l}-112 \\
-91\end{array}$ & $\begin{array}{l}\text { to }-138 \\
\text { to }-111\end{array}$ & $\begin{array}{l}\text { Mag } \\
\text { Upglac }\end{array}$ & $\begin{array}{l}8 / 25 / 83 \\
3 / 17 / 81 \\
6 / 23 / 83\end{array}$ & $\begin{array}{r}550 \\
>8,000 \\
>9,000\end{array}$ & $\begin{array}{l}5.9 \\
6.8 \\
6.5\end{array}$ & $\begin{array}{l}13 \\
13.5 \\
15\end{array}$ & $\begin{array}{r}7 \\
90 \\
120\end{array}$ & $\begin{array}{c}1.2 \\
>25 \\
12\end{array}$ & $\begin{array}{r}610 \\
2,800 \\
3,100\end{array}$ & $\begin{array}{r}31 \\
240 \\
320\end{array}$ & $\begin{array}{r}17 \\
520 \\
440\end{array}$ \\
\hline $\begin{array}{l}Q 2289 \\
Q 2324\end{array}$ & $\begin{array}{l}404016 \\
403957\end{array}$ & $\begin{array}{l}735006 \\
734950\end{array}$ & -66 & $\begin{array}{l}\text { to }-117 \\
\text { to }-69\end{array}$ & $\begin{array}{l}\text { Upglac } \\
\text { Upglac }\end{array}$ & $\begin{array}{l}7 / 27 / 83 \\
2 / 13 / 81\end{array}$ & $\begin{array}{l}2,340 \\
1,030\end{array}$ & 6.8 & 15 & $\begin{array}{l}8 \\
5\end{array}$ & $\begin{array}{r}1.0 \\
2.8\end{array}$ & $\begin{array}{l}750 \\
450\end{array}$ & $\begin{array}{l}140 \\
--\end{array}$ & $\begin{array}{l}90 \\
--\end{array}$ \\
\hline $\begin{array}{l}02384 \\
02407\end{array}$ & $\begin{array}{l}404022 \\
404320\end{array}$ & $\begin{array}{l}734957 \\
734748\end{array}$ & $\begin{array}{l}-92 \\
-19\end{array}$ & $\begin{array}{l}\text { to }-123 \\
\text { to }-45\end{array}$ & $\begin{array}{l}\text { Upglac } \\
\text { Upglac }\end{array}$ & $\begin{array}{l}7 / 27 / 83 \\
9 / 7 / 83\end{array}$ & $\begin{array}{r}2,290 \\
500\end{array}$ & $\begin{array}{l}1.5 \\
7.4 \\
6.3\end{array}$ & $\begin{array}{l}14 \\
14 \\
13.5\end{array}$ & $\begin{array}{l}6 . \\
5 \\
7\end{array}$ & $\begin{array}{r}3.2 \\
.3 \\
1.0\end{array}$ & $\begin{array}{l}410 \\
750 \\
190\end{array}$ & $\begin{array}{r}140 \\
40\end{array}$ & $\begin{array}{l}54 \\
90 \\
28\end{array}$ \\
\hline
\end{tabular}

Potas- Alka- Sulfate, Chloride, Fluo- Total Nitrogen, Nitrogen

\begin{tabular}{|c|c|c|c|c|c|c|c|c|c|c|c|c|}
\hline $\begin{array}{l}\text { Well } \\
\text { no. }\end{array}$ & $\begin{array}{l}\text { Date } \\
\text { sampled }\end{array}$ & $\begin{array}{l}\text { Sodium, } \\
\text { total } \\
\text { (mg/L } \\
\text { as } \mathrm{Na})\end{array}$ & $\begin{array}{l}\text { Potas- } \\
\text { sium, } \\
\text { total } \\
\text { mg } / \mathrm{L} \\
\text { as } \mathrm{K} \text { ) }\end{array}$ & $\begin{array}{l}\text { Alka- } \\
\text { linity } \\
\text { (mg/L } \\
\text { as } \\
\mathrm{CaCO}_{3} \text { ) }\end{array}$ & $\begin{array}{l}\text { Sulfate, } \\
\text { dis- } \\
\text { solved } \\
\text { (mg/L } \\
\text { as SO4) }\end{array}$ & $\begin{array}{l}\text { Chloride, } \\
\text { dis- } \\
\text { solved } \\
\text { (mg/L } \\
\text { as (C1) }\end{array}$ & $\begin{array}{l}\text { Fluo- } \\
\text { rlde, } \\
\text { total } \\
\text { (mg/L } \\
\text { as F) }\end{array}$ & $\begin{array}{l}\text { Total } \\
\text { dis- } \\
\text { solved } \\
\text { solids } \\
\text { (mg/L) }\end{array}$ & $\begin{array}{l}\text { Nitrogen, } \\
\text { as nftrate, } \\
\text { total } \\
\text { (mg/L } \\
\text { as } N \text { ) }\end{array}$ & $\begin{array}{l}\text { Nitrogen } \\
\text { as ammonia, } \\
\text { total } \\
\text { (mg/L } \\
\text { as } \mathrm{N} \text { ) }\end{array}$ & $\begin{array}{l}\text { Arsenic, } \\
\text { total } \\
\text { ( } \mu g / L \\
\text { as As) }\end{array}$ & $\begin{array}{l}\text { Cadmium, } \\
\text { total } \\
(\mu g / L \\
\text { as Cd) }\end{array}$ \\
\hline Q1187 & $7 / 14 / 83$ & 9.9 & 2 & 36 & 29 & 10 & 0.2 & 111 & .79 & 0.01 & $<50$ & $<10$ \\
\hline \multirow[t]{2}{*}{ Q1189 } & $2 / 18 / 81$ & -- & -- & 86 & 52 & 470 & -- & 1,020 & 1.0 & .96 & $<50$ & $<10$ \\
\hline & $6 / 7 / 83$ & 150 & 11 & 120 & 90 & 340 & 1 & 999 & - & .30 & $<50$ & $<10$ \\
\hline Q1237 & $10 / 6 / 83$ & 68 & 7 & 90 & 25 & 330 & .4 & 779 & -- & $<.03$ & $<50$ & $<10$ \\
\hline \multirow[t]{2}{*}{ Q1241 } & $3 / 3 / 81$ & 22 & 2 & 74 & 18 & 12 & -- & 120 & 1.2 & .45 & $<50$ & $<10$ \\
\hline & $6 / 15 / 83$ & 21 & 4 & 72 & 34 & 14 & .3 & 148 & 3.7 & .01 & $<50$ & $<10$ \\
\hline Q1373 & $9 / 22 / 83$ & 520 & 15 & 4 & 70 & 1,200 & .4 & 2,350 & .14 & $<.03$ & $<50$ & $<10$ \\
\hline 01472 & $9 / 22 / 83$ & 15 & 2 & 68 & 41 & 37 & .3 & 227 & $>10$ & $<.03$ & $<50$ & $<10$ \\
\hline Q1506 & $8 / 9 / 83$ & 870 & 40 & 550 & 290 & 1,700 & .2 & 3,780 & .36 & $<.03$ & $<50$ & $<10$ \\
\hline \multirow[t]{2}{*}{ Q1605 } & $2 / 20 / 81$ & -- & -- & 210 & 95 & 62 & - & 560 & 12 & .21 & $<50$ & $<10$ \\
\hline & $9 / 1 / 83$ & 16 & 6 & 240 & 49 & 120 & .2 & -- & .80 & -- & $<50$ & $<10$ \\
\hline \multirow[t]{2}{*}{21663} & $2 / 19 / 81$ & - & -- & 150 & 97 & 45 & - & 570 & 10 & .09 & $<50$ & $<10$ \\
\hline & $8 / 8 / 83$ & 20 & 2 & 280 & 98 & 51 & .1 & 588 & $>10$ & $<.03$ & $<10$ & $<10$ \\
\hline Q1914 & $8 / 25 / 83$ & 44 & 1 & 170 & 20 & 360 & .2 & - & 9.5 & $<.03$ & $<50$ & $<10$ \\
\hline \multirow[t]{2}{*}{01930} & $3 / 17 / 81$ & 5,600 & 120 & 110 & 1,000 & 500 & .2 & 14,000 & .30 & .15 & - & - \\
\hline & $6 / 23 / 83$ & 4,500 & 120 & 120 & 1,070 & 9,000 & .2 & 21,700 & 1.2 & .05 & $<50$ & $<10$ \\
\hline$Q 2289$ & $7 / 27 / 83$ & 220 & 4 & 90 & 120 & 650 & - & 1,570 & 6.9 & .03 & $<50$ & $<10$ \\
\hline \multirow[t]{2}{*}{02324} & $2 / 13 / 81$ & - & -- & 210 & 100 & 140 & -- & 750 & 9.6 & .06 & $<50$ & $<10$ \\
\hline & $6 / 6 / 83$ & 38 & -- & 150 & 100 & 140 & 1 & 672 & 22 & .09 & - & $<10$ \\
\hline 02384 & $7 / 27 / 83$ & 200 & 4 & 92 & 120 & 640 & -- & 1,560 & 7.8 & .03 & $<50$ & $<10$ \\
\hline Q2407 & $9 / 7 / 83$ & 28 & 3 & 80 & 40 & 57 & .2 & 350 & 4.8 & $<.03$ & $<50$ & $<10$ \\
\hline
\end{tabular}


Table 10.--Selected chemical analyses of ground water sampled from observation wells in Kings, Queens, and eastern Nassau Counties (continued)

\begin{tabular}{|c|c|c|c|c|c|c|c|c|c|c|c|}
\hline $\begin{array}{l}\text { Well } \\
\text { no. }\end{array}$ & $\begin{array}{l}\text { Date } \\
\text { sampled }\end{array}$ & $\begin{array}{l}\text { Chromium, } \\
\text { total } \\
\mu g / L \\
\text { as } C r)\end{array}$ & $\begin{array}{l}\text { Copper, } \\
\text { total } \\
\text { ( } \mu g / \mathrm{L} \\
\text { as Cu) }\end{array}$ & $\begin{array}{l}\text { Iron, } \\
\text { total } \\
\text { ( } \mu \text { g/L } \\
\text { as Fe) }\end{array}$ & $\begin{array}{l}\text { Lead, } \\
\text { total } \\
(\mu g / L \\
\text { as } \mathrm{Pb})\end{array}$ & $\begin{array}{l}\text { Manganese } \\
\text { total } \\
(\mu \mathrm{g} / \mathrm{L} \\
\text { as } \mathrm{Mn})\end{array}$ & $\begin{array}{l}\text { Mercury, } \\
\text { total } \\
(\mu g / L \\
\text { as } \mathrm{Hg})\end{array}$ & $\begin{array}{l}\text { Selenium, } \\
\text { total } \\
\mu g / L \\
\text { as Sel }\end{array}$ & $\begin{array}{l}\text { Silver, } \\
\text { total } \\
\text { ( } \mu g / L \\
\text { as } \mathrm{Ag})\end{array}$ & $\begin{array}{l}\text { Zinc, } \\
\text { total } \\
(\mu \mathrm{g} / \mathrm{L} \\
\text { as } \mathrm{Zn})\end{array}$ & $\begin{array}{l}\text { Linear } \\
\text { alkyl } \\
\text { sul- } \\
\text { fonate }\end{array}$ \\
\hline 01187 & $7 / 14 / 83$ & $<30$ & 10 & 9,500 & $<30$ & 1,400 & $<1$ & $<10$ & $<50$ & 20 & neg \\
\hline \multirow[t]{2}{*}{ Q1189 } & $2 / 18 / 81$ & $<40$ & 10 & 22,000 & $<10$ & 1,800 & $<1$ & $<10$ & $<30$ & 90 & -- \\
\hline & $6 / 7 / 83$ & $<30$ & 20 & 22,000 & 50 & 1,300 & $<1$ & $<10$ & $<50$ & -- & neg \\
\hline Q1237 & $10 / 6 / 83$ & $<30$ & 20 & 1,200 & $<30$ & 650 & 1 & $<10$ & $<50$ & 60 & neg \\
\hline \multirow[t]{2}{*}{ Q1241 } & $3 / 3 / 81$ & $<40$ & 180 & 16,000 & $<10$ & 70 & $<1$ & $<10$ & $<30$ & 10 & neg \\
\hline & $6 / 15 / 83$ & $<30$ & 7200 & 14,000 & $<30$ & 140 & $<1$ & $<10$ & $<50$ & 730 & neg \\
\hline Q1373 & $9 / 22 / 83$ & $<30$ & 60 & 10,000 & $<30$ & 1,200 & $<1$ & $<10$ & $<50$ & 600 & neg \\
\hline Q1472 & $9 / 22 / 83$ & $<30$ & 20 & 80 & $<30$ & 20 & $<1$ & $<10$ & $<50$ & 90 & neg \\
\hline Q1506 & $8 / 9 / 83$ & $<30$ & 80 & 650 & 100 & 3,700 & $<1$ & $<10$ & $<50$ & 120 & neg \\
\hline \multirow[t]{2}{*}{ Q1605 } & $2 / 20 / 81$ & $<40$ & 90 & 180 & $<10$ & 20 & $<1$ & $<10$ & $<30$ & 200 & neg \\
\hline & $9 / 1 / 83$ & $<30$ & 10 & 800 & $<30$ & 10 & $<1$ & $<10$ & $<50$ & 150 & neg \\
\hline \multirow[t]{2}{*}{ Q1663 } & $2 / 19 / 81$ & $<40$ & 80 & 480 & $<10$ & 40 & $<1$ & $<10$ & $<30$ & 150 & neg \\
\hline & $8 / 8 / 83$ & $<30$ & 50 & 60 & $<30$ & 10 & $<1$ & $<10$ & $<50$ & 100 & neg \\
\hline 01914 & $8 / 25 / 83$ & $<30$ & 40 & 40 & $<30$ & 470 & $<1$ & $<10$ & $<50$ & 100 & neg \\
\hline \multirow[t]{2}{*}{ Q1930 } & $3 / 17 / 81$ & $<50$ & 60 & 30,000 & $<30$ & 2,400 & $<1$ & -- & $<30$ & 30 & neg \\
\hline & $6 / 23 / 83$ & $<30$ & 130 & 34,000 & $<30$ & 1,900 & $<1$ & $<10$ & $<50$ & 100 & neg \\
\hline Q2289 & $7 / 27 / 83$ & $<30$ & 10 & 30 & $<30$ & 30 & $<1$ & $<10$ & $<50$ & 50 & neg \\
\hline \multirow[t]{2}{*}{02324} & $2 / 13 / 81$ & $<40$ & 10 & 850 & $<10$ & 30 & $<1$ & $<10$ & $<30$ & 950 & neg \\
\hline & $6 / 6 / 83$ & $<30$ & 100 & 400 & $<30$ & 10 & $<1$ & -- & -- & -- & neg \\
\hline Q2384 & $7 / 27 / 83$ & $<30$ & 200 & 150 & $<30$ & 180 & $<1$ & $<10$ & $<50$ & 60 & neg \\
\hline 02407 & $9 / 7 / 83$ & $<30$ & 100 & 230 & $<30$ & 50 & $<1$ & $<10$ & $<50$ & 120 & neg \\
\hline
\end{tabular}


Table 10.--Selected chemical analyses of ground water sampled from observation wells in Kings, Queens, and eastern Nassau Counties (continued)

\begin{tabular}{|c|c|c|c|c|c|c|c|c|c|c|c|c|c|}
\hline $\begin{array}{c}\text { Well } \\
\text { no }\end{array}$ & Lat & Long & $\begin{array}{l}\text { Screened } \\
\text { interval } \\
\text { (ft above } \\
\text { or below (-) } \\
\text { sea level) }\end{array}$ & Aquifer ${ }^{1}$ & $\begin{array}{l}\text { Date } \\
\text { sampled }\end{array}$ & $\begin{array}{l}\text { Spe- } \\
\text { cific } \\
\text { conduct- } \\
\text { ance } \\
(\mu \mathrm{s} / \mathrm{cm})\end{array}$ & $\begin{array}{c}\mathrm{pH} \\
\text { (units) }\end{array}$ & $\begin{array}{l}\text { Field } \\
\text { temp } \\
\text { (deg c) }\end{array}$ & $\begin{array}{l}\text { Color } \\
\text { (unit) }\end{array}$ & $\begin{array}{l}\text { Tur- } \\
\text { bidity } \\
\text { (NTU) }\end{array}$ & $\begin{array}{l}\text { Hard- } \\
\text { ness } \\
(\mathrm{mg} / \mathrm{L} \\
\mathrm{as} \\
\left.\mathrm{CaCO}_{3}\right)\end{array}$ & $\begin{array}{l}\text { Calcium, } \\
\text { total } \\
\text { (mg/L } \\
\text { as Ca) }\end{array}$ & $\begin{array}{l}\text { Magne- } \\
\text { sium, } \\
\text { total } \\
\text { mg/L } \\
\text { as } \mathrm{Mg} \text { ) }\end{array}$ \\
\hline
\end{tabular}

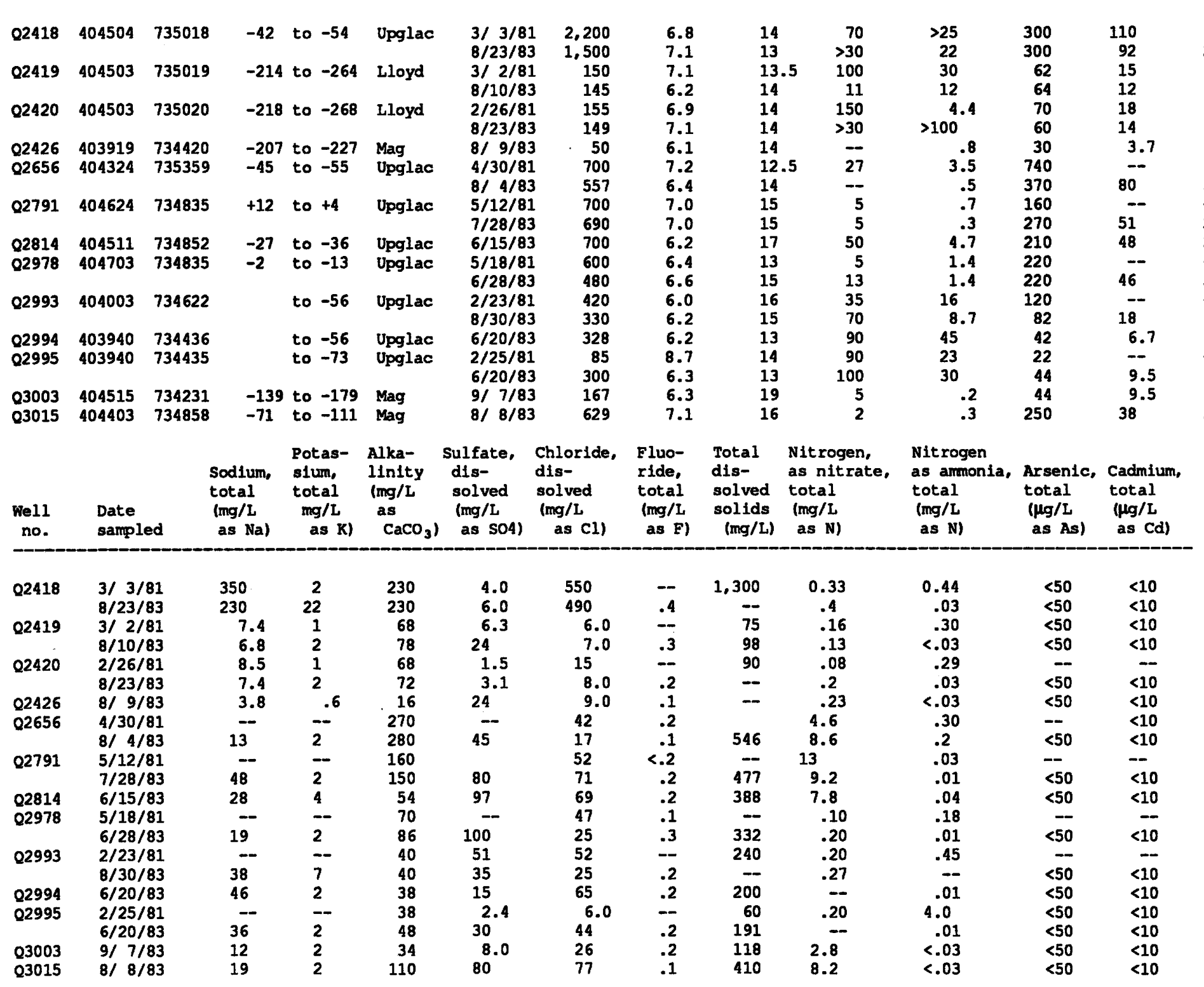


Table 10.--Selected chemical analyses of ground water sampled from observation wells in Kings, Queens, and eastern Nassau Counties (continued)

\begin{tabular}{|c|c|c|c|c|c|c|c|c|c|c|c|}
\hline $\begin{array}{l}\text { Well } \\
\text { no. }\end{array}$ & $\begin{array}{l}\text { Date } \\
\text { sampled }\end{array}$ & $\begin{array}{l}\text { Chromium, } \\
\text { total } \\
\mu g / L \\
\text { as (Cr) }\end{array}$ & $\begin{array}{l}\text { Copper, } \\
\text { total } \\
(\mu g / L \\
\text { as Cu) }\end{array}$ & $\begin{array}{l}\text { Iron, } \\
\text { total } \\
(\mu g / L \\
\text { as Fe) }\end{array}$ & $\begin{array}{l}\text { Lead, } \\
\text { total } \\
(\mu g / \mathrm{L} \\
\text { as } \mathrm{Pb})\end{array}$ & $\begin{array}{l}\text { Manganese } \\
\text { total } \\
\text { ( } \mu g / \mathrm{L} \\
\text { as Mn) }\end{array}$ & $\begin{array}{l}\text { Mercury, } \\
\text { total } \\
\text { ( } \mu g / L \\
\text { as } \mathrm{Hg})\end{array}$ & $\begin{array}{l}\text { Selenium, } \\
\text { total } \\
\mu g / L \\
\text { as } \mathrm{Se})\end{array}$ & $\begin{array}{l}\text { silver, } \\
\text { total } \\
\text { ( } \mu g / L \\
\text { as } \mathrm{Ag})\end{array}$ & $\begin{array}{l}\text { Zinc, } \\
\text { total } \\
(\mu \mathrm{gg} / \mathrm{L} \\
\text { as } \mathrm{Zn})\end{array}$ & $\begin{array}{l}\text { Linear } \\
\text { alkyl } \\
\text { sul- } \\
\text { fonate }\end{array}$ \\
\hline \multirow[t]{2}{*}{02418} & $3 / 3 / 81$ & $<40$ & 0 & 32,000 & $<10$ & 1,400 & $<1$ & $<10$ & $<30$ & 30 & neg \\
\hline & $8 / 23 / 83$ & $<30$ & 50 & 22,000 & $<30$ & 880 & $<1$ & $<10$ & $<50$ & 200 & neg \\
\hline \multirow[t]{2}{*}{02419} & $3 / 2 / 81$ & $<40$ & 70 & 3,600 & $<10$ & 120 & $<1$ & $<10$ & $<30$ & 40 & neg \\
\hline & $8 / 10 / 83$ & $<30$ & 30 & 4,300 & $<30$ & 130 & $<1$ & $<10$ & $<50$ & 20 & neg \\
\hline \multirow[t]{2}{*}{02420} & $2 / 26 / 81$ & -- & -- & -- & $<10$ & - & - & -- & -- & -- & -- \\
\hline & $8 / 23 / 83$ & $<30$ & 50 & 3,500 & $<30$ & 230 & $<1$ & $<10$ & $<50$ & 100 & neg \\
\hline \multirow{3}{*}{02656} & $8 / 9 / 83$ & $<30$ & 10 & 450 & $<30$ & 80 & $<1$ & $<10$ & $<50$ & 20 & neg \\
\hline & $4 / 30 / 81$ & $<50$ & 140 & 4,800 & $<30$ & & -- & -- & -- & 44,000 & neg \\
\hline & $8 / 4 / 83$ & $<30$ & 30 & 220 & $<30$ & 80 & $<1$ & $<10$ & $<50$ & 120 & neg \\
\hline \multirow[t]{2}{*}{ Q2791 } & $5 / 12 / 81$ & -- & -- & 90 & $<30$ & -- & - & -- & -- & -- & neg \\
\hline & $7 / 28 / 83$ & $<30$ & 50 & 280 & $<30$ & 10 & $<1$ & $<10$ & $<50$ & 170 & neg \\
\hline Q2814 & $6 / 15 / 83$ & $<30$ & 130 & 530 & $<30$ & 50 & $<1$ & $<10$ & $<50$ & 70 & neg \\
\hline \multirow{2}{*}{02978} & $5 / 18 / 81$ & -- & -- & -- & $<30$ & -- & -- & -- & -- & -- & neg \\
\hline & $6 / 28 / 83$ & $<30$ & 60 & 450 & -- & 230 & $<1$ & $<10$ & $<50$ & 130 & neg \\
\hline \multirow[t]{2}{*}{02993} & $2 / 23 / 81$ & -- & -- & - & $<10$ & -- & $<1$ & -- & -- & - & neg \\
\hline & $8 / 30 / 83$ & $<30$ & 70 & 3,800 & $<30$ & 210 & $<1$ & $<10$ & $<50$ & 120 & neg \\
\hline Q2994 & $6 / 20 / 83$ & $<30$ & 160 & 10,000 & $<50$ & 420 & $<1$ & $<10$ & $<50$ & 130 & neg \\
\hline \multirow[t]{2}{*}{02995} & $2 / 25 / 81$ & $<40$ & 50 & 4,200 & $<10$ & 10 & $<1$ & $<10$ & $<30$ & 40 & neg \\
\hline & $6 / 20 / 83$ & $<30$ & 230 & 12,000 & $<30$ & 400 & $<1$ & $<10$ & $<50$ & 90 & neg \\
\hline Q3003 & $9 / 7 / 83$ & $<30$ & 50 & 40 & $<30$ & 30 & $<1$ & $<10$ & $<50$ & 100 & neg \\
\hline Q3015 & $8 / 8 / 83$ & $<30$ & 40 & 160 & $<30$ & 10 & $<1$ & $<10$ & $<50$ & 40 & neg \\
\hline
\end{tabular}


Table 10.--Selected chemical analyses of ground water sampled from observation wells in Kings, Queens, and eastern Nassau Counties (continued)

\begin{tabular}{|c|c|c|c|c|c|c|c|c|c|c|c|c|c|c|}
\hline $\begin{array}{l}\text { Well } \\
\text { no. }\end{array}$ & Lat & Long & $\begin{array}{l}\text { Scree } \\
\text { inter } \\
\text { (ft a } \\
\text { or be } \\
\text { sea I }\end{array}$ & $\begin{array}{l}\text { ened } \\
\text { rval } \\
\text { above } \\
\text { elow (-) } \\
\text { level) }\end{array}$ & Aquifer ${ }^{1}$ & $\begin{array}{l}\text { Date } \\
\text { sampled }\end{array}$ & $\begin{array}{l}\text { Spe- } \\
\text { cific } \\
\text { conduct- } \\
\text { ance } \\
(\mu s / c m)\end{array}$ & $\begin{array}{c}\mathrm{pH} \\
\text { (units) }\end{array}$ & $\begin{array}{l}\text { Field } \\
\text { temp } \\
\text { (deg c) }\end{array}$ & $\begin{array}{l}\text { Color } \\
\text { (unit) }\end{array}$ & $\begin{array}{l}\text { Tur- } \\
\text { bidity } \\
\text { (NTU) }\end{array}$ & $\begin{array}{l}\text { Hard- } \\
\text { ness } \\
(\mathrm{mg} / \mathrm{L} \\
\mathrm{as} \\
\left.\mathrm{CaCO}_{3}\right)\end{array}$ & $\begin{array}{l}\text { Calclum, } \\
\text { total } \\
\text { (mg/L } \\
\text { as Ca) }\end{array}$ & $\begin{array}{l}\text { Magne- } \\
\text { slum, } \\
\text { total } \\
\text { mg/L } \\
\text { as } \mathrm{Mg} \text { ) }\end{array}$ \\
\hline Q3036 & 404354 & 735200 & -229 & to -249 & Lloyd & $\begin{array}{l}3 / 2 / 81 \\
6 / 21 / 83\end{array}$ & $\begin{array}{l}195 \\
270\end{array}$ & $\begin{array}{l}6.7 \\
6.9\end{array}$ & $\begin{array}{l}12.5 \\
14\end{array}$ & $\begin{array}{r}150 \\
55\end{array}$ & $\begin{array}{l}45 \\
60\end{array}$ & $\begin{array}{l}36 \\
34\end{array}$ & $\begin{array}{l}9.0 \\
9.5\end{array}$ & $\begin{array}{l}3.2 \\
--\end{array}$ \\
\hline Q3109 & 403932 & 734829 & -268 & to -288 & Mag & $8 / 18 / 83$ & 10,500 & 6.7 & 15 & 50 & 61 & 14,000 & 190 & 230 \\
\hline 03110 & 403845 & 734757 & -296 & to -316 & Jameco & $7 / 18 / 83$ & 6,520 & 6.7 & 15 & 85 & 29 & 1,600 & 400 & 150 \\
\hline 03112 & 403939 & 734728 & -279 & to -289 & Jameco & $8 / 15 / 83$ & 478 & 7.8 & 14 & 7 & 1.5 & 160 & 48 & 13 \\
\hline $\begin{array}{l}03114 \\
03115\end{array}$ & $\begin{array}{l}403932 \\
403845\end{array}$ & $\begin{array}{l}734829 \\
734757\end{array}$ & -7 & $\begin{array}{l}\text { to }-9 \\
\text { to }-16\end{array}$ & $\begin{array}{l}\text { Upglac } \\
\text { Upglac }\end{array}$ & $\begin{array}{l}8 / 18 / 83 \\
7 / 18 / 83\end{array}$ & $\begin{array}{r}950 \\
5,620\end{array}$ & $\begin{array}{l}6.7 \\
7.0\end{array}$ & $\begin{array}{l}13 \\
18\end{array}$ & $\begin{array}{l}30 \\
55\end{array}$ & $\begin{array}{l}30 \\
30\end{array}$ & $\begin{array}{l}440 \\
800\end{array}$ & $\begin{array}{r}94 \\
110\end{array}$ & $\begin{array}{l}13 \\
78\end{array}$ \\
\hline 03117 & 403939 & 734728 & & to -12 & Upglac & $\begin{array}{l}2 / 9 / 81 \\
8 / 15 / 83\end{array}$ & $\begin{array}{l}740 \\
681\end{array}$ & $\begin{array}{l}6.9 \\
6.2\end{array}$ & $\begin{array}{l}14.5 \\
15\end{array}$ & $\begin{array}{l}23 \\
12\end{array}$ & $\begin{array}{c}14 \\
3.3\end{array}$ & $\begin{array}{l}250 \\
290\end{array}$ & 90 & $12^{--}$ \\
\hline 03119 & 404654 & 734659 & +4 & to +1 & Upglac & $\begin{array}{l}2 / 9 / 81 \\
8 / 8 / 83\end{array}$ & $\begin{array}{r}870 \\
1,040\end{array}$ & $\begin{array}{l}5.9 \\
5.7\end{array}$ & $\begin{array}{l}16.5 \\
15.5\end{array}$ & $\begin{array}{l}18 \\
28\end{array}$ & $>25$ & $\begin{array}{l}290 \\
310\end{array}$ & $65^{--}$ & 27 \\
\hline Q3121 & 404631 & 735439 & +6 & to +3 & Upglac & $\begin{array}{l}2 / 27 / 81 \\
6 / 13 / 83\end{array}$ & $\begin{array}{l}1,200 \\
1,170\end{array}$ & $\begin{array}{l}7.2 \\
--\end{array}$ & $\begin{array}{l}15 \\
16\end{array}$ & $\begin{array}{r}15 \\
100\end{array}$ & $\begin{array}{l}>25 \\
10.3\end{array}$ & $\begin{array}{l}400 \\
270\end{array}$ & $120^{--}$ & $\begin{array}{r}110 \\
43\end{array}$ \\
\hline 03123 & 404421 & 735132 & +1 & to -2 & Upglac & $\begin{array}{l}2 / 9 / 81 \\
6 / 20 / 83\end{array}$ & $\begin{array}{r}1,100 \\
865\end{array}$ & $\begin{array}{l}7.1 \\
7.4\end{array}$ & $\begin{array}{l}15 \\
15\end{array}$ & $\begin{array}{l}13 \\
40\end{array}$ & $\begin{array}{l}25 \\
16\end{array}$ & $\begin{array}{l}440 \\
410\end{array}$ & $100^{--}$ & 34 \\
\hline $\begin{array}{l}03134 \\
03150\end{array}$ & $\begin{array}{l}404521 \\
403949\end{array}$ & $\begin{array}{l}735051 \\
734957\end{array}$ & -223 & $\begin{array}{l}\text { to }-233 \\
\text { to }-119\end{array}$ & $\begin{array}{l}\text { Upglac } \\
\text { Jameco }\end{array}$ & $\begin{array}{l}9 / 20 / 83 \\
6 / 21 / 83\end{array}$ & $\begin{array}{r}1,850 \\
>9,000\end{array}$ & $\begin{array}{l}6.2 \\
7.0\end{array}$ & $\begin{array}{l}14.5 \\
15\end{array}$ & -3 & $80^{.5}$ & $\begin{array}{r}320 \\
5,400\end{array}$ & $\begin{array}{r}50 \\
400\end{array}$ & $\begin{array}{r}48 \\
810\end{array}$ \\
\hline $\begin{array}{l}\text { N1429 } \\
\text { N1627 }\end{array}$ & $\begin{array}{l}403920 \\
403908\end{array}$ & $\begin{array}{l}734107 \\
734320\end{array}$ & $\begin{array}{l}-5 \\
-9\end{array}$ & $\begin{array}{l}\text { to }-8 \\
\text { to }-12\end{array}$ & $\begin{array}{l}\text { Upglac } \\
\text { Upglac }\end{array}$ & $\begin{array}{l}9 / 27 / 83 \\
4 / 13 / 81\end{array}$ & $\begin{array}{l}394 \\
440\end{array}$ & $\begin{array}{l}6.1 \\
6.0\end{array}$ & $\begin{array}{l}20 \\
16\end{array}$ & $\begin{array}{r}10 \\
7\end{array}$ & $\begin{array}{l}1.2 \\
1.1\end{array}$ & $\begin{array}{l}250 \\
120\end{array}$ & $\begin{array}{l}40 \\
26\end{array}$ & $\begin{array}{c}6.2 \\
14\end{array}$ \\
\hline & & & & & & $7 / 21 / 83$ & 364 & 6. & 16 & 1 & 3.8 & 170 & 55 & 8.5 \\
\hline N3864 & 403827 & 734250 & -457 & to -468 & Mag & $10 / 3 / 83$ & 80 & 5.6 & 15 & 12 & 5.1 & 10 & 2.0 & 1.0 \\
\hline
\end{tabular}

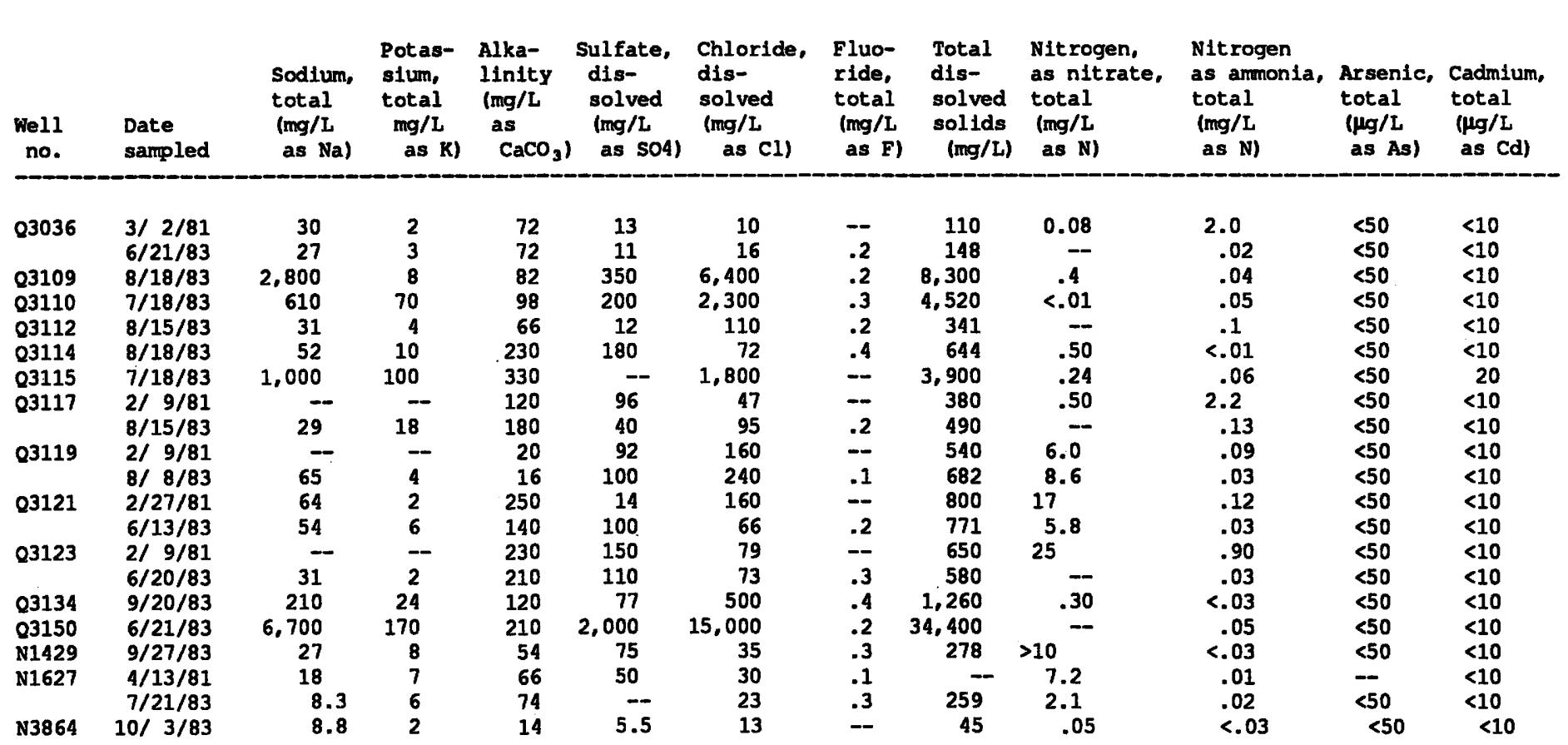


I'able 10.--Selected chemical analyses of ground water sampled from observation wells in Kings, Queens, and eastern Nassau Counties (continued)

\begin{tabular}{|c|c|c|c|c|c|c|c|c|c|c|c|}
\hline $\begin{array}{l}\text { well } \\
\text { no. }\end{array}$ & $\begin{array}{l}\text { Date } \\
\text { sampled }\end{array}$ & $\begin{array}{l}\text { Chromium, } \\
\text { total } \\
\mu g / L \\
\text { as }(r)\end{array}$ & $\begin{array}{l}\text { Copper, } \\
\text { total } \\
(\mu g / L \\
\text { as Cu) }\end{array}$ & $\begin{array}{l}\text { Iron, } \\
\text { total } \\
\text { ( } \mu \text { g/L } \\
\text { as } \mathrm{Fe})\end{array}$ & $\begin{array}{l}\text { Lead, } \\
\text { total } \\
(\mu \mathrm{g} / \mathrm{L} \\
\text { as } \mathrm{Pb})\end{array}$ & $\begin{array}{l}\text { Manganese } \\
\text { total } \\
\text { ( } \mu g / L \\
\text { as } \mathrm{Mn})\end{array}$ & $\begin{array}{l}\text { Mercury, } \\
\text { total } \\
(\mu \mathrm{g} / \mathrm{L} \\
\text { as } \mathrm{Hg})\end{array}$ & $\begin{array}{l}\text { Selenium, } \\
\text { total } \\
\mu g / L \\
\text { as Sel }\end{array}$ & $\begin{array}{c}\text { Silver, } \\
\text { total } \\
\text { ( } \mu \mathrm{g} / \mathrm{L} \\
\text { as Ag) }\end{array}$ & $\begin{array}{l}\text { Zinc, } \\
\text { total } \\
(\mu g / L \\
\text { as } \mathrm{Zn})\end{array}$ & $\begin{array}{l}\text { Linear } \\
\text { alkyl } \\
\text { sul- } \\
\text { fonate }\end{array}$ \\
\hline \multirow[b]{2}{*}{ Q3036 } & & & & & & & & & & & \\
\hline & $\begin{array}{l}3 / 2 / 81 \\
6 / 21 / 83\end{array}$ & $\begin{array}{l}<40 \\
<30\end{array}$ & $\begin{array}{l}40 \\
40\end{array}$ & $\begin{array}{r}17,000 \\
9,500\end{array}$ & $\begin{array}{r}<10 \\
60\end{array}$ & $\begin{array}{l}150 \\
240\end{array}$ & $\begin{array}{l}<1 \\
<1\end{array}$ & $\begin{array}{l}<10 \\
<10\end{array}$ & $\begin{array}{l}<30 \\
<50\end{array}$ & $\begin{array}{l}260 \\
400\end{array}$ & $\begin{array}{l}\text { neg } \\
\text { neg }\end{array}$ \\
\hline 03109 & $8 / 18 / 83$ & $<30$ & 20 & 32,000 & $<30$ & 30 & $<1$ & $<10$ & $<50$ & 80 & neg \\
\hline 03110 & $7 / 18 / 83$ & $<30$ & 20 & 14,000 & $<30$ & 2,400 & $<1$ & $<10$ & $<50$ & 40 & neg \\
\hline Q3112 & $8 / 15 / 83$ & $<30$ & 50 & 350 & $<30$ & 170 & $<1$ & $<10$ & $<50$ & 70 & neg \\
\hline 03114 & $8 / 18 / 83$ & $<30$ & 10 & 4,700 & $<30$ & 20 & $<1$ & $<10$ & $<50$ & 60 & neg \\
\hline Q3115 & $7 / 18 / 83$ & $<30$ & - & 2,900 & 350 & 270 & $<1$ & $<10$ & $<50$ & 90 & neg \\
\hline \multirow[t]{2}{*}{03117} & $2 / 9 / 81$ & $<40$ & 130 & 1,400 & $<10$ & 1,600 & $<1$ & $<10$ & $<30$ & 150 & neg \\
\hline & $8 / 15 / 83$ & $<30$ & 90 & 3,400 & 40 & 1,600 & $<1$ & $<10$ & $<50$ & 100 & neg \\
\hline \multirow[t]{2}{*}{03119} & $2 / 9 / 81$ & $<40$ & 10 & 1,300 & $<10$ & 50 & $<1$ & $<10$ & $<30$ & 1,600 & neg \\
\hline & $8 / 8 / 83$ & $<30$ & 1,800 & 18,000 & 100 & 260 & $<1$ & $<10$ & $<50$ & 5,500 & neg \\
\hline \multirow[t]{2}{*}{ Q3121 } & $2 / 27 / 81$ & $<40$ & 350 & 37,000 & $<10$ & 4,200 & $<1$ & $<10$ & $<30$ & 310 & neg \\
\hline & $6 / 13 / 83$ & $<30$ & 50 & 1,600 & $<30$ & 300 & $<1$ & $<10$ & $<50$ & 190 & neg \\
\hline \multirow[t]{2}{*}{03123} & $2 / 9 / 81$ & $<40$ & 10 & 2,600 & $<10$ & 120 & $<1$ & $<10$ & $<30$ & 1,000 & neg \\
\hline & $6 / 20 / 83$ & $<30$ & 70 & 1,200 & $<30$ & 100 & $<1$ & $<10$ & $<50$ & 380 & neg \\
\hline Q3134 & $9 / 20 / 83$ & $<30$ & 20 & 120 & $<30$ & 270 & $<1$ & $<10$ & $<50$ & 100 & neg \\
\hline 03150 & $6 / 21 / 83$ & $<30$ & 70 & 10,000 & $<30$ & 900 & $<1$ & $<10$ & $<50$ & 200 & neg \\
\hline N1429 & $9 / 27 / 83$ & $<30$ & 10 & 350 & $<30$ & 40 & $<1$ & $<10$ & $<50$ & 2,700 & neg \\
\hline \multirow[t]{2}{*}{ N1627 } & $4 / 13 / 81$ & $<50$ & 10 & 300 & $<30$ & 30 & $<1$ & $=$ & $<10$ & 110 & neg \\
\hline & $7 / 21 / 83$ & $<30$ & 30 & 1,400 & $<30$ & 90 & $<1$ & $<10$ & $<50$ & 120 & neg \\
\hline N3864 & $10 / 3 / 83$ & $<30$ & 30 & 2,800 & $<30$ & 20 & $<1$ & $<10$ & $<50$ & 50 & neg \\
\hline
\end{tabular}


Table 10.--Selected chemical analyses of ground water sampled from observation wells in Kings, Queens, and eastern Nassau Counties (continued)

\begin{tabular}{|c|c|c|c|c|c|c|c|c|c|c|c|c|c|}
\hline $\begin{array}{c}\text { Fell } \\
\text { no. }\end{array}$ & Lat & Long & $\begin{array}{l}\text { Screened } \\
\text { interval } \\
\text { (ft above } \\
\text { or below (-) } \\
\text { sea level) }\end{array}$ & Aquifer ${ }^{1}$ & $\begin{array}{l}\text { Date } \\
\text { sampled }\end{array}$ & $\begin{array}{l}\text { Spe- } \\
\text { cific } \\
\text { conduct- } \\
\text { ance } \\
(\mu s / \mathrm{cm})\end{array}$ & $\begin{array}{c}\text { pH } \\
\text { (units) }\end{array}$ & $\begin{array}{l}\text { Field } \\
\text { temp } \\
\text { (deg c) }\end{array}$ & $\begin{array}{l}\text { Color } \\
\text { (unit) }\end{array}$ & $\begin{array}{l}\text { Tur- } \\
\text { bidity } \\
\text { (NTU) }\end{array}$ & $\begin{array}{l}\text { Hard- } \\
\text { ness } \\
\text { (mg/L } \\
\text { as } \\
\mathrm{CaCO}_{3} \text { ) }\end{array}$ & $\begin{array}{l}\text { Calcium, } \\
\text { total } \\
\text { (mg/L } \\
\text { as Ca) }\end{array}$ & $\begin{array}{l}\text { Magne- } \\
\text { sium, } \\
\text { total } \\
\text { mg/L } \\
\text { as } \mathrm{Mg} \text { ) }\end{array}$ \\
\hline
\end{tabular}

$\begin{array}{llllllrrr}\text { N3867 } & 403912 & 734320 & -499 & \text { to }-511 & \text { Mag } & 10 / 4 / 83 & 51 \\ \text { N3932 } & 403751 & 734401 & -165 \text { to }-169 & \text { Jameco } & 9 / 29 / 83 & 40 \\ \text { N4026 } & 403713 & 734159 & -145 \text { to }-149 & \text { Jameco } & 9 / 28 / 83 & 61 \\ \text { N4062 } & 403621 & 734418 & -129 & \text { to } & -134 & \text { Jameco } & 9 / 27 / 83 & 175 \\ \text { N4213 } & 403912 & 734320 & -125 \text { to }-129 & \text { Jameco } & 10 / 4 / 83 & 72 \\ \text { N6581 } & 403827 & 734250 & -566 \text { to }-576 & \text { Mag } & 10 / 3 / 83 & >8,000 \\ \text { N6701 } & 403517 & 734306 & -811 \text { to }-821 & \text { Rar } & 10 / 5 / 83 & 2,600 \\ \text { N6703 } & 403517 & 734306 & -456 \text { to }-467 & \text { Mag } & 10 / 5 / 83 & >8,000 \\ \text { N6707 } & 403713 & 734159 & -487 & \text { to }-497 & \text { Mag } & 9 / 28 / 83 & 5,190 \\ \text { N6792 } & 403713 & 734159 & -42 & \text { to }-44 & \text { Upglac } & 9 / 28 / 83 & 182 \\ \text { N7161 } & 403856 & 733926 & -654 \text { to }-658 & \text { Mag } & 10 / 4 / 83 & 45 \\ \text { N8877 } & 404730 & 734231 & -59 & \text { to }-64 & \text { Upglac } & 9 / 29 / 83 & 134\end{array}$

6
4.8
6.4
6.7
5.5
5.9
7.2
6.2
6.2
7.3
4.8
6.1

$\begin{array}{lr}14.5 & 12 \\ 15 & 23 \\ 15 & 40 \\ 15 & 65 \\ 15 & 20 \\ 15 & 1,000 \\ 17 & 360 \\ 17 & 800 \\ 15.5 & 90 \\ 15 & 45 \\ 15 & 25 \\ 14.5 & 150\end{array}$

$\begin{array}{rc}12 & 6 \\ 23 & 1.3 \\ 40 & >25 \\ 65 & 75 \\ 20 & 4 \\ 000 & 31 \\ 360 & >25 \\ 800 & >25 \\ 90 & >25 \\ 45 & 4.2 \\ 25 & 12 \\ 150 & 2.5\end{array}$

8
37
18
88
16
5,200
160
1,200
1,500
76
8

$\begin{array}{cc}1.8 & 2.3 \\ 2.5 & 0.80 \\ 5.3 & 1.1 \\ 8.5 & 3.8 \\ 3.2 & 2.4 \\ -- & 96 \\ 20 & 30 \\ 220 & 450 \\ 100 & 120 \\ 18 & 3.5 \\ 1.5 & 0.2 \\ 9 . & 6.6\end{array}$

\begin{tabular}{|c|c|c|c|c|}
\hline · & $\begin{array}{c}\text { Well } \\
\text { no. }\end{array}$ & $\begin{array}{l}\text { Date } \\
\text { sampled }\end{array}$ & $\begin{array}{l}\text { Sodium, } \\
\text { total } \\
\text { (mg/L } \\
\text { as } \mathrm{Na} \text { ) }\end{array}$ & $\begin{array}{l}\text { sium, } \\
\text { total } \\
\mathrm{mg} / \mathrm{L} \\
\text { as k) }\end{array}$ \\
\hline 官 & $\begin{array}{l}\text { N3867 } \\
\text { N3932 } \\
\text { N4026 } \\
\text { N4062 } \\
\text { N4213 } \\
\text { N6581 } \\
\text { N6701 } \\
\text { N6703 } \\
\text { N6707 } \\
\text { N6792 } \\
\text { N7161 } \\
\text { N8877 }\end{array}$ & $\begin{array}{r}10 / 4 / 83 \\
9 / 29 / 83 \\
9 / 28 / 83 \\
9 / 27 / 83 \\
10 / 4 / 83 \\
10 / 3 / 83 \\
10 / 5 / 83 \\
10 / 5 / 83 \\
9 / 28 / 83 \\
9 / 28 / 83 \\
10 / 4 / 83 \\
9 / 29 / 83\end{array}$ & $\begin{array}{c}4.9 \\
4.1 \\
4.3 \\
17 \\
5.7 \\
5,100 \\
400 \\
2,600 \\
780 \\
7.5 \\
4.5 \\
5.5\end{array}$ & $\begin{array}{l}1^{.9} \\
3^{.8} \\
24^{.8} \\
25 \\
60 \\
21 \\
2 \\
2^{.6}\end{array}$ \\
\hline
\end{tabular}

Potas- Alka- Sulfate.

Chloride, Fluo-

Total Nitrogen, Nitrogen

Alka- Sulfate, Chlor

tal

dis- as nitrate, as ammonia, Arsenic, Cadmium,

solved solved

(mg/L

total

total total

$\mathrm{CaCO}_{3}$ ) as $\left.\mathrm{SO4}\right)$

as F) (mg/L) (mg/L

(mg/L

$(\mu \mathrm{g} / \mathrm{L} \quad(\mu \mathrm{g} / \mathrm{L}$

$\begin{array}{rr}14 & 8.0 \\ 14 & - \\ 26 & 5.5 \\ 34 & 3.5 \\ 20 & 6.5 \\ 96 & 4.000 \\ 38 & 45 \\ 22 & 950 \\ 6 & 230 \\ 90 & 4.5 \\ 18 & 6.5 \\ 28 & -\end{array}$

6.0
6.0
17
49
8.0
5,200
860
5,800
1,900
13
9.0
18

$<.2$
.4
.2
.3
$<.2$
.5
.4
.4
.3
.3
$<.2$
.4

32
--
42
122
47
--
1,710
9,900
3,650
134
--
--

0.03
.07
.09
.28
.07
1.3
1.4
.25
.17
.03
.40
.09

$<0.03$
$<.03$
$<.03$
$<.03$
$<.03$
$<.03$
$<.03$
$<.03$
$<.03$
$<.03$
.05
$<.03$

$\begin{array}{ll}<50 & <10 \\ <50 & <10 \\ <50 & <10 \\ <50 & <10 \\ <50 & <10 \\ <50 & <10 \\ <50 & <10 \\ <50 & <10 \\ <50 & <10 \\ <50 & <10 \\ <50 & <10 \\ <50 & <10\end{array}$


lable 1U.--belectea chemical analyses of ground water sampled trom observation wells in kings, vueens, and eastern Nassau Counties (continued)

\begin{tabular}{|c|c|c|c|c|c|c|c|c|c|c|c|}
\hline $\begin{array}{l}\text { Well } \\
\text { no. }\end{array}$ & $\begin{array}{l}\text { Date } \\
\text { sampled }\end{array}$ & $\begin{array}{l}\text { Chromium, } \\
\text { total } \\
\mu \mathrm{g} / \mathrm{L} \\
\text { as } \mathrm{Cr})\end{array}$ & $\begin{array}{l}\text { Copper, } \\
\text { total } \\
\text { ( } \mu \mathrm{g} / \mathrm{L} \\
\text { as } \mathrm{Cu})\end{array}$ & $\begin{array}{l}\text { Iron, } \\
\text { total } \\
\text { ( } \mu g / L \\
\text { as } \mathrm{Fe})\end{array}$ & $\begin{array}{l}\text { Lead, } \\
\text { total } \\
(\mu g / L \\
\text { as } \mathrm{Pb})\end{array}$ & $\begin{array}{l}\text { Manganese } \\
\text { total } \\
(\mu g / L \\
\text { as Mn) }\end{array}$ & $\begin{array}{l}\text { Mercury, } \\
\text { total } \\
\text { ( } \mu g / \mathrm{L} \\
\text { as } \mathrm{Hg})\end{array}$ & $\begin{array}{l}\text { Selenium, } \\
\text { total } \\
\mu \mathrm{g} / \mathrm{L} \\
\text { as se) }\end{array}$ & $\begin{array}{l}\text { Silver, } \\
\text { total } \\
\text { ( } \mu g / \mathrm{L} \\
\text { as Ag) }\end{array}$ & $\begin{array}{l}\text { Zinc, } \\
\text { total } \\
(\mu g / L \\
\text { as } \mathrm{Zn})\end{array}$ & $\begin{array}{l}\text { Linear } \\
\text { alkyl } \\
\text { sul- } \\
\text { fonate }\end{array}$ \\
\hline N3867 & $0 / 4 / 83$ & $<30$ & 10 & 3,700 & $<30$ & 10 & $<1$ & $<10$ & $<50$ & 50 & neg \\
\hline N3932 & $9 / 29 / 83$ & $<30$ & 40 & 3,300 & $<30$ & 10 & $<1$ & $<10$ & $<50$ & 70 & neg \\
\hline N4026 & $9 / 28 / 83$ & $<30$ & 20 & 12,000 & $<30$ & 50 & $<1$ & $<10$ & $<50$ & 70 & neg \\
\hline N4062 & $9 / 27 / 83$ & $<30$ & 10 & 18,000 & 40 & 330 & $<1$ & $<10$ & $<50$ & 90 & neg \\
\hline N4213 & $10 / 4 / 83$ & $<30$ & 20 & 950 & -- & 60 & $<1$ & $<10$ & $<50$ & 30 & neg \\
\hline N6581 & $10 / 3 / 83$ & $<30$ & 50 & 200,000 & ND & 3,800 & $<1$ & $<10$ & $<50$ & 120 & neg \\
\hline N6701 & $10 / 5 / 83$ & $<30$ & 10 & 260 & 80 & 300 & $<1$ & $<10$ & $<50$ & 1,800 & neg \\
\hline N6703 & $10 / 5 / 83$ & $<30$ & 10 & 2,100 & $<30$ & 2,200 & 1 & $<10$ & $<50$ & 40,000 & neg \\
\hline N6707 & $9 / 28 / 83$ & $<30$ & 40 & 42,000 & 130 & 1,400 & $<1$ & $<10$ & $<50$ & 4,500 & neg \\
\hline N6792 & $9 / 28 / 83$ & $<30$ & 20 & 1,900 & $<30$ & 70 & $<1$ & $<10$ & $<50$ & 250 & neg \\
\hline N7161 & $10 / 4 / 83$ & $<30$ & 10 & 5,600 & $<30$ & 20 & 1 & $<10$ & $<50$ & 40 & neg \\
\hline N8877 & 9/29/83 & $<30$ & 10 & 5,700 & 40 & 70 & $<1$ & $<10$ & $<50$ & 50 & neg \\
\hline
\end{tabular}


Table 11.--Selected chemical analyses of ground water samples from public-supply wells in Kings, Queens, and eastern Nassau Countles (sampled and analyzed by Janaica Water Supply Company)

Upglac, upper glacial; Jam, Jameco; Mag, Magothy; $\mu \mathrm{s} / \mathrm{cm}$, microsiemens per cent Imeter at 25 degrees celsius; $\mathrm{mg} / \mathrm{L}$, milligrams per 11ter; $\mu \mathrm{g} / \mathrm{L}$, micrograms per liter; deg c, degrees celsius; --, analysis not avallable; <, less than NTU, Nephelometric turbidity unit.]

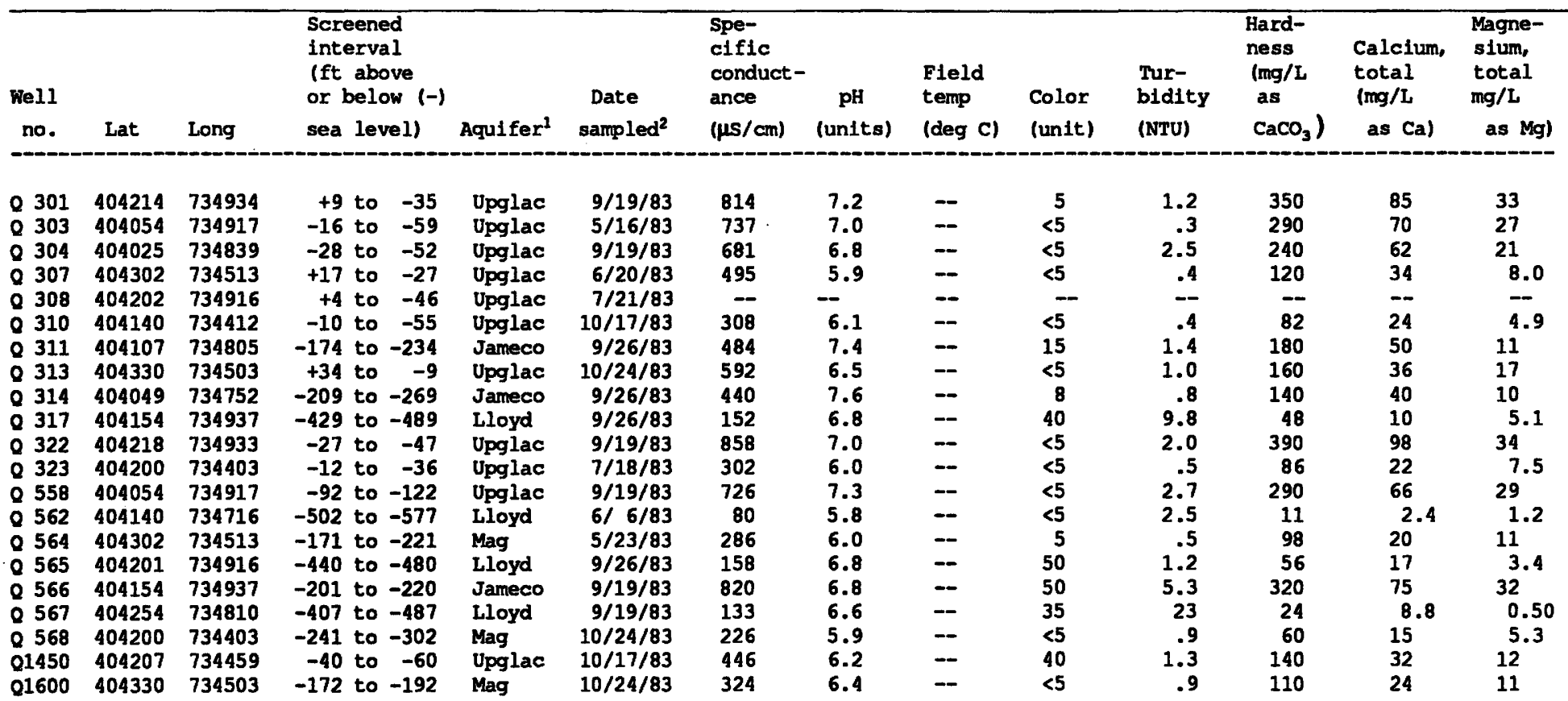

$\begin{array}{ll}1 \text { Upglac } & \text { upper glacial aquifer } \\ \text { Jameco } & \text { Jameco aquifer }\end{array}$

$\begin{array}{ll}\text { Jameco } & \text { Jameco aquifer } \\ \text { Lloyd } & \text { Lloyd aquifer }\end{array}$

Lloyd Magothy aquifer

Rar Raritan confining unit

2 Wells were sampled by the U.S. Geological Survey and ranged from 2 to 32 Inches In diameter Generally, the smaller diameter wells are Geological Survey observation wells; those of larger diameter are industrial or abandoned

public-supply wells. Sample-collection procedures were determined mainly by well diameter and depth to water Normally, where the depth to water was $25 \mathrm{ft}$ or less, a centrifugal pump was used; otherwise a

submersible pump was used. In places where both centrifugal and submersible pumps were impractical, the

samples were bailed. The volume of water standing in the well casing was evacuated at least three times, and specific conductance was monitored until stable before sampling was begun.

All samples were stored and preserved with appropriate chemical reagents as described by the

Bureau of Water Supply Laboratory (New York C1ty Department of Environmental Protection, written commun..

1983) Samples were analyzed by the Bureau of Water Supply Laboratory according to methods prescribed by

the American Public Health Association (1976). 
Table 11.--Selected chemical analyses of ground water sampled from public-supply wells in Kings, Queens, and eastern Nassau Counties (sampled and analyzed by Jamaica Water supply Company) (continued)

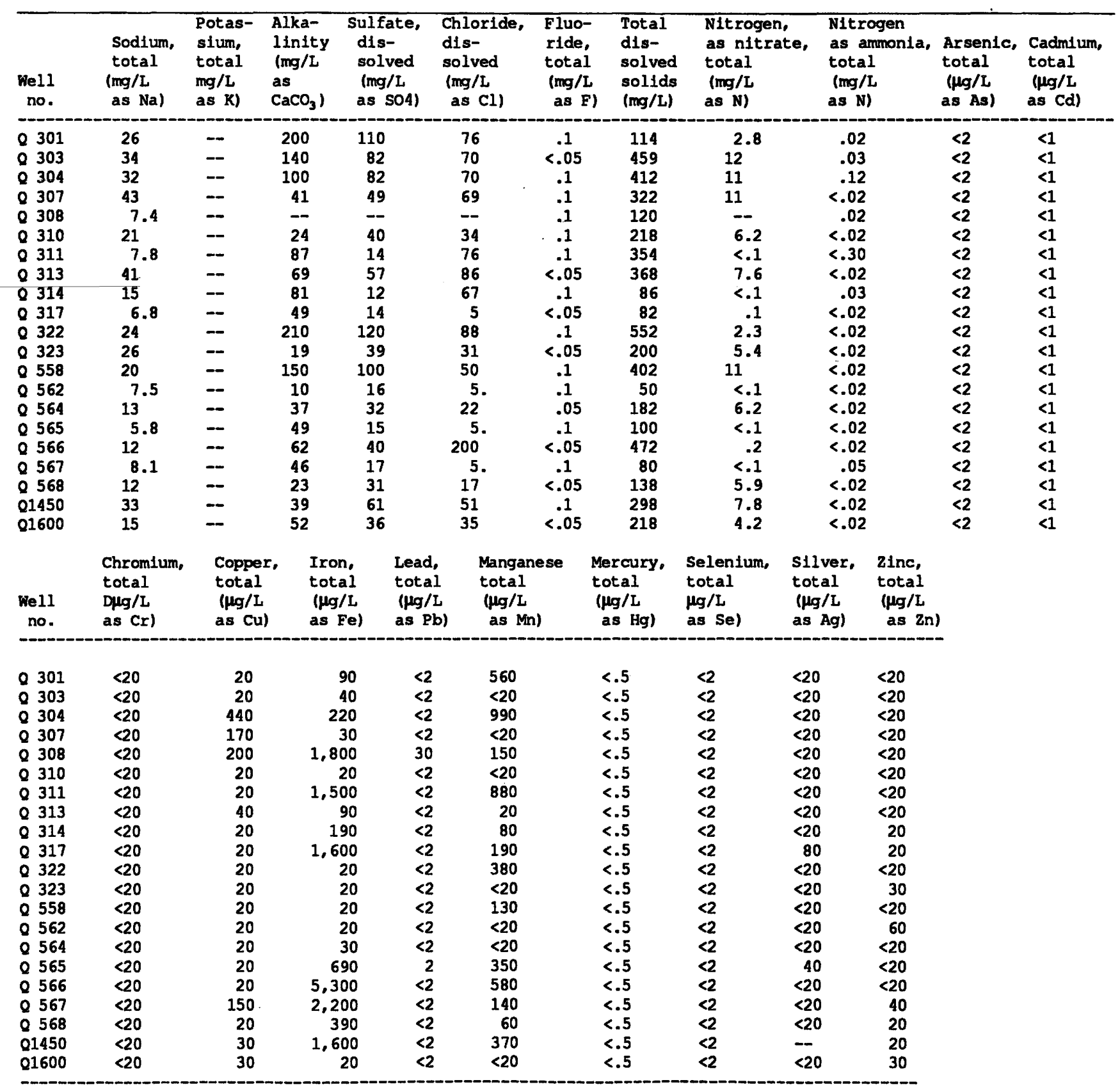


Table 11.--Selected chemical analyses of ground water sampled from public-supply wells in Kings, Oueens,

and eastern Nassau Counties (sampled and analyzed by Jamaica Mater supply Company) (cont inued)

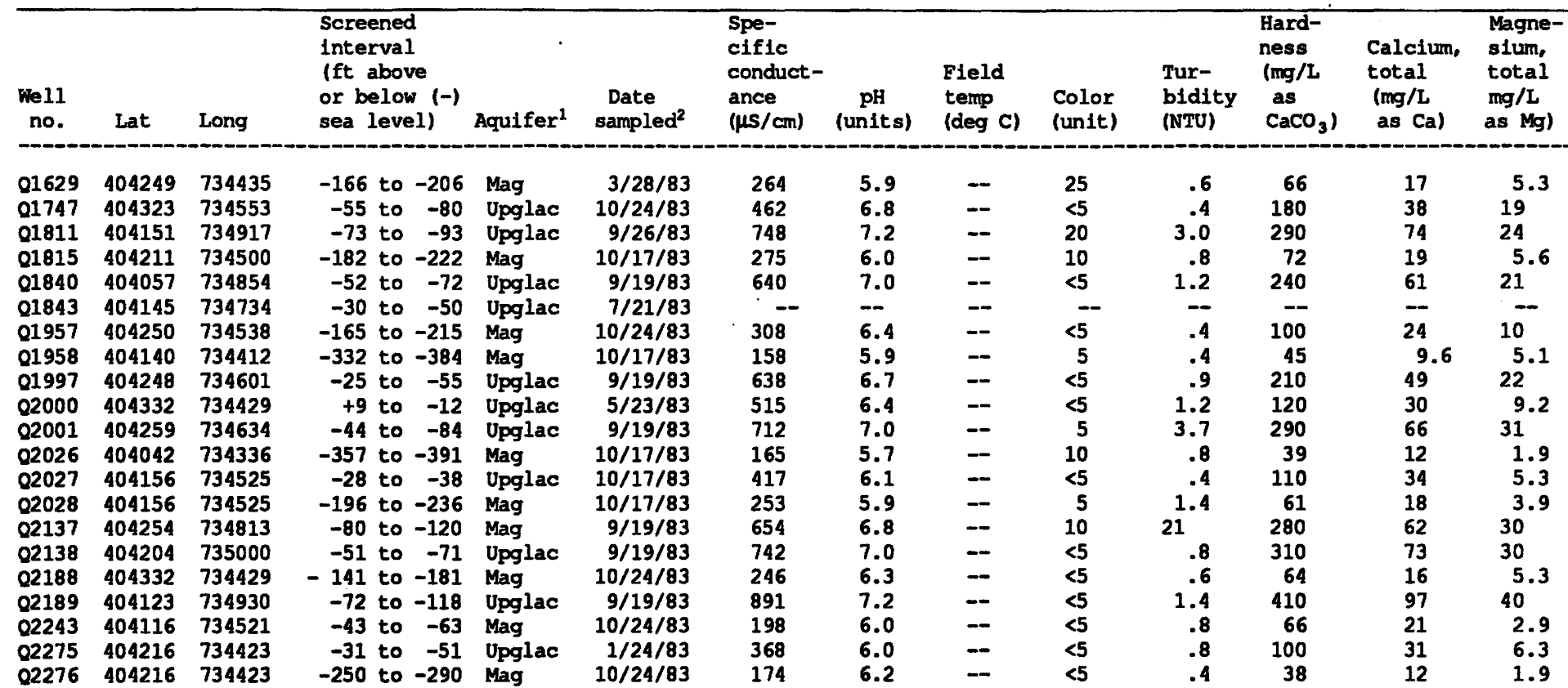

\begin{tabular}{|c|c|c|c|c|c|c|c|c|c|c|c|}
\hline $\begin{array}{l}\text { Well } \\
\text { no. }\end{array}$ & $\begin{array}{l}\text { Sodium, } \\
\text { total } \\
\text { (mg/L } \\
\text { as } \mathrm{Na} \text { ) }\end{array}$ & $\begin{array}{l}\text { Potas- } \\
\text { sium, } \\
\text { total } \\
\mathrm{mg} / \mathrm{L} \\
\text { as } \mathrm{K} \text { ) }\end{array}$ & $\begin{array}{l}\text { Alka- } \\
\text { linity } \\
\text { (mg/L } \\
\text { as } \\
\mathrm{CaCO}_{3} \text { ) }\end{array}$ & $\begin{array}{l}\text { Sulfate, } \\
\text { dis- } \\
\text { solved } \\
\text { (mg/L } \\
\text { as S04) }\end{array}$ & $\begin{array}{l}\text { Chloride, } \\
\text { dis- } \\
\text { solved } \\
\text { (mg/L } \\
\text { as C1) }\end{array}$ & $\begin{array}{l}\text { Fluo- } \\
\text { ride, } \\
\text { total } \\
\text { (mg/L } \\
\text { as F) }\end{array}$ & $\begin{array}{l}\text { Total } \\
\text { dis- } \\
\text { solved } \\
\text { sollds } \\
\text { (mg/L) }\end{array}$ & $\begin{array}{l}\text { Nitrogen, } \\
\text { as nitrate, } \\
\text { total } \\
\text { (mg/L } \\
\text { as } N \text { ) }\end{array}$ & $\begin{array}{l}\text { Nitrogen } \\
\text { as ammonia, } \\
\text { total } \\
\text { (mg/L } \\
\text { as } \mathrm{N} \text { ) }\end{array}$ & $\begin{array}{l}\text { Arsenic, } \\
\text { total } \\
\text { ( } \mu g / L \\
\text { as As) }\end{array}$ & $\begin{array}{l}\text { Cadinium, } \\
\text { total } \\
(\mu \mathrm{g} / \mathrm{L} \\
\text { as Cd) }\end{array}$ \\
\hline Q1629 & 16 & -- & 25 & 26 & 29 & .1 & -- & 7.2 & $<.02$ & $<2$ & $<1$ \\
\hline 01747 & 3 & -- & 94 & 43 & 50 & $<.05$ & 288 & 3.4 & $<.02$ & $<2$ & $<1$ \\
\hline Q1811 & 32 & -- & 190 & 85 & 60 & .1 & 464 & 5.3 & .08 & $<2$ & $<1$ \\
\hline Q1815 & 14 & -- & 20 & 43 & 24 & $<.05$ & 172 & 3.4 & $<.02$ & $<2$ & $<1$ \\
\hline Q1840 & 32 & -- & 130 & 85 & 64 & .1 & 402 & 8.8 & $<.02$ & $<2$ & $<1$ \\
\hline Q1843 & 36 & - & - & -- & -- & .1 & 476 & -- & .20 & $<2$ & $<1$ \\
\hline Q1957 & 15 & -- & 45 & 36 & 35 & $<.05$ & 197 & 6.1 & $<.02$ & $<2$ & $<1$ \\
\hline Q1958 & 7.6 & - & 28 & 30 & 12 & .1 & 104 & .4 & $<.02$ & $<.2$ & $<1$ \\
\hline Q1997 & 31 & -- & 110 & 70 & 68 & .1 & 378 & 5.2 & $<.02$ & $<2$ & $<1$ \\
\hline 02000 & 30 & -- & 84 & 49 & 52 & $<.02$ & 140 & 8.2 & .03 & $<2$ & $<1$ \\
\hline Q2001 & 22 & -- & 170 & 85 & 67 & .1 & 424 & 1.1 & .13 & $<2$ & $<1$ \\
\hline Q2026 & 9.6 & -- & 6. & 36 & 9. & $<.05$ & 192 & $<.1$ & $<.02$ & $<2$ & $<1$ \\
\hline Q2027 & 30 & -- & 44 & 53 & 41 & .1 & 276 & 10 & $<.02$ & $<2$ & $<1$ \\
\hline Q2028 & 15 & -- & 11 & 48 & 28 & .1 & 162 & 3.4 & $<.02$ & $<2$ & $<1$ \\
\hline 02137 & 14 & -- & 150 & 95 & 58 & $<.05$ & 404 & $<.1$ & $<.02$ & $<2$ & $<1$ \\
\hline 02138 & 23 & -- & 170 & 95 & 58 & .1 & 196 & 4.2 & $<.02$ & $<2$ & $<1$ \\
\hline 02188 & 11 & -- & 25 & 28 & 21 & .1 & 98 & 6.8 & $<.02$ & $<2$ & $<1$ \\
\hline$Q 2189$ & 28 & -- & 160 & 90 & 160 & $<.05$ & 540 & 8.2 & .03 & $<2$ & $<1$ \\
\hline Q2243 & 19 & - & 23 & 27 & 26 & .1 & 124 & 3.6 & $<.02$ & $<2$ & $<1$ \\
\hline 02275 & 6 & -- & 26 & 52 & 44 & $<.05$ & 206 & 7.6 & $<.02$ & $<2$ & $<1$ \\
\hline Q2276 & 8.5 & -- & 21 & 16 & 12 & $<.05$ & 112 & 6.0 & $<.02$ & $<2$ & $<1$ \\
\hline
\end{tabular}


Table 11.--Selected chemical analyses of ground water sampled from public-supply wells in Kings, Queens, and eastern Nassau Counties (sampled and analyzed by Jamaica

\begin{tabular}{|c|c|c|c|c|c|c|c|c|c|}
\hline $\begin{array}{l}\text { Well } \\
\text { no. }\end{array}$ & $\begin{array}{l}\text { Chromium, } \\
\text { total } \\
\text { D }{ }^{\prime} / \mathrm{L} \\
\text { as } \mathrm{Cr} \text { ) }\end{array}$ & $\begin{array}{l}\text { Copper, } \\
\text { total } \\
\text { ( } \mu \mathrm{g} / \mathrm{L} \\
\text { as } \mathrm{Cu} \text { ) }\end{array}$ & $\begin{array}{l}\text { Iron, } \\
\text { total } \\
\text { ( } \mu \text { g/L } \\
\text { as } \mathrm{Fe})\end{array}$ & $\begin{array}{l}\text { Lead, } \\
\text { total } \\
(\mu g / \mathrm{L} \\
\text { as } \mathrm{Pb})\end{array}$ & $\begin{array}{l}\text { Manganese } \\
\text { total } \\
(\mu g / L \\
\text { as } \mathrm{M})\end{array}$ & $\begin{array}{l}\text { Mercury, } \\
\text { total } \\
\text { ( } \mu g / L \\
\text { as } \mathrm{Hg})\end{array}$ & $\begin{array}{l}\text { Selenium, } \\
\text { total } \\
\mu g / L \\
\text { as Se) }\end{array}$ & $\begin{array}{l}\text { Silver, } \\
\text { total } \\
\text { ( } \mu g / L \\
\text { as } \mathrm{Ag})\end{array}$ & $\begin{array}{l}\text { Zinc, } \\
\text { total } \\
\text { ( } \mu \text { g/L } \\
\text { as } \mathrm{Zn})\end{array}$ \\
\hline 01629 & $<20$ & 20 & 20 & $<2$ & $<20$ & $<.5$ & $<2$ & $<20$ & $<20$ \\
\hline 01747 & $<20$ & 20 & 20 & $<2$ & $<20$ & $<.5$ & $<2$ & $<20$ & $<20$ \\
\hline Q1811 & $<20$ & 40 & 50 & $<2$ & 490 & $<.5$ & $<2$ & $<20$ & $<20$ \\
\hline 01815 & $<20$ & 20 & 20 & $<2$ & $<20$ & $<.5$ & $<2$ & $<20$ & $<20$ \\
\hline Q1840 & $<20$ & 20 & 20 & $<2$ & 160 & $<.5$ & $<2$ & $<20$ & $<20$ \\
\hline Q1843 & $<20$ & 20 & 60 & $<2$ & 40 & $<.5$ & $<2$ & $<20$ & 70 \\
\hline Q1957 & $<20$ & 20 & 20 & $<2$ & 70 & $<.5$ & $<2$ & $<20$ & $<20$ \\
\hline Q1958 & $<20$ & 20 & 20 & 2 & $<20$ & $<.5$ & $<2$ & $<20$ & $<20$ \\
\hline Q1997 & $<20$ & 20 & 40 & $<2$ & $<20$ & $<.5$ & $<2$ & $<20$ & $<20$ \\
\hline 02000 & $<20$ & 90 & 20 & $<2$ & $<20$ & $<.5$ & $<2$ & $<20$ & $<20$ \\
\hline Q2001 & $<20$ & 20 & 530 & $<2$ & 340 & $<.5$ & $<2$ & $<20$ & $<20$ \\
\hline Q2026 & $<20$ & 60 & 570 & $<2$ & 120 & $<.5$ & $<2$ & $<20$ & 20 \\
\hline 02027 & $<20$ & 30 & 60 & $<2$ & $<20$ & $<.5$ & $<2$ & $<20$ & $<20$ \\
\hline 02028 & $<20$ & 40 & 930 & $<2$ & 160 & $<.5$ & $<2$ & $<20$ & $<20$ \\
\hline 02137 & $<20$ & 20 & 2,200 . & $<2$ & 570 & $<.5$ & $<2$ & $<20$ & $<20$ \\
\hline Q2138 & $<20$ & 30 & 20 & 5 & 60 & $<.5$ & $<2$ & $<20$ & 50 \\
\hline 02188 & $<20$ & 60 & 20 & 4 & $<20$ & $<.5$ & $<2$ & $<20$ & $<20$ \\
\hline 02189 & $<20$ & 20 & 150 & $<2$ & 160 & $<.5$ & $<2$ & $<20$ & $<20$ \\
\hline 02243 & $<20$ & 20 & 70 & $<2$ & 170 & $<.5$ & $<2$ & $<20$ & 60 \\
\hline 02275 & $<20$ & 40 & 40 & $<2$ & $<20$ & $<.5$ & $<2$ & $<20$ & $<20$ \\
\hline 02276 & $<20$ & 20 & 20 & 3 & $<20$ & $<.5$ & $<2$ & $<20$ & $<20$ \\
\hline
\end{tabular}


Table 11.--Selected chemical analyses of ground water sampled from public-supply wells in Kings, Queens, and eastern Nassau Counties (sampled and analyzed by Jamaica Water Supply Company) (continued)

\begin{tabular}{|c|c|c|c|c|c|c|c|c|c|c|c|c|c|c|}
\hline $\begin{array}{c}\text { Well } \\
\text { no. }\end{array}$ & Lat & Long & $\begin{array}{l}\text { Scr } \\
\text { inte } \\
\text { (ft } \\
\text { or } \\
\text { sea }\end{array}$ & $\begin{array}{l}\text { eened } \\
\text { erval } \\
\text { above } \\
\text { below (-) } \\
\text { level) }\end{array}$ & Aquifer ${ }^{2}$ & $\begin{array}{l}\text { Date } \\
\text { sampled }\end{array}$ & $\begin{array}{l}\text { Spe- } \\
\text { cific } \\
\text { conduct- } \\
\text { ance } \\
(\mu \mathrm{cm} / \mathrm{cm})\end{array}$ & $\begin{array}{c}\mathrm{pH} \\
\text { (units) }\end{array}$ & $\begin{array}{l}\text { Field } \\
\text { temp } \\
\text { (deg C) }\end{array}$ & $\begin{array}{l}\text { Color } \\
\text { (unit) }\end{array}$ & $\begin{array}{l}\text { Tur- } \\
\text { bIdity } \\
\text { (NTU) }\end{array}$ & $\begin{array}{l}\text { Hard- } \\
\text { ness } \\
(\mathrm{mg} / \mathrm{L} \\
\mathrm{as} \\
\left.\mathrm{CaCO}_{3}\right)\end{array}$ & $\begin{array}{l}\text { Calcium, } \\
\text { total } \\
\text { (mg/L } \\
\text { as Ca) }\end{array}$ & $\begin{array}{l}\text { Magne- } \\
\text { sium, } \\
\text { total } \\
\text { mg/L } \\
\text { as } \mathrm{Mg} \text { ) }\end{array}$ \\
\hline $\begin{array}{l}02299 \\
02300\end{array}$ & 404225 & 734503 & -42 & to -62 & Upglac & $7 / 18 / 83$ & 416 & 5.8 & $=$ & $<5$ & .5 & 120 & 36 & 6.8 \\
\hline $\begin{array}{l}02300 \\
02332\end{array}$ & $\begin{array}{l}404224 \\
404204\end{array}$ & $\begin{array}{l}734503 \\
735000\end{array}$ & $\begin{array}{l}-179 \\
-158\end{array}$ & $\begin{array}{l}\text { to }-219 \\
\text { to }-188\end{array}$ & $\begin{array}{l}\text { Mag } \\
\text { Jameco }\end{array}$ & $\begin{array}{l}7 / 7 / 83 \\
9 / 26 / 83\end{array}$ & 522 & -- & -- & -2 & $-\overline{7}$ & 230 & $\overline{54}$ & $\overline{23}$ \\
\hline 02343 & $\begin{array}{l}704249 \\
404249\end{array}$ & 734406 & -125 & to -165 & Mag & $5 / 23 / 83$ & 274 & 6.0 & - & 5 & 1.2 & 79 & 17 & 8.5 \\
\hline 02362 & 404320 & 734818 & -138 & to -205 & Mag & $10 / 17 / 83$ & 484 & 7.1 & -- & 5 & .3 & 190 & 47 & 17 \\
\hline 02363 & 404343 & 734831 & -56 & to -66 & Mag & $9 / 19 / 83$ & 759 & 6.6 & -- & $<5$ & 1.3 & 260 & 56 & 29 \\
\hline 02373 & 404323 & 734838 & -69 & to -84 & Mag & $9 / 19 / 83$ & 856 & 7.0 & -- & $<5$ & .6 & 370 & 88 & 37 \\
\hline 02374 & 404323 & 734838 & -145 & to -180 & Mag & $10 / 17 / 83$ & 472 & 7.0 & -- & $<5$ & .6 & 190 & 45 & 18 \\
\hline 02408 & 404329 & 734827 & -52 & to -72 & Mag & 9/19/83 & 706 & 6.9 & -- & $<5$ & .9 & 270 & 66 & 25 \\
\hline 02409 & 404329 & 734827 & -142 & to -182 & Mag & $10 / 17 / 83$ & 440 & 6.6 & -- & $<5$ & .6 & 160 & 34 & 18 \\
\hline 02432 & 404247 & 734603 & -178 & to -218 & Mag & $10 / 17 / 83$ & 352 & 6.6 & - & $<5$ & .2 & 120 & 27 & 12 \\
\hline 02435 & 404351 & 734448 & -150 & to -190 & Mag & $6 / 6 / 83$ & 292 & 6.2 & - & $<5$ & 1.8 & 90 & 22 & 8.3 \\
\hline 02442 & 404135 & 734402 & -46 & to -56 & Mag & $7 / 7 / 83$ & - & -- & -- & -- & -- & -- & - & -- \\
\hline 02443 & 404135 & 734402 & -273 & to -313 & Mag & $10 / 17 / 83$ & 169 & 5.9 & -- & $<5$ & .9 & 43 & 10 & 4.4 \\
\hline 02955 & 404040 & 734450 & -385 & to -420 & Mag & $10 / 24 / 83$ & 145 & 5.8 & - & 5 & .8 & 28 & 8.0 & 1.9 \\
\hline 03014 & 404309 & 734700 & -159 & to -209 & Mag & $10 / 17 / 83$ & 385 & 7.0 & -- & $<5$ & .5 & 140 & 29 & 16 \\
\hline 03034 & 404234 & 734553 & -184 & to -224 & Mag & $10 / 17 / 83$ & 352 & 6.2 & -- & $<5$ & .4 & 110 & 25 & 10 \\
\hline 03062 & 404059 & 734508 & -357 & to -397 & Mag & $10 / 17 / 83$ & 92 & 6.0 & -- & $<5$ & .6 & 27 & 7.2 & 2.2 \\
\hline 03083 & 404056 & 734406 & -271 & to -319 & Mag & $7 / 18 / 83$ & 188 & 5.6 & -- & $<5$ & .6 & 110 & 13 & 19 \\
\hline N 11 & 404224 & 734238 & -325 & to -359 & Mag & $1 / 31 / 83$ & 211 & 5.6 & - & $<5$ & .3 & 61 & 14 & 5.8 \\
\hline N 12 & 404219 & 734240 & -318 & to -376 & Mag & $6 / 6 / 83$ & 151 & 5.8 & -- & $<5$ & 1.6 & 40 & 10 & 3.6 \\
\hline
\end{tabular}

\begin{tabular}{|c|c|c|c|c|c|c|c|c|c|c|c|}
\hline $\begin{array}{l}\text { nell } \\
\text { no. }\end{array}$ & $\begin{array}{l}\text { Sodium, } \\
\text { total } \\
\text { (mg/L } \\
\text { as } \mathrm{Na} \text { ) }\end{array}$ & $\begin{array}{l}\text { Potas- } \\
\text { sium, } \\
\text { total } \\
\text { mg/L } \\
\text { as } \mathrm{K} \text { ) }\end{array}$ & $\begin{array}{l}\text { Alka- } \\
\text { linity } \\
\text { (mg/L } \\
\text { as } \\
\mathrm{CaCO}_{3} \text { ) }\end{array}$ & $\begin{array}{l}\text { Sulfate, } \\
\text { dis- } \\
\text { solved } \\
\text { (mg/L } \\
\text { as S04) }\end{array}$ & $\begin{array}{l}\text { Chloride, } \\
\text { dis- } \\
\text { solved } \\
\text { (mg/L } \\
\text { as Cl) }\end{array}$ & $\begin{array}{l}\text { Fluo- } \\
\text { ride, } \\
\text { total } \\
\text { (mg/L } \\
\text { as F) }\end{array}$ & $\begin{array}{l}\text { Total } \\
\text { dis- } \\
\text { solved } \\
\text { solids } \\
\text { (mg/L) }\end{array}$ & $\begin{array}{l}\text { Nitrogen, } \\
\text { as nitrate, } \\
\text { total } \\
\text { (mg/L } \\
\text { as } \mathrm{N} \text { ) }\end{array}$ & $\begin{array}{l}\text { Nitrogen } \\
\text { as ammonia, } \\
\text { total } \\
\text { (mg/L } \\
\text { as N) }\end{array}$ & $\begin{array}{l}\text { Arsentc, } \\
\text { total } \\
\text { ( } \mu \text { g/L } \\
\text { as As) }\end{array}$ & $\begin{array}{l}\text { Cadmium, } \\
\text { total } \\
(\mu \mathrm{g} / \mathrm{L} \\
\text { as Cd) }\end{array}$ \\
\hline Q2299 & 26 & -- & 30 & 51 & 45 & $<.05$ & 246 & 10 & $<.02$ & $<2$ & $<1$ \\
\hline Q2300 & 12 & -- & - & - & - & .1 & 34 & -- & $<.02$ & $<2$ & $<1$ \\
\hline $\mathbf{0 2 3 3 2}$ & 10 & -- & 140 & 72 & 28 & $<.05$ & 260 & .7 & $<.02$ & $<2$ & $<1$ \\
\hline 02343 & 13 & -- & 19 & 26 & 23 & .1 & 196 & 9.8 & $<.02$ & $<2$ & $<1$ \\
\hline Q2362 & 14 & -- & 110 & 72 & 11 & .1 & 302 & 2.5 & $<.02$ & $<2$ & $<1$ \\
\hline 02363 & 36 & -- & 110 & 90 & 100 & .1 & 426 & 6.6 & $<.02$ & $<2$ & $<1$ \\
\hline Q2373 & 22 & -- & 210 & 110 & 84 & .1 & 522 & 2.6 & .07 & $<2$ & $<1$ \\
\hline Q2374 & 13 & -- & 120 & 61 & 22 & .1 & 292 & 4.0 & $<.02$ & $<2$ & $<1$ \\
\hline 02408 & 28 & -- & 140 & 82 & 66 & $<.05$ & 406 & 6.2 & $<.02$ & $<2$ & $<1$ \\
\hline 02409 & 15 & -- & 74 & 47 & 35 & .1 & 264 & 4.2 & $<.02$ & $<2$ & $<1$ \\
\hline 02432 & 16 & -- & 63 & 39 & 31 & .05 & 212 & 3.2 & .11 & $<2$ & $<1$ \\
\hline 02435 & 11 & -- & 25 & 36 & 33 & .1 & 188 & 4.2 & $<.02$ & $<2$ & $<1$ \\
\hline 02442 & 26 & - & - & - & - & .05 & 136 & - & $<.02$ & $<2$ & $<1$ \\
\hline 22443 & 10 & -- & 11 & 29 & 16 & .07 & 112 & $<.1$ & $<.02$ & $<2$ & $<1$ \\
\hline 02955 & 6.5 & - & 15 & 26 & 10 & .1 & 176 & $<.1$ & $<.02$ & $<2$ & $<1$ \\
\hline 03014 & 12 & -- & 83 & 48 & 27 & $<.05$ & 246 & 1.2 & $<.02$ & $<2$ & $<1$ \\
\hline 03034 & 18 & -- & 41 & 48 & 34 & .1 & 216 & 5.2 & $<.02$ & $<2$ & . $<1$ \\
\hline 03062 & 5.8 & -- & 11 & 18 & 6.0 & $<.05$ & 72 & .1 & $<.02$ & $<2$ & $<1$ \\
\hline 03083 & 11 & -- & 11 & 54 & 15 & .07 & 244 & $<.1$ & $<.02$ & $<2$ & $<1$ \\
\hline N 11 & & -- & 11 & 33 & 14 & .1 & 224 & 5.8 & $<.02$ & $<2$ & $<1$ \\
\hline N 12 & 9.7 & -- & 25 & 24 & 14 & $<.05$ & 84 & 3.0 & $<.02$ & $<2$ & $<1$ \\
\hline
\end{tabular}


Table 11.--Selected chemical analyses of ground water sampled from public-supply wells in Kings, Queens, and eastern Nassau Counties (sampled and analyzed by Jamaica Water Supply Company) (continued)

\begin{tabular}{|c|c|c|c|c|c|c|c|c|c|}
\hline $\begin{array}{l}\text { Nell } \\
\text { no. }\end{array}$ & $\begin{array}{l}\text { Chromium, } \\
\text { total } \\
\text { D } \mu g / L \\
\text { as Cr) }\end{array}$ & $\begin{array}{l}\text { Copper, } \\
\text { total } \\
(\mu g / L \\
\text { as Cu) }\end{array}$ & $\begin{array}{l}\text { Iron, } \\
\text { total } \\
(\mu g / L \\
\text { as } \mathrm{Fe})\end{array}$ & $\begin{array}{l}\text { Lead, } \\
\text { total } \\
(\mu \mathrm{g} / \mathrm{L} \\
\mathrm{as} \mathrm{Pb})\end{array}$ & $\begin{array}{l}\text { Manganese } \\
\text { total } \\
(\mu \mathrm{gg} / \mathrm{L} \\
\text { as } \mathrm{Mn})\end{array}$ & $\begin{array}{l}\text { Mercury, } \\
\text { total } \\
\text { ( } \mu g / \mathrm{L} \\
\text { as } \mathrm{Hg})\end{array}$ & $\begin{array}{l}\text { Selenium, } \\
\text { total } \\
\mu \mathrm{g} / \mathrm{L} \\
\text { as } \mathrm{Se})\end{array}$ & $\begin{array}{l}\text { Silver, } \\
\text { total } \\
(\mu g / L \\
\text { as Ag) }\end{array}$ & $\begin{array}{l}\text { Z1nc, } \\
\text { total } \\
\text { ( } \mu g / L \\
\text { as } \mathrm{Zn})\end{array}$ \\
\hline 02299 & $<20$ & 30 & 20 & 5 & $<20$ & $<.5$ & $<2$ & $<20$ & 30 \\
\hline 02300 & $<20$ & 30 & 20 & $<2$ & $<20$ & $<.5$ & $<2$ & $<20$ & 70 \\
\hline Q2332 & $<20$ & 20 & 560 & $<2$ & 120 & $<.5$ & $<2$ & $<20$ & $<20$ \\
\hline 02343 & $<20$ & 80 & 20 & $<2$ & $<20$ & $<.5$ & $<2$ & $<20$ & $<20$ \\
\hline Q2362 & $<20$ & 30 & 20 & 2 & $<20$ & $<.5$ & $<2$ & $<20$ & $<20$ \\
\hline 22363 & $<20$ & 20 & 20 & $<2$ & $<20$ & $<.5$ & $<2$ & $<20$ & $<20$ \\
\hline 02373 & $<20$ & 20 & 20 & $<2$ & 160 & $<.5$ & $<2$ & $<20$ & $<20$ \\
\hline 02374 & $<20$ & 20 & 30 & $<2$ & $<20$ & $<.5$ & $<2$ & $<20$ & $<20$ \\
\hline 22408 & $<20$ & 20 & 20 & $<2$ & $<20$ & $<.5$ & $<2$ & $<20$ & $<20$ \\
\hline 02409 & $<20$ & 20 & 20 & $<2$ & $<20$ & $<.5$ & $<2$ & $<20$ & $<20$ \\
\hline 02432 & $<20$ & 20 & 20 & $<2$ & $<20$ & $<.5$ & $<2$ & $<20$ & $<20$ \\
\hline 02435 & $<20$ & 20 & 20 & $<2$ & $<20$ & $<.5$ & $<2$ & $<20$ & $<20$ \\
\hline 02442 & $<20$ & 20 & 60 & $<2$ & $<20$ & $<.5$ & $<2$ & $<20$ & $<20$ \\
\hline 02443 & $<20$ & 20 & 700 & $<2$ & 100 & $<.5$ & $<2$ & $<20$ & $<20$ \\
\hline 02955 & $<20$ & 20 & 460 & $<2$ & 100 & $<.5$ & $<2$ & $<20$ & $<20$ \\
\hline Q3014 & $<20$ & 40 & 60 & $<2$ & $<20$ & $<.5$ & $<2$ & $<20$ & $<20$ \\
\hline 03034 & $<20$ & 20 & 20 & $<2$ & $<20$ & $<.5$ & $<2$ & $<20$ & $<20$ \\
\hline Q3062 & $<20$ & 20 & 40 & $<2$ & $<20$ & $<.5$ & $<2$ & $<20$ & $<20$ \\
\hline Q3083 & $<20$ & 30 & 2,200 & $<2$ & 210 & $<.5$ & $<2$ & $<20$ & $<20$ \\
\hline N 11 & $<20$ & 30 & 20 & $<2$ & $<20$ & .5 & $<2$ & $<20$ & $<20$ \\
\hline N 12 & $<20$ & 30 & 50 & 4 & $<20$ & $<.5$ & $<2$ & $<20$ & $<20$ \\
\hline
\end{tabular}


Table 11.--Selected chemical analyses of ground water sampled from public-supply wells in Kings, Queens, and eastern Nassau Counties (sampled and analyzed by Jamaica Water Supply Company) (cont inued)

\begin{tabular}{|c|c|c|c|c|c|c|c|c|c|c|c|c|c|}
\hline $\begin{array}{l}\text { Well } \\
\text { no. }\end{array}$ & Lat & Long & $\begin{array}{l}\text { Screened } \\
\text { interval } \\
\text { (ft above } \\
\text { or below (-) } \\
\text { sea level) }\end{array}$ & Aquifer ${ }^{1}$ & $\begin{array}{l}\text { Date } \\
\text { sampled }\end{array}$ & $\begin{array}{l}\text { Spr- } \\
\text { cific } \\
\text { conduct- } \\
\text { ance } \\
(\mu \mathrm{s} / \mathrm{cm})\end{array}$ & $\begin{array}{c}\mathrm{pH} \\
\text { (units) }\end{array}$ & $\begin{array}{l}\text { Field } \\
\text { temp } \\
\text { (deg c) }\end{array}$ & $\begin{array}{l}\text { Color } \\
\text { (unit) }\end{array}$ & $\begin{array}{l}\text { Tur- } \\
\text { bidity } \\
\text { (NTU) }\end{array}$ & $\begin{array}{l}\text { Hard- } \\
\text { ness } \\
\text { (mg/L } \\
\text { as } \\
\left.\mathrm{CaCO}_{3}\right)\end{array}$ & $\begin{array}{l}\text { Calcium, } \\
\text { total } \\
\text { (mg/L } \\
\text { as } \mathrm{Ca} \text { ) }\end{array}$ & $\begin{array}{l}\text { Magne- } \\
\text { sium, } \\
\text { total } \\
\mathrm{mg} / \mathrm{L} \\
\text { as } \mathrm{Mg} \text { ) }\end{array}$ \\
\hline
\end{tabular}

$\begin{array}{lrll}N & 13 & 404214 & 734241 \\ N & 14 & 404411 & 734137 \\ N & 17 & 404437 & 734023 \\ N & 693 & 404229 & 734244 \\ \text { N1958 } & 404426 & 734148 \\ \text { N2115 } & 404106 & 734329 \\ \text { N2413 } & 404125 & 734210 \\ \text { N2414 } & 404124 & 734210 \\ \text { N3720 } & 404112 & 734041 \\ \text { N4077 } & 404323 & 734138 \\ \text { N4298 } & 404323 & 734138 \\ \text { N4390 } & 404514 & 734121 \\ \text { N4512 } & 404100 & 734122 \\ \text { N5155 } & 404238 & 734203 \\ \text { N5156 } & 404238 & 734203 \\ \text { N6744 } & 404238 & 734205 \\ \text { N6745 } & 404239 & 734202 \\ \text { N7445 } & 404514 & 734121 \\ \text { N7482 } & 404109 & 734329 \\ \text { N7649 } & 404344 & 734121 \\ \text { N7650 } & 404344 & 734121\end{array}$

$\begin{array}{rlllr}-182 & \text { to }-240 & \text { Mag } & 7 / 18 / 83 & 297 \\ +14 \text { to } & -7 & \text { Upglac } & 7 / 18 / 83 & 308 \\ -304 \text { to }-364 & \text { Mag } & 1 / 31 / 83 & 28 \\ -18 \text { to }-43 & \text { Upglac } & 3 / 28 / 83 & 420 \\ -551 \text { to }-611 & \text { Lloyd } & 1 / 31 / 83 & \\ -36 \text { to }-56 & \text { Upglac } & 7 / 18 / 83 & 410 \\ -427 \text { to }-457 & \text { Mag } & 7 / 18 / 83 & 12 \\ -18 \text { to }-38 & \text { Upglac } & 3 / 28 / 83 & 204 \\ -443 \text { to }-483 & \text { Mag } & 1 / 31 / 83 & 63 \\ +15 \text { to }-5 & \text { Upglac } & 3 / 28 / 83 & 226 \\ -264 \text { to }-299 & \text { Mag } & 1 / 31 / 83 & 213 \\ -137 \text { to }-172 & \text { Mag } & 1 / 31 / 83 & 309 \\ -415 \text { to }-465 & \text { Mag } & 1 / 31 / 83 & 87 \\ +1 \text { to }-19 & \text { Upglac } & 7 / 18 / 83 & 336 \\ -220 \text { to }-260 & \text { Mag } & 6 / 6 / 83 & 152 \\ -4 \text { to }-24 & \text { Upglac } & 7 / 18 / 83 & 352 \\ -234 \text { to }-274 & \text { Mag } & 7 / 18 / 83 & 180 \\ -268 \text { to }-328 & \text { Mag } & 6 / 6 / 83 & 94 \\ -367 \text { to }-407 & \text { Mag } & 3 / 28 / 83 & 139 \\ -65 \text { to }-105 & \text { Mag } & 1 / 31 / 83 & 132 \\ -300 \text { to }-340 & \text { Mag } & 1 / 24 / 83 & 143\end{array}$

$\begin{array}{rrr}297 & 5.6 & -- \\ 308 & 5.9 & -- \\ 286 & 5.7 & -- \\ 420 & 5.8 & -- \\ 48 & 5.2 & -- \\ 410 & 5.8 & -- \\ 121 & 5.4 & -- \\ 204 & 5.5 & -- \\ 63 & 5.2 & -- \\ 226 & 5.6 & -- \\ 213 & 5.8 & -- \\ 308 & 6.0 & -- \\ 87 & 5.3 & -- \\ 336 & 7.1 & -- \\ 152 & 5.5 & -- \\ 352 & 7.1 & -- \\ 180 & 5.6 & -- \\ 94 & 6.2 & -- \\ 139 & 5.5 & -- \\ 132 & 5.8 & -- \\ 143 & 5.8 & --\end{array}$

$\begin{array}{rr}10 & 3.5 \\ <5 & .7 \\ <5 & .6 \\ <5 & .6 \\ <5 & .5 \\ <5 & .6 \\ <5 & .6 \\ <5 & .4 \\ <5 & .5 \\ <5 & .2 \\ <5 & .3 \\ <5 & .4 \\ <5 & .4 \\ <5 & 2.6 \\ <5 & 2.8 \\ 30 & 16 \\ <5 & 2.9 \\ <5 & 1.0 \\ <5 & .6 \\ <5 & .4 \\ <5 & .4\end{array}$

$\begin{array}{rcl}80 & 18 & 8.3 \\ 98 & 31 & 4.9 \\ 61 & 18 & 3.4 \\ 130 & 32 & 10 \\ 12 & 4 . & -- \\ 96 & 31 & 4.3 \\ 14 & 4 . & 1.0 \\ 52 & 15 & 3.4 \\ 14 & 4 . & 1.0 \\ 58 & 16 & 3.9 \\ 59 & 16 & 4.4 \\ 90 & 25 & 6.6 \\ 26 & 8 . & 1.5 \\ 61 & 17 & 4.4 \\ 44 & 10 & 4.1 \\ 59 & 18 & 3.4 \\ 49 & 14 & 2.9 \\ 27 & 6 . & 2.4 \\ 36 & 8 . & 3.4 \\ 31 & 8 . & 2.7 \\ 24 & 6.4 & 1.9\end{array}$

\begin{tabular}{ccc}
$\begin{array}{c}\text { Sell } \\
\text { no }\end{array}$ & $\begin{array}{c}\text { Sodium, } \\
\text { total } \\
\text { (mg/L } \\
\text { as Na) }\end{array}$ & $\begin{array}{c}\text { Pota } \\
\text { sium } \\
\text { tota } \\
\text { as K }\end{array}$ \\
\hline N 13 & 14 & -- \\
N 14 & 19 & -- \\
N 17 & 25 & -- \\
N 693 & 30 & -- \\
N1958 & 3.2 & - \\
N2115 & 28 & -- \\
N2413 & 5.6 & - \\
N2414 & 12 & -- \\
N3720 & 4.6 & - \\
N4077 & 16 & -- \\
N4298 & 16 & -- \\
N4390 & 19 & -- \\
N4512 & 5.8 & - \\
N5155 & 44 & -- \\
N5156 & 10 & -- \\
N6744 & 79 & -- \\
N6745 & 10 & -- \\
N7445 & 5.7 & -- \\
N7482 & 8.4 & -- \\
N7649 & 7.7 & -- \\
N7650 & 7.6 & --
\end{tabular}

Alka- Sulfate, Chloride, Fluo-
linity dis-
dis-

Total Nitrogen, Nitrogen,

otas- Iinity dis- dis- ride, dis- as nitrate, as ammonia, Arsenic, Cadmium,

K) (aCO3) as SO4) as Cl) as F)

$\left(\begin{array}{l}\mu g / L \\ \text { as } N)\end{array}\right.$

as As) ( $)$

$\begin{array}{lcc}-- & 13 & 63 \\ -- & 26 & 43 \\ -- & 14 & 28 \\ -- & 22 & 57 \\ -- & 6 . & \\ -- & 36 & 42 \\ -- & 8 . & 24 \\ -- & 18 & 3 \\ -- & 16 . & 12 \\ -- & 14 & 25 \\ -- & 39 & 30 \\ -- & 6 . & 19 \\ -- & 62 & 36 \\ -- & 15 & 21 \\ -- & 19 & 38 \\ -- & 21 & \\ -- & 25 & 27 \\ -- & 10 & \\ -- & 10 & \end{array}$

63
43
28
57
6
42
24
33
12
24
25
30
19
36
21
38
24
4
27
6
6

$\begin{array}{rc}18 & <.05 \\ 26 & .06 \\ 40 & <.05 \\ 48 & <.05 \\ 3 . & <.05 \\ 56 & <.05 \\ 8 . & .06 \\ 16 & <.05 \\ 3 . & <.05 \\ 25 & .1 \\ 26 & <.05 \\ 35 & <.05 \\ 9 . & <.05 \\ 24 & .1 \\ 22 & <.05 \\ 31 & .1 \\ 18 & <.05 \\ 8 . & <.05 \\ 11 & .07 \\ 10 & <.05 \\ 14 & <.05\end{array}$

$\begin{array}{cc}158 & 2.0 \\ 227 & 7.2 \\ 178 & 5.8 \\ 266 & 8.8 \\ 34 & <.1 \\ 242 & 5.6 \\ 62 & .4 \\ 142 & 4.1 \\ 46 & .1 \\ 104 & 3.7 \\ 144 & 4.2 \\ 206 & 3.4 \\ 52 & <.1 \\ 246 & 6.4 \\ 110 & 2.5 \\ 72 & 6.4 \\ 104 & 3.6 \\ 68 & 1.7 \\ 80 & <.1 \\ 86 & 3.6 \\ 76 & 4.6\end{array}$

$<.02$
$<.02$
$<.02$
$<.02$
$<.02$
$<.02$
$<.02$
.03
$<.02$
$<.02$
$<.02$
$<.02$
$<.02$
$<.02$
$<.02$
$<.02$
$<.02$
$<.02$
.08
.-
$<.02$

$\begin{array}{ll}<2 & <1 \\ <2 & <1 \\ <2 & <1 \\ <2 & <1 \\ <2 & <1 \\ <2 & <1 \\ <2 & <1 \\ <2 & <1 \\ <2 & <1 \\ <2 & <1 \\ <2 & <1 \\ <2 & <1 \\ <2 & <1 \\ <2 & <1 \\ <2 & <1 \\ 6 & <1 \\ <2 & <1 \\ <2 & <1 \\ <2 & <1 \\ <2 & <1 \\ <2 & <1\end{array}$


Table 11.--selected chemical analyses of ground water sampled from public-supply wells in Kings, Oueens, and enstern Nassau Count les (sampled and analyzed by Jamaica Water Supply Company) (cont Inued)

\begin{tabular}{|c|c|c|c|c|c|c|c|c|c|}
\hline $\begin{array}{l}\text { Well } \\
\text { no. }\end{array}$ & $\begin{array}{l}\text { Chromium, } \\
\text { total } \\
\text { D }{ }^{\prime} / L / L \\
\text { as Cr) }\end{array}$ & $\begin{array}{l}\text { Copper, } \\
\text { total } \\
(\mu g / L \\
\text { as Cu) }\end{array}$ & $\begin{array}{l}\text { Iron, } \\
\text { total } \\
(\mu \mathrm{g} / \mathrm{L} \\
\text { as } \mathrm{Fe})\end{array}$ & $\begin{array}{l}\text { Lead, } \\
\text { total } \\
(\mu \mathrm{g} / \mathrm{L} \\
\text { as } \mathrm{Pb})\end{array}$ & $\begin{array}{l}\text { Manganese } \\
\text { total } \\
(\mu \mathrm{g} / \mathrm{L} \\
\text { as } \mathrm{Mn})\end{array}$ & $\begin{array}{l}\text { Mercury, } \\
\text { total } \\
\text { ( } \mu \mathrm{g} / \mathrm{L} \\
\text { as Hg) }\end{array}$ & $\begin{array}{l}\text { Selentum, } \\
\text { total } \\
\mu \mathrm{g} / \mathrm{L} \\
\text { as } \mathrm{Se} \text { ) }\end{array}$ & $\begin{array}{l}\text { S1lver, } \\
\text { total } \\
\text { ( } \mu g / \mathrm{L} \\
\text { as Ag) }\end{array}$ & $\begin{array}{l}\text { Zinc, } \\
\text { total } \\
\text { ( } \mu g / L \\
\text { as } 2 n \text { ) }\end{array}$ \\
\hline N 13 & $<20$ & 20 & 140 & $<2$ & $<20$ & $<.5$ & $<2$ & $<20$ & $<20$ \\
\hline N 14 & $<20$ & 30 & 20 & $<2$ & $<20$ & $<.5$ & $<2$ & $<20$ & $<20$ \\
\hline N 17 & $<20$ & 30 & 40 & $<2$ & $<20$ & $<.5$ & $<2$ & $<20$ & $<20$ \\
\hline N 693 & $<20$ & 20 & 20 & $<2$ & $<20$ & $<.5$ & $<2$ & $<20$ & $<20$ \\
\hline N1958 & $<20$ & 20 & 20 & $<2$ & $<20$ & $<.5$ & $<2$ & $<20$ & 40 \\
\hline N2115 & $<20$ & 20 & 20 & $<2$ & 60 & $<.5$ & $<2$ & $<20$ & $<20$ \\
\hline N2413 & $<20$ & 20 & 350 & $<2$ & 30 & $<.5$ & $<2$ & $<20$ & $<20$ \\
\hline N2414 & $<20$ & 20 & 20 & $<2$ & $<20$ & $<.5$ & $<2$ & $<20$ & $<20$ \\
\hline N3720 & $<20$ & 20 & 180 & $<2$ & 20 & $<.5$ & $<2$ & $<20$ & $<20$ \\
\hline N4077 & $<20$ & 170 & 20 & 3 & $<20$ & $<.5$ & $<2$ & $<20$ & $<20$ \\
\hline N4298 & $<20$ & 20 & 20 & 2 & $<20$ & $<.5$ & $<2$ & $<20$ & $<20$ \\
\hline N4390 & $<20$ & 20 & 20 & 2 & $<20$ & $<.5$ & $<2$ & $<20$ & $<20$ \\
\hline N4512 & $<20$ & 20 & 430 & $<2$ & $<20$ & $<.5$ & $<2$ & $<20$ & $<20$ \\
\hline N5155 & $<20$ & 40 & 30 & $<2$ & $<20$ & $<.5$ & $<2$ & $<20$ & $<20$ \\
\hline N5156 & $<20$ & 20 & 20 & $<2$ & 30 & $<.5$ & $<2$ & $<20$ & - \\
\hline N6744 & $<20$ & 20 & 30 & $<2$ & $<20$ & $<.5$ & $<2$ & $<20$ & $<20$ \\
\hline N6745 & $<20$ & 30 & 20 & $<2$ & $<20$ & $<.5$ & $<2$ & $<20$ & $<20$ \\
\hline N7445 & $<20$ & 20 & 20 & $<2$ & $<20$ & $<.5$ & $<2$ & $<20$ & $<20$ \\
\hline N74882 & $<20$ & 20 & 190 & $<2$ & 60 & $<.5$ & $<2$ & $<20$ & $<20$ \\
\hline N7649 & $<20$ & 20 & 20 & $<2$ & $<20$ & $<.5$ & $<2$ & $<20$ & $<20$ \\
\hline N7650 & $<20$ & 20 & 20 & $<2$ & $<20$ & $<.5$ & $<2$ & $<20$ & $<20$ \\
\hline
\end{tabular}




